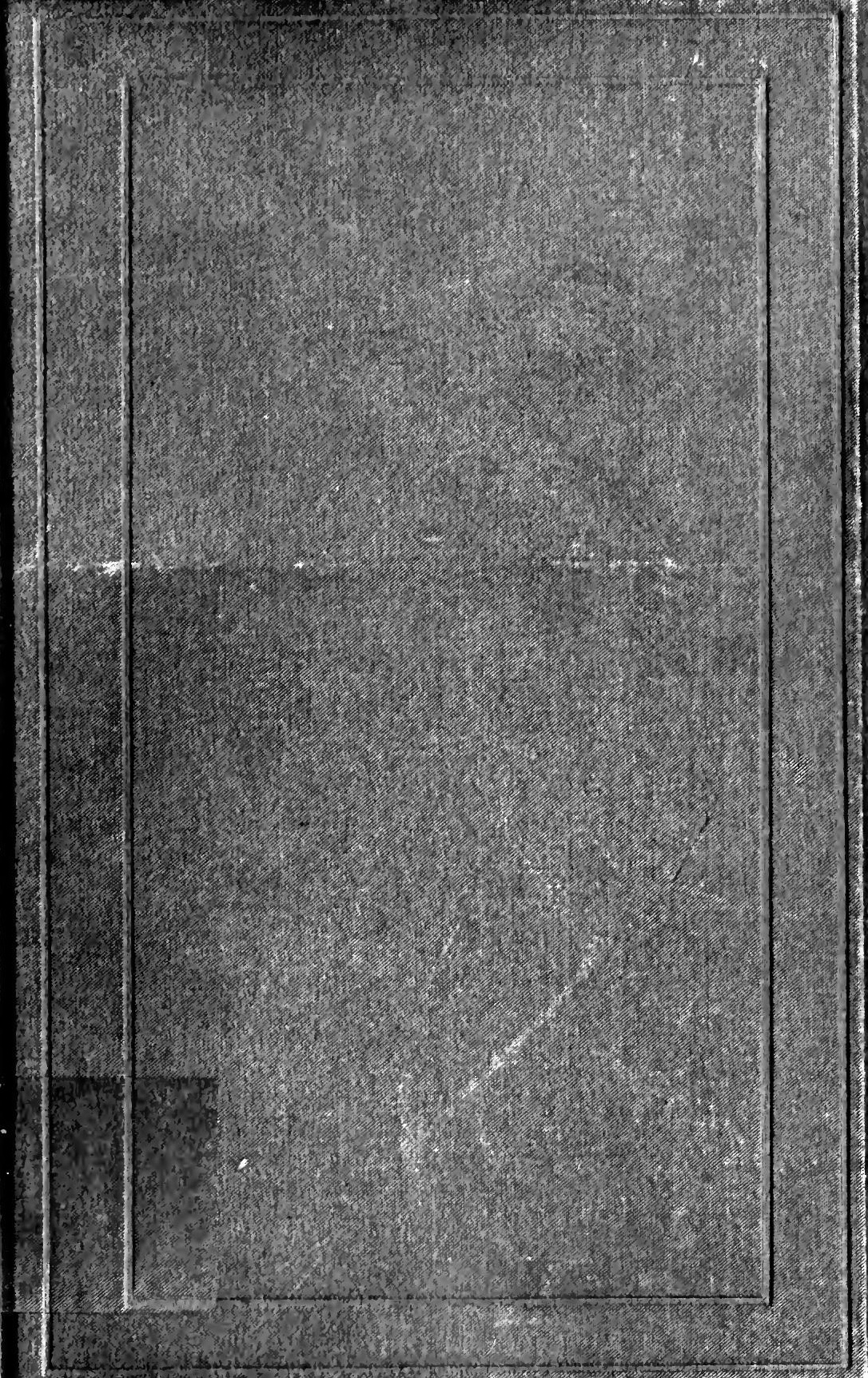




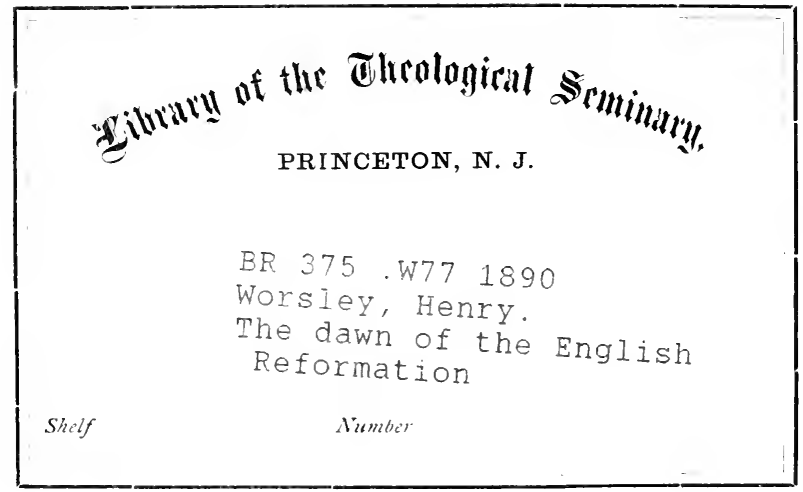




THE

DAWN OF THE ENGLISH REFORMATION. 



\section{TH E D A W N}

OF THE

\section{ENGLISH REFORMATION :}

ITS FRIENDS AND FOES.

BY

H E N R Y W O R S E Y, M.A.,

Vicar of Ashforl Bowdler.

LONDON :

ELLIOT STOCK, 62, PATERNOSTER ROW, EC. 1890. 



\section{To \\ MRS. CAROLINE TARRATT,}

OF

SUFFOLK HALL, CHELTENHAM,

TIIE KINDEST AND MOST CONSIDERATE OF FRIENIS,

and thUS a GentLe CRItic,

THESE BIOGRAPHIES

OF THE MOST IMPORTANT EPOCH IN ENGLISH HISTORY,

With THE UTMOST ESTEEM AND GRATITUDE,

Are Enstribed. 



\section{P R E F A C E.}

THIs story of the Early English Reformation, biographically told, is partly in continuation of a plan formed now some years ago, and commenced by the biography of Martin Luther. The great Saxon reformer occupied among his German fellowcountrymen a position similar to that which was occupied by Zuingli and Calvin successively among the Swiss. These theologians, gifted with large mental capacity, and living amongst those who looked up to them for instruction and guidance, exerted and maintained an authority to which it is in vain to seek a parallel in the religious development of England at the period of the Reformation.

The English Reformation was not marked by the striking ascendency of any one individual. Bilney, 'the first framer of Cambridge in the knowledge of Christ,' as Foxe describes him, was the spiritual father of many who embraced a more Scriptural creed. He was the means of converting, besides others, Hugh Latimer; and he was probably a source, at least of valuable assistance, to Tyndale. But 'little Bilney's ' warm heart was always much in advance of his somewhat clouded head. The most conspicuous figure in the ranks of the early English Reformers was Tyndale-the successful translator of Scripture, the author of the most useful religious tracts of the time, and the spiritual father of John Fryth. Inferior to none as a Christian hero, hedid not possess the great powers or exalted 
influence of the chief Continental reformers. He lived and laboured in compulsory exile from his own country. The career of Fryth was cut short at its highest promise by his martyrdom-an event, however, of infinite moment to the cause, at a crisis of hesitancy and danger. The consistent intrepidity of Latimer, only matured after some years of spiritual progress and experience, belongs to a later date.

Thus it has been judged most consonant to the genius of the English Reformation-in some important respects its peculiarly happy genius-instead of detailing the career of one individual, to interweave a series of biographies of the principal actors and writers in connection with that great religious and social revolution; not neglecting to portray its virulent and able opponents, as well as the zealous champions of the movement. By this means the Reformation will be made the centre-as no doubt in real fact it was-of the stirring historical events of that memorable epoch whence modern history takes its rise.

The history of the religious struggle aftords some insight into the condition of all ranks of society at a momentous crisis, the lowest as well as the highest. The English Reformation leavened with its influence the whole social structure. But its earliest partisans and sturdiest advocates issued from the obscure walks of life. Wealthy landowners, courtiers, statesmen, were concerned rather with the outward changes, the development into legal cnactments, of the results of the new vital principles which had gained acceptance; but these prineiples themselves were cherished and diffused chiefly by men and women belonging to the humbler grades. From such adherents to truth, too often down-trodden, despised and persecuted, the regeneration of society proceeded primarily; and only secondarily from thrones, convocations, and senates. In all ages the Word of God, under Divine guidance, has been near the root of all that is best in human progress; 
but such was signally and manifestly the case at the era of the Reformation.

The biographical treatment of the subject is in accordance with the mode in which the Almighty Himself is generally pleased to carry out His designs on the great theatre of human life. Individuals raised up by God from time to time, and educated by His Providence to their appointed task, proclaim the truths they are commissioned to teach, and animate and train their contemporaries, inspiring them with their own convictions; and thus stamp their impress, first on their own day, and then on posterity. History shows this by numerous examples, both in ancient and modern times. But especially does this rule hold good as regards religious systems, and the results which follow from them.

Moreover, such a method of individual treatment is after the highest model-the literary precedent of the Inspired Volume itself. The sacred account of the vicissitudes and progress of the chosen race, the germ and centre of true religion for the whole globe, starts with the personal careers of Abraham, Jacob and Joseph. Subsequently Moses, Joshua, Samuel, and other appointed instruments take their places conspicuously upon the canvas. In the New Testament the biographical element appears yet more prominently. "The Gospels,' says Archbishop Whately, ' are not merely historical, but strictly biographical.' The earliest ecclesiastical history also, the Acts of the Apostles, deals chiefly with individuals. Even after the astonishing growth and spread of Christianity in the world, which its earlier records imply chiefly by tracking individual careers, its latter pages trace with more exact detail the missionary labours of one eminent teacher.

It may be well to add that in other respects also the inspired writings are suggestive by their characteristic excellences. Not only are their pages made more emphatic by pregnant brevity and marvellous word-painting, but facts are 
never disguised, nor are characters ever misrepresented. The unvarnished plainness of truth is everywhere-truth in sovereign supremacy. The best men are depicted as they were: their infirmities not extenuated, their excellences not exaggerated. The good points - if such are far from amounting to redeeming qualities - of the worst, or most mistaken, are yet never denied, nor are they veiled in obscurity, or kept even partially out of sight.

The following pages have not been indited in any spirit of stinted attachment to our Protestant Reformation. With our Protestantism our national position of wealth, power, and influence is essentially bound up. But such a conviction, in its amplest strength, is no bar to the genuine and outspoken admiration of whatever was good and noble in the defenders of a long-established sacerdotal system, fast tottering to its fall at the touch of light and thought.

Of necessity the general history of the period has been succinctly presented to the reader-so far, at least, as its incidents have a bearing, more or less direct, upon the course of the Anglican Reformation. And here, too, in tracing the sequence of events of world-wide moment, the elucidation of personal eharacter has been uniformly kept in prominent view.

It may be explained that the letters 'P.S.' and 'C.S.' denote respectively the publications of the Parker and Camden Societies, as the letters B.M. stand for the British Museum. The State Papers have been public property for many years, and their publication does honour to the memory of Sir Robert Peel. 'To these a very important supplement has been added more recently. The initial 'B.' refers to this comprehensive series of Letters and Papers, Foreign and Domestic, of the Reign of Henry VIII., which has been published under the direction of the Master of the Rolls, on a plan originated and pursued through several volumes by the 
late Rev. J. S. Brewer, and continued since his decease by Mr. James Gairdner. For faithful authentic history these calendared letters and documents possess a value beyond price. With the collateral help of the calendar of the Spanish Letters, Despatches, and State Papers-referred to under the abbreviation 'Sp.' - and of the calendar of the Venetian State Papers and Munuscripts-referred to under the abbreviation 'Ven.'--together with other contemporary writings, they serve to throw a new, vivid and real light both on transactions and on individual character.

It has not been deemed necessary to evidence the correctness of all the statements made by citing the numbers or pages of all the passages consulted in the papers and documents mentioned. Had this been done the notes must have become inordinately lengthy. Nor has it been judged necessary always to cite other authorities - such as Foxe or Hallam, or other well-known authors-for statements that may be verified with very little pains. The notes have not been relegated to the end of the book, but placed at the foot of the page, inasmuch as they often lend force or clearness to the text.

The descriptions of places, houses, churches, etc., are for the most part the jottings down on the spot, or the reminiscences of a visit or visits of exploration.

Grateful acknowledgments are rendered to those who have kindly contributed assistance-highly appreciated alwaysoccasionally given at the cost of some time and trouble.

May the work, under God's blessing, prosper and be useful; and may the reader derive from its perusal some portion, at least, of the pleasure which its composition has afforded to the writer: 



\section{CONTENTS.}

\section{BOOK I.}

TIE NEED OF THE REFORMATION.-THE CHURCH IN THE BEGINNING OF THE SIXTEENTH CENTURY.

One-sided sacramentalism-Presumptuous sacerdotalism-A priest only a man-The Scriptures in the bondage of an ancient tongue - Made nugatory by subtleties-Moral declension-Scandalous Pontiffs-Reginald Pecock-Clerical immunities-Money compensation for clerical crimes-Clerical and lay conflict-Hunne's case-Priestly celibacy-Degeneracy of the friars-The monastic system-Pluralities and absenteeism-Venality-Papal pretensions-National safeguards-A revolution impending-The discovery of gunpowder-The invention of printing-Apparel of the period

\section{BOOK II.}

\section{PREPARATION.}

\section{I.-TIIE CLASSICAL REVIVAL AT OXFORD.}

Effects of the capture of Constantinople-Modern life opening-Influence of Greek literature-Grammar schools-Oxford Greek scholars-The old Latin Granmar-John Colet-Thomas More _Colet visits Italy_Colet and Erasmus_Colet founds St. Paul's School-Thomas Wolsey-The Trojans_John Fisher-Erasmus at Cambridge

$$
\text { II. - CAMBRIDGE GOSPELLERS. }
$$

Thomas Bilney-George Stafford-The Angustine Priory and Robert Barnes-Hugh Latimer-The Cambridge Brethren-The White Horse-Richard Bayfield_John Lambert-Bilney's self-denying labours 
The three great cardinals-Wolsey and Becket-Wolsey patronized by the court-A favourite with Prince Henry-Dean, bishop, cardinal, legate - Also lord chancellor - His appearance and gifts - His national policy - Ilis judicial improvements - His sense of Church needs-Sanguine aims-Beneficence to OxfordCardinal College-The Cambridge colony_Clerk and Dalaber -Wolsey's chief merit -

\section{BOOK III.}

\section{THE ENGLISH NEW TESTAMENT.}

\section{I. - WILLIAM TYNDALE'S PREPARATION.}

The supposed spot of his birth-Hunt's Court and the Tyndale memorial-Slimbridge probably his birthplace-His three brothers-His family Wycliffe's followers-The county of Gloucester-John de Trevisa-Tyndale at Magdalen Hall-His migration to Cambridge-His means of university maintenance --His ordination

\section{II.-TYNDALE AT LITTLE SODBURY.}

The manor-house - Its dining-hall-Sir John and Lady WalshTyndale's reason for translating Scripture-His patrons vexed by clerical complaints-The 'Enchiridion ' of Erasmus-Tyndale before the chancellor-Doctor Parker rates him finely-The familiar doctor's counsel-Tyndale defies the pope-The hubbub increases-The object of life settled-Tyndale leaves Sodbury for London

$$
\text { III.-TYNDALE IN LONDON. }
$$

Tyndale makes application to Tunstal-His rebuff a real blessingHumphrey Monmouth-Tyndale's manner of life with Monmouth-His experience of London-.The Christian Brotherhood -Wycliffe's efforts not lost-The Coleman Street congregation - John Fryth-England barred against God's Word-Tyndale driven to a Free City of the Hanse League-He sails for Hamburg -

IV.-TIIE ENGLISII NEW TESTAMENT PRINTING.

Tyndale at Hamburg-He proceeds to Wittenberg-Contemporary writers all agreed-Circumstances and Tyndale's character confirmatory-He employs the third edition of Erasmus's Testament-His helps for the work-The paramount influence of his version-William Roye-The Gospels of Matthew and Mark 
-Arrangement with Quentel-_John Cochlæus--The flight to Worms-The octavo and quarto editions.-The sailing of the ressel for England-The various editions and revisions of the work

\section{V.-THE NEW TESTAMENT EXPECTED.}

Warnings reach the King and hierarchy-The 'still Christmas'

Wolsey fully employed-Indiscretion of Gospellers-West of Ely and Latimer--Christmas Eve, 15\%5, at Cambridge-Barnes succumbs-The auto-da-fé at St. Paul's-Sequel of the Cambridge disorders - Bilney recants-George Joye escapes Latimer before Wolsey-Latimer licensed by the cardinal -

VI.-ENGLAND'S WELCOME TO IIER NEW TESTAMENT.

The Flemish clothiers-The colporteurs-Fyshe and Necton-The popular welcome of God's Word-The episcopal meeting-The burning of Christ's Testament-The bonfire furthered truthEpiscopal injunctions--The royal warning-Blind old NixeMandate to seize Roye and Tyndale-More's pen in requestThe persecution of 152s-Maitland's strictures on the Puritan writers-Honey Lane Church and its Parson-Garratt visits Oxford-Cardinal College 'Testament distributors-Dalaber and Garratt-The three heads of colleges-Prior Dunstan-Dalaber's troubles-Astrology at fault-Garratt apprehended-Higdon and Longland suggest mercy-Wolsey unrelenting-Clerk's death-The commiseration of the townspeople--The future careers of some of those spared-God against the popish hierarchy

VII.-THE 'WICKED MAMMON' AND THE 'OBEDIENCE.'

Tyndale and Roye separate-Jerome Barlow-The 'Burying of the Mass'-'Railing rhymes'-Tyndale at Marburg-The Landgrave's university-The 'Wicked Mammon'-Tyndale deeply influenced by Luther-The sum of Christianity-The 'True Obedience of a Christian Man'-The 'passive obedience' of Tyndale and the age-Change anticipated-Anne Boleyn and the 'Obedience'-John Fryth joins Tyndale-Amendment of their Eucharistic views-More's statement incorrect-The Marburg Conference

VII.-MORE, IIIS FAMILY AND MANOR-IIOLSE.

The two champions - Chelsea manor-house - Sir Thomas and his family

IX.-MORE'S EARLY AND LATER OPINIONS.

The 'Utopia' - More's advanced speculations - His religious opinions change-More and Luther compared-The cause célcbre - Collateral influences-More as a judge-His bitterness against 
heretics - His self-defence - Its omissions - Yet More gentler than many others

\section{X.-THE CONTROVERSY.}

The 'Dialogue'-More on Tyndale's version-His suggestions for an Anthorized Version-Tyndale's 'Answer'-Opposed definitions of the 'Church'-Tyndale's ' juggling terms'-Our reeent Revised Version - More's 'Confutation' - More and Tyndale compared as writers-Chelsea Old Church-More's cenotaphThe acerbity of religious differences-Tyndale's monuments and monument

\section{BOOK IV.}

\section{SEPARATION FROM ROME.}

\section{I.-ExGlaND's Foreign Relations.}

God's providence in behalf of England-The marriage of Arthur and Katharine-Arthur's decease-Isabella's fears-The dispensation granted-Prince Henry-Henry married to Katharine -Domestic bereavements - Henry's military ambition - The Holy League-Peace with France-Mary Tudor, bride to Louis XII.-The many erowns of Charles-Francis and Charles rivals-Wolsey's policy-Charles wins Henry and Wolsey-Henry's book-Wolsey trieked by Charles-Great danger of Francis-Bourbon's failure-The audacity of Franeis-Secret negotiations-Francis made prisoner at Pavia-Charles revealed in success - Seizure of De Praet's clespatekes - Wolsey and Charles-The emperor's magnificent prospects-The 'amieable loan'-Charles declines the Princess Mary-Wolsey draws nearer to Franee-The Italian League-The true portrait of Francis - The fraternal alliance - The motives of the new brothers-The French allianee unpopular in England-The sack of Rome-Clement's flight-The imperial troops in their success without generals-The emperor's protestations-War declared by the allied sovereigns

\section{II.-THE KING'S CONSCIENCE.}

Wolsey's embassy into France-Its objects-His brilliant train--His instructions to his followers - His glory overeast-Henry's matrimonial scruples-Wolsey's crafty solicitations-The question submitted to authorities-The origin of the king's scruples - Henry's yearning for a male successor-Anne's person and antecedents - IIenry's love-letters - Wolsey's opposition surmounted-Clement released-Kunght's confidential missionWolsey resumes negotiations with Clement-The 'Commission' drawn up by him-The strange terms of the 'Dispensation'-- Clement's perplexity-Gardiner and Fox at Orbieto--Wolsey's 
commendation of Anne-Clement and Gardiner-The 'Dispensation' and a 'General Commission' signed-Henry separates from Katharine-The character of Anne-The character of Henry

\section{III. - PREPARATIONS FOR TIIE TRIAL.}

The new Abbess of Wilton-Wolsey's forebodings-The legate Campeggio-Sickness at court-Campeggio procrastinates Clement's policy determined by events-Henry and Katharine alike obstinate-Katharine 'confesses' to Campeggio-The interposed Brief-Katharine's demeanour censured-. Was the Brief genuine?-Reasons for believing it spurious-Clement will not openly repudiate it-Campano's mission-Rumour of Clement's death-Wolsey's unstable position-Discussions about the Brief superseded-Speed! speed!

\section{IV. - THE TRIAL.}

Henry and Katharine before the legates-A scene oft doubted proved true-Fisher courts martyrdom-Katharine's procuration-Clement and Campeggio in secret understanding-Both Legates distrusted_Was Wolsey a traitor to Henry?-The sentence of prorogation-The 'Ladies' Peace'-Its termsHenry's matrimonial hopes no brighter-The Barcelona compact-The year 1529 memorable-The advocation and suspension-Wolsey warns Clement-Campeggio departs - Roman insolence disgusts the English

\section{V. - NEW MINISTERS.}

The mysterious document-The cardinals at Grafton-Wolsey's downfall certain-Wolsey sued in the Court of King's BenchHis prudent submission-Francis endeavours his reinstatement in vain-The precautions of his enemies-Charles Suffolk-Thomas Norfolk - Stephen Gardiner - Eustace Chapuys Ecclesiastical promotions-Wolsey delivers up the seal-Retires to Esher-Henry's 'comfortable words'-Sir Thomas More chancellor-Wolsey condemned_Surrenders everything _ $\quad 2 \cdot 2$

\section{VI.-THE REFORMING PARLIAMENT.}

Parliament summoned - More's two speeches - The Reforming Parliament-The Commons' petition-The title accorded to the king-The 'Three Estates'-Fisher alone has the hardihood to defend the Church - Scanty enactments of the first session-Wolsey's impeachment-'The forty-four Articles-The impeachment in the Commons languishes - Prorogation of 
Parliament-Wolkey's legal pardon-York restored to him-

Noble traits shining through misfortunes - - - 241

VII.-TIL OBSCLLE TO TILE FIONT.

Wol:ey at Esher-Crumwell on 'Allhallowen-day'-Crumwell rides to London-His shrewdness relieves Wolsey-How Crumwell gained royal favour-His first interview with Henry-All the clergy in a præmunire-Their bargain with Henry - Crumwell's defence of Wolsey acceptable to the king-His rapid elevation - His fidelity in contrast to Gardiner-Crumwell's early lifeWas he quite ignorant of Latin?-The Italy of that ageCrumwell's career of prosperity-Gardiner and Fox meet Cranmer-Cranmer's suggestion-He is sent for by HenryWas Cranmer Lord Rochford's priest?.- The embassy to Bologna-Cranmer at Rome-Cranmer ambassador to Charles - He is suddenly recalled-His reluctance to obey-He is consecrated archbishop-Cranmer and Crumwell-Their differences and agreements in character

\section{VII. -TIE CHOWN ANII THE TIARA.}

Henry reluctant to break with Clement-Henry's embarrassmentsThe first papal Brief-Delay extorted-University sentencesVenality rife-Delays again-Henry indignantly refuses to be tried at Rome-His letter to Clement-Katharine's requests conceded by the pope-The second papal Brief-The king's citation a national insult-An 'Excusator' sent-Who is not admitted-English pride wounded-The vehement struggle throughout England-Pulpit controversy - The Greenwich sermons-The Nun of Kent--Fruitless efforts with Katharine(iod's watchful providence

$$
\text { IX. -THE CONFLICT DIAWING TO AN END. }
$$

The third papal Brief-Its influence neutralized-Cranmer's elevation encourages Henry-He secretly marries Anne-The archbishop's court at Dunstable-Cranmer gives sentence-The coronation-Katharine will not relinquish her title-Henry prepares for the concluding struggle-The royal supremacyThe Speaker of the Commons summoned-The Act in restraint of amnates-The submission of the clergy-More's resignation -Audley keeper of the seal-More and Fisher-Spain and England contrasted : formerly and now-The obvious lesson - 2!1

$$
\text { X.-TIE FINAL SEVERANGE. }
$$

The Statute of Appeals-Henry excommunicated-Clement and Francis at Marseilles-Bonner presents Henry's appeal-The 
marriage with Katharine declared valid at Rome-The Act of Settlement-The Act of Royal Supremacy-Birth and baptism of Elizabeth -

\section{BOOK V.}

\section{MARTYR CONSTANCY.}

\section{I.-ONe condition to success Wantini.}

Three conditions necessary to success-Heroic constancy still wanting-Tyndale on the divorce question-His right of private judgment-His interpretation of events in England-- $\mathrm{He}$ removes from Marburg-The Packington bargain-The version of the Pentateuch-Jonah and its Prologue-The text at last found-The Treaty of Cambray-The king's May meetingThe proclamation

$$
\text { II.-HEGill LATIMER. }
$$

Latimer's pulpit warfare-His noble letter to Henry for an open Bible-His labours at West Kington-Latimer as a preacherHe is tried, and fails-Scene in the Arras Chamber-Persecution triumphant-Crome yields-Latimer with Bainham -

\section{III.-AN EFFORT TO REPAIR FAILURE.}

Bilney's shame for his recantation-His repentance and revived courage-His martyrdom

$$
\text { IV.-THE SEAL OF SUCCESS. }
$$

Tyndale the chief stay among our early Reformers-Vaughan commissioned to draw him to England-Letters and interviewsElyot's endeavours also in vain-Antwerp, and Tyndale's life there-Fryth returns to England-More aroused by Fryth's explanation of the Eucharist-Fryth apprehended-He is placed in the Tower-Tyndale's first epistle to Fryth-Frytl's treatment less severe-More's letter in reply to Fryth's explanation -Fryth's important answer to More-The plain offer of Fryth and Tyndale-Tyudale's second epistle to Fryth-Tyndale enters the Eucharistic controversy-His 'Supper of the Lord' -More's answer to Tyndale-Curwen's sermon-Fryth tried and condemned-...Fryth's unfaltering heroism-Fryth and Hewet burned-The New Act of Parliament_Fryth's constancy sealed the success of our Reformation-Tyndale and Fryth the heroes of its early stage--Their permanent memorials still with us - 331 


\section{BOOK VI.}

MEDIEVALISI PASSING.- WOLSEY'S LAST MAIS.

Wolsey removes from Esher to Richmond-His progress to his northern see-He becomes a model bishop-His zealous dis. charge of his duties-From Southwell he removes to ScroobyThence he journeys to Cawood-He resolves to walk to the Minster barefoot-His popularity alarms his rivals-Their accusations against bim- $\mathrm{H}$ is arrest determined on-Walshe and Northumberland at Cawood-Wolsey surrenders to WalsheHis abject despondency-The journey begun to London-The delay at Sheffield Park-Kingston arrives with the Guards-The cardinal's superstition - Leicester Abbey r'eached-Wolsey's last hours-His death and burial-A system interred with him 
THE

\section{D.IWX OF THE ENGLISH REFORULTIOX.}

\section{BOOK I.}

THE NEED OF THE REFORIATION.-THE CHURCH IN THE BEGINNING OF THE SINTEENTH CENTURY.

THe design of the Reformation, in Burnet's words, was 'to restore (hristianity to what it was at first, and to purge it of those corruptions with which it was overrun in the later and darker ages.' No age was darker, at least morally, than that which immediately preceded the Reformation: the darkest hour was just before the new dawn. Corruption of doctrine and eorruption of life had acted and reaeted with aggravating influence on one another; the circumstances of the times had contributed to augment evils; and the result was appalling, as is allowed, without dispute, on all sides.

A brief account of the condition of the Church in the opening years of the sixteenth eentury may serve to show the imperative need of the Reformation, as regards both doctrine and manners.

The dogma that Christ, Divine and human, is aetually present in the Eucharist, after eonsecration, in the elements themselves, although of comparatively recent introduetion, had eome to be accepted as of the very essence of the faith.

Although eontradictory to reason, and opposed to sicripture, this doctrinal imnovation, gradually gaining ground-fo-tered, no doubt, by unguarded enthusiastie expressions in muchadmired hymns-now held the central place in the Church system. 
The teaching prevailed generally that the merits of Christ are applied chiefly, or even exclusively, through the sacraments. And the outward act of sacramental reception was too often regarded as all-sufticient, the necessity of repentance and faith being overlooked. Thus religion, robbed of its true life and spirit, was degraded into a decent formalism -a merely objective system of outside observances.

Sacramental views, thus fatal to the life of piety, were in strict accordance with that arrogant sacerdotalism which had superseded the primitive institution of the Christian ministry.* The Divine Head had founded His Church upon the model of a family-the twelve Apostles corresponding to Jacob's sons, the twelve Patriarchs. The twelve Christian Patriarchs, under the guidance of Divine illumination, according to the exigencies of circumstances, direeted and developed the progress and the system of 'the household of faith.' But the Roman ('hurch had contravened the I)ivine Founder's plan, and had drawn a clear and strong line of demareation between the clergy and the laity. The idea of the Church became thus narrowed in general conception to the clergy alone.

There was another infringement of primitive institutions in the rule of priestly celibacy. This is contrary to the plain text of Sicripture; to Apostolic precedent; and to the custom of ecclesiastics in early times, $\dagger$ as well as to nature itself. But it had been zealously enforced by Gregory VII. (Hildebrand), a second Dunstan, with ampler powers, and wider influence. And thus the dividing gulf between clergy and laity became widened. The elergy were isolated like a caste, at the same time that they were precluded from becoming an hereditary caste. The pride of the heart was thus intensely flattered; and before long sacerdotal pretensions reached a portentous height. The priest trenched upon the inalienalle prerogatives of the one Divine Priest. 'The merely human priest invaded the office of the one Mediator; he claimed to be the appointed link between the Creator and His

* The lamented, learned, and able Dr. Lightfoot, Bishop of Durham, has clearly shown that sucerdotulism is unsupported by Scripture. See his. 'Dissertation on the Christian Ministry' appended to his 'Commentary on the Epistle to the Philippians.'

+ See Milman's' Lat. C'hrist,', iv., p. 17, etc. 
erring creatures. As such, the merely human priest conferred the Holy Ghost in baptism, and made his Maker in the sacrifice of the Mass. He listened to the acknowledgment of $\sin$ in act or word, or even motive and thought, from the trembling lips of the matron and the maiden, in the unapproached secrecy of the confessional. It was his to sound the mysterious depths of the conscience. He delivered his authoritative censures; imposed penalties; and absolved from guilt. The keys of the invisible world were in his privileged and tenacious grasp.

To prerogatives so exaggerated, it was no feeble support that the learning of the age, and even too frequently the mere ability to read and write, were almost restricted to the sacerdotal order. It is true that our Anglican Church-for she was termed 'Anglican' in our. Hagna Churta-was less submissive to the Papacy than the Church in most other countries. The spirit of vigorous nationality, which not seldom animated the king and the baron, sometimes found a response even in the breasts of ecclesiastics. But for the most part the priest belonged to his order rather than to his nation. He did not fail commonly to assert to the full the supposed right of his privileged order and his sacred office, and exercised an authority over the individual, the family, and the district, similar to that which St. leter's infallible successor claimed over kings and kingdoms.

But to exercise authority so exalted, and discharge functions so stupendous, without abuse, demanded nothing less than angelic purity. Considering the infirmities of human nature, it is no marvel that the weak credulity of the laity lured on the priesthood to greater and greater presumption. Contempt for the easily deluded multitude led to profaneness and irreverence towards God Himself and the mysteries of the Christian faith. Thus Luther, when he was at Rome (1510), overheard the priests venting their mock of lay superstition, and muttering in the Mass instead of the solemn words of consecration, their own ribald blasphemy- Bread thou art, and bread thou shalt remain; wine thou art, and wine thou shalt remain.'

That the priest might retain exclusively the post-which he 
so often abused to evil, and degraded by personal vice-of spiritual guide and director, ecelesiastical antipathy was outspoken and vehement against any project to translate the sacred Scriptures into a modern tongue "understanded of the people.' The antipathy developed into overt prolibition of such translation. This was chiefly in order to keep the lay mind in the one orthodox groove, and to prevent the floodgates of heresy from being thrown wide open by the exercise of thought. 'The Jivine warning' was eited against throwing pearls before swine.

But this was by no means all. The school-doetors had devised a complicated system of interpretation, which rendered the text of the learned languages of the inspired books only the hard outside shell to difficulties deeper and more perplexing. Thus one monopoly had been fortified by another monopoly. Contemporary lrotestant writers are profuse of metaphor in describing the impediments wherewith the Church had hampered the meaning of the plain words of the plainest of all teachers. The strait gate and narrow way had been blocked with prickly thorns. The cobwebs of blinding glosses had been spread by 'poisoned spiders' over luminous texts. The stream of Divine truth, so limpid in the Seriptures themselves for every thirsty soul to drink, had been made muddy by a melley of subtleties and a jargon of a jugghing terms.' And thus Erasmus, in publishing the text of the Greek Testament, with a simple Latin version, in parallel columns, spoke of himself as opening again-as Tyndale delighted to repeat after him-the 'wells of Abraham,' which 'the Scribes and Pharisees, those wicked and spiteful Philistines, had stopped and filled up with the earth of their false expositions.'

As regards the eonnected department of morals, there ean he no question that, just before the erisis of the Reformation, the habits and moral condition of the whole ecelesiastical corporation-seeular, regular, and mendieant-had beeome worse than probably at any period before, or in fact since. In Freeman's words, not only were the Parliaments of the tifteenth century in England 'less liberal and independent bodies than those of the fourteenth,' but 'the Chureh of the fifteenth cen- 
tury was scandalously corrupt."* The moral state of socicty generally had detcriorated likewise, by natural consequence. Discipline had grown lax. 'Men, spiritual and regular,' it was complained, 'observe no rule.' 'No priest,' it was commonly said, 'is meek, no monk poor, no friar chaste.'

The inferior clergy could plead in mitigation of censure the debased example of those in the highest ecclesiastical stations. Here the condition of things was so foul as to mock at the most anxious eftorts of reform. The Great Schism itself (1378), which lasted nearly forty years, had been even accelerated by high-handed attempts on the part of Urban VI. to bring about moral amendment. After a time the characters of both the rival pontift's, Urban and Clement VII.-who excommunicated and damned one another - proved so thoroughly Antichristian, that Wycliffe pronounced their lives to have "nothing in common with the holy (hurch of God,' which would be 'in better ease without either of them.' Worse followed. Just before and after the beginning of the sixteenth century, the pontiffs were mere secular princes, using spiritual pretensions, sometimes for the temporal benefit of their see, more frequently for family or personal aggrandizement. Councils were summoned, to essay the herculean task of cleansing the Church, but withont any avail.

As regards the moral characters of the pontiffs, Innocent VIII. (1+\$t) was the father of seven children by as many different women. Under him, everything was venal. Alexander VI. (1492) was guilty of almost every foul deed in the catalogue of depravity. His son, the diminutive and lithe Ciesar Borgia, his daughter Lucretia, were as infamous as their father, and never scrupled to employ the poniard or the poison-bowl. Then, after the twenty-six days' pontificate of Pius III., came (1503) Julius II. Addicted to wine, libidinous in earlier life, in his later career he proved more patriotic than his immediate predecessors. A bearded warrior, the most characteristic passage in his reign was his entering Mirandola (January, 1511) through a breach in the walls, in heimet and cuirass. The prodigal Leo $\mathrm{X}$., the pupil of Politian, the

$$
\text { * 'Historical Essays,' i., pp. 47, } 49 \text {. }
$$


patron of Raffaello and of Ariosto, succeeded (Narch, 1513) when only thirty-seven years of age.

In the fifth century Leo I., sometimes styled 'the Great,' had laboured with success to adrance the pretensions and power of the Roman See. Much later, but four hundred and fifty years before the beginning of the sixteenth century, Leo IX. (Bruno), previously Bishop of Toul, had administered ecelesiastical aftairs with energy, and had been a sharp reprover of the filthy crimes, whether according to nature or below nature, which degraded the monks. It was barefoot, in mean attire, that Bruno had entered Rome as a pilgrim (1049), with Hildebrand, his Mentor, at his side, to seek the ratification from the clergy and people of his appointment by his imperial cousin, Henry III., to St. Peter's chair. A pontiff of sinilar character seemed loully called for by the present condition of the Church. And probably a scintillation of this truth, together with the perception that such a conviction was afloat in the world, led to the revival in the style chosen by the youthful pontitf of an honourer name. But Leo X. differed -how widely!-from Leo IX.

The successor to the warlike Julius was an intellectual voluptuary, whose tastes were shared by his court. Jike the painter who turned away from an inferior work of art lest his hand should lose some of its eumning, so Cardinal Bembo disdainerl to set eyes upon the Tulgate or Breviary, lest his own pure Latinity should eatch the un-Ciceronian taint. Other cardinals were more remarkable for their gorgeous equipages, gilded chariots, sunshades of peacock plumes, novel delicacies of eulinary retinement, and devotion to pagan art, than for their obedient submission to the precepts, or for their humble faith in the articles of ('hristian creed. Without exciting surprise, the cry was heard on all sides, and was echoed at the papal court itself, that the Church must be reformed in 'the head and the members.'

Turning to England in partieular, the elief feature of the fifteenth century was overflowing lawlessness. The Church on the Continent, in this century, was blessed, amid deep corruption, with thinkers and writers such as John of Goch (died $1+7.5)$, John of 11 esel (died in prison 1+s1), whose writings 
became text-books at Erfurth, and, greater than either, John Wessel, of Groeningen (died 1489), who, for his scientific theology, is called by Ullmann 'pre-eminently the theological forerunner of the Reformation.'* The Dominican mystics also, their contemplative piety a protest against the too merely objective religion of the Middle Ages; Tauler, whose discourses Luther highly appreciated; Eckart; and the author of the 'Imitation of Christ,' only less inimitable than the Divine Model Himself, and others, belong to this period. In England deeper darkness marked the failure of Wycliffe's efforts. Only Reginald Pecock, bishop first of St. Asaph, then of Chichester, a star of somewhat ambiguous lustre, a defender of the pope and bishops against popular odium, a 'repressor of overmuch blaming of the clergy'-the biting censures applied to them evidencing the still remaining influence of the 'Bible-men' or Lollards - yet a penetrating critic, a student of the Scriptures, an advocate of toleration and of the marriage of priests, illumines the waste of dulness and blackness. So little, notwithstanding his exculpatory book, was Pecock acceptable to the clergy, that he was condemned in a synod at Lambeth (14.57) and deprived of his see. Before this, Sir John Oldcastle (by right of his wife, Lord Cobham) had been martyred (1417), and thenceforward the ascendancy of the selfish grasping hierarchy lasted into the sixteenth century.

In such an age the Church afforded more stable support than the shifting quagmires around. The kings, therefore, of the House of Lancaster, with keen-sighted wariness, made the clergy their allies in their usurpation, winked at their moral delinquencies, sanctioned laws against heretics. Subsequently the House of York found it expedient to steer in the wake of Lancaster. Thus the exemption of the clergy from trial in a secular court-under the pretence that no spiritual man ought to be tried by a worldly man, for the fifth commandment bids. 'Honour father and mother,' and Scripture instils the prohibition, 'Touch not Mine anointed '-a claim which had been for' centuries a bone of contention in law, and which long remainer such in fact, was at last conceded, when the House of Iork

* Ullmann's 'Reformers before the Reformation' (Clark's Foreign Theological Library), ii., p. 259. 
triumphed over Henry VI. This exemption was confirmed by the victor of Bosworth, when his new erown was as yet un. steady on his head.

Thus sacerdotalism received its consummation, and piety was reduced to the lowest ebb. No cleric, until he had been excommunicated, could be arraigned before a lay tribunal. Thus to have the most eriminal or flagitious act done by a member of the sacred order visited with eondign punishment became an achievement of complicated difticulty. The unrestrained sacerdotalism of the age, giving full effect to its one-sided sacramentalism, proffered temptations to the foulest vices and worst erimes by the promise of immunity hereafter, and the prospect of immunity here.

Nor was this all. Others, also, besides those properly belonging to the sacred order, found refuge under the ample folds of the sacerdotal wing. If anyone arraigned in a secular court for robbery or murder could prove his ability to read or write, he was allowed to claim 'benefit of elergy', and thus to have his cause transferred from the secular to the spiritual court. The greater lenieney of ecelesiastical sentences may be argued to have 'done much to uphold a higher' standard of humanity'; but a wide door had been thus thrown open to gross abuses. The Roman Chancery had established a graduated scale of fines, according to which by a money payment 'anointed malefactors' could eompound for flagrant transgressions. The vow of chastity might be violated for the modest sum of one hundred livres. Assassination by a bishop or abbot cost the guilty ecclesiastic three hundred livres. Absolution from murder was assessed to a deacon at twenty erowns.

The extremity of the evils thus lightly dealt with added fresh force to the demand for Church reform. In Germany, where elerical prerogative towered to its highest point, it was demanded, in the peasant insurrection, that the clergy should be tried and punished by lay judges. In England, early in the reign of Henry VIII., the claim of ecclesiastical immunity embroiled the laity with the clergy. A brief account of this remarkable dispute will not be out of place.

It had been enacted in 1513 that murderers and robbers 
should be denied the benefit of their clergy.* The House of Lords made an exception in favour of those within the holy orders of bishop, priest, or deacon. The elergy still felt aggrieved, fearing that the attack upon the lower grades would erelong be extended to the higher members of the sacred profession. The Abbot of Wincheleombe preached a violent sermon at Paul's Cross in maintenance of the exemption of all clerks, whether of lower or higher degree, in criminal cases, from eivil jurisdiction. The laity were roused on their side to extreme indignation, and the matter was brought before the king. Standish, Guardian of the Cordeliers, argued in behalf of the rights of the laity, although he well knew that he was contravening the sentiments of the bishops, and of the entire clerical body. The Abbot of Winchelcombe was 'counsel for the clergy.'

The contest was further aggravated by the affair of Richard Hunne. which happened at this particular juncture. Hunne had refused to pay the mortuary (the biering sheet) for a deceased child five years of age. For payment of this due he was sued, and in return sued the plaintiff in a promunire. Then heresy was charged against Hunne; he had been found to have in his possession Wycliffe's Bible, which was cited in proof of the allegation that he was a heretic. He was accordingly imprisoned in the Lollards' Tower at St. Paul's, and here he was found in his cell hanged and dead. The clergy maintained that he had been guilty of suicide and hanged himself. But, such a supposition was inconsistent with all that was known of Hunne's character. The coroner's verdict pronounced that Dr. Horsey, chancellor to the Bishop of London, and the bishop's sumner (summoner), and the bell-ringer, had murdered him, and then, to conceal their guilt, had hanged up his body. The bishop, on his part, proceeded against the dead body. Hunne was condemned as a heretic, and his body was burnt at Smithfield. Then the House of Commons took up the matter, and, compassionating the victim of clerical malignity, passed a Bill for the restoration of Hunne's children. The Bill was sent up to the Lords, where the power of the prelates was overwhelming. Thus Convoca* 4 Henry VIII., ii., c. ?. 
tion and the Peers became in effect arrayed against the C'ommons. The opinion of the judges was next sought, and was given against the clergy. After this, to ealm the animosity which continued to prevail amid such diverging verdiets, and was rather embittered than subdued by length of time, the opponents were summoned to appear before Henry himself at Baynard's Castle. The royal words on this occasion (April, 1515) were so eharacteristic that they sound like a prophecy of events which came to pass fifteen years afterwards: 'By the permission and ordinance of God we are King of England, and the King of England in times past never had any superior but God only. Therefore know you well that we will maintain the right of our erown, and of our temporal jurisdiction, as well in this as in all other points, in as ample manner as any of our progenitors have done before our time. And as for your decrees, we are well assured that you of the spirituality go expressly against the words of divers of them, as hath been showed you by some of our council; and you interpret your decrees at your pleasure; but we will not agree to them more than our progenitors have done in former times.'

The heat of strife was somewhat allayed by what wears the appearance of a kind of eompromise. Horsey was dismissed from his post: Standish was excluded from Convocation. But the Londoners still remained dissatisfied. The affair has been detailed with some fulness by Burnet, who adds the comment: 'It seems to have had great influence on people's minds, and to have disposed them much to the changes that followed afterwards.'*

To raise sacerdotalism to its eoveted pitch of exaltation, celibacy, introduced into England by Augustin, and cnforeed with rigour by Hildebrand, had been a cherished instrument. 'This requirement in the teeth of nature was rather for political than for moral ends. It served to draw a clear line between the clergy and the laity, and, by strengthening the unity, to increase the power of the clerical corporation. Habits of selfdenial it had less effeet in indueing. Indeed, as a matter of fact, the prescribed rule was hypoeritically dealt with-and * Nirres' liuruet's 'Reformation," part i., book i., pp. 20-30. 
that with the connivance of those in authority. The severity of compulsory celibacy was too much for average human nature; it proved often an inlet to degrading vice, and required to be mitigated extensively in general practice. Thus, among the seculars, a priest could, without any appalling difficulty, purchase a license to keep a concubine. And even that the prior of a monastery should, 'on account of fragility,' hold such a license, was not quite without precedent. In Germany the concubinage of priests was common.* In England some slur was cast upon the practice: and it was argued that to have one concubine in the house was worse than to have ten whores outside. $\dagger$

Nore than two centuries had elapsed since the great Florentine had sung of St. Francis (1210), and of St. Dominic (1215), the former' 'seraphic all in fervency, the latter radiance of cherubic light, + as the two ordained by Providence to a noble work of spiritual regeneration. But the revival of which these founders of zealous rival fraternities had been the instruments had by this time sunk from the flame of first love to the dull decay of dying embers. The period of declension may be gathered by implication from the writings of foremost ecclesiastics. The admirable Robert Grosse-tête-a prelate worthy to preside over the diocese

* Of the 'Centum Gravamina' transmitted by the Diet of Nuremberg to Adrian VI. the ninety-first complained of this licensing system. Tyndale says: "Through Dutchland every priest paying a gildren unto the archdeacon shall freely and quietly have his whore . . . as they do in Wales, in Ireland, Scotland, France, and Spain.'-Works, P.S., iii., p. 40.

$\dagger$ :Cum ob malum exemplum, tum ob occasionem sæpius peccandi cum eâ, quæe domi sit.'-Tho. Mori Apologia pro Erasmo. 'To pour,' wrote Tyndale, 'too much wine in the chalice, or read the Gospel without light, or' make not his crosses aright, how trembleth he! how feareth he! What an horrible sin is committed! I cry God mercy, saith he, and you my ghostly father! But to hold an whore or another man's wife, to buy a benefice,' etc. Again : 'When the holy Father had forbade priests their wives, the bishops permitted them whores of their own for a yearly tribute, and do still yet in all lands save in England, where they may not have any other save men's wives only.'-Works, P.s., i., pp. 2:3.2, 'ㄴ.'; ii., p. 295 ; 'Suppression of Monasteries,' C.S., pp. 47, 58 ; Erasmi, op. ix., p. 401.

$+\quad$ Tutto Seraphico in ardore,

L' altro per sapienza in terra fue

Di Cherubica luce nno splendore.'

Dante, 'Paradiso,' canto xi. 
blessed with the episcopate of St. Hugh of Lincoln thirty-five years previously - was Bishop of Lincoln 12:35. He was also Chancellor of Oxford, and is to be revered as the patron of Roger Bacon. So eminent was his piety that at his decease derout ears could hear bells in heaven ringing a peal of welcome. Grosse-tête employed the energy of the friars to supplement the insufficiency of the secular elergy. But, a century later, the honest Richard Fitz-Ralph, Archbishop of Armagh-contemporary with the anti-Pelagian Thomas Bradwardine-and after him Wycliffe in his later writings, denounced their greed of power and pelf, and their other vices. 'Lecherous ruftians' is the description whereby Froude* designates the mendicants of Wyeliffe's day. The declension continued unchecked. Friaries, numneries, monasteries, still in theory the sanctuaries of a more devoted piety-although, during the wars of the Roses, as hospitals and places of refuge, they earned many a benediction-had now become too often nests of drowsy sloth, of indolent ignorance, and even dis. reputable drunkenness and debauchery.

The monasteries, like most human institutions, have a varied record, good and cvil interspersed, the evil in their later history, no doubt, preponderating. Like other wealthy landowners of the time, the monasteries lent their aid to diffuse the blessings of education. The Benedictines, the greatest of the monastic bodies - who had alone made progress instead of suffering declension in the fifteenth century, the classical revival having stimulated their learned labourspossessed three establishments at Oxford-St. Benedict's, or Gloncester Hall, now Worcester College; Canterbury Hall, now merged in Christ Church; St. Cuthbert's Hall, now Trinity College. Besides this great fraternity, many a monastery supported one or more students at one or other of the universities, by a grant, or corrody. Religious persons there were, too, inside the cloisters, who used embroidering, writing books with very fair hand, making garments, carving, painting, engraving. Some few took an interest in scientific pursuits. Some convents, also, supplied Abbey.'

'Short Studies on Great Subjects,' vol. iii. ; 'Annals of an English 
the best ladies' schools of the age, where 'gentlemen's children were right virtuously brought up.' In too many districts such conventual establishments had now become rare spectacles of happy industry and active usefulness amidst too frequent useless torpor-verdant oases, gladdening the penetrating eye, amid what for the most part was a dreary waste.

There has been recently published by an English Benedictine a book entitled 'Henry VIII. and the English Monasteries," which professes to be an 'attempt to illustrate the history of their suppression.' The book is really an attempt to make white the sepulchre, and sweeten the odour of English medieval conventualism. This it has attempted to do, chiefly by trying to make black the reputations of the visitors of the monasteries under Crumwell-Layton, Legh, Ap Rice, and London, and especially by trying to make blacker than it even was before the reputation of Crumwell himself. It would, however, be no very difficult task to match the statements of the visitors in their letters by clear and conclusive passages from competent authorities. Without quoting from Luther and a numerous throng of other wellinformed witnesses, the testimony of Erasmus, $\uparrow$ who knew the monasteries well, and whose observations illustrate with vivid touches conventual manners and life, is itself alone sufficient. If necessary, the testimony of bishops, of kings, and of pontift's themselves, could be added without difticulty. The condemnation of conventual morality pronounced by Cruinwell and his visitors, however self-interested they may have been, is by no means singular, but in strict harmony with facts and general convictions, with the express statements, or incidental hints of the principal contemporary writers.

* By Francis Aidan Cxasquet, monk of the Order of St. Benedict (2 vols.).

$\dagger$ 'The advice of Erasmus to one who would fain be a nun may serve as a specimen: 'Videndum est,' he cautions, 'ne dum paras nubere Christo, nubas aliis.' In his 'Colloquia'-Tirgo Mró́yapos and Virgo Pernitens-it nun (Katharina) describes to Eubulus (good counsellor) her taking the veil : 'I was decked out as a bride,' she says, 'non aliter quam nuptura Christo.' To which Eubulus, aside : 'Crasso monacho; hem! male sit huic tussi !' ('Bride to a greasy monk, you mean.' Coughing, 'A plague on this cough!'). Similar passages could be cited ad libitum. Erasmus regarded the nunnery as a sphere of much temptation, and judged it safer for a girl not to know Latin. 
The records recently published of four visitations in the Diocese of Norwich about the beginning of the sixteenth century* are in some important respects much of a piece with the 'Visitors' Letters.' Here the larger houses, such as Norwich, Wymondham, Westacre, and Walsingham, were found in a very unsatisfactory state. But generally debt had resulted from over-building; the due number of University students was no longer kept up; there was a lack of grammar training in the monastrey. The nuns were more clear of flagrant charges than the monks. But, as regards both, the records furnish a melancholy picture of wasted existence; and the conciusion is confirmed that educationally and derotionally the convents had outlived their use.

Under the special requirements of remote centuries the monasteries multiplied-edifices, like the feudal castle itself, to a large extent part and parcel of medievalism-at once Church centres, retreats, hospitals, workhouses, penitentiaries, a-ylums, schools, libraries, workshops, roadside inns. To expatiate on their manifold usefulness to noble and peasant at the time when they flourished is one thing; to pretend that they were morally immaculate, or even made any distant approach to such a desirable condition-at least, towards the close of their continuance-is quite another thing. Extraordinary influences must inevitably be required to keep such institutions in the safe path of religious and moral rectitude; and such influences were generally absent. It is beyond question that the compulsory celibaey of monks, nuns, and priests, especially with the filthy confessional superadded, must always have a too apt tendency to poison the springs of domestic purity.

It was, of course, a eorollary to the national repudiation of the Papacy that the garrison forts should fall. Yet the lamentation may be permitted that an effete system should not have undergone metamorphose instead of total abolition. A unique opportunity was wasted, and sacrilege was thought light of. IV ealth, which, besides endowing fourteen bishopries, might have spread the neans of religious instruetion and sound education through the length and breadth of the land for

\footnotetext{
* Dr. Jessop's Visitations, C.S., 1888.
} 
future centuries, was abused to swell the pride of aristocratic houses, or was swept into the royal coffers, to be squandered at the gaming-table or lavished on profligate favourites. Even Latimer's well-known temperate request to Crumwell, in behalf of 'an honest man, the Prior of Great Malvern (Richard Bedyll), in my diocese-though not of my diocese, being exempt,' etc.-for ' the upstanding of his house, and continuance of the same to many good purposes; not in monkery,' but to maintain teaching, preaching, study with praying, and 'good housekeeping'-although this reasonable request was enforced by the promise of a handsome bribe both to the monarch and to his minister-was nevertheless disallowed. 'Alas! my good lord,' wrote the Protestant bishop, 'shall we not sec two or three (houses) in every shire ehanged to such remedy?' But the vultures had their beaks buried deep in the carcase, and no arguments or entreaties could draw them off from their prey.

Amongst the secular clergy the evils of pluralities and absenteeism-the former of course involving the latterabounded. Six, eight, or ten benefices would be held by one parson, who resided on none. 'Unpreaching prelates,' to quote Latimer's phrase, were the rule-by no means the exception. Such, too, were most of the bishops themselves, as well as the immense majority of the beneficed elergy. Wolsey's successor in the See of Tork (Edward Lee) could find only twelve of his clergy who were competent to preach. Absenteeism was so rife as to arouse loud complaints even in that age. 'Strawberries' Latimer named those who visited their parishes once a year. But the Word of God, he insisted, is 'meat, not strawberries, that come but once a year and tarry not long.' Benefices and ecclesiastical dignities, as regards at least the emoluments, were conferred not unfrequently on laymen, and even on minors. A system also obtained of handsome douceurs for a piece of preferment, presented not only to private, but even to public patrons, without much sense of shame or effort of concealment. Siums of money, perfumed gloves - 'well lined' - stuffed with guineas; a dish of apples-all the apples 'of one taste,' each one filled with gold pieces - a horse, a saddle, propitiated the 
patron's goodwill, and determined his preference.* Venality was a badge of the age in Church as well as State.

But, incleed, the disease was of long standing and of lofty precedent. 'The 'Vision of Piers Plowman,' written (about 1362) not in an anti-papal vein, represented 'Lady Reward' and 'Master Simony' sealing the pope's Bulls. The hand of St. Peter's successor was large enough to grasp everything. By reverections, the pope nominated, out of course, to some benefices immediately; by expectutive graces, he conferred benefices in reversion; by annates, he appropriated a year's produce of a preferment; by indulyences, the profit, ostensibly to be devoted to some plausible purpose-a war against the Turk, the building of St. Peter's, etc. - he strove to fill the vacuum which still would appear in his ever-shrinking coffers. There were those who maintained that in strict, right all Church property belonged to the pontiff; nay, that he had an inherent right to all temporal property also, and even to dispose at his will of temporal kingdoms; for had not Christ declared: "All power is given unto Me in heaven and in earth'? An earlier bishop of Rome had pronounced that he who should claim to be 'universal bishop' would be 'Antichrist'; but now the pontifical claims had advanced very much further. I'retensions so unbounded were enough, if allowed, to make the occupant of 'St. l'eter's chair the veritable lord and master of the globe.

In earlier and better times, before the arrogance of Rome had quite gained the mastery in England, the crown, supported by Parliament, had exhibited considerable spirit in defending and safe-guarding the nation. Enactments had been erected as bulwarks against papal encroachment. The first of these, the root of the Statute of Provisors (3\% Ed. I.), called the Statute of Carlisle, was passed, 1307, against the extortions of the lapacy. This Act was followed by more stringent P'arliamentary enactments. Provision to benefices by the pope was condemned by two statutes in the reign of

* Latimer's Surmons, P.S., p. 189; B., iv., part iii., 5169, 5970 ; Appendix, 272, etc. Pope Sixtus IV. (died 1454) first, says Roscoe, rpenly sold benefices.- 'Life of Lorenzo de'Medici' (Bohn's edit.), p. 219. Henry VII. of England received money for bishoprics. See Miluan's 'Lat. Christ.,' iv., p. 13, etc. 
Edward III. (2.5 Ed. III., st. 4, and :3s Ed. III., st. 2, e. 1). The former of these was known as the Statute of Provisors. And in 1:39:3 the celebrated l'remunire (a eorruption of premoneri) Statute forbade the purchasing at Rome 'translations, Bulls, or any other instruments which touch the king, ete.,' under terrible penalties. Such as were found guilty were put out of the king's proteetion, and forfeited their all to the crown. Such statutes-a solid basis of just defence-made strong the national front against Rome and her exactions. Nor was their authority suffered to remain in abeyanee when the relations of England to Rome became matter of profound agitation on all sides.

Change, indeed, was near at hand-ehange social and religious: revolutionary ehange was even now at the door. The sound reached the ear amid the discord of feudal eonflict. Gumpowder, a discovery attributed at the time to the enemy of all good, erelong proved a rude and rough, but real, friend to man. The king alone possessed a regular train of artillery; and the baronial fortress, erst impregnable, crumbled into ruins before the eannon's thunderbolts. One of the latest outbreaks of feudal turbulence is depicted in the 'Paston Letters.' Sir John Fastolf, distinguished like Earl Rivers and John Tiptoft, Earl of Woreester, as a lover of books, had bequeathed Caistor Castle to executors, who were directed to eonvert the fortress, with its revenues, into a college. The Duke of Norfolk elaimed to have negotiated a purehase of the eastle. There was no recourse to any means of settling the dispute so paeifie as law. Summoning his retainers, to the number of three thousand, the duke laid siege to the castle, whieh, although strong, being slenderly garrisoned by only thirty defenders, after a gallant resistance, wherein blood was shed, surrendered. The duke eould then retire to his own fortified stronghold, fearless of punishment. A few years and the improvement in artillery had rendered the baronial stronghold untenable, and had thus gone far to depress the power and uproot the tyranny of the noble. The subsidence of a turbulent aristoeracy was a necessary preliminary to the consolidation of the monarehy and the establishment of the royal supremacy. 
To the discovery of gunpowder, the invention of the art of printing suceceded a little later; and in conjunetion with another invention, which, although made long before, was now only brought into general use, that of the method of eonverting rags into paper-linen paper in place of the costlier parchment -aecomplished for the communieation of mind with mind much what has been aceomplished by steam propulsion in our own age, for personal communication and the interchange of merehandise. Gunpowder gradually demolished the ancient system of feudalism; printing gradually destroyed that monopoly of learning which had so long been vested only in the few, and almost exclusively in the elergy. Through a mouldering world of fading privilege, a new and more expansive world was bursting into life.

It is interesting to look back on a distant age, which was the seed-time of our own ideas and institutions. Enlightened by the statutes* and other reeords of the past, we may picture Vanity Fair playing its active rounds in the opening years of the sixteenth eentury in the great valley of English life. Heads are there that might wear erown or eoronet. The blood royal are conspicuous in eloth of gold of purple, or in silk of purple. Purple was the royal colour. 1)ukes wear cloth of gold of tissue; earls, sables or 'black jenett'; barons, silk, broidered with gold or silver; some of the retainers wear their lord's badge, despite the Statute of Liveries. The lord's son is distinguished by doublet of velvet. Merehants with 'forked beard,' like graduates of the universities, are in furedged gowns; doctors of physic are in elose-buttoned doublet and long-gown with hanging sleeves; attorneys in caped gown and round flat eap. The lighter aceessories of soeial recreation are not absent: fantastic morrice-daneers, with pearls in their ears: musicians, with their viols; the poor fool, in his motley; the ape, with his anties. Apart from these stand the spiritual throng-cardinals, in scarlet; bishops, in violet robes; the tonsured boy-bishop; ' unpreaching prelates,' booted and buttoned, or in full eanonieals; easy-going pluralist reetors; the sagacious mitred abbot, ecelesiastical dignity adding a

* Four statutes were passed under Henry VIII. to regulate apparel1 Henry VlII., c. 14 ; 6 Henry, c. 1 ; 7 Henry, c. 6 ; 24 Henry, c. 13. 
tonch of seriousness to land-owning pride; monks of many sorts, some with greyhounds, as though field sports were their real vocation; 'lousy fat-paunched friars,' 'black, white, pied, gray.' The fair sex are represented in exquisite variety: nobly-born dames, in ermine; youthful ladies, with hanging sleeves and high ruff's, their faces painted to the height of the fashion, or masked for dance or revel; veiled nuns, the young and the wrinkled-some that might recall Chaucer's description of the 'prioresse.' Besides these, nor least characteristic of the age, there is the colporteur, with his disguised book-pack; and a knot of heretics, some abjured, a silken figot on their dress-others condemned, an actual fagot on the left shoulder. The whole moving scene has vanished long since, never to be reproduced. In its place a new Tanity Fair, of different shapes and colouring, is now disporting its altered fashions for its short term. Already, at the period referred to, beyond the misty valley, the horizon along the line of the hilltops was red with the refracted rays of rising light. 


\section{TABLE OF MATES.}

15tr. League of Cambray against Venice.

190!. Henry VII. dies, April. Henry VIII. weds Katharine, June.

1513. Battle of Guinegate (Spurs), $16^{\circ}$ August. Victory of Flodden, September.

1514. Lonis XII. weds Mary Tudor, Angust.

1515. Louis XII. dies, 1 January. Francis I. victor at Marignan, 13 September. Wolsey a cardinal.

1516. Ferdinand of Aragon dies, 23 January. Mary born to Henry and Katharine, 16 February.

1517. Charles V. arrives in Spain from Flanders. Luther assails indulgences.

1518. Ximenes deceased. Charles V. enters Valladolid. Wolsey papal legate, 17 May.

1519. Maximilian dies, 12 January. Charles V. elected emperor, 28 June.

1520. The Field of the Cloth of Gold, 7 June.

15.1. Henry's 'Assertion of the Seven sacraments.' Leo $\mathrm{X}$. dies, 2 December.

152.2. Adrian VI. pontifr, January.

1523. Adrian VI. dies, September. Lnther answers Henry VIII. Clement VII. jontiff, November. Bourbon joins Charles $\mathrm{V}$.

1524. Treaty between Charles V. and Henry VIII., 24 May, to invade France. Bourbon invades Provence. Francis I. erosses Mont Cenis and surprises Milan, September.

1525. Despatches of De Prä̈t seized, 11 February, by Wolsey. Francis taken prisoner at Pavia, $2+$ February.

1526. Treaty of Madrid, 14 January. Francis released, 18 Mareh. 'Tyndale's version of the New Testament in London, April.

1527. Sack of Rome, i May. Bourbon slain.

152 . The persecution in London, and at Oxford especially. 
BOOK II.

PREPARATION.

\section{I.-THE CLASSICAL REVIVAL AT OXFORD.}

THE European mind underwent an important quickening in the twelfth and thirteenth centuries. Then the careful study of the Roman jurisprudence and the sharp quibblings of the scholastic theology flourished with increasing vigour, and at the same time-however unlike in character-the lyric lovestrains resounded of the Provençal poets. But to this earlier wave of mental excitement and energy there succeeded the more stirring impulses of the great classical revival. A new and powerful influence was spread throughout Europe-the precursor of deeper and more vital changes, spiritual and intellectual.

English was the last formed of the European languages; and of the principal nations of Europe the English were the last to cast off' the slough of barbarism. When Poggio visited England, in 1420, he remarked upon 'the barbarous and obsolete' nature of the university studies. The Oxford of some years later has the same epithet-'barbarous'-applied to it by Hallam. There were, says Hallam, only three or four scholars in England at that period who had 'any tincture of Greek.' But an absorbing enthusiasm for the study of the nobler and more valuable of the two ancient classical languages seized educated Europe, as it were by storm, shortly after the capture in 145:3 of Constantinople by the Ottoman Turk. In the city of Chrysostom, the language in which he had preached was still spoken; and its capture by the Mussul- 
mans drove a number of learned men from their old haunts, who carried to Florence, Paris and other intellectual centres Greek manuscripts, of which they professed themselves, as they generally proved to be, capable exponents. The advent of the Greek scholar was the dawn of European enlightenment. The Florentine democracy, whose 'restless waves had rocked' the rapidly-matured genius of Italian literature, welcomed Greek culture with intense sympathy. The ardour diffused itself from Florence throughout Italy, and, passing to other lands, brought under its spell, ere many years had elapsed, both Oxford and the sister English university. Some choice spirits crossed not only to Paris, which by its earlier celebrity, and the attractive erudition of its Greek scholar Budé (Budreus), was in advance of the English seats of learning, but travelled to Italy and to Florence itself, there to enjoy to the full the remains of ancient genius amid congenial associates.

The powerful impulse thus given to higher tastes and just ideas was essentially necessary for the true direction of the new era which had recently opened. Modern thought and enterprise, elate with boundless enthusiasm, were in the full flush of their springtide. Copernicus had exploded the Ptolemaic astronomy, and revealed the true system of the universe. Columbus had discovered (1492-93) the West Indies, and enlarged the world by another hemisphere. Portuguese mariners had rounded the Cape of Good Hope (1497), and it was not long ere merchant ships from the shores of Europe anchored in the havens of India. Caxton had been established in the 'Almonry at Westminster'; his advertisements of books printed at his press, which he offered for sale, were attracting princes and nobles. The printing-press was superseding the monastic seriptorium and the oftice of the trade guild. Old-world ways and fancies were waning. The world was in the throes of its new birth.

It was on such a scene, radiant with the many hopes of aspiring youth, that the classic genius of ancient Greece, reawakened as it were from the long trance of the tomb, poured in increasing flood its vivifying and strengthening beams. No doubt the mixture which ensued of paganism with ('hris- 
tianity was grotesque. Classic literature and the inspired Scriptures were treated as parts of one and the same revelation. Orpheus and Moses, l'Jato and Christ, were placed in close association.* The supposed birthday of Plato (November 29) was kept as religiously by the Florentine Academy as the anniversary of the conversion of St. Paul or of the martyrdom of St. Peter. After this Italian fashion we find, even later than a century afterwards, in the poems of our own Milton, the fictions of heathen mythology and Christian fact interworen. But however strange the combination, the general benefit to the cause of human progress from the enthusiastic reception of the revived classical lore was incalculably great.

The poets, philosophers, historians of ancient Greece supplied nobler literary models; and at the same time laid open in various directions novel and interesting fields of speculation, and thus supplied topics, some of profound importance, for reflection and discussion. The intelligence was thus stimulated to give birth to new creations, as well as to copy in a modern tongue the beauty of classical form and expression. Above all, the study of theology derived a new and true starting-point. Scripture was purged from the false conceptions which had been attached to it by divines ignorant of Greek. The New Testament-not only the safe guide to a better world, but educationally of inestimable value for the present life-received a just and more vivid interpretation. Upposition was, of course, immediately aroused. The scholastic party rallied round Latin as the very palladium of orthodoxy. Thomist and Scotist were at one in urging that the pursuit of Greek literature would breed heretics, as Hebrew scholarship would beget. Jews.

One happy result of the classical revival was that the stream of Christian benevolence was thereby made to run at an accelerated pace in the useful channel of building and endowing grammar schools. This was a necessary preliminary to the introduction of a sound reformation of religion. Within the thirty years preceding that welcome revolution, Dr. Kuight states, in his biography of Colet, that there were more grammar * See Robertson's 'Christian Church,' iv., pp. 667-66!. 
schools erected and endowed in England than had been founded in the previous three hundred years.

The honour of being the father of Oxford Greek scholarship belongs to Cornelio Vitelli, who taught (14\$s) voluntarily at Magdalen Hall that most exaet and copious of languages. Vitelli did not remain long at Oxford; but he left behind him disciples who earried on the work of instruetion begun by him with his own disinterested devotion.

Foremost among these was William Grocyn, of Bristol (died 1522), Fellow of New College, who had been a schoolfellow at Winehester of William Warham, Arehbishop of Canterbury, the Oxford ehaneellor. Grocyn travelled to Italy, and sojourned there (1488-91), making Florence his headquarters, beeame intimate with the IJedieean family, and enlarged and deepened his elassieal lore under Chaleondyles and Politian. On his return (1491) he resicled at Exeter College, and there taught Greek. ('roeyn attraeted to ()xford, and bore part in the instruetion of, the celebrated Erasmus, who had acquired the rudiments of Greek in boyhood under Hegius at leventer, in a school of the 'Brethren of the Common Lot,' and in his self-rledication to Greek learning spared neither pains nor money. It was the rule of Erasmus-in full accord with the enthusiasm of the age-to purehase Greek books first and elothes afterwards.

Besides Groeyn, three other Greek scholars are worthy of espeeial notice:

First may be mentioned Thomas Linaere (died 1.5.2), from whose skill and instruction in Greek both More and Erasmus derived profit, and whom the latter praised for his nice and exact judgment, as he praised Groeyn for his extensive knowledge. Linaere was a pupil of Selling, the prior of Christ Chureh Convent, Canterbury. He studied at both the English universities, besides spending two years in Italy. He was a physician as well as a seholar, and not only was the compiler of a Latin (irammar, too eritical for general use, but was also the translator of Galen; was the founder of the college of Plyssicians, and the founder also of three lectureships of medicine - two at Oxford and one at Cambridge. ${ }^{*}$ The trans-

* see 13. iv., part i., 731), 8:8. Vives wrote to Erasmus from London, November 1:3, 1524: 'Linacre is dead (reliquit homines), to the great 
lation of Galen has been recognised as the starting-point of English medical science.

IVilliam Latymer, 'the modest, retiring scholar,' pupil, like Thomas More, of Nicholas Holt, the master of St. Anthony's Hospital School, had studied Greek at Padua with Bishop Tunstal, and was solicited to instruct in Greek Bishop Fisher, of Rochester, but excused himself from the task on the ground of the bishop's very advanced age. Latymer enjoyed the distinction of rendering assistance to Erasmus at Cambridge in preparing the second edition of his Greek Testament.

Wrilliam Lily was born at Odiham, in Hampshire, and entered Magdalen College, Oxford, in 1486, when seventeen or eighteen years old. Grocyn, the divinity reader at Magdalen, was his godfather. After taking his degree, Lily made a pilgrimage to Jerusalem; after which he studied Greek at Rhodes, and subsequently completed his classical attainments in Italy under Sulpicius and Sabinus. At Rome he again met Colet, whom he must have known before at Oxford. He was appointed in 1512 master of St. Paul's School, and, unlike the ordinary schoolmaster of that period, was, says Lupton, 'the prototype of the highly-trained scholar often found in that profession at the present day.' The post he held ten years.

Placed at the head of the advancing school education of the time, Lily added a Latin syntax to the 'Construction of the Eight Parts of Speech,' which Colet, dissatisfied with the grainmar of Stanbridge and Whittington, had himself composed. To his Accidence Colet had added a 'Catechizon,' or rudiments of religious instruction. Colet's Accidence and Lily's Syntax Erasmus revised, making many alterations. The 'Propria quæ Maribus' and 'As in Presenti,' familiar to many bygone generations of schoolboys, were Lily's own work, with such help as was afforded by some existing memorial lines. Afterwards .John Ritwyss, * a Cambridge friend of

grief of all doctors.' Linacre suffered from the stone, like Erasmus. 'I will endeavonr,' wrote Erasmus to Richard Spercheford, - by the help of Linacre's Syntax, to become a good grammarian: do you, from the "Chrysostom" I send you in return, endearour to become a good preacher.'-B. is., part ii., $335 x$.

* Spelt 'Rightwise' in Henry's 'Priry Purse Expences '- 'To Right. wise, schoolmaster of Ponles, 1139 9.'-January, 1531, B. v., 763. 
Erasmus, recommended by him to the post of sur-masterwho afterwards married Lily's daughter, Dionysia, and eventually succeeded his father-in-law in the mastershipgave the book some finishing touches. This old Grammar, which, in shape not much altered, retained its supremacy for upwards of three centuries, must be regarded, like the school whence it emanated, as an English firstfruits of the classical revival; nor is the more modern Primer, which has now superseded it, whatever superiority in other respects it may boast, its equal in adaptation to the mind of boyhood.

In the closing years of the fifteenth century the most prominent figure at Oxford was the excellent John Colet, to whom, notwithstanding Mr. Lupton's admirable biography, a higher place is still due among our national benefactors than has even yet been assigned to him. He is described as ' of a tall and comely personage.' His life was passed in unselfish usefulness and zealous devotedness to the noblest ends.

Colet held various preferments early in his career, such as Dennington and Thurning, before he was promoted (1504) to the deanery of St. l'aul's. He is worthy of ever-grateful memory as the chief of those ecclesiastics on the very edge of the English Reformation who by word and deed paved the way for its success. Of sincere piety and an enthusiastic temper, he became eminent as a preacher, having the boldness to deviate from custom and himself preach in St. Paul's on 'Sundays and other solemn festivals.' His sermon, at the request of his friend, Archbishop Warham, before convocation (February, 1.511-12), on 'Conforming and Reforming,' was an appeal for Church reform in the elearest trumpet tones to the prelates themselves." His sermon a little later before the king, on Cood Friday, 1513, against war, at the breaking out of war with France, was a convincing proof of high moral hardihood. His second sermon at Henry's request, to except a 'just war' from his severe animadversions, greatly pleased the royal ear; so that Henry, disappointing the expectations

* 'In this sermon of Dean Colet to a popish synod there is no manner' of popery, but in the phrase of "doing sacrifice," i.e., saying Mass, and the exeniption of the chergy from the eivil magistrate,' etc. - Knight's 'Colet,' P. 17.). Lupton's 'Colet,'p. 180, etc. Colet's sermon should be compared with Latimer's before the convocation of $1 . ; 3$, . 
of the narrow-minded Fitz-James, Bishop of London, and Colet's many other calumniators, drinking a glass of wine to him, declared: "This shall be my doctor before all other whatsoever.' His bold plainness of speech, in which he was the precursor of Hugh Latirrer, helped to kindle in the breasts of the Londoners, or rather to deepen and inflame, that disgust of the Roman yoke in which they exceeded all their fellowcountrymen.

His life in the deanery, or in his mother 'Dame Christian's' country-house at Stepney-now hard at work in his library with Peter Meghen, 'the famous one-eyed scribe of Brabant;' now spreading his table with hospitable but frugal fare, taking care to have Scripture read to his guests, and following up its lessons by suitable conversation; now succouring the impoverished, or pleading with the king on behalf of some poor persecuted Lollard-seemed a return to the self-forgetfulness and single-mindedness of Apostolical piety.

He was son to Sir Henry Colet, mercer, more than once lord mayor of London, by his wife Christian, a woman of sense, piety, and good birth. She was daughter to Sir John Knevet, of Ashwellthorpe, Norfolk, and lived to extreme old age, and survived all her children. Of these, as many as twenty-two in number-eleven sons and a like number of daughters-John was the eldest and the only one spared to his parents - ' an abundant consolation,' observes Knight, 'for the untimely loss of the rest.' Through such sad domestic bereavements did John Colet, putting a severe restraint on his natural propensity to 'love, luxury, sleep and jocoseness,' have his early religious convictions strengthened and matured as he grew to riper years.

The most brilliant ornament of Oxford at this epoch was Thomas More, of Canterbury Hall, or, according to Wood, of St. Mary Hall, with whom Colet became acquainted (1492-93), having been educated at the same school-' the best of the time,' says Knight, 'at Stepney.' Of More Colet was wont to speak as the one sole genius (unicum ingenium) of England. It was the custom of that age for girls of good birth to be brought up in the family of some lady of consequence, their friends paying for their board, and for youths of promise to 
be trained in the houschold of some great man, waiting on their patron and upon his guests at table. Thus More waited at the table of Cardinal Morton, who had been a prineipal instrument in the revolution which placed Henry VII. on the throne, and was himself nourished mentally by the conversation which he heard. 'That lad,' Morton would prediet, 'now waiting upon us, whoever may live to see it, will one day turn out a marvellous rare man.' From early manhood More took as his model Pico della Mirandola, Savonarola's disciple, of whom it is recorded that he was aceustomed to lament the many years he had spent in poring over the Schoolmen as a 'laborious idleness.'

The countenance of More was irregular in features, keen in expression; nose pointed from under arehed brows; restless gray eyes; thin eanstic lips. His hair, of a reddish.black colour, was commonly disordered; his gait and garb negleeted; his right shoulder seemed to be higher than his left-a disfigurement caused by much 'leaning on his breast in writing.'* He united the learning and thought of the recluse to the knowledge of human nature and quick perception of the man of the world. At the same time lawyer, diplomatist, statesman, scholar, poet, historian, religious controversialist, his character was as varied as his mental endowments. He seemed a eompound of opposites. One hour his compassion would be deeply touched, and he would be bathed in tears; the next he would overflow with wit and merriment-never merrier, however, than when, by resisting temptation, he had, in his own words, 'given the devil a foul fall and won the day.' In early life he strenuously advocated religious toleration, plearling that it is not in a man's power to 'believe what he list.' later on few persecutors displayed more unrelenting acerbity. Two eontradictory natures had met in him, and seemed to struggle for the mastery. A friend to the new learning, giving eurrency by his pen to its liberal speeulations, and yet exceeding these in his own original suggestions; a jester at inonks, drinking in with relish the gibes and seofts of

* Singer's Roper's 'More', p. 49. Harpsfield states: "Sir T. More's skin was somewhat white.. . saving that some little thin red sparkles everywhere appeared." 
Erasmus, pedantic as these sometimes were, he all the while wore next his skin a hair shirt, and looked forward as his day-dream to ending his days in entire sanctity in a Carthusian cell. Grocyn admired the rare promise of a capacity large and diversified. But More was early removed from his Greek studies by an exacting father, who feared that the philosophy of Plato and Aristotle would be incompatible with needful attention to the legal pursuits in which he delighted to anticipate the splendid success of his gifted and only son.

It was after he had gained More's friendship that Colet in 1493 - 'like a merchant man,' says Erasmus, 'seeking goodly wares'-visited France and Italy. He was long at Orleans, a distinguished school for the study both of the civil and canon law. Italy and Florence could boast still greater attractions. The period of Colet's visit was auspicious, but it is not recorded that he held communication with Savonarola, the reforming Dominican-whose pulpit declamations Michelangelo loved to listen to-who was then nearing the bounds of his earthly career; or that he conversed with Marsilio Ficino, who had been educated under the auspices of Cosmo de' Medici in the mysteries of Plato, and, by the direction of the magnificent Lorenzo, had recently translated that philosopher's writings into correct Latin. Yet, although the record be wanting that he heard the great Dominican preach, whom he himself as a preacher took in some measure for his model, and that the enthusiastic Platonist, from whom his curiosity had much to learn, did not remain unknown to him, are points beyond serious doubt. Florence had been, and was, the cradle and home of mighty intellects-such as Brunelleschi, who fifty years before had crowned its cathedral with the famous dome which towers above St. Peter's; of Leonardo da Vinci and Nichelangelo; more remotely, of Cimabue and Giotto, of Dante and Boccaccio. Politian was just dead, most prematurely; Pico della Mirandola was also gone. But at this time Machiavelli was often seen in its streets, not as yet, as afterwards, notorious. Amerigo Tespucci was then absent on one of his voyages. At that very time, however, the pencil of Fra Bartolommeo was adorning the walls of San 
Mareo. The Platonic Academy, presided over by Ficino, was flourishing in youthful vigour.*

Neo-Platonism, over which, in its pristine development at Alexandria, ('hristianity had triumphed, as more than realizing its deepest instincts, was exerting in its modern reproduction a spirit hostile to the debased Christianity of Rome. The Greek grammarians had taken with them into Italy the writings of Plotinus, Iamblichus and Proclus. The mystic writings attributed to Dionysilis the Areopagite-' the highest of all the Platonists,' according to Ficino-were also held in great esteem. "With these last Colet was captivated. 'Dionysius,' he observed, "left written down by his productive pen what he retained in memory of the institutions of the Apostles in arranging and regulating the Church.' The opposition here to existing papal ceremonial was clear and decided. And although the writings ascribed to Dionysius were found to be spurious-a discovery which Grocyn made, as Erasmus recounts, when he was lecturing on the 'Celestial Hicrarchy' $\dagger$ in St. Paul's, and honestly confessed in his next lecture-yet they presented a picture of ecclesiastical usages more ancient than those then prevalent, as well as less irrational.

Colet returned from Italy in 1496, not a mere humanist or Platonist, such as Grocyn or Linacre, who-with the devotion of Ficino, would have kept 'one lamp burning before Plato's image and another before the Virgin's'-but an earnest practical Christian. In Michaelmas term, 1496, he announced that he would deliver a course of lectures gratuitously on St. Paul's Epistles. He took the First Epistle to the Corinthians as his first subject. In his lecture, discarding the established scholastical method of interpretation, he introduced the historical-a sensible and noteworthy improvement. His whole soul burst forth in these lectures. He seemed to his hearers 'like one inspired, raised in voice, eye, his whole countenance and mien, out of himself.'

It was in 1598-99 that Colet made the acquaintance, at

* Lupton's 'Colet,' pp. 50, etc.; Green's 'History of the English People,' ii., pp. Ts, etc.

$\dagger$ The Paris edition of IDionysius' 'Celestial Hierarchy' was published 149\%. Grocyn's lectures were delivered soon afterwards - Seebohm's 'Oxford lieformers, second erlition, pp. (11-9?3. 
Oxford, of Erasmus, then just arrived in the retinue of Lord Montjoy, his pupil, from Paris. The accomplished scholar was hospitably entertained by Richard Charnock, l'rior of St. Mary's College of Augustinian Canons, situate near the present New Inn Hall. That Erasmus should here take up his abode was natural, from his early connection with the Order.

Colet's newly-acquired friend had no equal in his own peculiar province. He knew no English, no modern language except his native Dutch, nor did he care to learn any. It was the universal medieval tongue-Latin-which was peculiarly his own. In this be thought-this lie wrote, spoke and loved next after the Greek; although with the latter language he never became equally familiar. To this obsercant citizen of the world, unmatched in his use of the contemporary world's tongue, belonged the task, negative, but necessary, of removing obstacles in the way of religious reform by loosening the hold of error and superstition, and thus straightening and preparing the road wherein men more heroic, of deeper faith and firmer purpose, might advance, proclaiming forgotten truths, and recalling the Church to her primitive simplicity. The Greek Testament of Erasmus, with its clear Latin version, was a more positive service to religious enlightenment. Erasmus and Colet, at the date of their first meeting, were in the prime of life, having both just passed their thirtieth birthday, Erasmus being a little the senior. More was ten years younger.

At a distance of more than three centuries and a half, the intelligent, sickly face of the scholar of Rotterdam, with its parchment skin, is still familiar to us. By no means proud of his native country, which he contemptuously styled 'beer and butter land,' he belonged to the whole civilized globewandered from shore to shore, from university to university, and library to library, knight errant, as it were, in the cause of reviving literature and what he regarded as rational piety. Very complicated and elaborate were the ceremonies and ritual of Rome. Its long service, in Tyndale's words, 'was wondrous intricate, so that in a dozen years thou couldst scarce learn to turn aright unto it." Erasmus taught with the shrewdness of * Tyndale's Works, P.S., ii., p. 2!\%. 
common-sense that the Christianity of the Divine Master Himself is perfeetly simple. The illiterate, he maintained, were just as capable of understanding it as the learned. From amidst an oppressive aceumulation of perplexing subtleties he looked back with regret on the less sophisticated age, when the Church had a single ereed, 'the shortest' as well as 'the most ancient.' Here Colet and the scholar were quite agreed. About the rest, the dogmas in excess of the Apostles' Creed, Colet would remark impatiently, 'Let divines dispute as they will.'

The aequaintance, begun by an interchange of complimentary epistles, soon ripened at the table, and under the influence of their joint friend, the Prior of St. Mary's, into close friendship. Vet the friends were widely diverse. Colet was austere, and even ascetic. A stern disciplinarian, especially as regards the training of youth-much too stern in the judgment of Erasmus, who had himself been a victim to over-severity in his boyhood-Colet met evil with rehement denunciation, not with the Duteh scholar's light weapon of ridicule. When they stood together (151t) before the gorgeous shrine of Thomas Becket at Canterbury, and were shown the saint's relics, and the prior presented to Colet, as a distinguished visitor, a piece of the cloth wherewith the martyr had been wont to wipe his face and neck, as a very preeious gift, the dean could not forbear signifying his disgust by expressive gesture.t When they were leaving the sacred preeinets, and an old mendicant from the hospital held out the tip of the martyr's shoe, patched with glass, to be kissed, Colet was again fired with indignation. Erasmus solaced the old friar with a small coin. A powerful lecturer and preacher, discarding in his sermons the trammel of notes, Colet was nevertheless unable to express himself in writing with any very near aplroach to his friend's easy gracefulness. 'Of such a man,' said Erasmus, 'let us have the thoughts, however they may be expressed.' 'In heretical pravity ('olet outstrips me,'-so joked Erasmus; but joking uttered truth. Colet guided the scholar to set little store by Scotus, Aquinas, and the schoolmen. But in fact Scholasticism - that

* Preface to Erasmus' 'Jerome.'

$\dagger$ "Gratianus Pullus (Colct) contemtim reposuit, porrectis labris, veluti poppysmum imitans." I'eregrimatio Religionis ergo, Eiresmi Colloquia. 
is, the treatment of Augustine's doctrines on the principles of Aristotle, the brand of medieval theology--was fast losing ground. By its daring speculations, on points, however, for the most part, of small practical moment, and its subtle quibbling distinctions it had given exercise and added strength to the acutest intellects for four centuries, from Anselm to Gabriel Biel. But its day was now terminating.

Full of interest were the theological discussions between Colet and Erasmus, whether at the Prior's table or elsewhere. In one of his letters to his friend Erasmus remarks: "The other questions which you proposed from St. Paul's Epistles it will be better, for safety-sake, to dispute by word of mouth in our afternoon perambulations.' Picture Colet and Erasmus absorbed in theological controversy as they take their evening stroll on the banks of the Isis, while a knot of the numerous students, who were then congregated at Oxford at the colleges, hostels, and religious houses, follow their footsteps with curious gaze! The walks of Colet and Erasmus in the University outskirts may compare, for interest, with the celebrated row of Grocyn and Erasmus up the Thames to Lambeth, on the latter's seeond visit to England, in order to present the Latin version of the 'Hecuba of Euripides,' done by the scholar of Rotterdam, to the learned and genial Warham. The two scholars, however, rowed back, joking and laughing together that the honorarium expected had not been forthcoming.

Colet, who was termed by Erasmus his 'preceptor,' and who stood to More in the confidential relationship of 'father confessor,' was a welcome link between his two dearly loved friends. And thus was knit together that able Oxford triumvirate, potent for good by the inter-communion of vigorous minds in search of truth, and by the furtherance of wholesome Christian learning and sound literature, at a momentous epoch in our national growth.

Colet's piety made Christ Himself the centre and essence of Christianity, the divine life, character, and teaching. Devoted to the noblest aims, he did not seek money; but money was poured into his lap as by some invisible hand. His wealth he spent for the highest ends. His chief memorial is St. Paul's school, which he founded in 1509-10-a free school for one 
hundred, fifty and three sons of poor parents-a sehool which was quite distinet from the Cathedral School. The schoolhouse was ereeted by him in the eastern part of St. Paul's ehurehyard. Colet, without being much of a Greek seholar himself, was especially desirous that his seholars should become profieient in that language; so that Thomas More likened them to the Greeks hidden in olden time within the walls of Troy in the wooden horse, who thenee issued and took 'the barbarous eity' by surprise.* The sehool was dedieated to the Child Jesus. The image of Jesus in the gesture of teaching, stood over the Naster's ehair with the command of God the Father-Heur Him, graven as a motto. The munifieent Founder asked his scholars' prayers: 'Lift up your little white hands, and pray for him who prayeth for you.'

The leaders of the new learning, of whom Colet was the chief, were able and useful pioneers of the English Reformation. I) Iscarding the theory of verbal inspiration, they built up their religious system upon the faets of Christianity; they dwelt upon the prevailing tenor of Scripture rather than isolated texts, paying supreme regard to the utteranees of the Master Himself. But their principles, however acceptable to some thoughtful minds, were not ealculated to make much impression on the average bulk of characters. They were thus only the pioneers of a more influential movement which soon followed. Not one of the three-Colet, Erasmus, More - so much as dreamed of departing from his position as a faithful son of the Chureh of Rome, under the Pontiff's supremaey. And, in faet, St. Paul's Sehool itself, the light of More's example in death and life, and the Greek Testament of Erasmus, are now almost the only memorials that remain to us of the Broal Churehmen of the sixteenth century.

At the same time Thomas Wolsey was headmaster of Magdalen College Grammar School. Born at Ipswich, the son of liobert Wolsey, or ' Wuley,' who eombined the trade of a butcher with the business of a well-to-do grazier, the future statesman was supported at Oxford by beneficent patrons, and

* It is noteworthy that Colet was suspicious of the moral influence of the classical writings upon his scholar's. He would have them learn Ciceronian prose from Lactantius rather than Cicero; Virgilian verse from Baptista Mantuanus rather than Virgil.-Lupton's 'Colet,' p. 77. See School Statutes, in Appendix, p. 279. 
evinced singular mental preeocity, graduating so early as to be known as the 'boy bachelor.' Magdalen 'Tower, completed 1498 , when he was bursar, has been often quoted as a memorial of the great Cardinal's early architectural taste. Wolsey, like Warham and the other more distinguished prelates of the time, favoured the classieal revival; but for his own course in life he clearly discerned the Chureh to be the ladder up which he must climb from insignificance to greatness. Like Colet, when he rose to wealth and power he fostered education, and endowed Cardinal College at Oxford, supplementing it with another Cardinal College in his native town. In planning the latter he eopied largely from St. Paul's School, even reprinting (1528) Colet's 'Rudiments.' His Ipswich College he intended as a nursery to his magnificent Oxford foundation, as Winchester School was to New College.

Thus at the same epoch there were collected at the Alma Iater on the Isis thinkers and actors, apostles of the 'new learning,' destined to play foremost parts in their country's history, but concentrated for a time like waters in a brimful well-head, which shortly part, dispersing miles and leagues asunder their fertilizing streams.

There had been a long-running feud between the secular clergy and the mendicants, and also between wrangling philosophical schools, such as the Nominalists and the Realists. And now, by the introduction of Greek eulture, a new apple of discord was flung among the eager ranks of University disputants. A party, nicknamed Trojans, decried the study of Greek. To the elimax of this narrow-minded intolerance Hallam assigns the date of 1519 ; but before that time the jealousies of the scholastie logicians against the humanists had been aroused, and had been growing in force and virulence. The votaries of the school theology, however factious in their bitter disputes against one another, were agreed in the intensity of their common hatred to Greek. More suggested in his 'Utopia' that the 'noisy Scotists,' the 'obstinate Occamists,' the 'invincible Albertists' should turn their energies into an instrument for the public gain by directing their fury against the Turks and the Saracens. But they hiad now found a common object of antipathy at home in the recently much-patronised Greek. 
At Cambridge the hostility to Greek was less acrimonious. Here the leading character was the steadfast John Fisher, who had been eonsecrated Bishop of Rochester 1504-when Fitz-James was translated to London from that see-and the same year had been appointed Chancellor of the University. In 1.514 , so much was he valued and revered, that he was appointed Chancellor of the University for life. Fisher had been born in 14.59 in the north of England-as his very broad accent in speech testified-at Beverley, the son of a merchant of that town. It is a lasting honour to his memory that he was the founder of St. John's College, Cambridge, having obtained from the Pontiff a Bull for the dissolution of certain nunneries. Although a most determined Papist, Fisher yet favoured the 'new learning,' not only by precept, but by example. He was not ashamed that his 'gray hairs should, as it were, go to school again,' but braced his energies to master Greek, like Cato of old, at a time when his age itself might have been judged an apology for exemption from hard study. Fisher was among the admirers and liberal patrons of Erasmus, who expostulated with him on spending so many hours in his library-his 'paradise'-' surrounded with glass windows,' the sea near him, and 'a muddy shore,' in an age when there was a lamentable penury of worthy ecclesiasties.* The good bishop was forward with other leading dignitaries in inviting the renowned seholar to Cambridge. Extreme was their joy when Erasmus was appointed Lady Margaret Professor of livinity. This professorship had been founded by the Countess of Richmond, the mother of Henry VII., at the instigation of Fisher himself, her confessor and almoner.

The most accomplished scholar of his time was thus enabled to apply to educational advantage at Cambridge the skill in Greek which he had achiered at Oxford and Paris. At first be lectured under difficulties and diseouragements; but in 1.51:3 he was able to declare with thankfulness that Cambridge might ' compete with the best universities of the age.'

When at Oxford the light, which had before irradiated its colleges and halls, gave signs of waning, it was already shining at the sister university with prophetie brightness.

* B. ir., part i., 623 . 


\section{II.-CAMBRIDGE GOSPELLERS.}

WITH the Cambridge Gospellers, of whom it is necessary next to speak, lay the real centre and heart of the movement-at least so far as it was a spiritual movement. To many of the favourers of the New Learning, just as to Ficino and his Academy, Plato had supplied a bridge, over which they had crossed from the Pagan to the Christian shore. The poetphilosopher, who denounced poets, reigned at Florence in the Academy, and among a yet more limited section at Oxford; but his influence was very small at Cambridge. The Cambridge Gospellers sat immediately at the feet of the IIaster himself. Here was the secret of their power, their success, and its permanence. Tyndale, who was soon to be the leader of the Reforming party, was thoroughly at one with them.

A brief sketch of the religious condition of Cambridge at a period a little later than the proceedings at Oxford just referred to, will serve to introduce characters who played a conspicuous part in our early Reformation, and to exemplify their earnest efforts to promote amendment of faith and life.

Foremost among the Cambridge Gospellers must be placed Thomas Bilney, Fellow of Trinity Hall. Short of stature, eminently abstemious in his habits, ' little Bilney,' was remarkable for the austerity of his zealous piety. He was constant at the confessional. Fasts and vigils wore down his strength ; pardons and masses drained his purse. Yet he had no peace of conscience. Erasmus had now left Cambridge, and in 1.516 published at Basle his Greek Testament, with its new and clear Latin version; a bold innovation, for the monks held every syllable of the Vulgate to be inspired. Bilney purchased a copy, not so much because it was Christ's Gospel, as because the charm of the Latinity attracted him. But he soon passed 
from the word of man to the Word of God. Turning over the leaves, he paused on the text: 'This is a faithful saying, and worthy of all aeceptation, that ('hrist Jesus came into the world to save sinners, of whom I am ehief.' 'Oh most sweet and comfortable sentence!' he exelaimed. He closed the book, but only to open it again and again at the same place. 'His bruised bones leaped for joy.' A ray of heavenly light had pierced his soul, and guided him to the grand discovery. Henceforth he har done with the mistaken fancy that prayers, or alms, or self-maceration, or priestly absolution, ean blot out guilt. The 'sharp stings and bitings of his sins' he eased theneeforward by washing by repentance and faith in the blood of the Lamb of God.*

Bilney at once beeame a bearer to others of the glad tidings which had filled his own heart with peace. He prayed God that 'the wicked might be converted unto Him by me,' he writes, 'who sometime was wieked.' One of his first eonverts was Thomas Arthur, Fellow of St. John's. Another convert was George Stafford, Fellow of Pembroke Hall, Leeturer in Theology. It was soon evident that the whole eurrent of Stafford's religious ideas was elnanged. Laying aside the Sentences, he took the Holy Scriptures as the text-book for his leetures. Becon deseribes Stafford as 'a man of a very perfect life, and, if I may so speak, of an angelie conversation; approvedly learned in the Hebrew, Greek and Latin tongues; and such an one who had through his painful labours obtained singular knowledge in the mysteries of God's most blessed Word.'† His lucid expositions made St. Paul ' of a read man alive again.' But his eareer proved as short as it was bright. $A$ few years later Cambridge suffered (1530) from a visitation of the plague. A priest, skilled in witeheraft, lay upon his bed smitten down with the pestilence, and at the point of death. Stafford entered the siek priest's chamber, anxious for the safety of his soul. Nor did his endeavours scem to be in vain; for the eonjuring books were burned, and the priest deelared that he relied for forgiveness only upon the merits of

* He himself narrates his conversion in a letter to Tunstal, B. v., p. 373.

$\dagger$ Becon's Works, P.S., p. 4.5. Latimer relates that Stafford, in one of his expositions, bronght in an 'ensample of a great rich merchant in London (Iumphrey Monmonth).'- 'Sermons,' P.S., p. 4t1. 
Christ. With face beaming with joy Stafford returned home, but, in his turn, to sicken and die.

In the Cambridge of the early part of the sixteenth century, the quaint old Saxon tower of St. Benet's Church looked rlown on the western precincts of the venerable pile of the Augustine Priory,* founded as early as the close of the thirteenth century. The prior at the present time was Robert Barnes, who had studied at Louvain, and, on returning to Cambridge, had applied himself in earnest to the task of restoring a taste for classical literature. In 1523 he was made Prior. Under his encouragement Terence, Plautus and Cicero were now read in the Augustine cloisters; and many were attracted thither by a love of letters, among whom Foxe names Coverdale. The classics, as was usual at this period, opened the way for a purer theology. Duns Scotus and Dorbell were flung aside, and in their stead the Scriptures became the favourite text-book. Barnes next resolved to dispute from the Scriptures in the schools, and the disputation in which Stafford answered to Barnes 'for his form to be Bachelor of Divinity' is reeorded as the first in which the matter of discussion and the arguments were alike drawn from the inspired writings. Yet, all the while, of true heart-felt piety Barnes knew little; his 'inward and outward idolatry' remained. But Bilney's eye had long been upon him. Bilney prayed for him in secret, he imparted to him the lessons which he had himself been taught, and ere long he blessed God for another soul given to Christ.

Bilney had soon to thank God for a still more eminent convert. Hugh Latimer, of Clare Hall, the University Crosskeeper, was notorious for his bigotry - 'as obstinate a papist as any was in England.' He was a formidable disputant on the side of Roman prejudiee, from his ready eloquence and homely, raey humour. In his oration for the degree of Bachelor of Divinity the shafts of Latimer's ridicule were directed against

* Its site was in or very near the Peas-market; its limits may be described in modern terms as Slaughter-house Lane, near ('hrist's College, on the east, Downing Street on the south, and Free School Lane on the west. -Dugdale's 'Monasticon' ; and Cooper's 'Annals of Cambridge.' In the 'Atlas Colestis, seu Harmonia Macrosmica,' Amsterdam, liti i, there is a plan of Old Cambridge. 
Melanethon. When Stafford lectured, Latimer was wont to admonish the students to move away from the contaminating presence of the vile heretie. Yet there was, notwithstanding, in Latimer's charaeter a straightforward honesty which inspired Bilney with the hope that the infatuated Cross-keeper might yet be won from seholastieism and ceremonialism to the pure Gospel of Christ. According to his eustom, he sought guidance from above, and in dependenee on God chose a mode of approach which seemed to yield the fairest promise of an unbiased hearing.

It was the spring of 1524 . Latimer had just returned from his rehement declamation against Melancthon. A gentle knoek at his door elaims his attention, and he bids the visitor enter. He proves to be Bilney, who humbly implores the Cross-keeper for God's sake to listen to his confession. A smile of satisfaetion lights up Latimer's faee. Neekly does Bilney kneel before him and reeount his own past history: his anguish of heart under deep conviction of sinfulness, his long and fruitless strivings to gain peace of eonseienee; how, in his perplexity, he purehased the Greek Testament of Erasmus, and in turning orer its pages had been riveted to a text which communicated peace to him, and had ever since remained indelibly fixed in his memory. Observing that Latimer listens with real interest, Bilney, from quoting one text, goes on to adduce parallel texts, all promising pardon, simply by faith in the efficaey of Christ's atonement. The eonfession over, the confessor is plunged in profound mertitation. As soon as he ean, he searches the New Testament for himself. He continues the search day after day, and ere many weeks have elapsed he has unhesitatingly adopted Bilney's faith as his own. Some years later Latimer related the story from the pulpit to attentive listeners: "Master Bilney, or" rather St. Bilney, that suffered death for God's Word's sakethe same Bilney was the instrument whereby God ealled me to knowledge; for I may thank him next to God for that knowledge that I have in the Word of God. . . . By his confession I learnt more than before in many years; so that from that time forward I began to smell the II ord of God, and forsook the school doetors and such fooleries.'*

$$
\text { * 'Sermons,' P.S., pp. 334-5. }
$$


Latimer's earnest nature now impelled him to preach the doctrine of the Scriptures-a book, long veiled, at last revealed to him-with all that force of language, amplitude of illustration, and keenness of wit wherewith God had endowed him. His preaching grew more than ever attractive, and his influence increased day by day. For he was not merely a preacher; he "watered," says Becon, "with good deeds whatsoever he had before sown with good words." With Stafford he formed a cordial friendship, and would take his station, in hearty support of his teaching by his side, when he delivered his lectures. The judgment of the time is yet preserved in the saying: "When Master Stafford read, and Master Latimer preached, then was Cambridge blessed.'

Thus a powerful phalanx of men, enlightened, zealous, able, was arrayed at Cambridge on the side of the Gospel as taught in the Scriptures. 'The godly learned in Christ,' writes Foxe, 'both of Pembroke Hall, St. John's, Peter House, Queen's College, the King's College, Gunwell Hall (Gonville), and Benet College (Corpus Christi), showed themselves, and flocked together in open sight, both in the schools and in open sermons at St. Mary's and at the Augustines', and at other disputations; and there they conferred continually together.'

The visitor to Cambridge some twenty years ago might have observed a grocer's shop (under the name of Cony) between what is now the Bull Hotel and the scholars' buildings of King's College; and, passing through, would have entered a curious antiquated apartment, formerly lighted by an oriel window, looking into what, in the beginning of the sixteenth century, was the court of the White Horse. One mullion of the oriel window was at that time still in existence; other traces had been destroyed. There was still an old oakpanelling round the greater part of the room. The oak seats that once stood in this panelling are preserved in the Fitzwilliam Museum, but stowed away underground. A passage had been taken out of the apartment, which contracted its size; and the ceiling was low. Where the panelling had been removed from the wall a fresco of King's College was discovered. The late Professor Blunt was wont to urge the attendants on his lectures to go and see for themselves this 
interesting relic of the Reformation period; on which, however, as on so many historic memorials which should have been religiously preserved, the hand of demolition fell ruthlessly.*

Here it was, in the 'White Horse' or Germany, as it was nicknamed, that the Gospellers of Cambridge were accustomed to hold their meetings. The situation was favourable, inasmuch as 'those of St. John's, the King's, and the Queen's ('olleges' could enter nnobserved from the back by King's Lane, which then ran close by the side of the 'White Horse.' There are those to whom it used to be a sacred pleasure some years ago to stand on the worn floor of this neglected apartment, and, by an easy effort of the imagination, people it again with the thoughtful faces of the students who, on the eve of the Reformation, were wont to gather there for prayer and discussion. Here, no doubt, assembled Bilney and Barnes, Stafford and Latimer, and other congenial spirits-possibly, amongst others, Cranmer-at one time their hands raised in intercession and supplication, then their features and gestures growing more animated as they reported the success of personal Christian endeavour, or debated the progress of their common cause.

The ministrations of those who held their meetings in the 'White Horse' were carried into the most destitute and demoralized parts of the town. Bilney visited the 'lazar cots,' wrapped the lepers in sheets, and 'helped them of that they wanted, if they would convert to Christ.' Bilney and Latimer together visited the prisoners in the Tower, read the Scriptures to them, and entered with interest into their individual histories. At a later period Latimer related from the pulpit how he knelt down before the King on one occasion, and obtained the pardon of a poor woman condemned for murder, whom he harl become acquainted with when she was in prison, and of whose innocence he had reason to be thoroughly convinced.

Nor were the evangelizing efforts of these home-missionaries

* Here, too, according to tradition, the Cambridge Revisers (1601-11) held their sittings. The demolition was in order to the erection of the new part of King's College. I am indebted for my information to the Rev. J. C. l'inney, of Gonville and Caius College, Vicar of Coleshill, Wat wickshire, and Cambridge friends. 
restricted to Cambridge. The east of England was traversed by them. At Bury St. Edmunds Richard Bayfield, a monk, was brought over to the simplicity of Christian truth by the teaching of Barnes, and beeame in due scason a colporteur of God's Word, and finally a martyr.* Thus, too, John Lambert, subsequently the intrepid martyr for the spiritual presence in the sacrament, was converted by the instrumentality of Bilney and Arthur.

'Bilney,' says Foxe, 'was a great doer in Cambridge,' and also a great preacher at Ipswich, Norwich and almost all the East Anglian towns; in churches, by erosses, in fields, wherever he could obtain an attentive throng of listeners. At Cambridge it would appear that he counted Cranmer among his intimate friends; at least, after his martyrdom a letter of the Spanish Ambassador to the Emperor deseribed him as ' a companion and sworn brother' of the Archbishop. $\dagger$ His habitual self-sacrifice-his devoted labours for the salvation of others-invested him with much popular respeet and reverence. He rarely slept more than four hours in the night, and commonly took but one meal a day, and that often in some prison or wherever for the time his zeal might have called him to teach and witness for Christ. 'Little Bilney' may deserve a title, scarcely due to any other-at least since Fursey - of the Apostle of East Anglia.

$$
\text { * Burnt November, 1531. † †. vii., } 171 .
$$




\section{III.--THOMAS WOLSEY.}

To Colet and to Bilney must be added the great contemporary English eardinal and statesman, as powerfully contributing to prepare the success of the Anglican Reformation. Thomas Tolsey would have abhorred an ecelesiastical reformation on the basis of Scripture; yet was he, however unintentionally and unwittingly, made use of by an over-ruling Providence to further the very cause which he abhorred. Espceially he was the instrument whereby the Cambridge Gospellers proved the means of a spiritual harvest to the sister university.

Than Wolscy no more extraordinary character stands out conspicuously in the annals of England. Bacon writes that 'Lewis XI., Ferdinando and Henry may be esteemed for the tres magi of kings of those ages.' In the years immediately following there were not only three great sovereigns, but also three great cardinals, who, by foree of character and administrative capacity, reached a commanding pitch of authority and power in their several countries. Of these $\mathrm{W}_{\text {olsey was the }}$ last. Without the popular sympathies of George d'Amboise (1460-1510)-without the high moral rectitude of Ximenes $(1436-1517)^{*}$ - so far, at least, was Wolsey more remarkable

* Jimenes, or Ximenes, de Cisueros, when forty-four years old, suddenly entered the Franeiscan Monastery of San Juan de los Reges (14 changing his baptismal name (Gonzales) to Francisco. Reeommended ly Cardinal Mendoza to be Confessor to Queen Isabella, he was made Arch. bishop of 'Toledo (14!5), against his will, by Pajal command. He was Cartinal 1507. He sililed for Africa, 1501; and himself defrayed all the costs of the war against the Moors. On Ferdinand's death, by his will, he beeame Riegrent for Charles V. He died 8 November, 1517, when 81 years of age, his deeease being hastened by the ingratitude of Charles. His outward jomp veiled the thorough ascetic. He founded the University of Aleala de Henares at his own sole cost. At Aleala (in Latin, Complutum ) was printed the 'Complutensian Polyglot,' at his own expense of half a million dneats. This was not published until 15:2, although finished before.-Alvaro Gomez de Castro's 'De rebus gestis Franeisei Ximenii, folio, 1659 , Aleala. 
than either, that he raised his country by his statesmanship and skilful diplomacy - at a period when English diplomacy was a laughing-stock to the rest of Europe-from being a second-rate power to take rank with France and Spain, and raised himself from the obscure meanness of his birth to a position which has never been equalled by any other English subject.

Tyndale compares Thomas Wolsey, or Wolf-see, as he prefers to call him, according to the custom of his party - with whom a bishop was a 'bite-sheep;' Cardinal Pool (Pole), 'Carnal-Fool;' prelates, 'pil-pates,' etc.-to Thomas Becket,* whose life, he says, was 'like Thomas Cardinal's, but not like Christ; neither is 'Thomas Cardinal's life anything save a counterfeiting of St. Thomas of Canterbury.' The two celebrated English ecclesiastics, however, under the force of different circumstances, so far from presenting a resemblance, present rather a striking contrast to one another, at least in act and outward conduct. Wolsey was characterised by the utmost submission and devotedness to his sovereign; Becket by devotedness to his Church against his sovereign, even at the cost of his life.

Wolsey found his first patron in the Marquis of Dorset. During a Christmas vacation, which he spent at Dorset's country seat, he charmed his patron by his agreeable conversation and elegant manners. He was promoted by Dorset (October, 1500) to the Rectory of Limmington (Somerset), and thus quitted Oxford for a parochial sphere. His life on his first benefice was not free from gross scandal, and on one occasion the Rector of Limmington was put in the stocks by Sir Amyas Paulet for being concerned in a drunken frolic, an affront which Wolsey in his height of power neither forgot nor forgave. He found his next patron (1501) in J)ean, Archbishop of Canterbury, who appointed him one of his chaplains. After the primate's decease he became chaplain (150:3) and coadjutor to Sir John Nanfan, deputy lieutenant of Calais, and resided in France a considerable time. He used this opportunity to

* 'This wily wolf, and raging sea, and shipwreck of all England.''Practice of Prelates,' P.S., ii., p. 307.

Or wolf, or both ; for he is equal ravenous

As he is subtle.'-Shakspere, Henry I'III. 
aequire a competent knowledge of the French language. Nanfan, on retiring from public life, recommended him (1506 or 1507 ) to Henry VII. Appointed a royal chaplain, he obtained the great aim of his ambition, and set 'one foot in the court.' Here his remarkable abilities pointed him out to Richard Fox, Bishop of Winchester, as a tool well adapted to second his schemes and thwart his rival, the Earl of surrey. Entrusted by Henry VII., in the autumn of 1508, on the recommendation of Fox, with a delicate embassy to Mechlin, in reference to his proposed marriage, now that he was a widower, with Margaret, Maximilian's only daughter, his singular promptitude gained him the thanks of his sovereign and the applause of the whole court.

Before Henry VII. died (April, 1509), Wolsey had already used to the full the opportunities placed within his reach, and had won the favour of the youthful Prince Henry. 'He was a man of lust and courage and bodily strength, to do and to suffer great things, and to endure in all manner of voluptuousness,' says 'Tyndale, 'as eloquent as subtle.' His influence over the young prince, now raised to the throne, an athlete in body and mind, soon became paramount. "Was no man so obsequious and serviceable, and in all games and sports the first and next at hand, and as a captain to courage other, and a gay finder-out of new pastimes.' 'A lesson on the art of government would be inculeated,' remarks Lord Campbell, 'over a game at mimero, and after a roystering party at night a disputation would be held in the morning on a question out of 'Thomas Aquinas.'

Promotion now followed promotion so rapidly that Erasmus, in dedicating a book to the aspiring English ecelesiastic, had thrice, ere he could present it, to change the title whereby he addressed him. Already Dean of Lincoln before Henry VII.'s death (150s), he beame Canon of Windsor (1510), and Dean of York and lean of St. Stephen's, Westminster (1512). He had an unlimited dispensation from the l'ope to hold pluralities. Deaneries were heaped upon him as before benefices, and shortly afterwards, bishoprics as lavishly as deaneries. Bishop of 'Tournay first (151:3), then Bishop of Iineoln (1514), Arehbishop of York (1515), commendator of 
the premier Abbey of St. Alban's (1521), Bishop of I)urham (152:3), and finally, not long before his fall, Bishop of IV inchester. His various and rapid preferments are detailed by Cavendish as follows: "To the increase of his gains he had also the Bishopric of Durham and the Abbey of St. Alban's in commendum; howbeit after, when Bishop Fox of Winchester died, he surrendered Durham into the king's hands, and in lieu thereof took the Bishopric of Winchester. Then he held also, as it were, in ferme, Bath, Worcester, and Hereford, because the incumbents thereof were strangers, born out of this realm, etc. Was never such a pluralist, even in that age. Moreover, in 1515 he received a cardinal's hat (September 11), which was set on his head by Warham in Westminster Abbey (Sunday, is November), amidst an august throng of bishops and abbots. At this imposing ceremony Colet made 'a brief collation or proposition,' and after mention of the new cardinal's 'sundrie vertues,' exhorted him to humility, righteousness, and mercy with truth.* Colet's earnest appeal was as much needed as it was well intended. When the Cardinal of St. Cecilia was also constituted by Papal Bull Legute c lutere (17 May, 1.51s), † he took precedence even of ITarham, and became ruler of the Church.

But Wolsey's ecclesiastical preferments were matched by his high and rapid promotions in the State. He was appointed Chancellor of the Order of the Garter 1512, and the same year, on Norfolk's resignation, Lord Treasurer. Before the close of 1515 he also received the Great Seal, and became (December 22), in succession to Warham, Lord High Chancellor. At the same time, as a member of the Council, he 'had,' it was said, 'the heads' of his fellow councillors 'under his girdle.' He was not only Henry's trusted minister, but his most

* A little before this time a daughter was born to Wolsey. 'My Lord Cardinal caused me to put a young gentlewoman to the monastery and nunnery of Shaftesbury, and there to be professed, and would her to be named my daughter, and the truth is, she was his daughter, ete.' John Clusey, the writer of this letter, put the daughter's age at about twentyfour years at the time he wrote. Tom Winter also was, no doubt, Wolsey's son. It is characteristic that the Cardinal obtained for him, besides great and many preferments, a grant of arms from the Heralds' College.

$\dagger$ Confirmed to Wolsey for life by Clement VII., 24 February, 1524. B. iv., pt. i., 115 . 
intimate personal friend; and relieved him of the toilsome burden of public affairs both at home and abroad. With one hand he held the reins of temporal gorernment; with the other he controlled the Church. He joined large views to the perfect mastery of minute details. His industry was prodigious. by his miversal success-whether he had to plan a pageant, or conduct an intricate diplomatic negotiation, to cndow a college, or subjugate the bench of bishops to his will-he undoubtedly prepared the way for personal government by the sovereign, and for the establishment of the royal supremacy in matters ecclesiastical.

His appearance was commanding, although somcwhat marred by a blemish of the right eye, the memento, it was whisperer, of libidinous irregularities. Gay and facetious, his manners could be at will insinuating or dignified. Although not without a tincture of scholastic theology, he was nevertheless, like the contemporary Cardinal d'Amboise, a man of taste, and devoted to the fine arts. In marvellous versatility and faculty of ready adaptation to persons and circumstances, he eclipsed all his rivals.

A prince of the church, he was yet-strange combinationa patriotic Englishman. He perfectly understood the peculiar position of his own land, and drew to her an importance and prestige wholly disproportioned to her population and power. In political competitions he threw England's weight in the weaker scale, and thus preserved the European equilibrium, and maintained for his country her respected post of umpire. His policy was for the most part pacific. From his settled preference for peace he departed only on exceptional emergencies. Thus, in 1512 , he superintended the formation of the arny with which Henry crossed to the Continent and won the Battle of the Spurs. Foreseeing that the sea rather than the land must be the theatre of his country's greatness, he directed the attention of Henry, himself dextcrous in the shipbuilder's art, to the national duty of forming a sutticient navy. By his advice the Henmy Grace de Dieu, 'of portage 1,500 tons,' huge for that age, was laid (1513) on the stocks; $*$ and although the great ship proved short of a success, it being

* B. iv., part i., 1714. 
planned as it was, did not the less mark Wolsey's long-sighterl policy.

As Lord Chancellor he was enabled to deal a severe blow at perjury, previously the dry rot of our criminal proceedings. He extended the jurisdiction of chancery, or the 'Court of Conscience,' as he preferred to call it, drawing various new causes under its cognisance, so that, 'notwithstanding his despatch, there was generally a great arrear of business.'* 'To meet the increased judicial demand, he created four subordinate courts, of which only one, that of the Master of the Rolls, surrived him, and remains to this day. The lawyers of his time he regarded as imperfectly acquainted with the general principles of jurisprudence; and thus, with his usual grandeur of conception, he projected an institution, to be founded in the inetropolis, for the systematic study of all branches of the law.

No one knew better than Wolsey the low character of clerical morals, of which his own were a humiliating specimen, for he was neither much below nor much above the average morality of the leading ecclesiastics of the period. The degrated condition of the monastic orders was well known to him, and he appreciated the value of converting effete institutions to new and more useful purposes. He desired to have the succession of the throne secured, and then the consistory courts purged, clerieal immoralities restrained, and the monasteries themselves either converted into educational establishments-the great need of the times-or at least restored to befitting sanctity, so as to be efticient garrisons of the Papacy. But the reform of the Church, a Herculean task-from which, however, he did not, like Warham, shrink -he would have accomplished from within, by the Church herself exerting her own recuperative energies. He would have the renovating influence to descend, like the precious oil upon Aaron's beard, from St. Peter's successor, as the fountain head, through cardinals and bishops, to the very lowest skirt of the great papal framework.

It was, on the contrary, God's plan that the plant of truth, striking root in the humble hearts of weavers, artisans, * Campbell's 'Chancellors,' i., pp. 4:30-31. 
mechanies, fishermen, husbandmen, trader's, as in the first dawn of Christianity, should bear fruit, and waft its winged seeds and spread its influence upwards, from the eottage and workshop to the mansion and the palace. And such was, in fact, the history of the early English Reformation. Elsewhere it was otherwise; but where it was otherwise the end was failure. In Italy, amongst the 'illuminati -in Spain amongst 'the friends of light' - the lamp was placed high, and its rays were soon extinguished. Among the upper ranks an evangelical creed may be, and sometimes is, the issue of thought, of taste and refinement. Among the poor and despised it eommonly springs from the real working out in the depths of the soul of the problem of problems, from the strivings of a quickened conscience after peace with God, and the sineere desire to know and to do the Divine will.

Wolsey's schemes were not bounded by the limits of his own island; their compass embraced the extirpation of heresy from German soil. An obedient son of the Church must hold the imperial sceptre; no existing rights could be allowed to interfere with the realization of the grand ideal of the Christian theoeracy. The crowning triumph of his sanguine vision would be himself in St. Peter's ehair, at the head of the theocracy, purified and strengthened.

He was removed from the world before the separation of England from the papacy was aceomplished, and thus perhaps it may be to some matter for eonjecture what his eonvictions would have been, and how he would have acted, if he had been spared in prosperity to the hour when his master distinetly ehallenged the supremaey of the Church in his own dominions against the papaey. But there ean really be little doubt on this point. His devotion to his king and his patriotism were traits in his character certainly more broadly marked than his reverence for the Roman see. His eonfirmed and continued legateship was itself a preparation for England's independence, and his method of obtaining the legateship was signifieant. Campeggio was to be sent to England to ask aid against the Turk. Wolsey informed Leo that the king would only admit Campeggio on two conditions-one, that his embassy should be restricted to the one object of beseeching help against the 
intidel; the other, that Wolsey himself should be joined with him as legate. To this imperious demand Leo submitterl. There can thus be no real doubt that Wolsey, like his protigé Gardiner, would have cordially welcomed the scheme of a national Church under the supremacy of the crown.

His theocratic dream was, of course, in the beginning of the sixteenth century, an anachronism. It was too late for a Hildebrand or Innocent III. The events amid which Wolsey found himself, as time passed on, proved a total surprise to his most cherished fancies. There can be little doubt that the earlier connection of England with Rome-although the missionary zeal, which was a chief instrument in converting our Saxon forefathers, descended southwards from another source, and for some time the nascent Anglican Church looked to Iona rather than to Canterbury - was nevertheless of much national advantage. Besides England being drawn thereby into the great current of European life, the gift of organization, which has always distinguished Rome, was an invaluable communication. Tet at the commencement of the sixteenth century the sun of the day of Rome's potency for good had set sometime since for ever. On questions of theology Wolsey's vigorous mind remained to the last unenlightened. Theology he cared little to study. Grossly superstitious, his piety went little deeper than outside forms. It is as a statesman that he is entitled to all the honour which Englishmen can render. He has been well described by Professor Creighton as 'a political artist.' He hung brooding over his projects as a sculptor or painter over the growing creations of his genius.

Oxford owes a debt of deep gratitude to the great cardinal, who, like Nimenes, aspired to bless future generations by permanent institutions. He induced the king to confirm and enlarge her charters; and when the timid Warham stood aloof, Wolsey girded himself to the enterprise of university improvement and reform. By a papal Bull he converted, with the royal assent (1525), the monastery of St. Frideswide into Cardinal College. The name was changed afterwards to Henry VIII.'s College, a misnomer altogether, for Henry eyed the Church with jealousy in his greed of absolute power. Henry thus swallowed up entirely the other Cardinal College, 
of St. Mary, in the parish of St. Matthew, Ipswich, annihilating every trace of the design, so that only one isolated arch of a gateway remains to mark the site. Of Wolsey's Oxford scheme also the king dwarfed the magnificent proportions.* There were incorporated for the use of Cardinal College, Uxford, forty-one priories and numneries, and all the dependencies belonging to St. Frideswide's were amnexed. $\dagger$ There was much that was reprehensible in the artifices which he resorted to in order to collect the necessary funds; but Wolsey, with a statesman's temper, the end being good, was little scrupulous as to the means.+

The cardinal intended his new foundation to be the chief bulwark and stronghold of the papacy in England. In order to render it the seat of the ehoicest learning and most brilliant talent, he first drew thither all the best scholars that Oxford could herself furnish, and then, through Dr. Capon, attracted thither also the finest wits from Cambridge. Of the colony thus imported from Cambridge there was scarcely one individual in whom love for the Holy Seriptures did not burn like a tire. Thus Wolsey himself, when he would fain have aggrandized the papacy, proved the instrument in higher hands for the introduction of a purer faith.

It shows how deeply Cambridge was imbued with the principles of Holy Writ, that her able alumni transferred to Gxford were almost all Gospellers. Thus the light of pure religion was kindled, or, rather, rekindled, among the colleges and hostelries on the Isis. Foremost from among those

* 'Surely,' the king replied (August 2.2, 1530) to Higdon and Carter, when they sued for the college, "we purpose to have an honourable college there, but not so great and of such magnificence as my lord cardinal intended to have ; for it is not thought meet for the commonweal of our ralm; yet will we have a college honourably to maintain the service of (rod and literature.'-B. iv., part iii., 6579).

$\dagger$ Bull for suppression of St. Frideswide's was dated 3 Non. April, 1524. See B. iv., part i, 649, (6,0). License to found the Ipswich Cardinal's College bears date .June 29, 1528.-B. iv., part ii., 4435.

+ See Knight's letter to Wolsey, August 19, 1527.- B. iv., part ii., 3:3it). To give one suggestive instance out of many, Northumberland writes (August 3, 152 $\times$ ) to his cousin, Thomas Arundel : Bedfellow. . . if the cardinal will give me leave to put William Worm into a castle of mine at Anwyk (that is, in prison) until be has accounted for more money than ever I received, I will give him $\$ 200$, and a benefice of $: 100$ for his college. - B. iv., part ii., 4603 . 
drafted from Cambridge was John Clerk, canon of Cardinal College, older than the rest, and more mature in scholarship. Clerk in his new sphere did not forsake his Cambridge habits, but proceedeu to 'read in his chamber Paul's epistles to young men, and those who were of two, three, or four year's' standing in the university.'* Like Bilney at Cambridge, so Clerk at Oxford extended his ministrations to the poor of the town. His efforts were systematic and unintermitting. We are chiefly indebted for what we know of his labours to Anthony Dalaber, of St. Alban Hall, a warm-hearted adherent.

Dalaber relates that he implored Clerk to suffer him to go with him 'continually, when and wheresoever he should teach or preach.' Clerk warned him in reply that persecution would be sure one day to fall upon the true doctrine and its maintainers. Dalaber fell down on his knees at his feet, and "with tears and sighs besought him for the tender mercy of God" not to refuse him. 'I trust,' he said, ' that he who Has begun this in me will not forsake me, but give me grace to continue therein to the end.' Clerk took him in his arms, kissed him, and said, "The Lord Almighty grant you so to do, and from henceforth ever take me for your father, and I will take you for my son in Christ.' Tery useful were Dalaber's services in distributing books amongst the students. If any failed to be present at the Scripture readings, Dalaber would visit him in private, hear his doubts and difficulties, and carry back words of counsel from Clerk.

Thus was there formed at Oxford, through the unwitting instrumentality of no other than the great cardinal himself, in the centre, where he had hoped to plant a commanding papal garrison, a knot of Scripture students, united as brethren in Christ, trained in the Scriptures, and ready to take their part, with intelligence as well as zeal, in the conflict that was already waging.

It was in the teeth of his own plain intent, through the providence of an infinitely more far-seeing eye and stronger arm, that Wolsey helped forward the Reformation. Yet it must be allowed, notwithstanding his zeal for Rome, that he was not generally a cruel persecutor. The full vigour of his

* London's letter to Longland, B. iv., part ii, 3968. 
mind was concentrated on polities, and he had less lcisure than other prelates for burning heretics. It is as a statesman that he was emphatically the right man, raised up at a critical juncture, to achieve a great national work. Foreign aftairs especially invited and received his keenest attention.

Had there been no Wolsey, could the England of to-day ever have grown up, at least so as to reach her preseint stature and strength? Stripped of her continental provinecs, prostrated by long intestine bloodshed, the ravages of civil war having been only less desolating than the Black Death a century before, England was in perilous waters when the butcher's son of Ipswich was summoned to the helm. Modern England, in fact, with all her latent powers for good or evil, was in the humble cradle at that momentous epoch. And if it be permissible to carry the eomparison a little farther, it was Wolsey who proved the foremost, most capable, and most clear-sighted nurse, that in scarlet hat and tippet of 'rich sables' diligently watched over the fretful and wayward intant. 
BOOK III.

THE ENGLISH NEW TESTANENT.

\section{I.-WILLIAM TINDALE'S PREPARATION.}

The central figure in the early period of the English Reformation is William Tyndale, 'the Apostle of England in these later times,' as Foxe designates him. His native land, for the enlightenment of which with pure Christian truth he perseveringly toiled as long as he lived, and at last suffered martyrdom, apperred sealed impenetrably beyond other lands against the Word of God. Luther flourished among the Saxons, Zuingle among the Swiss; but Tyndale, by the bitter hostility which the rulers of his country entertained against the principles of the Reformation, was driven, almost as soon as the purpose of his life was settled, to the refuge of a foreign shore, carried on his labours for the salvation of his countrymen among strangers, and, in order to baffle pursuit, was forced to resort to various precautions which, besides concealing his movements from lis persecutors, have in large degree shrouded them from posterity.

William Tyndale, according to the statement of Foxe, was 'born about the borders of Wales.' Nor did the prevalent belief that he was born in Gloucestershire differ from this vague statement, for formerly Monmouthshire, separated from Gloucestershire by the Severn, was included in Wales. At length, not only the village of Gloucestershire, but the very house itself, wherein the translator of the Scriptures into homely English first saw the light, became marked out and determined to the curious public. Hunt's Court, in the parish 
of North Nibley, came to be visited by admiring pilgrims as the very birthplace of William, the illustrious translator and reformer, the second son, it was said, of Thomas and Alicia Tyndale.

The situation is pieturesque and inviting, the house itself not equally attractive; but during the course of four centuries it has undergone, no doubt, mueh ehange. A portion of it has been eonverted into an inn, known by the name of the Black Horse; and a representation of this quadruped of the size of life is plaeed under the eaves of the middle of the three gables of the long one-storied building, which in ancient days formed a single commodious dwelling-house. Gazing upwards towards the Cotswolds, the eye diseerns at onee at little distanee the Tyndale Nemorial, erected by subseription on Nibley Knoll-a tall, square pile, withont inseription, with a gilded cross on the summit. Indeed, a stone rolled down from the hill-brow might easily find a resting-place just in front of Hunt's Court.

It was a pleasing fancy that the future Reformer played as a boy on the green hillside, climbed up the round chalky knolls, or wandered on the breezy ridge of high land which looks down on the beautiful country about Wotton-underEdge. This fancy, however, can be no longer indulged. Recent researehes have made it elear that Hunt's Court did not become the property of a Tyndale so early as $1454-86$, which must be about the time of the Biblieal translator's birth; and it has been likewise proved that William, the son of 'Thomas and Alieia Tyndale, of Hunt's Court, was alive in 1.54 , and therefore eannot be identical with his more distinguished kinsmin of the same name.

It is thought probable by Demaus* that 'the Apostle of England' was born, not at Nibley, but at Slimbridge. Either Slimbridge or Stineheombe was, in all probability, the Reformer's aetual birthplace. Not only had there been Tyndales established as farmers at Melksham ('ourt, in the neighbouring parish of stineheombe: but in the reign of Riehard III. Tyndales had possessed some part of the Manor of Hurst, in slimbridge. A letter is extant from Stokesley, Bishop of

$$
\text { * Demaus' 'Tyndale,' ip. 3, 4. }
$$


London, to Crumwell, wherein he solicits a farm in Gloucestershire (Greene Hampster) for an old friend. A Tyndale, however, had made application for the same farm; and Stokesley remarks: "He that sueth unto you hath a kinsman called Elward Tyndale, brother to Tyndale the arch-heretic, underreceiver of the lordship of Berkeley, who daily promotes his kinsfolks to the king's farms.* Stokesley in 1509 was Rector of Slimbridge, a benefice in the gift of Magdalen Collegre, Oxford, and thus was no doubt personally acquainted with the Tyndales of his parish and neighbourhood. The Edward Tyndale referred to was a man of substance and ability, and is proved by his will to have been possessed of a book ('Pellicanus on the Old Testament') prohibited as heretical, on which he set some value.

The name of another brother, John, appears (1531) amongst those who were punished for assisting in the circulation of the New Testament. It seems to have escaped the researches of biographers that there was also a third brother, named Martin, a Fellow of King's College, Cambridge. Letters, however, are extant from Martin Tyndale (dated July, 15:3:3) to his brother Edward's friend Crumwell, in one of which he expresses gratitude for kindness shown to his 'brother John (now departed) in his troubles.' Martin himself is a scholar, like the Reformer, and offers to Crumwell some fruits of his industrytranslations of the lives of John Colet and Jehan Vitrier, the Franciscan of St. Omer, two companion portraits, disinterred from a corner of the 'Epistles of Erasmus.' 'Crumwell's approval,' he says, 'will be a prick to him to be better willing to go forth in like harvest work; wherein he trusts so to temper himself that he will refrain from rash meddling with things that pass his learning;' but yet he purposes 'not to flatter the peevish popish, that for fear of their displeasure hes will make white their black and abominable acts.' $\dagger$

Of the father of these four sons all that is at present known

* Dated Fulham, January 26 (1533). In another letter, after an interval of three days, Stokesley rejoins, 'If magre my head, Edw. Tyndale should put my servant from that grant, my friends would think that he had more influence with you than I, etc.-B. vi, $4: 2,9 \%$. 1iy bequest the Berkeley estates, in 1492 , came to the crown.

$\dagger$ B. vi., $751,75 \%$. 
is comnunicated in a letter of the same Martin, who, in soliciting Crumwell's help 'against the unkind lady revía (joverty),' recounts: 'When I was first sent to school, my parents were able enongh to keep me there, as who were wellnigh under the high walls of glittering worldly riches; but a while after (the wheel of fortune turned), sooner than a man would have thought, they were defeated, and put back to such penury that they could not so largely as before bear my charges at school. Here Dr. Denton, Dean of Lichfield, parson of St. Olare's, Southwark, of whom my futher furmed the same benefice, got me to Eton College, where, and at Cambridge likewise, to this year he has yearly given me his liberality and paid the stipend of the college. 'This year he died,' ete.

The fact of four sons all favouring the Reformation suggests the question whether the parents themselves may not have inelined to the tenets of IVyeliffe-a conjecture supported by the tradition that one of the barons of Berkeley was IYyclifte's pupil. Thus a fresh link is established, it may be, between the successful Reformation, in the early career of which Tyndale played the principal part, and the apparently unsuccessful movement one hundred and fifty years previously under the apostolic Wycliffe.

The origin of the Gloncestershire Tyndales is probably correctly given in a letter (dated February 3, 166:3)* from a Thomas Tyndale to a cousin and namesake: 'I have heretofore heard that the first of your familie eame out of the North in the times of the wars between the houses of York and Lancaster, at what time many of good sort (their side going down) did fly for refuge and suecour where they could find it. That it was your predecessor his fortune to come into Gloucestershire, changing his name into that of Huchins; and that afterwards he married there, and so having ehildren, he did before his death declare his right name,' etc.

Once, and once only, the Reformer makes allusion-a very characteristic allusion-to his boyhood in his writings: 'Except my memory fail me, and that I have forgotten what I read

* See Offor's ' Bingraplyy of Tyndale' prefixed to his reprint (1836) of the one perfect copy of the first New Testament version in the octaro; also the biographical notice prefixed to Tyndale's works, P.S. 
when I was a ehild, thou shalt find in the English Chronicle how that King Adelstone eaused the Holy Seripture to be translated into the tongue that then was in England, and how the prelates exhorted him thereto.'

The county of 'Tyndale's birth was in that age beyond measure benighted and priest-ridden. Yet, amidst dense darkness-darkness that might be felt-light, in God's mereiful providenee, had been lifted up in the preeeding century. The fifth baron, Thomas, Lord Berkeley, Wycliffe's pupil, had as his own ehaplain, and also as vicar of his parish church, John de Trevisa, who, at the request of his patron, to whom he was a compliant and, to quote his own phrase, 'buxom' servant, translated into English the 'Polychronicon' of Ranulph Higden, a Benedictine monk of St. Werburg, Chester, who flourished at the elose of the thirteenth century. 'The "Polychronicon' was the ehief source of information in listory and geography - for it embraced both—to English students for the two next eenturies. 'Trevisa's translation was 'emprynted,' with alterations, by Caxton, who states that Trevisa translated 'this sayd book, the byble, and Bartylmew de proprietatibus rerum.' As regards the translation of the Bible, the eelebrated printer must have taken the will for the deed. Trerisa aspired to an achievement to which his scholarship would have been unequal, for his version of Higden contains several gross blunders. The Vulgate was translated by others better qualified for the task. It is as a writer of English that 'Trevisa's versiont of Higden's 'Universal History' is very acceptable to the philologist. It was aceomplished in 1387, and thus elosely followed Wyeliffe's version of the Scriptures in point of time. It long remained a popular book. Amidst darkness, not diminishing, but rather augmenting, there was food for meditation in memories such as these, well adapted to eall forth and quieken the energies of a youthful, ardent mind.

William Tyndale was probably yet a lad when he eommeneed his studies at Oxford-'brought up even as a child,'

* Preface to 'The Obedience of a Christian Man.' Tyndale's Works, P.S., i., p. 149 .

$\dagger$ Edited by Churchill Babington, with an introduction. 
says Foxe, 'in that university.' Cranmer was sent to Cambridge at fourteen year's of age; Wolsey was no older when he took his Bachelor's degree. In that age the universities were rather high schools, possessing advantages beyond the monastie schools, than what they have since beeome. Magdalen Hall, now Hertford College, was Tyndale's training-sehool. His portrait adorns its dining-hall. It had been intended by its founder, William Wayneflete, as a nursery to his nobler foundation of Magdalen College, and so well did it answer this purpose as to gain and deserve the appellation of Grammar Hall. Stokesley became prineipal early in the sixteenth century (1.502), and was succeeded in the post by Longland.

Of his career at Oxford, Foxe has left us only this short summary: 'Tyndale, by long continuance, grew up and inereased as well in the knowledge of tongues, and other liberal arts, as especially in the knowledge of the Scriptures; whereunto his mind was singularly addieted, insomuch that he, lying then at Magdalene Hall, read privily to certain students and Fellows of Magdalene College some pareel of divinity, in. strueting them in the knowledge and truth of the Scriptures.' This information was probably given to the martyrologist by Coverdale, who may have received it from Tyndale himself; and it must not, therefore, be lightly rejected.

Tyndale's stay at Oxford was protracted. In accordanee with enstom, two years and a half must be allowed to the trivium, or grammar, rhetoric, and logic. Then two years and a half must be allotted to the quadrivium, or arithmetic, geometry, astronomy, and music. Then the approach lay open to the three philosophies-natural, moral, and metaphysical. Thus nearly eight years would be oeeupied in the studies requisite for the degree of Master of Arts. Wide as the compass of linowledge appears, our estimate of its value very much shrinks when the books in use are taken into the account.* Then sacred study would engross, under its two stages of Biblieal and systematic theology, seven years.

That Tyndale took his Master of Arts degree is certain; but little more is known of lim in relation to his Oxford eourse as 
a positive fact. That he attended Colet's lectures and derived benefit from his historical system of interpreting Scriptureas opposed to the prevailing scholastical method-is rendered highly probable by the most patent characteristics of 'Tyndale's mind. That he was blindly fascinated by the reputation and genius of Erasmus is beyond a doubt.

It is matter for conjecture in what year he removed to Cambridge. Erasmus is supposed to have been the magnet. If so, the date of Tyndale's removal is probably 1509, or soon afterwards, although Erasmus had before visited Cambridge in 1506, during his second visit to England, but then only for a brief space. But it is now clearly ascertained that Tyndale had a brother at King's College ; and to be with him and aid him in his studies would alone supply sufficient reason for the migration. Colet was probably an influence for good at Oxford ; and at Cambridge there can be little ground for doubting that the guiding-star was the devoted Bilney.

How Tyndale was able to maintain himself during his long course of assiduous study is an inquiry which naturally arises, for a satisfactory reply to which few materials exist. Was Tyndale's father like Latimer's, the Leicestershire yeoman, of whom his son said in a sermon before the Court: 'He kept me to school, or else I had not been able to preach before the king's majesty now'? It seems, however, that after a time his father's circumstances became straitened. Had Tyndale, then, like Wolsey, liberal friends? If so, he resembled in this respect his brother Martin, who acknowledged his obligation to benevolent assistance for his own education.

A university career in that age was not luxurious and costly as it is now. Three or four youths would sometimes be placed together in the same straw-littered apartment. The hostels and religious houses much outnumbered the colleges, although these last were growing in importance. The aggregate of the members of the several institutions was large, and many were in humble and even depressed circumstances. Their frequently necessitous condition is proved by two facts-that the university itself undertook the office of pawnbroker, advancing money on a deposit, and that students returning home from their studies were often licensed to beg at the houses of the 
wealthier elass, and were thus enabled to support themselves on their footsore journey.

But of the peeuliarities attending the future translator's sojourn, whether at Oxford or Cambridge, we know next to nothing. No doubt his habits, even at this early stage, were extremely frugal. After a time he would derive some emolument from tuition. Indeed, almost the only additional fact known with absolute eertainty relative to his long university career-commmicated by his own pen in a letter to Frythis that he had a pupil, John Tisen by name, afterwards in Timstal's service, whose 'red beard and black reddish hair'* he observed in after-years at Antwerp, not without some fear and suspicion.

At least it is beyond doubt that his persevering diligence was rewarded, and that he left Cambridge 'a scholar, and a ripe and good one.' It is eertain also that he was ordained priest, but when, where, or by whom are points involved in hopeless oblivion. On Offor's supposed discoveries no reliance ean be placed. 


\section{II.-TYNDALE AT LITTLE SODBURY.}

About 1521 Tyndale comes upon the seene with clearer prominence in the character of the studious priest of a small parish in the neighbourhood of his home.

Sir John Walsh, of Little Sodbury Court, champion to Henry VIIl., and in 1526, and again in 1535, High Sheriff of Gloncestershire, required a chaplain for his house, a priest for his parish church, and a tutor prospectively for his little son Naurice, , then, it would seem, five or six years old. Tyndale, on his part, accepted the combined duties, and took up his residence in Sir John's mansion.

The court, or manor-house, stands under the brow of Little Sodbury Hill, an eminence distinguished to the traveller's eye by its clumps of beech-trees. A Roman campcrowns its summit, and here Edward IV. lay one night with a part of his army a little before the battle of Tewkesbury. The house is built on terraces, and is a good model of a country gentleman's seat of the Tudor period, although now partly converted into a farmhouse and partly untenanted. The right wing, with its projecting gables, is a storehouse for planks, and is used also as a carpenter's shop. The left side of the house is inhabited, but is in deplorable dilapidation, the roof propped with uprights. In 1608 the manor-house passed from the Walshes to the family of Stephens. It next passed to Mr. Hartley, resident at Lygrove, about a mile distant, who stripped it of such memorials of antiquity as he could remove, and left the old

* The fate of Maurice was melancholy. 'In the year 1556, in less than two months, died Maurice Walsh, Esq, together with seven of his children, by a fiery sulphurous globe rolling in at the parlour door at dinner-time, which struck one dead at the table and caused the death of the rest.'-Atkyn's 'Gloucestershire,' folio, p. 354. 
mansion to fall into decay. Tyudale's room, which was connected with the hall, has disappeared. It was pulled down, together with other parts of that seetion of the house, some years ago to furnish materials for repairing cottages. St. Adeline's Chureh, wherein Tyndale ofticiated, which stood on a terrace above the house, was taken down in 18.5s. some stones and two fine yew-trees remain to mark the site.

If the visitor take his stand on the grass platform in front of the old porch of the manor-house, he will see to the right an oriel window, and to the left, in a reeess, the iron bars of the windows of the lofty dining-hall, long sinee without glass, and mantled with ivy. Entering the ancient hall, his faney will hardly fail to transform the present dismantled scene and to picture Tyndale, a short, grave person, with elose-elipped beard, aquiline nose, high, full forehead, and large eyes, about thirty-six or thirty-seven years of age, seated as he often was rather more than three hundred and fifty years ago at the oak table, with the New Testament of Erasmus open before lim.

'This is 'the most heart-stirring spot,' says Anderson, 'in all England.' It is here that Tyndale had many conversations on religion with Sir John and Dame Anne, his wife, the daughter of sir liobert Pointz, of Iron Acton, and granddaughter of the accomplished Lord Rivers, beheaded at l'ontefract by Richard III. Here also he had many controversies with priests of the vieinity, mumpsimuses* of divinity, whom he has deseribed as 'wont to look on no more of Scripture than they found in their Duns.' 'God it knoweth,' he afterwards wrote, 'there are a full ignorant sort, which have seen no more Latin than they read in their Portesses and Missals, which yet many of them can scarcely read, except it be Albertus de secretis mulierum, etc.t How angry grew their faces when Sir John's studious chaplain exposed their gross ignorance: Here, too, it was that he eneountered some more subtle disputants, and by all he heard and saw was led to meditate

* See Richard Pace's anecdote, 'Narratives of the Reformation,' C.S., p. 141 ; and skelton's amusing doggerel in the Appendix.

+ Preface to the Five Books of Moses, Tyndale's Works, P.S., i., p. 94. 
more and more on the true means of enancipating the benighted heart and perverted intellect, and arriver at the conclusion that the only way to get rid of their 'imaginations and juggling terms' was to translate the Scriptures into English. He afterwards wrote: 'As long as they may keep that (the Seripture) down, they will so darken the right way with the mist of their sophistry, and so tangle them that either rebuke or despise their abominations with arguments of philosophy, and with worldly similitudes and apparent reasons of natural wisdom, and with wresting the scripture into their own purpose clean contrary unto the process, order, and meaning of the text, and so delude them with descanting upon it with allegories, and amaze them, expounding it in many senses before the unlearned lay-people, when it hath but one simple literal sense, whose light the owls camnot abicle, that though thou feel in thine heart and art sure how that all is false that they say, yet couldst thou not solve their subtle riddles. Which thing only moved me to translate the New Testament.'

It is not surprising, then, that the happy footing on which Tyndale had stood with his patrons was disturbed by the sly whispers or overt denunciations of the maintainers of the oid scholastic system and its pretentious sophistries. He found himself alone among a host of opponents, all banded together as interested in one common cause against him, the network of their ministrations and influence extending far and near. Friars, monks, priests, dignitaries, spoke of him in similar terms of bitter dislike. Foxe relates t that in particular at a 'supper' banquet,' at which Sir John and his lady were among the guests, 'beneficed doctors' talked against their chaplain 'at will, without any gainsaying.' On their return home 'Tyndale was summoned before his patrons, and was "informed of such communication as had been where they came from and of their opinions. Master 'Tyndale thereunto made answer agreeable to the truths of God's word, and in reproving of their

* Preface to the Fire Books of Moses.

$\uparrow$ In the edition of 1513 , the first account in English. The report came from one who knew Tyndale, probably Richard iVebb, of Chipping sodbury, afterwards servant to Latimer. 
false opinion. The Lady Welch, being a stout woman, and as Naster Tyndale did report her to be wise, being there but no more than they three, Master Welch, his wife, and Master Tyndale-" Well," said she, "there was such a doetor, he may dispend two hundred pound by the year, another one hundred pound, and another three hundred pound, and what think ye, were it reason that we should believe yon before them, so great and benefieed men?" In return Tyndale said nothing, but shortly afterwards presented to the knight and his lady a translation into English of a work of Erasmus, which at the time was very popular-' The Christian Soldier's Poeket-dagger.'*

This work, originally written in 1501, had been reissued in $1.51 \mathrm{~s}$, when the controversy between Luther and Rome was beginning to engross attention. Its new preface, fraught with a vigour and tire above the usual strain of Erasmus, as if at so momentous a erisis the manliness of Luther had influenced and transformed the timid scholar, proved especially aeceptable. Tyndale's translation of this work, which had now become popular, well served the object which he had in view. The authority of Erasmus was generally recognised, and the 'doctorly prelates,' welcomed less heartily from this time forward at the manor-house, became more sparing of their visits, and 'at last ntterly withdrew themselves, and eame no more.'

Apart from the effect produced on Sir John and his lady, there are observations in the 'Enehiridion' which must have sunk into the very soul of one who was meditating the translation of the Seriptures into English, and must have helped to prepare him for that great work, stimulating and guiding him to embark in it in the right temper. 'Remember again and again,' wamed Erasmus, 'that Seripture must be handled with

* 'Militis Christiani Enchiridion,' vol. v., pp. 1-60. Erasmi Opera, folio, Leyden, 170:5. 'The treatise had been composed 1501, at the Castle of Tormahens, near St. Omer, to influence for good a bad husband, at the snggestion of his wife, Erasmns' fellow-guest. 'Whilst for years after it was written, it was known only in select circles, and was far from being a popular book, yet no sooner had the Protestant movement commeneed, than, with a fresh preface, it passed through almost innmmerable editions with astonishing rapidity. Nor was it read only by the learned. It was translated into English by Tyndale, and again in an abridged form reissned in English by Coverdale. And whilst in this country it was treated almost as a Protestant book, so in Syin also it had a remarkably wide circulation.'- Seebohm's 'Oxford Reformers,' second edit., p. 174. 
washed hands - that is, with the utmost purity of mind. Let not the antidote through your fault tmin to poison. Let not the mamna from heaven breed worms and stink. Receive it into your heart of hearts, and live upon it. Je not like Uzzal, who put forth a profane hand to stay the tottering ark. First of all, think worthily of the Holy Scriptures. Pure oracles are they, proceeding from the shrine of the Divine mind. Approach with humility and awe, and in wondrous sort you shall be transfigured. You shall behold the joys of the blessed bridegroom, the riches of the wealthiest Solomon, the hidrlen treasures of Eternal Wisdom. But take heed; rush not into the sanctuary. The portal is lowly; bow yourself to the ground ; strike not the lintel with your head.'

In proportion, however, as Tyndale grew in favour with sir John and Lady Walsh, the hatred and aceusations of his enemies became more intense and loud. It had not mitigated their antipathy that he hard chiller for them the hospitality of Little sodbury. 'The priests of the country,' clustering together in knots, began to storm and rave against him inore fiercely than ever. He was denounced as a heretic by them without a voice of contradiction over their tankards in the ale-house, which, said 'Tyndale, was 'their preaching-place.'

At length allegations against him were lodged with Dr. Parker, the chancellor of the diocese, recently raised to that dignity. The Bishop of Wrorcester, in whose diocese the county of Gloncester was then included, was an Italian, resident at Rome. Indeed, at this period three Italians in succession were bishops of the rich See of Worcester: Sylvester de Gigliis (Sylvestro de' Gigli), who retired to Rome, 1512; and on his death, 1.221, Julio de' Medici, afterwards Clement VII. ; and then, on his resigning the see within less than a year, Jerome de Ghinucei, auditor of the apostolic chamber, much employed by Henry VIII. as a diplomitist. In fact, the bishopric was a retaining fee, for service to be rendered to the English Court; and Wolsey himself farmed the revenues for the Italian absentee. But it would have been idle for 'Tyndale's adversaries to make their representations to one so immersed in multifarious business as the Cardinal Legate. 'They therefore repaired to Dr. Parker, and rented 
their eomplaints in full volume into an ear quite ready to receive them. This is the dignitary who subsequently earned notoriety by exhuming and huming the bones of William Tracy, of Todelington, without so mueh as waiting for the king's writ, in obedience to Convocation, for which illegal haste, aceording to Hall, a suit was instituted against him two years afterwards by Mr. Riehard Tracy, with the result that he was fined the large sum of three hundred pounds. Parker appointed a day for Tyndale and the clergy of the diocese to appear before him. Well did Tyndale know that his antagonists had been sedulously at work behind the seenes; and as he was going to the chancellor he "prayed in his mind heartily to God to strengthen him to stand fast in the truth of His word.'

The reformer's own pen has related the result. "They (the priests of the eomntry) affirm that my sayings are heresy; and besiles that, they and to of their own heards which I never spake, as the manner is to prolong the tale to short the time withal, and accused me seeretly to the chancellos; he threatened me grievously, and reviled me, and rated me, as though I had been a dog, and laid to my eharge whereof there eould be none aceuser brought forth (as their manner is not to bring forth the accuser), and yet all the priests of the country were the same day there." The ontcome of the examination was merely fruitless reviling and threatening of 'Tyndale, who 'thus departed home.'

'There dwelt not far off a eertain doctor,' Foxe narrates, "who had been of old familiar acquaintanee with Mr. Tyndale, and also favoured him well, unto whom Mr. Tyndale went and opened his mind upon divers questions of the seripture; for to him he durst be bold to disclose his heart.' This doctor Anderson eonjeetures to have been IVilliam Latymer, the Oxford (ireek scholar, 'retired as Rector of Weston-sub-Erlge.' '1) yon not know; the doctor exclained in answer to Tyndiale's inquiries, 'that the Pope is very Antichrist, whom the seripture speaketh of? But beware what you say, for, if you shall be pereeived to be of that opinion, it will cost you your life. I have been an oftieer of his, but I have given it up,

* Preface to the Five Books of Moses, Tyndale's Works, P.S., i., p. 39.5. 
and defy him and all his works.' This interview marks an important onward step in Tyndale's mental and spiritual development.

Not long afterwards he was engaged in argument with an opponent, who enjoyed the repute of learning, who blasphemously asserted, "We were better to be without God's laws than the Pope's:' 'I defy,' retorted Tyndale, using the expression of the doctor, his old familiar, ' the Pope and all his laws; and if God spare my life ere many years, I will cause a boy that driveth a plough shall know more of the Scripture than thou doest.'

'After this,' Foxe proceeds, 'the grudge of the priests increasing still more and more against Tyndale, they never ceased barking and railing at him, and laid many sore things to his charge, saying that he was a heretic in sophistry, a heretic in logic, a heretic in divinity; and said, moreover, that he bare himself bold of the gentlemen there in that country; but, notwithstanding, shortly he should be otherwise talked withal.' 'I am content,' Tyndale professed, ' to go into any county in England, with ten pounds to live on, and bound to no more than to teach children and to preach.'

He became more and more convinced that his stay at Little Sodbury must be brief. 'I was so turmoiled in the country where I was,' he afterwards wrote, 'that I could no longer dwell there.' Still, he could not without some feclings of regret, quit a spot where he had spent two or three years of study and meditation; of controversy, too, with opponents, which, if void of any other good effect, had at least served to give greater clearness to his own religious convictions; where, moreover, the persistent resolve of his life had been formed, and his character had become matured and fixed. His evangelizing zeal had led him far beyond Sodbury; he had preached 'about Bristol,' then the second city in the kingdom, 'and also in the said town, in the common place called st. Austin's Green,' and had been gladly listened to by many. The knight and his lady had treated him with kindness, that had known but short intermission. Converse, moreover, with Tracy of Toddington, whom he has himself commended as ' $a$ learned man, and better seen in the works of Austin twenty 
years before he died than ever I knew doctor in England,** and oceasional references of various ditticulties to the "old familiar' spoken of by Foxe, whose deliberate judgment om the Papacy had opened a flood of elearer light, had not been without real help and comfort. He could never forget Sodbury. But it had been made quite plain to him that its Manor House was not the place wherein to translate the Word of fod in peace; and to this enterprise he had consecrated his days. Walking the hill above its green terraces, pacing its hall, sitting at the oak dining-table, in the solitude of his own apartment, one thought and purpose had so filled his soul as to become a rooted determination, over-mastering every secondary scheme, to translate the Seripture from the inspired originals with strict fidelity into plain homely English, such as the most unlettered could understand.

He therefore 'required his Master Welch of his good will to depart from him, saying to hin, "Sir, I perceive that I shall not be suffered to tarry long here in this comtry, nor you shall be able to keep me out of their hands; and what clispleasure you might have thereby is hard to know: for the which I should be right sorry.",

Leaving, therefore, Little Sodbury, he proceeds up the steep hill at the back, and on the summit turns for an instant to take a firewell look on the fair valley he is quitting, dotted with gray, weather-stained abbeys, with church towers and stone mansions, and enriched with the autumn foliage of woorls and hedgerow trees, the panorama bounded by the Severn and the Welsh mountains. He then sets his face resolutely towards the Metropolis with a heart not devoid of hope. It is the autumn of $1.523 .+$ The jomney must be aceomplished on foot. Loeal tradition, by a fiction suggested by facts, represents his persecutor's in angry seareh, and Tyndale escaping by the door of the library into the flower-garden on the north side of the house, thence by the gate up the hill, and by nimble flight eluding his pursuers.

* Exposition of Tracy's Testament, Tyndale's Works, P.S., iii., p. 270.

F The date is determined pretty elosely by a letter from Monmouth fom the 'Tower, 1! May, 152': 'I did give an exhibition unto a priest called sir William 'Tyndal, alias Hotehens . . Y Yon four years and a half past and more, I heard the aforesald Sir William preach two or three scrmons at St. Dumstan's-in-the-West.'-13. iv., part ii., 4ะ8:. 
WH.t he should do on reaching London had been already planned by Tyndale. Erasmus, then a type not only of literary, but also of moral and spiritual excellence, to his fancy-of whom, however, five or six years later, in his 'Preface to the Five Books of Moses,' he wrote, 'He maketh of little gnats great elephants, and lifteth up above the stars whosoever giveth him a little exhibition, had lavished encomium on Tunstal, who had quite recently succeeded the persecuting Fitz-James in the See of London. FitzJames hat been a violent Scotist, and had accused Colet to Warham of objecting to the worship of images, of disdaining the notion that Christ's admonition to Peter, 'Feed My flock,' could mean worldly ways of entertainment, and of condemning 'reading sermons in a cold, unaffected manner,' such as was the habit of Fitz-James himself. The failings and incompetence of such a predecessor served as a foil to the accomplishments and worth of Tunstal, who had, moreover the repute of being a good Greek scholar, having studied the language under able teachers in Italy.

To such an admirable prelate, then, and liberal promoter of learning, Tyndale will betake himself; will become his chaplain; and will translate the Testament of Christ 'even in the Bishop of London's house.' What spot more appropriate! He was indebted to Sir John Walsh for a letter of introduction to his friend, Sir Harry Gilford, or Guldeford, 'the king's grace's comptroller,' who had served under Ferdinand and Isabella against the Hoors in Spain, and now enjoyed much favour with his royal master. Tyndale brought him-for he was a man of reading as well as a soldier - an oration of Isocrates, translated out of Greek into English, 
a sample of his Greek scholarship. Sir Harry promised Tyndale to speak to 'Tunstal in his behalf; 'which,' as the Reformer has related," he also did, as he showed me, and willed me to write an epistle to my lord, and to go to him myself; which I also did, and delivered my epistle to a servant of his own, one William Hebilthwayte, a man of mine old acquaintance.'

But the hope of quiet studious leisure for a momentous achievement in an episcopal palace, too lightly raised, was doomed to speedy disappointment. Tunstal answered that ' lis house was full; he had more than he could well find;' and advised one so highly recommended to 'seek in London, where he could not lack a service.' For the moment Tyndale was downcast; but ere long acknowledged that he had reason to thank God for averting a step which would have proved a hindrance, not a help. 'God, which knoweth what is within hypocrites, saw that I was beguiled, and that that comsel was not the next way unto my purpose; and, therefore, He gat me no favour in my lord's sight.' Providence had prepared for him in his perplexity a more congenial friend and patron, a worthy merchant, residing in the extreme east of London, in the parish of 'All Saints,' Barking. For, even if theological differences could have been set aside, what real sympathy could there ever have been between the bold, ontspoken enthusiastic Tyndale, and the taciturn, worldly-wise, courtly 'Tunstal ?'†

This sincere friend, Humphrey Monmouth, belonged to a cliss raised to wealth by the extension of commerce and their own persevering enterprise; men who were destined to aid the Reformation of the sixteenth century as zealonsly and more effectually than the knights had aided Iyeliffe's movement. Commerce had brought English merchants into contact with the free burghers of the Hanse-towns and the busy traders of the Netherlands; and the circle of ideas had enlarged with the circle of outward life and interest. In his zeal for Christ, Nonmouth harl even made a pilgrimage to Jerusalem; and

* Preface to the Five 13onks of MIoses.

$\dagger$ Tyndale afterwark called 'Tunstal, 'that still saturn, the imagine' of all imischief.-Tyndales Works, P.S., ii., pp. 3:21, 337. 
out of his large wealth-for he usually sold ' 400 or 500 cloths every year to foreigners' - he had purehased 'pardons a punt.

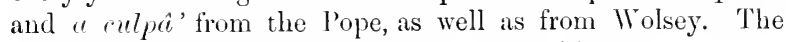
introduction was due to 'Tyndale's preaching one or two sermons at St. Dunstan's-in-the-West; Monmouth was one of the eongregation and listened with pleasure and protit. 'After that,' Monmouth himself recounts in his petition to Wolsey and the Couneil in his subsequent troubles, " I chaneed to meet with him, and was told by him that he had no living, but he trusted to be with my lord of London in his service; and therefore I had the better fantasy to him. And, afterward, he went to my lord of London, and spake to him, as he told me; and my lord of London answered him that he had ehaplains enough, and he said to him that he would have no more at that time. And so the priest came to me again, and besought me to help him; and so I took him into my house half a year, and there he lived like a good priest, methought; he studied most part of the day and of the night at his book; and he would eat but sodden meat by his good will, nor drink but small single beer. I never saw him wear linen about him the space he was with me.' Thus Tyndale acted out with consisteney his own subsequent preeept, that 'every man must tame his flesh with prayer, fasting, and the continual meditations of Christ's penance and fastings for us, and of the holy saints; and with such abstinenee and kind of living as every man thinketh most meet for his eomplexion.' +

'In London,' Tyndale has himself narrated, ' I abode almost a year, and marked the course of the world, and heard our priters-I would say our preachers-how they boasted themselves and their high authority; and beheld the pomp of our prelates, and how busy they were, as they yet are, to set

* B. iv., part ii.. 4282. This petition, signed 'Humfrye Munmouthe, draper of London,' gives the facts of his life as just stated. He complains in it that, through his imprisonment, he had only sold 2.2 cloths 'since Christmas, 1527.' The 'Articles ministered' against Munmouth were twenty-four. Article 3 declared that he has 'given exhibition to persons occupied in translating the Bible, as Sir William IIochin, alias Tyndalle, and Friar Roye, an apostate Observant'; Article 4, that he 'helped Tyndalle and Roye to go to Almagne to study Luther's sect." -B. iv., part ii., $4 \geq 60$.

† See Tyndale's Works, P.s., i., p. 90 ; ii., $90-98$. 
perce and unity in the world (though it be not possible for them that walk in rlarkness to continue long in peace, for they cannot but either stumble or dash thenselves at either one thing or another, that shall elean unquiet all together), and saw things whereof I defer to speak at this time; and understood at the last not only that there was no room in my lord of London's palace to translate the New 'Testament, but also that there was no place to do it in all England, as experience doth now openly declare."*

Tet there were those in London, whom Tyndale regarded as brethren in Christ. Dean Hook, referring to Wycliffe, remarks, $\uparrow$ " When the time of his departure came, while there were many who piously and in secret studied the sacred volume he had placed in their hands, yet he left behind him not a religious party, but only a violent political faction, which, in his name, propagated what would now be ealled the prineiples of socialism.' No doubt to mix political with religious aspirations was a mistake, however strong the temptations to such confusion; and after the insurrection and execution (1+17) of Sir .John Oldeastle-the ' $g o o d$ lord Cobham ' - the stream of Lollard history runs, as it were, underground. A terrible record in the statute Book survives to mark pretty nearly the eommencement of this obseurity, and their extinetion as an avowed party. It needs to be the more distinetly stated that Wyeliffe's Biblical version not only taught his countrymen 'the copiousness and energy of our native dialect,' but continued to form a centre of common belief and appeal to a faithful and united remnant, whose character was essentially religious. Not only was his translation to be met with in the feutal eastle, + where Wyeliffe had found strenuous

* Preface to the Five Books of Moses, Tyndale's Works, P.S., i., p. 3966.

+ 'Lives of Archibhops,' new series, i., p. 206.

' $\Lambda$ s for the byble $y^{t}$ the Mastr hatb, I wend the utmost pryse harl not passed v. in'rk (marks). -Fenu's 'Paston Letters,' iv., p. :3or. Sir John Fenu olserves: "The only printed edition of the Bible at the time was "Biblia Lat., Mognnt.," by J. Fust and P. Schoeffer, 146.', which would have cost more.' 'Thus the Bible referred to was Wyeliffe's.

Wreliffe translated the New Testament himself, 1:301); Nicholas de Hereford added the Old 'Testament-- the Apocryphal as well as the ('inonical books: John Purvey, Wycliffe's curate, revised both (1388).see Lechler's 'Wyelifle,' plp. 441-4t5. 
adherents, but detached copies of particular books were treasured by very many persons of a humbler grade, who pinned their faith on Scripture rather than on the Church, and who were scattered throughout England, although chiefly resident in the Metropolis and the neighbouring districts. Wycliffe had not lived and laboured in vain, even without taking into account Huss and Bohemia. There is abundant evidence that there was in England a body of men and women, not inconsiderable even in numbers, constrained to a close freemasonry by common peril, who looked upon one another as brethren, and felt an earnest interest in a common momentous cause. These were ready to welcome with intelligent joy a translation of the inspired writings, not from the Vulgate like Ir ycliffe's, but from the Greek and Hebrew originals; no longer in manuscript, but printed; couched in language not, almost obsolete, which Wycliffe's had become, but plain and fresh. Although the fire of Lollardism, trodden down under the iron heel of power, seemed quite quenched, some embers remained glowing with the old fervour, which only needed a breath from heaven to be again fanned into a flame. The heavenly breath, prayerfully waited for, was soon to come.

The 'Brothers in Christ' of London used to meet at this time, for 'teaching and reading,' at 'one Russell's house, at the gate of Birde's Alley, against St. Stephen's Church, Coleman Street.' Father John Hacker, alias Ebb, is mentioned as one of their chief teachers. Brotherhoods scattered through Essex, Suffolk, Norfolk, and Buckinghamshire were in connection with the central London congregation. These 'Bible Christians' had several distinct portions of Scripture in manuscript, which they highly prized. + Luther had declared the Epistle of St. James to be 'strawy' (struminea) and uninspired, imagining that its doctrinal teaching conflicted with his foundation tenet of 'justification by faith.' The disagreement, which is on the surface, arising merely from variance in the use of terms, only

* Wycliffe's language needed a glossary as much as Chaucer's. Foxe, treating of a book written about 1407 , alludes to "the old speech of that time.' 'Our language,' wrote Wiiliam Caxton (printer, $1476-14 ! 1$ ), ' now used varieth far from that which was used and spoken when I was born.'

-Green's 'History of the English People,' ii., p. 57.

$\dagger$ B. iv., part ii., $4029,403 \%, 4175,4254,4444,454.), 450$. 
veils an essential fundamental agreement in the true doctrine, which it really renders more emphatic. This epistle was a portion of Seripture much eherished by the practical English mind.* Here is a good illustration of the fact that the English Protestants, however highly they valued Luther's "ritings, maintained, nevertheless, an unfettered independence of judgment.

The chief advantages resulting from Tyndale's sojourn for a year and a half in the Metropolis were his association with the London Christian Brotherhood-to members whereof, doubtless, the seeret of his intended achievement was entrusted - and his gaining the patronage of the generous Monmouth. To these must be added the happy circumstance that he now formed a friendship with John Fryth, whenee the most blessed fruits were subsequently to be reaped. Fryth was a Fellow of King's College, Cambridge, and therefore known, without doubt, to Tyndale's brother Martin. The acquaintance, which now ripened into the closest mutual affection, probably commeneed when Tyndale himself was studying at Cambridge. But it was from Tyndale's lips, during his stay in London, that Fryth received 'the seed of the Gospel and sincere godliness.' The new convert proved to his instruetor the brightest solace in a sorely-tried earthly lot; more than Melanethon was to Luther-even what Timothy had been to Paul-his 'own son in the faith.' How the hearts of the two bosom friends warmed as they discussed the paramount importance of having Holy Seripture 'turned into the vulgar speech,' that the poorest might 'rear and see the simple, plain Word of God'! How they fired one another's zeal as they concerted together the best ways and means for bringing to pass such a blessed consummation!

The hopes presenterl by a review of the state of the Anglican hierarehy and the king and his Court at this period seemed cold and cheerless beyond parallel. Wolsey was ruler of Chureh and state, and he was Cardinal Legate. Henry was 'defender of the faith,' and thus Rome's pledged champion.

* For instance: "Ahont fonr years ago, was contracted to Joan, danghter of one Dyer of Fynchenfeld, now dead, who taught him the first chapter of James.'- B. iv., part ii, 48,i). 
To translate Seripture had been expressly prohibited in a Convoeation held at Oxford (1+0s) under Archbishop Arundel. Even to read Wyeliffe's version had been pronounced heresy. Against heresy the bishops were fortitied by terrible statutes. At this period England seemed a very stronghold of the Papacy-indeed, its firmest fortress, bristling with arms, its ramparts manned by thousands and ten thousands of zealots welded together by community of ereed, and in very many eases by the strong tie of worldly interest also. Potent indeerl and widely extended were the inducements to uphold the established thraldom of superstition by every available means. Above all, it was imperative to keep in the fast bondage of ancient tongues that most successtul and dreaded of all emancipators, the Word of God.

It was impossible that Tyndale could execute the work to which his heart was given and his life consecrated in any spot in England. Whither should he go to perform, with adequate security from interruption and molestation, a duty bound upon him by God and his own eonscience? Antwerp was under the government of Margaret of Savoy, the daughter of Maximilian, and aunt of Charles $\mathrm{V}$., a rigid Romanist. But there were eighty fice cities, dotted over a large extent of territory from the Baltic to Cologne upon the Rhine, which were united in the famous Hanseatic League. The commerce of this great League was as active and prosperous along the northern coast as that of the Lombards in the south; and in Bruges the Lombard and the Hanseatic merchant met, and the industrious Fleming traded with both. Hamburg was a principal city in this great mercantile confederacy, the power of which was too formidable to be invaded or tampered with, even by erowned heads. The citizens of Hamburg, like those of several other free cities, had recently abolished the Mass and renounced the Pope, and had invited from Rostock Kempe, formerly a Francisean, to become their preacher. There were, moreover, in Hamburg those who were in close business association with the generous Monmouth, and in whom personally he could repose eonfidence. The balance of advantages, therefore, decided Tyndale's choice in favour of Hamburg, which free eity was also a ground of vantage in 
another particular scarcely to be omitted from the calculation. But of his more remote destination hereafter. It is true there were also numerous . Jews in Hamburg then, as now; but this can hardly have been a factor in attracting 'Tyndale thither, for it was on the translation of the Greek New Testament that his thoughts were concentrated for the time being. Nor did Hamburg possess at this period, or for long afterwards, as 1). Maitland has shown, * the privilege of a printing-press. Hamburg itself, however, was only to be a spot of temporary safe sojourn, a place of transit to a yet more advantageous retreat for study.

Tyndale, therefore, embarks on board a merchant-vessel bound for Hamburg, in company with a friend who was to act as his amanuensis-not Roye, who joined him later. He leaves with Monmouth his 'Sermons' and two copies of his version of the 'Enchiridion,' which perished irretrievably in the sad troubles which afterwards befell the noble-minded merchant, greatly through his patronage of Tyndale. He has received from Monmouth the gift of ten pounds. Another equal sum, 'got of some other men,' he cntrusts to his patron's care, to be forwarded to him when he may require it. Commended to God with devout supplication, he bids farewell to the brotherhood and to Fryth, buoyant with hope that his momentous life-work shall yet be accomplished. But scarcely can he have realized, as the white clift's are receding from his sight, that he is never to set foot on the land of his birth again.

* If the 'Laudes beate Marie Virginis' had been printed there (?) 1491, no other book was printed there for forty-five years afterwards. Maitland's Essays, pp. 371-375. 


\section{IV.-THE ENGLISH NEW TESTAMENT PRINTING.}

Fon nearly a year and a half our information respecting Tyndale is comprised in a few prineipal faets. He reaches Hamburg about .June, 152t. His immediate neeessities are supplied by the ten pounds whieh he has brought with him. After the lapse of nearly a year, probably in April, 15.5, he is again in Hamburg, and sends for his other ten pounds to his patron Monmouth; and a present of a 'little treatise' accompanies his request. It has been eonjectured that ' Matthew and Mark,' which, as has been clearly authenticated, Tyndale published before his collective New Testament, are intended under this vague expression, a 'little treatise;' but the word's of Mommouth's own petition in his troubles effectually preclude sueh a supposition.* He safely receives the second ten pounds by 'one Hans Collenbek, a merehant of the Stilyarde.' In the autumn of 152.5 he is in Cologne.

The question which naturally arises then is, Where was Tyndale during the space of nearly a year, which intervened between his landing at Hamburg and iLonmouth's communieation with him by Collenbek? Did he spend the interval at Hamburg? or elsewhere? And if so, where?

There is a consensus of statement on the part of friend and foe, Cochlieus, Nore and I.eet agreeing with Foxe-indeed,

* Monmouth's Petition (May 19. 1528) states that he had also 'a little treatise,'which Tyndale sent him when he sent for his money. All these books, he continues, 'except the New Testament,'- the whole volume subsequently published-'have been openly in my house for more than two years, etc.' Monmouth would never have suffered 'Matthew and Mark' to 'lie openly in his house.'

$\dagger$ IIore, in his controversial writings, passim. Cochleus, to James $\mathrm{V}$. of Scotland, June, 1533: 'Eight years ago two English Apostates, who had learned German at Wittenberg, translated Luther's Testament into English, etc.'-B. vi., 608. Lee, to Henry, from Bordeaux, December "2, 
all contemporary writers attest the same fact-that Tyndale passed the interval of assidnous study at Wittenberg itself. Such unvarying testimony is entitled to eredit on its own aceount; and it is further corroborated by the probabilities of circumstance and of character.

Hamburg is situated seventy miles from where the Elbe pours its waters into the sen; Wittenberg stands much higher up, upon the very same river. It is possible, and proballe, that in directing his course to Hamburg, in preference to any other continental port, the facility of mimpeded aceess by waterway to the famous university from the bustling free mart of commerce, where he would disembark, was present to Tyndale's mind, and helped to determine his choice. Passage by boat from Hamburg to Wittenberg, if the length of distance be exeepted, would be as easy, or easier, than the passage by boat, which we know that he subsequently accomplished on the Rhine, from Cologne to Worms. In an age when roats were for the most part in extremely bad condition, a river offered frequently the readiest and best highway through a comtry, or even through a eity. Thus in London the national river, then the 'silvery' stream which a poet of the next century took for his example, as well as for his 'theme,'* was, in the sixteenth century, the great metropolitan highway, to the neglect of streets foul, or even blocked, with filth of all sorts. Moreover, in Germany, in the summer of 15.5, when the long-seething diseontent of the peasantry was bursting into flame, the dissensions of the agrieultural population rendered journeying by land perilous in no ordinary degree.

That in sailing to Hamburg, Wittenberg should have been Tyndale's real destination, is also in exact harmony with one of the marked traits of his character. The earnest

150-infter a lanent over the spread of Lutheranism in France: "In Englinman, at Luther's instigution, has translated the New 'T'estament into English, and will bring printed copies into England in a few days.'-3. iv., part i., $180 ; \%$.

* o coult I flow like thee, and wake thy stream Iy great example, as it is my theme!

Though deep, yet clear ; though gentle, ret not dull; strong, withont rage ; without o'erflowing, full.'

-Sir John Denham's 'Cooper's Hill.' 
student, who had been fascinated by Erasmus, would naturally be attracted to the far greater theologian, who had alrearly bestowed on (iermany the very boon which he himself was longing to bestow on England, and to a university the very foeus of religious enlightenment for that age.

True, no mention of Tyndale by name oecurs in Luther's correspondence. But in the early months of 1525 Luther was involved in an absorbing controversy with Carlstarl; and, beyond such an irksome tax on his attention, it must be palpable that it was of the first moment for the attainment of suecess, that the scheme to send across the sea, into the midst of the English people, Christ's Testament in their own native tongue should be kept a profound secret. That Luther was well aware of the endeavours making to plant the light of evangelization in the very heart of England is matter of eertainty. In this way only is it possible to explain his second letter to Henry VIII., the mild and deferential tone of which was so unprecedented that this portentous novelty might alone have sufticed to awaken keen suspicion. Henry replied in Latin, and published (December, 1526) both letters in Latin, and afterwards an English version, to which he added a special preface in English. And here appears the express statement that Luther "fell in device with one or two lewd persons born in this our realm for the translating of the New Testament into English, as well with many corruptions of that holy text, as certain prefaces, and other pestilent glosses in the margins, for the advancement and setting forth of his abominable heresies, intending to abuse the good minds and devotion that our dearly-beloved people bear toward the Holy Scriptures,' ete.

It may, then, be concluded, with some approach to certainty, that it is Wittenberg that Tyndale sits down in peace and quiet, with his amanuensis at his side, to eomplete his wellpondered translation. The Greek Testament of Erasmus, with its clear Latin version, had been published 1.516; a second edition had followed 1519; and in 1522 a third. It was this third edition which Tyndale employed. He hears the great Reformer preach; he converses with Melancthon, Bugenhagen and Jonas; his knowledge and use of German are growing 
day by day, and he eonsults Luther's Testament as he proceeds in his work. But his version is made directly from the Greek original itself, and is the result of his own independent toil and judgment, the auxiliary light which other sourees furnished not being despised.

The three collateral aids of which Tyndale availed himself were the Vulgate, Luther's 'Testament, and Erasmus' original Latin version. Of these three, Erasmus was the most helpful. Still, differenees appear, which are alike numerous and important. As regards Luther's version, 'he availed himself fully, to adopt Westeott's words, " of Luther's notes for his own glosses ;' but with the text he dealt 'as one who passed a scholar's judgment upon every fragment of the work, unbiased by any predecessor.' And his influence on all subsequent translations into English of Holy Scripture has been paramount. In Westeott's words, 'he tixed the type according to which the later labourers worked. His influence decided that our Bible should be popular, and not literary; speaking in a simple dialect; and that so by its simplicity it should be endowed with permanence.' Tet did he 'not lower his translation to a vulgar dialect;' as his adversaries feigned, 'but lifted up the common language to the simplicity of his own idiom.' And thus, although subsequently he completed only about half of the Old Testament in aldition to the New, the standard which he established has consistently been maintained throughout; his spirit is everywhere, and gives unity to the whole.

It was currently asserted that Luther himself was at the bottom of the enterprise, or at least intimately associated with it. But this su<picion is overthrown by Tyndale's own flat denial. When Sir Thomas More aceused him, on the evidenee of those taken and convicted here of heresy, of being ' confederate with Luther,' he answered, 'That is not truth.' Luther was not a 'confederate,' although doubtless well aequainted with the undertaking, and sineerely and fervently solicitous for its success.

Tyndale's first amanuensis he describest as 'a faithful com-

* See Westcott's 'English Bible,' pp. 142-152, 164, 165.

+ See the Preface of 'William Tyndale, otherwise called Hitchins,' to the 'Wicked Mammon.' Tyndale's Works, P.S., i., pp. 37-4t. 
panion, which now hath taken another voyage upon him, to preach Christ where, I suppose, he was never yet preached.' His next amanmensis was William Roye, about whose family we know little more than that his mother lived in Westminster. A man of talent, Roye was versed in various languages, but was uncongenial to Tyndale in personal character. 'As long as he had no money,' observes Tyndale, 'somewhat I could rule him; but as soon as he had gotten money he became like himself again.' Glad enough was Tyndale in due time, to use his own words, 'to bid him farewell for our two lives, and, as men say, a day longer.' At last industry, steadily pursued, was crowned with the merited reward. Less than a year's persistent study at Wittenberg was added to previous toil, and the translation was ready for the press.

The Gospels of Matthew and Mark had been already printed: where or by whom is uncertain: but probably at Wittenberg. Of the first fruits of Tyndale's skill as a translator, no separate copy, not even so much as a fragment, has survived. But the fact that Matthew and Mark by themselves preceded the collected English Testament is evidenced by trustworthy proofs. $\dagger$

The entire English Testament has now to be printed. Tyndale, accordingly, having first gone to Hamburg, and received from Monmouth's agent the ten pounds which he had sent for, proceeds in the summer of 15.5, accompanied by Roye, to Cologne. Here he enters into an arrangement with Peter Quentel and Arnold Byrckman, who also had warehouses and a shop in London, to print a quarto edition of the English Testament, with a prologue and marginal notes. At first it

* B. iv., part iii., 5462 .

+ 'Abowght ii yeres agon he companyed with Sir Richard Foxe, Curate of Bumstede, and showed him all his bookys that he bad, that is to say, the New Testamente in Englishe, the Gospel of Mutthrw and Wark in Englishe; . . . certain of Powle's Epistles in Englishe, after the old translation ; the iiii Evangelists in Englishe,' etc.

The distinction of the 'Old 'Translation' (Wycliffe's) fixes the 'Goxpel of 'Hathew and Mark' as of the New (Tyndale's).

'Tyndale and Roye, heretics and apostates, as proved by their' familiarity with Luther and his disciples, and by their commentaries and annotations in Matthew and Mark in the first print; also by their Preface (Prologue) in the second print.'-B. iv., part ii, 39160 . Anderson:Annals, i., p. 153 ; Arber, p. 47 ; Strype, etc. 
was intended to have 6,000 copies printed; but, subsequently, the proposed number was reduced one half.

For some time everything promised well, and good progress was made. Then, all at once, the enterprise was thwarted, and appeared doomed to total failure.

There happened to be lodging with George Laver, canon, a no less rabid foe to truth than John Cochlieus (so his name Dobneck was Latinized), driven from his deanery of the (hurch of the Blessed Virgin at Frankfort, by the insurrection of the peasantry, first to Mentz, and thence to Cologne.* Four years before Cochleus had dogged Luther's steps at Worms. He is as busy, as eager for notoriety, as prying and inquisitive as ever. By a strange coincidence, Cochleus was himself in treaty with (quentel for the publication of some writings of Rupert, Abbot of Deutz-situate just across the river, and connected with Cologne by a bridge of boats. Rupert, in the twelfth century-like the ecstatical Abbess Hildegard $\dagger$ (born 109s), of St. Rupert's, near Bingen, on whom Bernard bestowed praise, and like Joachim, the Cistereian Abbot of Curacio, whor Dante and common fame pronomeed inspired +-had been visited by rays of Divine light in the shade of the cloister. Like Abelard, and like Berengar, Rupert was unable to accept the monstrous dogma of transubstantiation. At least, aceording to Robertson, his 'conformity with the modern Roman doctrine' can only be vindicated by a 'subtle explanation.'s Now that the Reformation was in its early dawn, Rupert's writings were in much request. The purpose of Cochlixus in publishing such writings was to pervert their evangelical sense and tendency. $\|$

* 'Cochlæi Aeta et Seripta' (154!), folio, p. 115, under 15:5 A.D. - Cochlsei Scopa in Araneas Richardi Morysini Angli' (Mareh, 1538).

† Robertson's 'Christian Chureh,' iii., p. 65.

+ 'Il Calarrese abate Gioacehino,

Di spirito profetico dotato.'

$$
\text { 'Paradiso,' xii. }
$$

Joachim died 1:2.2. His prophetieal interpretations are considered by Elliott, 'Horæ Apocilypticæ,' iv., pp. 384-42.2.

s Robertson's 'Christian Chureh.' iii., p. 260.

Rupert's Commentary on Nt. Matthew, 'Of the Glory and IIononr of the Son of Man'-obtained from Liege, where Rupert had been a monk of St. Lawrenee, was printed 1526. A woodeut of St. Matthew, by Arnold 
One day he overheard the printers boasting that all England would soon be Lutheran. A mystery must underlie such a vannt, which he will use all his wits to solve. Accordingly he decoys some of the workmen to his lodgings, plies them with wine, and extorts the secret that the Testament in English, ' a translation,' say the workmen, 'of Luther's German 'Testament,' is passing through their press. Advance has been made as far as the tenth sheet, or $K$, in the quarto edition. What a discovery! The result, too, of apparent accident: Cochlieus, mastering his feelings, feigns supreme admiration. But he at once communicates his discovery to Herman Rincke, formerly ambassador to England, and high in influence at Cologne. Rincke immediately despatches an agent to the printing-office, and ascertains that the information of Cochlaus is only too true. He then procures a mandate from the senate in prohibition of the work.

Meanwhile Tyndale has received information of what has occurred. There is no time to be lost. He and Roye hasten to the printing-house, and bear away the 27,000 quarto sheets already printed. These they pack expeditiously in a boat, and, without dallying, ascend the Rhine with their rescued cargo. Nor do their efforts flag until they and the treasured sheets are under safe guardianship at Worms-a city well disposed to the Gospel, for the seed sown in Luther's trial was already yielding the earnest of a future richer harvest.

Bitter was the disappointment; nevertheless, it was overruled by Providence to ultimate good. Instead of the quarto edition, begun at Cologne, an octavo edition, with only an epistle to the reader at the end, was now printed at Worms. The printer was Peter Schaeffer,* himself happily a hearty Lutheran. He was the son of Schaeffer, of Mentz, assistant to Gutenberg and Faust, who had helped them to perfect the art of printing.

of Worms, a Cologne artist, did service in Tyndale's Testament, and in a mutilated form in Rupert's Commentary. - Francis Fry.

* Fry has proved this by comparing the unique copy of Tyndale's octavo Testament at Bristol with other books from Schaeffer's press, in type, paper, water-marks, etc. Schaeffer's German Bible of 1529 has the same woodeut of St. Paul as Tyndale's Testament. See Francis Fry's 'First New Testament,' Introduction, p. 8, ete. 
This octavo edition was more accurate than the quarto, and presented the pure text of Seripture without the encumhrance of a eommentary - a superiority appreciated in more modern times, although not recognised by Tyndale himself. In the epistle at the end his harassing disappointment finds some faint expression: "Noreover, even very necessity and combratunce (God is record) above strength, which I will not rehearse, lest we should seem to boast ourselves, eaused that many things are lacking, which necessarily are required. Count it as a thing not having his full shape, but, as it were, born before his time, even as a thing begun rather than tinished.'

The quarto edition was completed next.* Matthew and Mark with annotations had been printed separately before. There were, thus, now many whole volumes, or portions, of the Word of Lite, concealed at various places on the Continent, ready for shipment in due season to England. Those whom the Anglican hierarehy had denouneed and forced into exile stood like angels of mercy on the opposite shore, holding out in their hands the Book of God, their gift, won by toil and peril, to their benighted countrymen.

The lading and the sailing of the merehant vessel, which brought the first instalment of the sacred treasure to our shores, deep as was the hopeful anxiety of the good merchants concerned in the transaction, have been shrouded in a dense veil of secreey, rendered necessary at the time by continued danger from numerous enemies, open and covert. It is easy, however, to imagine the scene. Men, hearty in the enterprise, full of zeal and courage, and not without ingenuity, such as Richard Harman and George Constantyne, have stowed the volumes in casks and eovered the surface with Hax. The sailors generally know not that they have aught on board leyond their usual freight. There is the ordinary bustle among the crew, the customary medley of nautical sounds. Ien of faith who are in the secret are praying much, earnestly and believingly; but nothing to awaken the sus-

* The Prologue to the quarto edition was reproduced, almost in the original form, in Tyndale's 'Pathway into the lloly Scripture.'-Works, P.s., i., pp. $7 \cdot 28$. 
picion of the bystanders and lookers-on transpires. $A$ narrow crescent of moon glimmers, the tide is at the full, and the anchor is weighed. The morning reveals the vessel speeding her way prosperously on the mid sea. In such stealthy-wise was there transported across the sea, and up the Thames, into the very heart of old England, the volume of her enfranchisement and of her greatness, "by the "whole vats" full,' as Sir Thomas More complained.

Here it may be interesting and useful to append a brief account of the various editions of Tyndale's Testament and its revisions-published during the Reformer's lifetime. So venomous was the persecution, so strict the search, so effective the methods of destruction, that very few copies remain extant, and of the first edition only one short fragment. The several editions were the following:

I. (1) Of the first edition, the quarto, a short fragment was found attached to a tract of (Ecolampadius, by IIr. Rodd, a bookseller, of Great Newport Street, which now is in the Grenville collection of the British Museum, visible to the public under a glass case. This unique copy only goes to sheet H, Matthew xxii.

(2) Of the second edition, the octavo, printed at Worms by Schaeffer, one copy, perfect, with illuminated capitals, woodcuts, and paragraph-marks, was bequeathed by Dr. Gifford to the Baptist Museum in Bristol, and is there kept in an iron safe. This book was picked up by one of Lord Oxford's collectors (John MIurray), on whom twenty pounds a year for life was settled in recognition of its value, besides an immediate gift of ten guineas. Lord Oxford's library was purchased by Mr. Osborne, of Gray's Inn, and this unique book ("the phcenix' of the whole collection) was sold to Mr. Ames for fifteen shillings. At the sale in 1760 of Mr. Ames' books it was purchased by John White, who sold it in 1776 to I)r. Gifford for twenty guineas. The only other surviving copy (but imperfect) is in the library of St. Panl's Cathedral.

(3) A third edicion was printed in 1.526 at Antwerp by Christopher Endhoven, with Luther's prologue to the Epistle to the Romans, expanded in the translation. 
( $t$ ) A fourth edition appeared in 1.527 at Antwerp, from the press of Hans van Roemundt, the 'John Raimund' of Foxe.

(.5) Others followed. 'By 1530,' says Westeott, 'swiftly and silently, six editions, of which three were surreptitious, were dispersed.'*

II. What has been called, but improperly, the second revised translation was by Joye, and emanated from the press of Endhoven's widlow in August, 15:34, at Antwerp. Tyndale complained that .Joye, when he findeth the word ' resurrection,' changeth it into 'the life after this' or 'very life.' Tyndale charged Joye with not using 'the office of an honest man, seeing he knew that I was in correcting it myself.'

III. The true second revision, 'diligently corrected and compared with the Greek by William Tyndale,' appeared in November, 1534, from the press of Martin Lempereur, at Antwerp. There are two addresses ' to the Christian reader.' The second adverts, as stated above, to Joye's dishonesty. This edition, 'Tyndale's noblest monument,' has marginal glosses, so apt that Westcott remarks, 'Bengel himself is not more terse or pointed.' At the close is a translation of the Epistles from the Old Testament, some of them from the Apocrypha, which are 'read in the church after the use of Salisbury.'

To this edition belongs Anne Boleyn's Testament, bequeathed to the British Museum by the Rev. C. M. Cracherode. On gilded edges, in faded red letters, run simply in Latin, her name and title, 'Anna Regina Anglie.' There is also another copy in the British Museum.

IV. The third revision appeared in 1535. The spelling is peculiar, but inconsistent: 'faether, moether, broether,' etc., solnetimes, however, 'father,' etc. 'The strange orthography, conjectured by the I'.S. editor to be a phonetical adaptation to the Gloncestershire dialect, is really due, in all probability, to a Flemish compositor. Two copies are extant-one in the British Iluseum, the other at Cambridge.

All the editions, genuine and pirated, Anderson reckons as

* The Dutch copy, small 1:mo, without title-page or colophon, in Emmanuel College, Cambridge, usually quoted as Tyndale's, is really Coverdale's, as Dr. Cotton has shown. 
fourteen in number. 'The last, he says, 'a beautiful book in folio,' was printed in London by Bertholet, the King's printer, 1536 , at the very time of 'Tyndale's martyrdom.

The printer was really T. Godfray, a member of Anne Boleyn's party.* Its closing words may serve as a reminder of 'Tyndale and his age: 'God save the king, and all his wellwishers!"

* See Westcott, p. 50 : Anderson's 'Introduction of the English Bible, p. 3. 


\section{V.-THE NEW TESTAMENT EXPECTED.}

INTELLIGENCE from various quarters reached the English court in the closing months of 1525 , and the early spring of 1526 , that a great event, much dreaded by the hierarchy, was imminent. As has been already stated. Cochlieus and Rincke forwarded earnest warnings. So did Eck, Luther's redoubted antagonist. Yet more specific was the information sent by the king's almoner, Edward Lce-afterwards Archbishop of York-from Bordeaux, on his way into Spain. He apprised his sovereign, in the beginning of Jecember, 1525, as a matter of certainty, that an English subject who was with Luther had, at his 'instance,' translated the New Testament into English, and within a 'few days would arrive with the same imprinted in England.' Lee boasted that, 'although this realm of France hath been somewhat tonched with this sect, yet, blessed be God! your realm is yet unblotted.' A shadow, more emphatically heralding approaching events, was the letter of Luther himself, already referred to-a letter indited in full sympathy with Tyndale, who hoped for an English Reformation under royal auspices-and portentous in its tone of conciliatory mildness, which must have reached Henry's hands just as the first consignment of 'Testaments was actually landing.

It pleased God at this crisis to divert the attention of the rulers in Church and State by fears yet nearer, or business more immediately pressing. England was, in that age, one of the least healthy countries of Europe. Contemporary writers complain of the faulty construction of the houses, the windows admitting light, but excluding air; of the chalk floors, laid with filthy rushes, that harboured nastiness of men and $\operatorname{logs}$ and offal; of the salt diet of the people, as well as the abundance of salt water and marshy swamps; of strects grimy 
with mud, and yet worse abominations.* Thus the plagne was a frequent visitant. In the reign of Henry VII. a new disease, distinguished as the 'English sweat (sudor Anglicus),' described as 'a malign vapour,' flying to the heart, and 'seizing the vital spirits,' spread wide ravages, proving too often suddenly fatal. But the winter of 15.2.26 was sickly, far beyond the average. 'In this winter,' writes Holinshed, 'was great death in London, so that the term was adjourned; and the king kept his Christmas at Eltham, with a small number, and therefore it was called the "still Christmas." , The principal ecclesiastics, moreover, had their hands alrearly quite full with business of pressing interest. Tunstal was in Spain. Wolsey was immersed in politics. He was initiating a change in England's foreign relations: leaguing with France against Spain, England's old ally; and pacifying Scotland. Thus warning upon warning poured in to little purpose.

The Gospellers, on their part, were more exactly informed of the near approach of what may be truly called the great event of the period, and more alive to its real import. Yet at a juncture when, if ever, calmness and discretion were imperatively demanded, the Cambridge Protestants, elate with the promised advent of the Book, did all that fatuity could do to endanger the success of the cause which they had at heart. Robert Barnes, not so firm as bold, was the ringleader at ( ambridge in ostentatious indiscretion.

Nicholas West, Bishop of Ely, had been a listener, in the university church, to a sermon preached by Latimer on the high-priesthood of Christ. Taking the Saviour as the model, Latimer delineated, with all the vigour and clearness of Colet, the character and functions of a true priest, especially a bishop. West sent for Latimer, and thanked him for his excellent sermon. 'If you will do one thing at my request,' continued the bishop, 'I will kneel down and kiss your feet. for the good admonition that I have received of your sermon'

Latimer inquired his lordship's pleasure. 'Narry! that you will preach me in this place one sermon against Martin Luther and his doctrine.'

* So Erasmus wrote to Francis, Wolsey's then physician. See Lord Verulam's 'Life and Reign of Henry VII.', and also B. iv., part ii., $2439,4391,4542,4710$. 
Latimer professed ignorance of luther's doctrine, inasmuch as there was a prohibition against reading his writings. "Sure I am,' he added, 'that I have preached before you this day no man's doctrine, but only the doctrine of God out of the Scriptures. If Luther do none otherwise than I have done, there needeth no confutation of his doctrine. Otherwise, when I understand that he doth teach against the Scripture, I will be ready with all my heart to confound his doctrine as much as lieth in me.'

" W'ell, well, Mr. Latimer, I pereeive that you somewhat smell of the pan : you will repent this gear one day.'

This eonversation the bishop followed up by preaching himself in Barnwell Abbey in opposition to Latimer's teaching; and not only this, but, going a good step farther, he inhibited Latimer from preaching in his diocese. And now Barnes came forward; and since the Augustine monastery was exempt from episcopal jurisdiction, opened its pulpit for the inculeation of the truths of Scripture.

('hristmas Eve, 15.5), was long remembered at Cambridge. Latimer preached in the Augustine monastery, Barnes in St. Edward's Church. The latter selected his text from the Epistle for the day, 'Rejoice in the Lord alway,' and delivered a discourse which was in substance Luther's l'ostil; but, with characteristic imprudence, he afterwards diverged to personal topies, and in his remarks glanced at bishops, who, 'like Judas, held the bag,' and, 'like Balaam, rode on asses.' The horns of their mitres he likened to the horns of Ahab's false prophets; their pastoral staff served to knock the sheep on the head. He ridiculed in particular Wolsey's extravagant pomp: his pillars, crosses, cushions, gold shoes and red gloves-'bloorly gloves, to keep him warm amidst his cercmonies.'

Such a discourse at such a time was as a spark which falls into a magazine of explosives. Complaints were forwarded to London, and at length Barnes was summoned before the eardinal; and Wednesday, Februiry 7, 1526, presented himself before him in his gallery at Westminster. He was next arraigned before the tribunal commissioned to deal with heretics. He refused, however to make any confession. 
Then he was sent to the Fleet. Coverdale and other friends were denied access to him. Solitary confinement would scem to have produced the intended effect, for shortly afterwards he was induced to read a paper in acknowledgment of error, and professed his readiness to submit to whatever penance might be imposed upon him.

A search for heretical books, decreed in 152:3, the execution of which had been delayed, was now put in force. And to add emphasis to the resolution, unanimously arreed to by the prelates, to deal with hereties unsparingly, a great fire was kindled Sunday, February 11, 1526, at St. Paul's, 'before the rode of Northen (the crucitix at the north door).' Wolsey himself sat 'enthronized' in his purple on a scaffold erected on the top of the stairs, and together with him there sat six-and-thirty abbots, priors and bishops, his chaplains being in attendance in gowns of damask and silk. Fisher preached the sermon. Then Barnes and some fellow-heretics, described as Easterlings (inhabitants of the Eastern parts of Germany), or men of the Stillyard (a house of German merchants), with faggots at their backs, knelt down and begged pardon, and, finally, were walked round the flaming pile, into which they threw their faggots. Basketfuls of heretical publications were then hurled into the flames. By such a mimic scene Wolsey trusted to inspire terror, and to deter from heresy, by picturing the doom of hereties in the future world.

The sequel of the Cambridge tronbles, not at all creditable to the Gospellers, whose irresolute conduct at this period. and for some time afterwards, greatly dishonoured and retarded their cause, may be best given here. Bilney and Arthur appeared Wednesday, October 27, 1527, at nine o'clock a.m., for examination in the chapter-house at Westminster before the cardinal and many other bishops. Bilney was recognised as having been examined on a previous occasion. He justitied his violation of his oath to preach no more by the poor quibble that the oath had not been administered to him 'judicially.' Examined afterwards before 'Tunstal, it appears that 'the first framer of Cambridge in the knowledge of ('hrist' evinced signs of greater hardihood, and thrice refused to recant. But eventually, over-persuaded by friends, he abjured, listened 
bareheaded, submissively to a declamation against heresy from the pulpit, bore his faggot, and was sent to prison.

George Joye, Fellow of Peter House, had been also cited to appear at Westminster at the same time: and he has himself related-in a sort of postseript to a little book which he afterwards published, in reply to the charges of 'the Prior of Newnham Abbey besides Bedford,' made to the Bishop of Lineoln against him-what treatment he received. On the Saturday following he at length found his way into 'the chamber of presence.' 'There,' he relates, 'no man knew me, nor I them. There was a great fire in the chamber, the weather was cold, and I saw now and then a bishop eome out; but I durst not stand near the tire for fear of burning. There were in all about a dozen bishops, whose solemn and lordly looks pleased me not.' After a time. Joye was informed, he says, that "the eardinal sent not for me.' He was directed to present himself at six o'elock next morning before the Bishop of Lineoln, to whom his suffragan bishop, at the instigation of the prior, had accused him. He did so, but the bishop was not at leisure; ' all the bishops took their barges to wait upon the cardinal that morning to (ireenwich to the king.' The observations and manners of the episcopal ofticials were the reverse of friendly towards Joye; who, in the end, was glad enough to escape by unlinown ways, unharmed by the thieves and robbers who infested the roads, and to reach the sea-eoast, and thus pass to the Continent.

Latimer was treated with appreciative gentleness. He proved to be better versed in Dums and the School-men than Capon or Marshall, the eardinal's ehaplains. The details of what passed in his examination before Wolsey were derived, no doubt, by lialph Norice, Cranmer's secretary, from Latimer's own lips.

Wolsey turns to his ehaplains: "What mean you, my masters, to bring such a man before me into examination? 1 had thought that he had been some light-headed fellow, that never studied such kind of doetrine as the sehool-doctors are. I pray thee, Latimer, tell me the eause, why the Bishop of Ely and other doth dislike thy preachings; tell me the truth, and I will bear with thee upon amendment.'

Latimer, in reply, stated the offence which he had given 
to the bishop by his sermon, 'wherein I deseribed,' said he, 'the office of a bishop as uprightly as I might,' so that he could 'never after abide me; but hath not only forbidden me to preach in his diocese, but also hath found the means to inhibit me from preaching in the university.'

At the cardinal's request, Latimer reviewed the topies of his discourse. 'Did you not preach any other doctrine than you have rehearsed?' inquired Wolsey. 'No, surely,' Latimer' replied.

The eardinal consulted with his chaplains, and after considering whether any other objections could be alleged against the culprit, and, finding none, gave Latimer his own speeial authority to preach. "If the Bishop of Ely cannot abide such doctrine as you have now rehearsed,' said the cardinal, nothing loth to have an opportunity of publicly snubbing his episcopal brother, 'you shall have my lieense, and shall preach it unto his beard, let him say what he will.'

Latimer returned to Cambridge, and after small delay enjoyed the satisfaction of reciting from the pulpit the license, which he had received from the cardinal-legate himself. 'The date of his deliverance from his foes by Wolsey's favour eannot be fixed with any certainty; but the conversation above repeated, which exhilits Wolsey's eharacter elearly, if under a somewhat novel light, took place probably some months after the first consignment of New Testaments had been landed, and had already been partly circulated. 


\section{VI.-ENGLAND'S WELCONE TO HER NEW TESTAMENT.}

Is England loving hearts, eager eyes, and ready hands were awaiting the look, which had been now despatched across the sea. It marks yet more clearly the comnection of the English Reformation with the German, that not only was it at Wittenberg that Tyndale's version was completed, but that Lutheran immigrants were among the first to welcome the Testament to English shores, and take active part in its circulation. Especially is this recorded of the colony of Flemish clothiers settled at Goudhurst and Cranbrooke, in Kent; for at that period the southern and eastern parts of England were the seats of manufacture. Edward III. had allured industrious Flemings into England, and thus laid the foundation of our woollen manufacture. Of course jealousy was rife against those who were regarded by the less persevering natives as intruders. The English monopolists were even dissatisfied that wool was allowed to be exported, since by working it at home, it was alleged, 'the poer pepyll might be fed.' The demand for wool was great, the price high; so that much arable land was put down to grass; ${ }^{*}$ a change similar to that which we have experienced in our own day, although from a very different canse. Inlike the closing years of our nineteenth eentury, rents of land rose exorbitantly with the inereased demand for wool, and house property+ was fetching double the rent it did eighty years before. I pwards of fifteen

* The 'Utopia' attributes partly to this the alarming increase of thieves. See Iibdin's 'Ttopia,' Introduction, p. 181. Burnet's translation, p. 20, and B. i., Preface, p. Ixxvi.

Longland wrote to Wolsey of 'villages, hamlets, mauor places in ruin and decay, the people gone, the ploughs laid down, etc.-B. iv., part ii., 4796. Palgrave laid it to Wolsey's charge, that 'of the 42,000 villages, there be $15,(100)$ removed to dwell in good towns, ete.-B. iv., part iii., 5750 . The art of statisties was in its infancy.

† B. จ., 1788. 
thousand Flemings were computed to be in London; and the total number throughout the country was reckoned at twenty or thirty thousand.* A large proportion of these were Lutherans; 'heretic' and 'weaver,' as appears by the documents of the time, being almost convertible terms. We owe much to the laborious Flemings, whose religious enlightenment helped to diffuse the principles of a purer Christianity, as their plodding industry founded our manufactures.

It was of this Flemish Lutheran element, added to the old Wycliffite remnant, and the accretions continually making by the spread of light and knowledge, that the organized Christian brotherhood, already mentioned, and to be found chiefly, yet not exclusively, $\uparrow$ in and around the metropolis consisted. In the recorded examinations of heretics, such a designation as 'one of the brotherhood,' or ' a known man,' frequently recurs. As soon as the English Testament was safe on English soil, it was on this Christian brotherhood that its distribution and circulation devolved. The 'brethren' had been long accustomed, as has been already stated, to circulate by stealth detached copies of Wycliffe's version; to hide the manuscript behind the wainscot, or under a movable board in the flooring; to read it together in the stillness of the night with barred doors; or in the solitude of thick woods by day. They were principally men of the lower ranksweavers, tailors, cobblers, fletchers (butchers), carpenters, sailors, trade-apprentices, poor clergy. In the dusk of evening, along some unfrequented alley of London or lane in its suburbs, might be descried a member of this earnest but timid fraternity, plodding with his half-concealed bundle of books, until at length he halts at some safe door. It says much for the energy, sagacity and sense of honour which characterized this humble band, that for nearly two years they baffled all the efforts of the hierarchy to detect or stay them. At last a clue fell into Tunstal's hands. Then some of the suspected were summoned before the tribunals, and forced to confess.

* See Du Bellay's statement, B. iv., part ii., 5016, and MIendoza's, B. iv., part iii., 5255 .

$\dagger$ Norfolk was informed that at Mendlesham, in Suffolk, 'unlawful assemblies' of Christian brothers-109, 60,50,30, or 20 persons-used to be held.-B. v., 186. 
The episeopal registers furnish some names, and some suggestive facts.

Interspersed with the humbler members of the fraternity were men of higher station. Such was symon Fyshe, a gentleman of Gray's Inn, 'one of a tall stature,' author of the well-known 'Beggars' Petition:' to which More, 'Proctor of Purgatory,' as Tyndale called him, replied in the 'Supplieation of Souls.' Fyshe was active and earnest in the eirculation of Testaments.* Robert Necton, whose brother was, 15:30, Sheriff' of Norwich, was another member of the brotherhood of good social rank, who, 'himself, and a man of his also,' as More complained, 'sold many such books of heresy, both in London and in the shires.'

Necton's confession is instructive.

'He bought at sundry places of Mr. Fyshe, dwelling by the White Friars, in London, many of the New Testaments in English, that is to say, now five and now ten; and sometimes more, and sometimes less, to the number of twenty or thirty, in the great volume. The which New Testaments the said Mr. Fyshe had of one Harmond, an Englishman, being beyond sea' (Richard Harman, a native of (ranbrooke, in Kent), ete. ... 'About a year and a half agone he fell in acquaintance with Vicar Constantine here in London, which showed this respondent, first that the said Mr. Fyshe had New Testaments to sell, and caused this respondent to buy some of the said New Testaments of Mr. Fyshe. And the said Mr. Fyshe at the desire and instance of Yicar Constantine brought the said New Testaments home to this respondent's house. And before that Vicar Constantine caused this respondent to buy some of the said New Testaments, he had none, nor no other books, except the chapters of Matthew.

'And, moreover, this respondent saith that about the same time he sold five of the said New Testaments to Nir William

* Fyshe, a native of Kent and graduate of Oxford, acted (hristmas, 1526, in a play at Gray's Inn, a part offensive to Wolsey. In the persecution of $15,0 \mathrm{x}$ he must have been on the continent. Early in 1:20? lic publisbed his 'supplication for the Beggars.' No spiritual man, said this librl, ought to be Lord Chancellor. Edmund Modelis, or Mody, placed the book in Henry's hand, who locked it up in bis desk for private perusal. Fyshe died in $1.5 \% 10$ in London. 
Furboshore, singing-man, in Stowmarket, in Suffolk, for seven or eight groats apiece (2s. $4 d$., or 2 s. $8 d$.).

'Also he saith that about Christmas last he sold one New Testament to a priest. . . . Also Vicar Constantine at divers times had of this respondent about fifteen or sixteen of the New Testaments of the biggest (the quarto). ... Also he sold Sir Richard Bayfell two New 'Testaments, unbound, about Christmas last, for which he paid 3s. 4d.'

The avidity with which the English Testament was welcomed is convincingly proved by the high price paid for it, money being then about twelve times more valuable than it is at present. Some of the humbler clergy not only purchased the book, but even allowed their own parsonages to be a depository for the dangerous merchandise. And not only were parish priests thus implicated; but anong the monasteries scattered over the country, here a monk or friar groping for heaven's daylight, and there a pious lady abbess, turned the unsuspected convent itself into a receptacle for the dreaded book, and disposed of copies to persons whose fidelity and discretion were beyond suspicion.**

The New Testament, in a tongue 'understanded of the people,' was first on English shores, 1526, about the end of March or the beginning of April. It was probably in the August or September of the same year that a conclave of bishops was summoned by Wolsey to deliberate upon the measures which it might be expedient to adopt under the alarming circumstances which had then become patent to all. Roye 'presents an entertaining version of what passed at the episcopal meeting,' and his 'rhymes' have, at least, served to transmit to us the rumours that were afloat among the 'brethren' at the time.

The question is proposed, What must be done, in face of the terrible fact, that the book, the words whereof are a death-knell to the pretensions of the hierarchy, has actually got into the hands of the common people? Standish, the

* B. iv., part ii., 4029, 4030, 4175, 4218, 4243, 4254, 4545, 4694, 4850. See Arber, pp. 46,47 .

Essex was honeycombed with brethren; Colchester and Bumpstead are mentioned especially.

The price of the English 'Testament varied from 9d. to $4 \mathrm{~s}$. 
Cordelier, Bishop of St. Asaph (or De Sancto Asino, as Erasmus was wont to style him), comes forward to enter his accusation against the book. The Cardinal, like Pilate, avers that he finds 'no fault therein,' but demands the opinion of the rest. Then Tunstal, 'Bishop Caiaphas,' pronounces categorically for condemnation and burning. The sentence propounded by Tunstal is put to the vote and agreed to unanimously :

\footnotetext{
'The Cardinal then incontinent

Against the Gospel gave judgment,

Saying to brenne he deserved;

Wherto all the bishoppes cryed,

Answering it cannot be denyed,

He is worthy so to be served.'
}

Luther had burned the Pope's Bull, the prelates will burn the English Testament. Paul's Cross, as a central, conspicuous, and noted spot, is chosen for the grand bonfire. The Bishop of London now comes forward himself as the preacher; and denouncing the book destined to the flames, proclaims that he has detected 'above three thousand errors' in the 'ill-made' translation.

This, it must be carefully noted, is the line of opposition which the prelatical party adopt. Not daring to find fault with the words of Christ Himself, there is no censure which they are not prepared to fling at Tyndale's plain and expressive version. Ridley, Tunstal's ehaplain (uncle to the illustrious reformer), whom ('avendish, W'olsey's biographer, has described as 'a very small person in stature, but surely a great and an excellent clerk in divinity, characterized the work as 'this common and vulgar translation of the New Testament into English, rlone by Mr. William Hichins.' 'My lord'-Tunstal was reputed an able Greek scholar-' hath profoundly examined it;' so Ridley wrote to Golde, Warham's chaplain. Then one of the real objections to the version is allowed to peep out. "By this translation shall we lose all those Christian words'-what Tyndale called their ' juggling terms '- 'penance, eharity, eonfession, grace, priest, church.' Tongues of flame, illumining 'Tunstal's condemnation, thus proclaim the verdict of the Anglican hierarehy to all Christendom. Rome, of course, exults, and, in response, 
sends her grateful approval and warm congratulations to England and her king. 'No holocaust could have becn more acceptable to God.' This first authoritative burning of the English Testament took place probably in September, 1526, for there is a letter from Campeggio to Wolsey, dated November 2, 1526, which speaks of 'the praise and glory which the king had won' by the recent conflagration.*

A century or so earlier such an authoritative auto-da-fémight have answered its intended purpose. But it was now too late in the career of progress, with the printing-press continually at work, men's hearts stirred to their very depths, reason and observation debating questions of faith and practice, for the mere denunciation of authority, intensified by a public ceremonial, to have any deterrent effect upon reflective minds; and such were daily growing in enlightenment as well as in numbers. On the contrary, the public burning of the Testament furthered the cause, not of oppression, but of inquiry. It exhibited on a conspicuous stage prelatical hatred to truth, and led the multitude to compare the habitual lives of the bishops with the precepts of the book which they had rejoiced to reduce to ashes. Fisher, in one of his sermons denouncing Martin Luther, had remarked that Luther, by burning the Pope's Bull, had given a manifest sign how gladly he would have burned the Pope's holiness also 'if he had had him.' Tyndale retorted, 'Rochester and his holy brethren have burned Christ's Testament; an evident sign, verily, that they would have burned Christ Hinself also if they had had Him.' +

The demonstration at Paul's C'ross was only the flaming

* C Cum summâ ejus laude et gloriâ auditum est, majestatem suam sacrum Bibliæ codicem, qui . . . vernaculo sermone depravatus et ad ejus regnum dilatus fuerat, justissime comburi fecisse.' See Arber, p. 4! ; Westcott's 'English Bible,' p. 36, note.

$\dagger$ Works, P.S., i., p. 2.:1. Tyndale harped exultingly on this proof of episcopal fury: 'Some one will ask, peradventure, why I take the labour' to make this work (the Wirlitd Jammon), inasmuch as they will burn it, seeing they burnt the Gospel? I answer, in burning the New Testament, they did none other thing than I looked for ; no more shall they do if they burn me also ; if it be God's will, it shall be so.'-I., lpp. $43,44$.

Again : 'Still Saturn (Tunstal), that so seldom speaketh, but walketh up and down all day, musing and imagining mischief, a ducking hypocrite, made to dissemble. He burnt the New Testament, calling it "doctrinam peregrinam" (strange learning)!'-II., p. 337. 
preface to solemn injunctions from Wolsey, Tunstal, and Warham against concealing or reading English versions of the Scriptures. Voysey, of Exeter, was commissioned to search for New Testaments.* And early in 1527 the king himself issued a paternal warning to his people: "We, of our especial tender zeal towards you, have determined the said untrue translations to be brenned (burnt), with further sharp correction and punishment against the keepers and readers of the same, reckoning of your wisdoms very sure that ye will well and thankfully perceive our tender and loving mind towards you therein, and ye will never be so greedy upon any sweet wine, be the grape never so pleasant, that ye will desire to taste it, being well advertised that your enemy before hath poisoned it.'

A bonfire upon a yet larger scale now commended itself to Warham's fancy, and he circulated among the bishops his scheme for raising a sufficiently large sum of money by subscriptions to buy up the whole stock of Testaments, to make them fuel for the flames. This notable device elicited a smile from More ; but the bishops, by word of mouth, by letters, and by actual contributions, warmly seconded the project. Blind old Bishop Nixe, of Norwich, displayed an ardour beyond that of younger prelates. He forwarded to Warham ten marks, observing in an epistle, with his characteristic staunchness: 'This matter and danger hereof, if remedy had not been provided, should not only have touched you, but all the bishops of your province.' In a letter three years later, when Nixe was constrained to admit that the plan had turned out a failure, he yet regretted his lack of 'gretter auctoritic to punyshe.' His quaint language is best set in his old quaint spelling: 'I beseiche your good lordshep that a remedy may be had. For now it may be done well in my diocesse, for the gentilmen and commenty be not greatly infect, but marchants and such that hath ther abyding not ferre from the sea. . . . There is a collage in Cambridge, called Gunwell (Gonville) haule, of the foundation of a Bp. of Norwich. There is no clerk that hath commen ought (out) lately of that collage, but saverith of the frying-pan, tho he speke never so holely.' The

* The mandate bears date November 3 1526. See B. iv., part ii., 2607. 
sum of $\mathfrak{E} 669 \mathrm{~s}$. $4 \mathrm{~d}$.--little short of a thousand pounds, according to the present value of money-was collected and expended in execution of Warham's scheme.*

Wolsey, himself (August, 1528) smarting from the sting of Roye's satire, requested Rincke to seize the persons of Roye and Hutchins (Tyndale), and to buy up their writings. But they had 'not been seen at Frankfort since Easter, and were gone no one knew whither.' Rincke, however, purchased of John Schott, the Strasburg printer, what books of theirs he had on hand, and congratulated the cardinal on this fortunate bargain, since otherwise the books would have been 'wrapped in paper cover, packed in ten bundles covered with flax,' and transmitted by sea to England. The unflagging zeal of the prelates in their self-interested work of destroying English New Testaments is fully evidenced by results. Of the octavo edition only one complete copy is extant; one other imperfect. Of Tyndale's quarto edition there only remains a venerable mutilated fragment.

Piles of books, denounced as heretical, were thrown to the flames; yet the multiplication of such books outstripped their destruction, and, naturally enough, was even quickened by it. Tunstal struck upon a new design. He licensed More (March 7th, 152s) to 'read and keep heretical publications,' and exhorted him, as one able to 'play the Demosthenes' alike in English and Latin, to use his 'spare hours' to expose, 'even to rude and simple people, the crafty malice of the heretics,' whereby he would ' get himself an immortal name and eternal glory in heaven.' 'Thus was More brought into direct collision with Tyndale. Of their controversy some account hereafter.

* R. (Nixe) congratulated Warham (June 14, 1527) that he had 'lately got into his hands all the books of the New Testament translated into English, and printed beyond the sea, as well those with the glosses joined unto them as th'other without the glosses, for $£ 669 \mathrm{~s}$. $4 \mathrm{~d}$. Thinks he has done a gracious and a blessed deed,' etc.-'Hoxne in Suffolk,' B. iv., part ii., 3176.

Gardiner amused Pope Clement with 'a merry tale of the Bishop of Norwich, his good heart, and how, being about fourscore year old, he would have a chamber devised near the ground, without any stairs, to lie in twenty years bence, when he knew he should be somewhat feeble. Ibid., 4120. 
But a clue has now been obtained to the proceedings of the principal agents in the New Testament traffic, and it is not long before Tunstal's bloodhounds are upon the track. The virulent persecution of $152 \mathrm{~s}$ exhibits Tunstal in chief prominence. Not that he was more cruel than his episcopal colleagues; he was, in fact, less sanguinary than his successor Stokesley, and his letter to Wolsey on the New Testament traffic is a sample of moderation and calmness in contrast to the tone of Longland's letters on the same subject. But he was drawn to the van in the ranks of persecution by the position of his diocese. London was the centre of the religious movement. The victims of Papistical vengeance fill the Lollards' Tower at St. Paul's, and crowd the other prisons of the London diocese. Of one of those inculpated-Gough the booksellerTunstal wrote to Wolsey: "I committed him to the Fleet because all my prisons be full of other persons ont of the furthest parts of my diocese.'*

In this fiery ordeal which the English reformers were calied upon to pass through, the most memorable incident is the Oxford Salt-fish Cellar catastrophe. Lamentable in the judgment of those then alive, this sad tragedy may be said to occupy a place in the annals of the English Reformation -if the disparity in the number of the sufferers be excluded from view-similar to that which the Calcutta Black Hole tragedy occupies in the records of British India.

A principal source of our information is to be found in those 'Puritan writers,' on whose statements J)r. Maitland has attempted to throw some discredit. He does not discuss, he says, the point whether they had a right to deceive their persecutors; but asks whether, as they tell us without compunction, that they said what was false to others, they may not 'be doing the same to us.' $\nmid$ But the point which he does not discuss is surely in reality vital. The frank avowal of deceit 'without compunction' shows that they, at least, persuaded themselves that they were fully justified; and can

* See B. iv., part ii., $4175,4218,4 \div 42,4254,4260$.

In modern times the name of Lollards' Tower has becn misapplicd to a tower of Lambeth Palace.-Maitland's 'Essays, p. 24, note.

† Maitland's 'Essays,' pp. 11, 12. 
hardly be distorted, so as to impeach their veracity, when the question of life, furnishing an overpowering motive for deception, was no longer paramount. Collateral information added to internal evidence leaves no doubt of the truth of the main facts recorded by them. Some of their graphic details suggest incontestably a very low condition of morality in that age. And this was the result, among other causes, of the benighted religious teaching of the times, to the influence of which they themselves had been exposed in their previous training.

A narrow lane in Cheapside, nearly opposite to Bow Church, still bears the name of Honey Lane. Three centuries and a half ago the little church of Allhallows stood near this lane. The church perished in the Great Fire, and Honey Lane Market now occupies the site of the ancient edifice and its parsonage. Dr. Robert (or Thomas) Forman (or Farman), whose sermons were very attractive to the Gospellers, was Rector of Allhallows.* John Goodale, and also Geoftrey Usher, 'of St. Antonyes,' are both spoken of as his servants in documents of the period, and are described as 'infectious persons.' Thomas Garrat, or Garrard, of Magdalen College, Oxford, an enterprising agent in the sale of Testaments, was his curate. Garrat was known as a Gospeller, and had been abjured, together with Bilney, so recently as the previous November, by the cardinal for speaking against the Pope's authority. John Gough, a bookseller, of Fleet Street, was likewise implicated in the New Testament trattic. 'A Dutchman from Antwerp, named Theodoryke,' is mentioned as having ' brought many books.' +

* Forman died October 31, 1528. It is interesting to notice Anne Boleyn's sympathy with him, as shown by her letter to Wolsey, B. iv., part iii., Appendix, 197. Her later zeal in the same cause appears in her letter to Crumwell in behalf of 'the bearer, Richard Herman (Harman), merchant and citizen of Antwerp in Brabant,' who 'was in the time of the late Lord Chancellor expelled from his freedom and fellowship of and in the English house there, for nothing else (as be affirmeth) but only for that he still, like a good Christian man, did both with his goods and policy, to his great hurt and binderance in this world, help to the setting forth of the New Testament in English,' etc. This later letter bears date, 'Given under our signet, at my lord's manor of Greenwich, the xiii day of May' (1535).

+ B. iv., part ii., 396:, 4004, 4017, 4030, 4173, 4175 ; Holinshed, iv., p. 898. 
Garrat arrived Christmas Eve, 1527, in Oxford againhaving been there the previous Easter-and brought with him a fresh store of books, New Testaments amongst them. Just before this visit he had sent 'two heavy fardels' of books to Oxford. All these the Cambridge colony weleomed and prepared to distribute. But, meanwhile, the clandestine tratfic had been detected. Forman's rectory and other suspeeted places were searched, and prohibited books were found buried under the ground. Forman himself professed that he had studied Luther's writings in order to know his opinions, and be the more ready to defend the Church. He was forbidden by Tunstal (Thursday, March 19) to perform mass or preach. Directions for the apprehension of Garrat were forth with despatched to Oxford. Cole, of Magdalen, happened to be that year proctor, and he apprised Garrat of his danger. Upon this friendly warning Garrat fled with precipitation into 1)orsetshire, to a brother of Dalaber-who, however, was ' a rank Papist'-intending to offer to serve him in the capacity of curate.

Only a few days have intervened from Garrat's Hight, when Malaber, as he is perusing Lambert on St. Luke, is interrupted by a knock, and again a more impatient knoek, at the door of his room in Gloucester (now Worcester) College-for to this college Dalaber had just removed from St. Alban's Hall, leaving, however, his books in his old room in St. Alban's, 'in a very secret place to keep them safe.' The visitor, impatient for entranee, proves to be Garrat himself, 'looking like a mazed man!' 'I am undone!' he exclaims in the hearing of the servant. His story is soon told. He had relinquished the journey into 1)orsetshire, and had returned; had slept at Radley's (a singing man's) house, had been taken by the Proetors, and delivered over (Saturday, February 12) to Dr. Cottisford, Master of Lineoln, and Commissary of the University. While all were at evensong he had slipped back with his finger the bar of the loek and effeeted his eseape. Garrat's hood and gown are now thrown aside; he puts on a sleeve-coat of Dalaber's 'fine eloth in grain,' his priest's cap he retains. The two friends kneel down and ask the Divine protection, then Garrat starts for Wales. Dalaber eloses his 
door, and taking in his luands the New 'Testament of Erasmus, reads over 'with many a deep sigh and salt tear' the tenth chapter of Matthew.

After this Dalaber hastens to carry tidings to the 'brethren.' It is arranged that all shall meet at 1)iot's room, of Corpus Christi, at five o'clock. Dalaber then passes on to St. Frideswide's. Evensong is begun. The dean and canons, in their gray amices, are chanting the Magnificat. Dalaber pauses and listens. Taverner, one of the brethren, is playing the organ.

Presently Dr. Cottisford, 'bare-headed and pale as ashes,' hurries through the choir door, makes straight to the dean's stall, and talks with him in a whisper. They leave the choir together. Dr. London, Warden of New College (afterwards a visitor of the monasteries under Crumwell*), meets them " pufting, blustering and blowing like a greedy lion seeking his prey.' At length, about the middle of compline, Clerk comes from the choir, and has the intelligence of Garrat's capture and subsequent escape communicated to him. 'Nay God,' he exclaims, "vouchsafe to us the wisdom of the serpent, and the harmlessness of the dove. We shall shortly have need of both.'

The next morning, Sunday, Dalaber, having passed the night in St. Alban's with Fitzjames, rises at five o'clock, and repairs to Gloucester College. He finds the gates unopened, and has to wait until after six o'clock before they are opened, much later than was the custom. Hastening to his room, he finds to his consternation that the lock of his door has been picked, and that his bed-straw has been thrust through with bills and swords. His pupil from the adjoining room comes in, and instructs him to go at once to the prior.

The prior, Anthony Dunstan, a monk of Westminster, requires Dalaber to put down in writing all that he may know about Garrat. The quick eye of the prior perceives on the undergraduate's forefinger a ring of silver, "very well doublegilted looking as of gold.' 'Let me see that ring, young man.' Turning it round, and scanning the letters marked on it-A and $\mathrm{D}-$ ' It is my ring!' exclaims the prior, 'A for Anthony,

* On Dr. London, see Gasquet's 'Henry VIII. and the English Monasteries,'i., pp. 464 , etc. 
and D for Dunstan.' ' Would,' thought Dalaber, 'I might be as well delivered of your company, as I am sure to be of that ring !'

Dalaber turns to his writing; but before he has put down three words the beadle presents himself to eonduct him to Lineoln College Chapel. There Cottisford, Higdon, Dean of Frideswide, and London, of New College-the last 'the rankest Papistical Pharisee of them all,'-are standing at the altar and awaiting his appearance. He is made to swear on a mass-book that he will answer their interrogations truthfully: but ' in my heart,' he acknowledges, 'I nothing so meant.' With their utmost efforts the three heads of houses fail to extort anything from him detrimental to Garrat. Battled of their purpose, they at length remove Dalaber upstairs into a large unfurnished apartment, where they lock his feet fast in the stocks.

In an age of superstition, when even Warham procured a license to practise neeromancy, it will not be judged extraordinary that the authorities in their perplexity now resorted to such help as astrology could afford them. The Commissary, being 'in extreme pensiveness,' caused 'a figure to be made by one expert in astronomy.' The information thus elicited was that Garrat had 'fled in a tawny coat south-eastward, and is in the middle of London.' Astrology proved at fault. Not long afterwards, on the last day of February, Garrat was apprehended at Bedminster, having in vain tried to aceomplish his escape by any passage over the water within fifteen miles of Bristol. The strictest wateh had been maintained.

The joyful intelligence was at once conveyed by Longland, the Oxford Chancellor, to his patron, Wolsey. "The wicked man is taken,' and is now 'in Ilchester prison.' He adds, 'Garrott, Clerke and Freer have done much mischief; for the love of God let them be handled thereafter. I fear they have infected many other parts of England.' Garrat was carefully examinerl; and after the examination, Longland, in another letter, described him to Wolsey as 'a very subtyl, erafty, soleyne, and an untrewe man, as will appear by a comparison of his answers with those of the scholars.'

His plan frustrated, his hopes blighted, the Cardinal now empties the tiereeness of his dire wrath upon the hereties 
whom, like so many vipers, he has nourished in his own bosom. They are found to have in their keeping three hundred and fifty-four heretical publications. Higdon proceeds to communicate the measures which he has adopted to Wolsey. $\mathrm{He}$ has kept ' in ward Mr. Clerke, Mr. Sumnar, Mr. Betts and Sir Frithe, being canons primi ordinis, Sir Baylye, a canon secundi ordinis, and Sir Thos. Lawney, a priest of the Chapel,' etc. Tanner and Radley, as being unlearned, had not been imprisoned. The dean adds, 'Easter is near, and many of them are excommunicated.' He expresses, therefore, a hope that the Cardinal will 'absolve them, that they may take their rights in Holy Church.' But all Wolsey's bowels of compassion had been turned to gall. In vain did even Longland incline to mercy; and himself suffering from the gout, wrote to the Cardinal that it would be 'a gracious deed' to license those scholars who have been 'detect for having of evil books,' those that are priests to celebrate, and the others to 'receyve their Maker after reconciliation,' at this feast of Easter. But Wolsey still remained inexorable. The outcome was, that the ringleaders in heresy, 'the most towardly young men in Oxford,' thrust into an underground pit, 'a prison within a deep cave,' according to Foxe, where 'their salt fish was laid,' pined away under the terrible ordeal, pent in amid foul air, from March till August. The year 1.528 was marked by pestilence throughout England; and 'the reigning sickness,' seizing upon frames debilitated by confinement and bad diet, vouchsafed to four of the sufferers the happy release of death. One of these was Clerk himself. When dying, he requested that he might be allowed to receive the Eucharist, but was refused.* He solaced his departing spirit with the dictum of Augustine: 'Believe, and thou hast eaten (Crede, et manducasti).' The rest seemed likely to follow their brethren to the grave. The commiseration of the University and the city deepened. At length Warham relented; and at last Wolsey

* Thos. Byrd, priest, to Crumwell, Sept. 1, 1528: 'The reigning sickness troubles my lord Cardinal's College. Mr. Clerke's brother and another scholar died abont three weeks ago; last week Mr. Summer (sic), that was accused; and on Monday last Mr. Clerke. Jesus pardon their sonls! They were buried in Christian sepulture, but the Sacrament was denied them by the Dean. The other three, who are still alive, remain in their old custody.'-B. iv., part ii., 4690. See ibid., 3962, 3968, 3999, 4004, 4017, 4073, 4125, 4150 . 
himself. The survivors crawled out of their prison, resembling corpses drawn from the tomb. All the kind attentions that compassion could prompt were bestowed on the victims of the Cardinal's disappointment and wrath, who, with one exception, by slow degrees recovered.

Some of those implicated in the evangelizing efforts of the Cambridge colony at Oxford afterwards rose to distinction and dignity in the Reformed Church. Fryth after a time escaped across the sea to Tyndale. Garrat outlived his humiliations, became in course of time chaplain to Hugh Latimer, and at length (15:37) was himself appointed Rector of Allhallows; and in 1540, faith and constancy at last matured, was honoured, in fellowship with Barnes, with the crown of martyrdom. Dalaber lived until 1562; and under Elizabeth wrote that interesting narrative, sparkling with incidental graphic touches, which, embellished a little here and there, perhaps by the lively pen of the martyrologist, has been reproduced at full length by Froude, as bringing us face to face 'in its minute simplicity with that old world.'

What man could do, the hierarchy did to buttress their own authority, and to hold the human mind still inert and powerless in the iron shackles of unreasoning submission. But all their counsels, threats and penal inflictions were a vain striving against God. Providence made even calamity subserve merey. The very vessels that in the pinching straits of scarcity were welcomed with inexpressible joy, laden with wheat and rye for the famine-stricken Londoners, together with the bread that perisheth, discmbarked also a new instalment of the bread that endureth. Notably, too, in 152s, when the persecution was at its fiercest heat, an unexpected antagonist, the sweating sickness, in ghastly array against tyranny, took the part of the down-trodden 'brethren.' By the middle of June, forty thousand persons had been attacked, and two thousand had fallen victims to the scourge in the eity of London, at a time when its population was reckoned at seventy thousand only.* Tunstal withdrew from his palace by London Bridge to the purer air of Charing Cross. The search for Testaments was suspended, and the persecuted had rest.

* See the Report of England, made to the Senate of Venice by Lodovico Falier.-Ven., iv., 694. 


\section{VII.-THE 'WICKED MAMMON' AND THE 'OBEDIENCE.}

ThE English Testament being now in print, and printing its truths in English hearts, the link, which for a time had bound Tyndale and Roye together in uneongenial fellowship, was broken. Tyndale gives pretty elosely the date of their separation. 'After we were departed, he (Roye) went and got him new friends . . . and when he had stored him of money, he got him to Argentine (Strasburg), . . A year after that, and now twelve months before the minting of this worl' (the 'Wieked Mammon'), 'came one Jerome (Barlow) through Worms to Argentine,' etc.* As the 'Wieked Mammon' was published May, 1528, the spring of 1526 is fixed with tolerable exactness as the date of the separation of Tyndale and his seeond amanuensis.

Jerome was another so-called 'Apostate Observant' of Greenwieh, $\uparrow$ and was warned by Tyndale of 'Roye's boldness,' and exhorted to 'walk quietly and with patience, and longsuffering, aecording as we have Christ and His Apostles for an example.' But at Strasburg old influenees resumed their sway. 'William Roye,' narrates Tyndale, 'whose tongue is

* Preface to 'The Wicked Mammon.'

† Jerome Barlow was noted for 'red hair,' as Roye for skill in languages.-B. iv., part iii., 5667. Demaus conjectures Jerome to have been identical with William Barlow, who acknowledged that he had written agaiust the Mass, supposing 'Jerome' to be an assumed monastic name.Demaus' 'Tyudale,' p. 313, note.

There was also John Barlow, or Carolo, Dean of Westbury, described as 'of small stature, with red hair, sober in eating and drinking, ete.,' who knew both Elizabeth Blount, Harry Fitzroy's mother-whom he spoke of as 'eloquent, gracions, and beautiful'-and Anne Boleyn'more beautiful still.'-B. v., 1114.

William Barlow was Bishop of St. Asaph February, 15936 ; was trans. lated the same year to St. David's; and in 1548 to Bath and Wells. On Mary's accession he went abroad. 
able not only to make fools stark mad, but also to deceive the wisest, that is, at the first sight and acquaintance, gat him to him, and set him a work to make rhymes, while he himself translated a dialogue out of Latin into English, in whose prologue he promiseth more, a great deal, than, I fear me, he will ever pay.'

The 'Dialogue' was followed by the celebrated satire on Wolsey, 'The Burying of the Mass,' in English rhyme, beginning :

'Rede me, and be not wrothe,**

the joint work of the two ex-friars. The printer was Schott, of Strasburg.

To personal ridieule and satire Wolsey was morbidly sensitive, and as little pleased with Roye and Jerome as with the opprobrious Skelton - that Jonathan Swift of the reigns of the two last Henrys, unsurpassed in coarse invective, the author of 'Colin Clout;' and, although himself a priest, a satirist of the elergy, and especially of Wolsey. The Cardinal, by his emissaries, sought to get the two ex-friars into his hands, but strove in vain to have them apprehended.

Tyndale, on his part, did not receive the extraordinary composition of the two friars with any degree of approval. He was apprehensive that damage would be inflicted on the cause so near to his heart; and he harshly blamed as unbecoming to the Christian profession the rlymes wherewith they assailed the Colossus of Church and State, whom he himself nevertheless subsequently styled ' a misshapen monster,

* 'The first stanza predicted Wolsey's sudden fall :

'Rede me, and be not wrothe,

For I say nothinge but trothe ;

I will ascend, makrnge my state so hye,

That my pompous honour shall never die.

O Caytyfe! when thou thinkest least of all,

With coufusion thou shait have a fall.'

The satire will be found in the Harleian Miscellanies, B. M.

$\dagger$ John Skelton (1460-1533), a protégé of Margaret, mother of Henry VII., was tutor to Henry VIII. and Poet Laureate, and was much commended by Erasmus. Ile was forty years of age before be took Holy Urders, when he was promoted to be Rector of Diss, in Norfolk.B. iv., part i., 1235. Colet was the preacher, Erasmus the scholar, More the philosopher, and Skelton the poet of the New Learning. 
sprung out of a dunghill.'* 'It becometh not,' he complained, 'the Lord's servant to use railing rhymes, but God's Word, which is the right weapon to slay sin, vice and all iniquity.' Such strictures expose the translator to the just charge of inconsistency, as well as of prejudice. For a writer such as Tyndale to censure railing in another is evidence of the deep self-ignorance even of the best of men. More, in his turn, takes Tyndale himself severely to task on this very same score, and with equal inconsistency. "In his "Obedience," wrote More a little later, ' he raileth at large against all popes, against all kings, against all prelates, against all priests.' But, in fact, it was an age in which men who felt strongly were not required by general opinion or literary taste to put any strict restraint upon the language in which they expressed their feelings. All were railers; More himself sometimes little less gross and virulent in his railing than even Luther himself.

Rhymes were merely the outside form in which the railing was couched, and surely such an outside form was at least quite innocent. Rhyme had no place in classical poetry; but introduced first into Latin ecclesiastical hymns-the Latin tongue abounding in consonances-obtained ere-long a firm footing in modern literature. Rhyme-like iterations of a phrase or a word, so common in all literature-answers a certain demand of the soul. The Provençal poetry exhibits what Hallam calls ' the most intricate disposition of rhymes.' Of our own poets, Chaucer adopted 'rhyme' when its value had become recognised; Spenser employed it; and Shakspere occasionally; Nilton with exquisite freshness in some minor pieces; Pope at length, in his love of point and glitter, carried the art to a high finish of mechanical exactness. How immeasurable the loss, if all that has the adornment of rhyme should be expunged from modern poetry! Or if rhymes, which long preceded blank verse, of which no specimen had quite as yet made its appearance, be taken in a larger seuse, as it oftentimes was, as a synonym for poetry in general, who could have known better than Tyndale, that the 'Vision of Piers Plowman,' in its alliterative Saxon verse, had done knight's service, by teaching the people what high

* Tyndale's Works, P.S., ii., p. 322. 
honour God puts on work, and that to do good is far better than to carry about a pocketful of indulgences. The Allegory of William Langland, without directly impugning the papacy, had prepared the way for Wycliffe's Bible, and thus for Tyndale's Testament. But Tyndale was too prejudiced to judge with common-sense and fairness. It must not, however, be inferred that he favoured the fanatical notions of the Zwickau prophets, in their vituperation of literature and learning. Against such a conclusion the whole tenor of his studious life is a continuous protest. The truth no doubt is, that he beheld his amanuensis himself, whom he disliked as unstable, self-willed, vain, and frivolous, through the thin veil of his rhymes, and transferred to these the mean estimate which he had formed of their composer.

From this time, to keep his reputation unsullied, and prevent any confusion of his own writings with Roye's, ${ }^{*}$ he courted the publicity which he had before shunned, and published the treatise which followed his Testament, and which was an exposition of the doctrines which he drew from the inspired volume, distinctly under his own name.

Having quitted Worms, Tyndale, whose labours, exile though he was from his country, mark with tolerable exactness the progress of Christian life and light in the hearts and minds of his countrymen, is next found in the safe and quiet retreat of Marburg. Here he became more thoronghly familiar with the German tongue, and applied himself with steady industry to his sacred studies. Especially he endeavoured to attain greater proficiency in Hebrew, enjoying in the new university the assistance of learned friends whose religious convictions were in hearty sympathy with his own.

Situate in the beautiful valley of the Lahn, a tributary of the Rhine, Marburg was the capital of the Landgrave of Hesse-Casscl, whose castle crowned an eminence overlooking the city. 'The university, recently inaugurated in the

* But such confusion was not obviated. Rincke wrote to Wolsey Oetober, 1528: "Compelled .John Scott to confess that he had printed in English, ferman, French, and other langwages one thousand hooks of six quires (quaterniones) and one thousand of nine, at the order of Roy and Huckyngh, who were unable to pay for them.-B. iv.. part ii., 4693,4810 . 
metamorphosed Duminican convent, was in the full vigour of its youthful energies. Philip the Magnanimous cherished the more advanced tenets of the French and Swiss Reformers; and the professors of his university reflected the liberal tendencies of their prince. Francis Lambert, of Avignon, was remodelling the church according to his characteristic maxim of thoroughness: 'Whatever is deformed must be reformed.' John Lonicer was there, an adept in Hebrew as well as Greek; John Rulelius, distinguished by his beautiful Latin Bible, just issued from (Quentel's Cologne press; and also Herman von Busche (Buschius), the first nobleman who deigned to become a teacher, a pupil of Reuchlin, and an associate of Hutten and Erasmus in the litere obscurorum virorum, which ridiculed the monks with satire, more telling from its apparent unconsciousness. Buschius was professor of poetry and oratory. He had paid a visit to Tyndale, whilst the translator was still at Worms, and afterwards in familiar talk with Spalatin, the Saxon Elector's secretary, had expatiated on the Englishman's singular proficiency in 'seven languages -Hebrew, Greek, Latin, Italian, Spanish, English, and French.* 'You would fancy,' he said, that 'whichever language he spoke was his mother tongue.'

Here in studious peace Tyndale issued from the press of Hans Luft (May 8, 1528), the parable of the "Wicked Mammon' (or 'Unjust Steward'), a reproduction in the main, although not a servile copy, of Luther's teaching on his central doctrine of justificution by fuith. Tyndale had previously published (1526) anonymously Luther's Prologue to the Epistle to the Romens, not, however, compressed in form, but, like his prologues to other books of Scripture, derived from Luther, Englished and enlarged. Luther's Latin text was here chiefly employed, although the German also was evidently consulted. It is in his prologues that Tyndale shows more particularly how powerful was the influence exerted over

* Spalatin's 'Diary' under Sunday after St. Lawrence's Day, 15:6 (August 10). Schelhorn, 'Amæn. Lit.,' iv., p. 431, ed. 1730. In the P..'. biography of Tyndale 'Dutch (German)' is substituted for 'French,' p. xxx. 'If,' observes Westcott, ' the printed reading French be correct, it is unlikely that Tyndale had spent a long time at Wittenberg with Luther.'-Westcott's 'English Bible,' p. 3\%, ed. 187². 
him by the Saxon Reformer. Yet freedom of judgment was always consistently retained, for the prologue to the Hebreus is even a sustained argument in opposition to Luther; and the prologues to the Epistles of James and Jude declare plainly, in contravention of Luther, that those epistles 'ought of right to be taken for Holy Seripture.' The prologue to 1 Corinthians is altogether an independent work.

The 'Wicked Mammon,' and the prologue to the Romansthe latter was often bound up in one volume with Tyndale's Testament-mark the period during which the influence of the great German over the English Reformer's mind was at its zenith, vigorously independent as Tyndale's mind ever was in its exercise of the generally sound judgment wherewith he was endowed. The resemblance of the 'Wieked Mammon,' in its illustrations and language, as well as its doetrine, to Luther's writings is striking; yet the treatise has the impress of Tyndale's individuality stamped upon it with unmistakable elearness.

'Faith only before all works,' says Tyndale, 'and without all merits but Christ's only, justifieth, and setteth us at peace with God.'

'See, therefore,' he insists quite in Luther's manner, 'that thou have God's promises in thine heart, and that thou believe them without wavering: and when temptation ariseth and the Devil layeth the law and thy deeds against thee, answer him with the promises; and turn to God, and eonfess thyself to Him, and say it is even so, or else how eould He be merciful ? ....

'This is therefore plain, and a sure conclusion not to be doubted of, that there must be first in the heart of man, before he do any good work, a greater and precionser thing than all the good works in the world, to reeoneile him to God, to bring the love and favour of God to him, to make him love God again, to make him righteous and good in the sight of God, to do away his $\sin$, to deliver him and loose him out of that captivity wherein he was conceived and born, in which he could neither love God nor the will of God. . . .

'That precious thing that must be in the heart, ere a man can work any good work, is the Word of God, which in the 
Gospel preacheth, proffereth, and bringeth unto all that repent and believe, the favour of God in Christ.'

Union with Christ Tyndale proclaimed to be the sum and substance of Christianity. 'Christ is thine, and al' His deeds are thy deeds. Christ is in thee, and thou in Him, knit together inseparably. Neither canst thou be damned, except Christ be damned with thee. Neither can Christ be saved, except thou be saved with Him.'

The 'Wicked Mammon'. was the manifesto of the English Reformation in regard to religious doctrine. Its publication preceded by the short interval of five months another characteristic treatise, which (published October 2), advancing from theological doctrine into the domain of practical life, carried the teaching of Scripture into the affairs and relations of the home and of the government and nation, and then wound up with a powerful description of the corruptions and iniquities of 'insatiable Antichrist;' for so 'Tyndale designated the gigintic papal system. This treatise was entitled 'The True Obedience of a Christian Man, and how Christian Rulers ought to Govern' - the largest, most popular, and influential of Tyndale's writings.

Filmer himself, a century and a half later, did not enunciate the duty of passive obedience, pure and simple, with more unswerving distinctness than did Tyndale in this tract. The Reformer went so far as to assert: 'He that judgeth the king judgeth God.' 'Whatsoever is done to us by them (kings), that,' he maintained, 'doth God, whether it be good or bad. If they be evil, why are they evil?' When kings 'turned contrary to the nature of their names and offices, even into lions, bears, foxes, and unclean swine,' all the hideous complications of moral and physical evils that ensued the Reformer regarded as God's vengeance upon us for 'our unnatural and blind unkindness' and 'our rebellious disobedience.' The king was the image of God on earth. This doctrine of Tyndale, that the authority of the king was immediately derived from heaven, was the general belief of that age ; just as two centuries or more previously it had been the general belief that the pope was actually God upon earth.

On this one point Tyndale was quite in unison with 
Henry VIII. and his minister Wolsey, who was extending and deepening on despotie principles, such as the Reformer taught, the foundations of the edifice of our national polity; even as subsequently Crumwell earried the work onward, and put on it what may be ealled the eoping-stone. Suecess in the establishment of real despotism, under the mockery of ancient constitutional forms, was faeilitated by the eharacters of the English monarchs in whose reigns the ehange was wrought. Edward 1V., with whom the new absolutism had its commeneement, and his grandson Henry VIII., under whom it attained its meridian eompletion, were both gifted with considerable ability, and both exerted also the charm of popular manners.

But the prineiples themselves were adapted to the circumstanees and dernands of English society at this partieular stage. Noble blood had been shed like water; haughty and ambitious houses had been humbled or swept away; many onee wealthy were now involved, through the protracted eivil strife, in aceumulated debt. Moreover, in the light of the reeent past, the necessity was apparent of a strong eentral authority, to hold in eheck what aristoeratie turbulence might yet survive, and at the same time to curb the insurrectionary fanaticism of the populace. The elergy had been courted in the eivil eonfliet, and thus their influenee had increased; but with the inerease of immunities, irregularities also of life and discipline had reached a rank growth. The elergy might be relied upon to inculeate reverence for the throne, if the sovereign upheld the church; and apprehensions for their own well-being, amid signs threatening soeial change and even convulsion, naturally disposed them to seek regal protection. But here too, for the correction of gross abuses, and the removal or abatement of seandals, a wise head and firm hand, and oplortunity to use both, were urgently required.

If, however, 'I'yndaie exalted the irresponsible supremaey of the throne above the will and even the criticism of the subject, he humbled it to the dust before the judgment and majesty of Heaven. Monarehs and judges were warned of the strict aceount to be rendered at the bar of the heavenly ling and Judge regarding the manner in which a saered trust had been 
fulfilled. Earthly sovereigns were emphatically reminded that 'the people are God's, not theirs.' Nor could anyone utter a more decisive protest than did Tyndale against the usurpation of temporal jurisdietion by pope, cardinals, bishops, and clergy, to whom 'emperor and kings are nothing nowadays, but even hangmen.' At the same time, the Reformer insisted with great force upon the paramount obligation resting on the clergy to discharge to the full the functions of their proper vocation. 'To preach God's Word,' he proclaimed, ' is too much for half a man.' And then, later on in the treatise, as though in anticipation of impending legislation, 'One king, one law, is God's ordinance in every realm.'

It was the fashion of the day to find fault with Tyndale's ' rash and rude spirit,' his 'homely and simple' style; without which, however, his writings would have altogether missed their mark. But the 'Obedience' proved acceptable even to Henry himself. It is an aneclote often repeated, and perfectly authentic, that Anne Boleyn lent the book to one of her waiting gentlewomen (Mrs. Gainsford), from whom George Zouch, an admirer, playfully plucked it, and then was himself ' ravished' with the perusal. Dr. Sampson, dean of the royal chapel, snatched the heretical volume out of Zouch's hands, and delivered it to Wolsey. Anne, vowing it should be 'the dearest book ever clean or cardinal took away,' desired upon her knees the king's help for her book. It was restored to her, whereupon Anne herself, taking it to Henry, 'besought his Grace most tenderly to read it.' He did so-especially, no doubt, the most striking passages, which Anne had marked with her nail - and then pronounced, with his accustomed energy, his sentence: "This is a book for me and all kings to read.'*

Whilst at Marburg, in one of the brightest days in his sorely tried lot, Tyndale was rejoined by his son in the faith, John Fryth, fresh from the horrors of the Oxford tragedy. Little more than four years had elapsed since the friends had parted in London. What events had been crowded into that brief

* George Wyatt's memoir of Anne differs only in a few particulars from Strype's narrative, which was taken from Foxe's MSS.-Singer's 'Cavendish,' ii., pl. 202-205 Strype's 'Eccles. Mem.,' i., p. 112. 
space! On either side how much to tell, how much to hear! It can thus excite no surprise that in his next publication, 'The Practice of Prelates,' Tyndale evinced an increased asperity towards persecuting opponents.

It was at this period, whilst his best-loved friend, a well-read theologian, was at his side, that Tyndale's doctrine in regard to the mode of Christ's presence in the Eucharist underwent amendment. More attributed this important change to the influence of Barnes. 'Friar Barnes was of \%uinglius' sect, against the Sacrament of the Altar, believing that it is nothing but bare bread. But Tyndale was yet at that time not fully fallen so far in that point; but, though he were bad enough beside, was yet not content with Friar Barnes for the holding of that heresy. But within a while after, as he that is falling is soon put over, the Friar made the fool mad outright, and brought him blindfold down into the deepest dungeon of that devilish heresy, where he sitteth now, fast bounden in the chair of pestilence with the chain of pertinacity.'

But More was certainly mistaken in supposing that there was any large amount of sympathy between Barnes and Tyndale. They were altogether different in character. Barnes was described by Vaughan as ' an English friar of the orter of St. Augustine, who had long been with Luther ;' and so far the description was correct. But subsequently there is authentic evidence that in December, 15:31, Barnes was in London,* 'at the king's great solicitation.' For, unlike Luther and Tyndale, Barnes was in favour of the royal divorce. It is possible, or even probable, that he may some time previously have passed in the stream of refugees continually going and coming to and from Wittenberg, through Marburg, and he may thus have conversed with Tyndale. But there is certainly no account of such conversation, nor of any visit at all of Barnes to Marburg. More's statement that 'Barnes was of Zuinglius' sect, against the Sacrament of the Altar,' there are good reasons for rejecting entirely as incorrect. 'That such a momentous change took place in his views is as little countenanced by his being consulted

* B. v., 593. 'He (Barnes),' wrote Chapuys, 'adopts a secular habit, and is much with the Franciscan, who is one of the chief writers in favour of the king.' 
by Henry as by his remaining, as he did, in high esteem with the Lutherans down to the very date of his martyrdom. It is distinctly related that at a later period Barnes was one of those who accused to Cranmer of heresy John Lambert, the intrepid martyr, because he held simply the spiritual presence. This fact gives a flat denial to More's assertion. Moreover, a letter of 'Tyndale, written after Christmas, 1532, conveyed to Fryth the following signiticant warning: 'Of the presence of Christ's body in the Sacrament meddle as little as you can, that there appear no division among us. Barnes will be hot ugainst you. The Saxons be sore on the affirmative: whether constant or obstinate, I remit it to God.'* But whether, as llore asserts, the opinion of Barnes on the manner of Christ's presence in the Eucharist underwent, a change, or, as other documents and facts indicate, remained just as before, the weight of his influence on Tyndale's mind in the consideration of such a central topic was not likely to be more than quite trivial.

No doubt Tyndale and Fryth examined together the teaching of Scripture on the question then, as indeed now, uppermost in the theological mind, and arrived in concert at that doctrinal conviction which thenceforward they held in common ; without, however, being in any degree acrimonious against those who differed from them, as was made patent in their writings.

An important coincidence must be recognised in the Marburg Conference. The Saxon and Swiss divines met Friday, October 1, 1529, in the landgrave's castle, and for three days disputed the controverted sacramental topic. The landgrave himself and the Marburg professors listened as umpires.

Earlier in the year the spirit of solemn protest against the disloyal deviation of the Church of Rome from the one Christian faith, as transmitted in God's Word, had uttered its clear voice in the Diet of Spires. Under the perils of their situation, the Protestants, besides appealing to the emperor and a free council, had formed a mutually defensive alliance. And to render this Protestant compact effective, Philip the Magnanimous had arranged, not without a good deal of oppo-

$$
\text { * B. vi., } 403 .
$$


sition and difficulty, a sacramental conference in his own town of Marburg. Foreseeing that the animosity of religious dissension would, at no distant date, compel a resort to the arbitrament of sword and lance, he desired to combine all who favoured doctrinal and ecclesiastical reform in the bonds of closer union and brotherhood.

Luther, on the contrary, disdaining recourse to weapons of carnal warfare, contended resolutely for God's sole arbitrament. Throughout the disputation, which was held at Marburg, he entrenched himself, as in an impregnable stronghold, in Christ's own words, 'This is My body,' and repudiated all and every endeavour to define with mathematical precision the mode of the Divine presence. Christ, he maintained, Divine and human, is present in the elements reclly; not, however, through priestly consecration, but by virtue of His own word ; yet 'not as in a place.' Except the saeramental divergency, on all other points agreement was attained. The Swiss and Saxons parted, holding one another to be 'friends,' but not 'brothers.'

Whether 'Tyndale was present at this conference, and thus the representatives of the Reformation in Germany, in Switzer land and in England, all three met at an important crisis in religions progress, must remain matter for question. $\Lambda$ good deal of uncertainty attaches to Tyndale's movements about this juncture. At least, however, he was fully informed of all that passed, and sincerely lamented the injury to the common eause, wherewith intestine strife was surcly pregnant. Without being gifted mentally so richly as Luther or Zuingle, he had more of moderation and prudence than either. Hore, too, of that humility which, fearing perehance to go wrong, is on that very aceount more likely to be led aright. It is certain that he cordially desired union, and that he trusted to attain it through the only safe path of mutual forbearanee. 'I would have the right use preached,' he urged, 'and the presence to be an indifferent thing, till the matter ean be discussed at leisure. 
VIII--MURE, HIS FAMILI AND MANOR-HOL-E.

The sharp struggle in the early years of the English Reformation had drawn into decisive prominence in the very van of the fight two redoubtable champions. These were, on the one side, Tyndale, supported by his henchman Fryth, and on the other Hore, supported by the venerable Fisher, the worthy Tunstal, by the rest of the prelates, 'and by a noisy hive of friars and monks.' The conflict was being fought out in eity and university, in convent and baronial hall, by word of mouth and by treatise, by sermons from the pulpit and arguments at the supper-table. That More came forward at length to do single battle against the exiled tract-writer and translator is a sign that the bishops were by no means easy at the prospects of their cause.

Ilore was, in some respects, the most remarkable Englishman of the age, if exception be made of Wolsey himself, whose attention was distracted by a multiplicity of engrossing political cares. Hore enjoyed an European reputation; his legal studies had enlightened his mind on the true theory of the English Constitution, but had not quenched his theological zeal. A lawyer by profession, he was a Churchman in soul. His able pen had been summoned to the controversy by Tunstal, to do swift and sure execution. Goliath was to smite off the head of the stripling David.

Several centuries have intervened since the noted controversy. But the topics debated were of no ephemeral interest More himself, despite his later reactionary notions in religion, deservedly takes rank with the best of our English worthies; as great a favourite, and as familiar to us to-day, his words as fresh as if he had jested with Mistress Alice, or discussed 
theology and ethics with Margaret Roper, or watched the gambols of the family pets only yesterday. His memory has been enshrined in the national heart, by his moral and domestic excellencies, setting the crown on genius and learning.

A little more than three centuries and a half ago Thomas More was living at Chelsea (or Cheichithe, or Chelseth, as he would spell the name*), 'three small miles from London,' in the manor house which he had built, $†$ with his second wife; surrounded by his three daughters and their luusbands, some grandchildren, and his one and only son John and John's wife. His son, named after his grandfather, had been born (1509) last of all, and was in intellect a melancholy contrast to his father, who it is recorded had half reproved the mother's yearning for male offspring: 'God has given you in answer to your prayers a boy-who will always be a boy.' When only nineteen .John married Anne Cresacre. Margaret Giggs, an adopted orphan girl, and Mr. Gumnel, the preeeptor, were also members of the household of Chelsea Manor.

All his children were by Jane, his first wife. Roper narrates : ' Resorting to the house of one Maister Colt, a gentleman of Essex, who had three daughters of honest conversation and virtuous education, his mind most serving him to the second, for that he thought her the fairest and best favoured, nevertheless, lest it should be a great grief and some shame to the eldest to see her younger sister preferred before her in marriage, he framed his fancy toward Jane, the eldest, and soon afterwards married her.' His first wife More selected with a view to training and moulding her to his own high ideal of what a woman ought to be.

Mistress Alice, his second wife, 'Alouisa Middleton' (her Christian name shortened sometimes to 'Alice,' sometimes to

* Cesol' was a bank of sand and pelbles; whenee also Chelsey, or Selsey, in Sussex.

† More's manor-house- 'a right fair one,' with library, books, gallery, ete.-had gateway aud gardens opening on the Thames. It stood near the chureh (now St. Lukes). There wis another manor-house (royal) at (helsea, a quadrangular building, where afterwards Katharine Parr resided with her last husband. More's manor-house got the name in course of time of Beaufort Honse, and was pulled down in 1740 by Sir Hans Sloane. - See Lyson's 'Envirous,' pp. 70-18:. Faulkner's 'Chelsea' (ed. 1810) has a map of the Chelsea of 1661. 
'Louisa'), was neither young nor beautiful ('nec bella, nec puella), ${ }^{*}$ but was senior to Sir Thomas by some years. She was a widow, and was chosen to be his second wife as a good disciplinarian and a thrifty housekeeper. Her thrift, indeed, she carried so far that her husband would sometimes rally her on her 'saving a candle-end and spoiling a velvet gown.' To please her husband, and gratify his musical taste, Dame Alice learnt to play on the harp, Nore accompanying her on the flute. Margaret, her daughter by her former husband, readily fell into the family ways, proving a pleasant companion to More's three daughters, Margaret, Elizabeth, and Cicely. $†$ The wife is described by Roper as 'a simple ignorant woman, and somewhat worldly, too.' Her temper was not without a dash of acidity ; yet More was never known to 'fume, ${ }_{+}^{+}$but 'loved his old wife as well as if she had been a young maid.' 'Whatsoever that could not be helped, he loved it, as though nothing could have happened more happily.' More was compared by Richard Pace to Democritus, the laughing philosopher, or to a skilful cook, who makes his viands palatable with a sprinkling of vinegar.

His eldest daughter, Margaret, married to William Roper, of Eltham, had the largest share of her father's heart, as was shown later on in the farewell embrace upon the Tower Wharf. She was, in fact, an ornament, only second to Sir Thomas himself, to the bright household, which Erasmus termed ' a little house of the Muses, and another academy of Plato, or rather school or university of Christian religion.' The young Swiss painter of Basle, Hans Holbein, introduced

* 'Viduam duxit,' wrote Erasmus, 'nec bellam admodum nec puellam, sed acrem ac vigilantem matrem familias animi minime mollis, postremo ad rem attentissimam.'

$\dagger$ Giles Heron, married to Cicely when she was twenty-one years old, and William Dauntesey, or Dauncey, married to Bessie, were members for Thetford in the Parliament of 1529.-B. iv., part iii., 6043.

† Thus, when, in his absence with the king, his barns were burnt down, he wrote to his wife from Woodstock, September 13, 1529: 'The loss of so much corn is a pity ; but we must not only be content, but be glad of God's visitation. Perhaps we have more cause to thank Him for our loss than for our winning . . Take all the household to church, and thank God ... I pray you to make some good ensearch, what my poor neighbours have lost, and bid them take no thought therefor; for if I should not leave myself a spoon, there shall no poor neighbour of mine bear no loss by any chance happened in my house.' 
by Erasmus to More, and by More to Henry and his court, delineated the family group, not omitting the fool-Henry Pattenden (or l'atteson). The artistic suecess of Holbein's graceful pencil was much admired by Erasmus, who, in return for such a gift, wrote to Margaret: 'I recognised everyone in it, none more than yourself: methought I saw a soul shining through this most beautiful household, even more beautiful.'* Besides the young Swiss artist, then rising into celebrity, Colet, Linacre, and the renowned scholars of the period, were welcome guests at the manor-house. The king himself sometimes enjoyed the hospitality of his distinguished subject. The time was when More would make merry with the king in his 'traverse,' or, visiting him at the palace, would walk with him upon the 'learls' by night, considering the diversities, courses, motions, and operations of the stars and planets. But More loved his own home, and shone there to the best advantage. On one oceasion More's daughters 'disputed in philosophy before the king's grace.' At another time, the king. ' linlooked-for, came to dimner, and afterwards walked in the fair garden by the space of an hour,' his arm around More's neck. More was coneratulated by his son Roper on his royal master's affection. 'Son Roper,' Sir Thomas replied, 'I may tell thee I have no canse to be proud thereof; for if my head would win the king a castle in France, it should not fail to go.'

The charm of More's amiable domestic nature in the bosom of his own dearly-loved family cannot readily be surpassed. Yet was he striet as well as kind. To each nember of the

* Erasmus thanked Margaret Roper from Friburg, September 6, 1529. The scholar writes: 'I have kissed her (the mother Alice's) picture, as I conld not kiss herself. My best wishes to your brother, John More, and your husband Roper.'-B. iv., part iii., 5.24.

Erasmus had sent his portrait in 1523 from Basle. The More family group was a return gift, and is preserved in the town-hall at Basle.Camphell's 'Lord Chancellors,'ii., p. 75 , note. This picture is a pen-andink sketch.

A copy, twelve feet wide, by about nine high, is at Nostell Priory, the seat of Lord St. Oswald, himself descended from Margaret Roper through a IIenshaw. This eopy has the date 1530, faint, but visible on the right band corner.

What is believed to be the original painting was long at Burford Priory, Oxon, and is known as the Burford picture. It is now at Cokethorpe Park, Witney, the property of Mrs. Katharine strickland. 
household a plot of garden ground was allotted, which it was required should be kept in good cultivation. The family pets, too, were numerous. 'There was not lightly any kind of bird,' says Harpsfield, that Sir Thomas More 'kept not in his house; as he kept also the ape, the fox, the weasel, the ferret, and other beasts that were rare.' An interesting page in the 'Colloquies' of Erasmus narrates with what amused interest the Dutch scholar watched the mancuvres of a great ape, an especial family pet, in protecting his favourite rabbits from the malevolent designs of the weasel.*

* See 'Erasmi Colloquia,' under the heading 'Amicitia' : 'Referam quod olim his oculis vidi in ædibus Thomæ Mori clarissimi apud Anglos viri. Alebat domi simium prægrandem,' ete. 


\section{IX.-MORE'S EARLY AND LATER OPINIONS.}

THE firstfruits of More's pen exhibited a liberal spirit, which seemed even inclined to err in the direction of freedom. In the Utopia-which some translate 'a blissful somewhere,' others 'nowhere'-More presented to the learned world at Commonwealth ideally perfect, a biting satire on the laws and usages of society in England. Plato's 'Republic' had furnished the idea; but Hore has greatly the advantage of the Greek philosopher in imparting to the airy fiction of his own imagination 'a local habitation and a name,' an apparent reality, which even deceived many. The book is a standing proof of the remarkable advance of More's mind beyond, not only his own age, but even in some respects beyond the closing deeade of the nineteenth century. He not only, in his remarks on erime and its punishment, anticipated some of the arguments of the reformers of our criminal code, Romilly, Mackintosh, and others, but he even anticipated the aspirations of the brilliant American sage, Channing, for an edueated and refined working elass.

'The second book of the 'Utopia' was written first, the other being introductory. It was eomposed in Latin about 1515, when More was in his thirty-seventl year,* and was residing at Bucklersbury, his first wife still living. At that period he was wont to have Erasmus as his guest, who had now visited England for the third time, drawn back from Italy and Rome by the joyful hopes enkindled in the disciples of the New Learning by having a youthiul prince of their own way of thinking on the throne.

Under Nore's roof Erasmus composed (1510) his 'Praise of

* Seebohm discovered the exact date of More's birth to be Saturday, February 7,1478 . 
Folly,' or 'Moriae Encomium,' its Latin title being a pun on his host's name and propensities. Jike the 'Colloquies' subsequently published (1522) - those well-known interesting and instructive prose idylls, resembling Jucian's 'Dialogues' in form, but very superior in substance--this little book exerted a powerful influence upon educated minds in favour of religious reform. A little later Erasmus devoted his energies to the most valuable of all his labours, his 'Novum Instrumentum,' for so he called his New Testament in its first erition, which was to inaugurate a better era in religion, as Bacon subsequently his great treatise, which was to revolutionize science-the title reproduced from Aristotle's celebrated logical expositions, applicable to all reasoning. The 'Paraphrases' (1517-1520) in elueidation of Scripture were a further contribution from the painstaking scholar to the cause of enlightenment. The year 1516 is memorable. In its March was published Erasmus' 'Novum Instrumentum, and in its October Hore sent to Louvain the introductory book in completion of the 'Utopia.'

The scene of the conversation in which the whole life of the inhabitants of the island of Ctopia is detailed is well laid. More feigns that, as he passed out of Our Lady's Church at Antwerp, he espied his friend Peter Giles (Petrus Egidius) talking with a certain stranger, well stricken in age, sumburnt in face, with cloak cast negligently about his shoulders, by mien and apparel a sea-faring mau. The stranger proved to be a Portuguese gentleman, by name Raphael Hythloday, who had voyaged and travelled much, and had accompanied Amerigo Vespucci in his voyages to the New World. More invited him to his house. They sate down together in the garden upon a bench covered with turves; ; and the stranger spoke of his marvellous adventures, his being left in America by Tespucci, his wanderings, and tinally, his sojourn for five years in the island of Ctopia. The three retired into the house for dinner, and afterwards returned to their seats on the bench, when Hythloday proceeded to give a full and exact

* 'A wood-cut in the Basle Edition (of the Utopia), probably executed by Holbein, represents them (More, Giles, and Raphael) sitting on a bench in the garden behind the house, under the shade of the trees,' etc. Seelwhm, p. 389. A similar vignette appears in Dibdin's 'Utopia' (Boston, Lincolnshire, 1878), p. 164. 
description of the cities, institutions, and customs of the Itopian commonwealth.

In English society and the laws which regulated it, More beheld a conspiraey of the rich against the poor. Thus he was careful to protect the Utopian commonweal against the tyranny of 'Princess Lady Money,' and that 'Mother of all mischief, Pride.' 'The prinee (Utopus), who had gained the land by conquest, by reason of the dissensions of its inhabitants, was a public benefactor, both by wise laws and by good example. The blissful dwellers in the crescent island were exempt from many of the European vices. Of the trifling subtleties of the logieal disquisitions then in vogue they knew nothing. Property in Utopia was possessed by the community; and, although not Christians, the Utopians were welldisposed towards the religion of Christ, because its founder had instituted a community of goods among His followers. Every tenth year the houses were changed by lot. Nothing within their houses was private. The twenty-four hours of the day were so divided that six were devoted to labour, eight to sleep, and the rest to the 'garnishing of the mind.' Besides aequaintanee with husbandry, everyone was required to aequire some handieraft. Virtue was regarded as a life ordered according to nature. Their meals were begun by reading; and no supper was unenlivened by musie. They ate and drank from glass and earthenware; and used gold to make their chamber-pots, and gyves for their bondmen. l'recious stones were not allowed as ornaments, except for children, which at riper years they would cast away with their other toys. Dicers, hawkers, hunters were held in reprobation. The Utopians could find no pleasure in seeing a poor timid hare chased by a dog. Amongst them every mother suckled her own infant.

As regards religion, they worshipled God (Mythra, l'ersian for the sim) in temples profaned by no images, ranged according to households, all elothed in white, the men on the right side, the women on the left. The peculiar rights of the various sects were performed in private. There was no persecution on account of religion. Their priests were few in number and were married. The priest wore vestments emningly wrought 
with divers feathers of fowls, depicting in their proper setting certain divine mysteries. Their specially sacred seasons were towards the end of each month and year; and before public worship at such times confession was made by the wife to her husband, and by the children to their parents.**

Thus the 'Utopia' is significant as containing a decided protest against some of the most demoralizing practices of the C'hurch of Rome. Its plan also for combining religious toleration with comprehension is very remarkable. It must be confessed, however, that the harmony of the ideal excellence was somewhat marred by a few notes of discord. The Utopian marriage customs were more curious than delicate. $\dagger$ Suicide, if sanctioned by the priests, and by the council, was permissible, and even praiseworthy. But very memorable as a whole was such an achievement of an intellect singularly bold, in constructing a well-ordered social system of human beings, whose unity and pure and useful living were a reproof to English vice and selfishness. The promise, however, proved deceitful in no ordinary degree of the mature harvest to be reaped eventually from a mind of such original genius.

More found himself almost in a new world, when ten years had passed from the time of the publication of the completed 'Utopia.' The guides of his youth and early manhood were gone, or changed. Colet had passed to his rest. His constitution had sunk (October 16, 1519) under the effects of the third attack of the sweating sickness. He left a void which his successor Pace, a court sycophant, could ill fill. The long nave of Old St. Paul's was no longer visited as before by many a Lollard, creeping in and taking his place in the congregation, to listen to a preacher who, although not a Wycliffite, had perused Wycliffe's writings, not without profit. To More this loss of his early guide was great. It shows how entirely More subsequently deserted his old moorings for the dark and deadly waters of Rome's delusions, that he wrote to Erasmus, enjoining him no longer to propagate his former religious opinions, but rather to retract them. Erasmus himself had been alienated more decidedly from Luther by their contro-

* See Dibdin's 'Utopia,' pp. 241, 249, 250, 255, 26:-4, 2-2s, 2\$4, 2!11-3, 308, 346, 352-4, 363, 371.

† Lord Bacon modifies these customs in his 'New Atlantis.' 
versy on free will. Thus More remained alone to choose his own course; and events which supervened in rapid sucession shook into ruins his early New Learning tastes and notions.

Iore's total and almost sudden departure from his early liberal speculations to Romish bigotry and intolerance has been regarded as a puzzling enigma. Certainly it is a melaneholy disappointment. His political views continued much as before. Tyndale, on his part, sincerely desired the amelioration of the condition of the labouring class: but he looked for this resulc to the instrumentality of lingly power, acting in the fear of God. More attributed less to royal authority ; and as a constitutional lawyer, and as an Englishman, disliked heartily the absolutism of Henry, Wolsey, and Crumwell. It is the more surprising that in religion he should have receled to the unsafe ground of a fanatical Romanist, inasmuch as a papist, such as his friend Fisher, he never beeame. Roper states that the king's book against Luther, in completing which he rendered help to Fisher and Lee, as ' a sorter out and placer of the principal matters,' brought him to 'believe that the pope's primacy was by institution of Gind.' 'This statement can plead the authority of More himself.* Yet he declares in the very same letter, in which he remarks on this change of his former opinion regarding the pope's primacy, that he 'never considered the pope above the general council;' and it is noteworthy that, in his subsequent 'Dialogrue, his definition of the Chureh contains no referenee whatever to the pontift-an exclusion which cau hardly have been unintentional. Henry's book may have served to detach him also from some other of his previous New Learning notions. And to this beginning of opinions more in consonance with the Roman system large additions were doubtless made when he took up his pen to prop the king's halting cause against Luther's vehement retort.

Chelsea Manor and the Wittenberg monastery bore a resemblince to one another so far as that both were rematkably halpy homes. 'Their prineipal inmates also, illustrious to all time, resembled one another in the highest moral worth and in large mental eompass. They were skilled in musie and poetry,

* See llore's letter to Crumwell, dated March 5. 1534.-B. vii., ‥\$9. 
in both which, however, Luther was greatly the superior. Nore had not much of Luther's deep aequaintance with patristic literature; Luther was devoid of More's legal attainments. In both a keen sense of humour went with a nature of intense truthfulness. Both shone with unusual brillianey in the domestic circle; both were childlike in their enjoyment of children's interests and amusements. Religion was to both the centre of all else; but in their idea of true religion the difference was great.* 'Faith,' said Luther, ' is a "correlative :" as parent implies child, and teacher seholar, so faith implies Christ; it is thus that faith suves.' Christianity, so pure, divested of ecclesiasticism, was too simple for the author of the 'Utopia' in his more mature days.

Luther knew the shorteomings and inadequacy of the New Learning; for More, on the other hand, the Augustinian theology of Luther had little charm. Indeed, the votaries of the New Learning generally would have been satisfied with merely a moral reformation, for the achievement of which they looked forward ehiefly to improved edueation. Luther, on the other hand, believed in morality as sound only when it was based on the doetrines of God's IWord. From nature and eulture alone he expected very little. His spiritual eonvictions hat been burned deep into his soul in the fierce fires of overpowering conflict. To such stupendous struggles as his, in the agony of prayer against Satan, sin and his own heart, in order to learn God's truth, More's spiritual experience had made but feeble approach. The life-and-death wrestlings which had prostrated

* On some salient points these differences may be stated thus:

Luther held Justification by Faith, a doctrine which. a little later, was accepted by Cardinal Pole, by Contarini, Valdez, and others. More's confused ideas on this subject much resembled the strange amalgam of Divine mercy and human merit which the Conncil of Trent comlounded afterwards. 'Luther and his felowes,' wrote More. ' amonge other theyre damnable heresyes, have one that all our salvacion standeth in faith al ne, and trward our salvacion nothing force of good workes' etc.- Workes (1557)

The Church, with More, was determined by visible marks and lines. The Creed, said Luther, declares, 'I believe in the Holy Catholic Church ;' and Scripture instructs us, that Faith is of 'things unseen'

With Mere the vow of celibacy, strictly kept, was meritorions. With Luther, matrimony was 'the holy estate.' 'I wish to marrv', be stid. ' before I die, that I may answer the inquisition of God: "Where is thy belpmeet? I made thee a help-meet, where is she?"' 
the 'solitary monk' at Erfurth and at Wittenberg lay outside the sphere of More's feelings and convictions, whether in his earlier religious development, when he built his creed on the facts of Christianity rather than on texts of Scripture - like the other men of the New Learning - or in its later phase, when he took up with the myths, trivialities and absurdities of the Roman Church. It was not to discover doctrinal truth, but to overcome temptations to deviation from the path of duty, that More continued in prayer 'full many a restless night with a heavy heart.' IIore's Christianity was thus principally practical.

Moreover, Luther's teaching had apparently contributed to set Germany on flame; and the conflagration threatened to spread to other lands. Against the promulgator, then, of tenets in common judgment so revolutionary, Nore grasped the pen with burning ardour. And it is easy to understand how the wit and orator of lively impulsive temperament threw himself heart and soul into his arguments, and, being theologically superficial, if he failed to convince others, at least effectually convinced himself.

No doubt other motives contributed to further his deliberate alteration of belief and purpose; and the chief of these may be detected with little difficulty. His thorough success as an advocate dated from 'the famous cause of the great ship of the pope arrived at Southampton, which the king claimed for forfeiture.' The cause was heard in the Star Chamber. More was counsel for his holiness, and won the suit.* Before long he reached the settled post of advocate for the pope in all causes; and it was only natural that this confidential relationship, as it grew by degrees more intimate, should exert an increasing influence upon the Romeward tendency of his religious views. His successful advocacy against the crown, instead of offending, induced Henry to press his talents into his own service, without listening to any refusal.

* More was Master of the Requests, knight, and of the Privy Council, 1514. Not long afterwards he removed from Bucklersbury. Between 1514 and 152:3 he was frequently an ambassador in the Low Countries, and in 15:1 Treasurer of the Exchequer; Speaker of the Commons, 1523 ; Chancellor of the Duchy of Lancaster, 1525. The Great Seal Henry delivered to bim ' in his Manor of Plesaunce at East Greenwich' on Monday, October 25,1529 . More resigned the seal May 16, 1532. 
Some would say that, finding he had in his tongue a key to a gold treasure, he thenceforward made his conscience beat time to his eloquence. But such a suspicion would wrong an honest heart which hated covetousness.* He was always sincere, and pleaded for the innocent and indigent without reward. But, when elevated to higher social ground, he, like many others in similar circumstances, began to regard matters under a new light. Questionings and novelties of disquisition, which might not misbecone a barrister in large practice, would little beseem the Chancellor of the Duchy of Lancaster, and still less the Lord Chancellor of England. The spirit of innovation revealed to him its national perils more alarmingly, when he himself had been raised to be one of the most conspicuous figures and buttresses of the state.

Thus, from a combination of motives, he 'went violently back,' in Hallam's words, ' to the extreme of maintaining the whole fabric of superstition.' He upheld and enforced, as of the very essence of Christ's Gospel, the supremacy of Church authority over both scripture and reason; and its concomitant dogmas - the arrogant fiction of sacerdotalism, the delusive system of objective sacramentalism, and even transubstantiation, comparatively recent in origin, yet paraded by Rome in the forefront of her pretensions-an invention so absurd and monstrous in itself, that according to Tillotson, its weight must 'crack the very pillars of St. Peter's.' The doctrines of Scripture, lucidly expounded by Tyndale, he did not comprehend. His professional studies riveted him day by day to authority and precedent, and aggravated his Romeward bias. To his eyes the yawning chasm, which seemed opening wider and wider as the Reformation progressed, threatened to engulf whatever had been held sacred for centuries. Like a traveller exploring an unknown region, starting back, he hurried away in the contrary direction, when his feet appeared to be standing on the edge of a precipice.

As judge, his integrity in all temporal causes was unimpeachable. He once said to his son-in-law, Dancey, "Were it my father, whom I reverence dearly, that stood on one side, and the devil, whom I hate extremely, on the other, his cause

$$
\text { * 'Animus a sordido lucro alienissimus.'-Erasmus. }
$$


being good, the devil of me should have his right.' Filial veneration adds emphasis to such words. "Whensoever he passed throngh Westminster Hall to his place in the Chancery, by the Court of King's Bench, if his father' (whose age was nearly ninety), 'one of the judges thereof', had been seated, or he came, he would go into the same court, and there, reverently kneeling down, in the sight of them all, duly ask his fither's blessing.' Yet notwithstanding his inflexible justice in ordinary eases, his discrimination, where religion was concerned, would sometimes become cloudy. The poor heretie cowering before him might be deceived, if he relied too absolutely on his habitual probity. But the judicial forehead might on a sudden relax, and the springs of compassion be touched, by such answers to interrogations as tickled an unusually quick sense of humour.

He has been charged with fastening heretics to a tree in his garden, called the 'Tree of 'Troth,' and scourging them, and with sending a suspected heretic to the rack. In reply to such accusations we have his own words in self-defence, which serve to acquit him of actual inhumanity, at least with his own hand.* Lord Camplell sums up the case, on More's own evidence, very much to his entire exculpation. "We must come to the conclusion,' he writes, 'that persons accused of heresy were contined in his house, though not treated with cruelty, and that the supposed tortures consisted in flogging one naughty boy, and administering stripes to one

* 'Except in sure keeping. I never else did cause any such thing to be done unto any of the heretics in all my life, except only twain : one was a ehild, and a servant of mme in mine own honse, whom his father, ere he came to me, had nursed up in such matters, and set him to attend George Jay. This Jay did teach the ehild his nngracious herexy against the blessed sacrament of the altar ; which heresy the ehild in my house began to teach another child. Ani upon that point I caused a servant of mine to stripe him like a ehild, before mine household, for amendinent of himself and ensample to others. Another was one who, after he hidd fallen into these frantic heresies, soon fell into plain frenzy; albeit that he had been in Bedlam, and afterwards by beating and correction gathered his remembrance. Being, therefore, set at liberty, his oll frenzies fell again into his head. Being informed of his relapse, I eaused him to be taken by the constables and bounded to a tree in the street. before the whole town. and there striped him till he waxed weary. Verily, Gor be thanked, I hear no harm of him now. And of all who ever came into my hand for heresy, as help me God, else had never any of them, any stripe or stroke given them, so much as a fillip in the forehead.' 
maniac, according to the received notion of the times, as a cure for his malady.'*

But the account given of his own proceedings, even by such a man as Sir Thomas More, must not be accepted as perfectly conclusive. There are, it has now been made apparent, omissions which require to be supplied. Not only does . Joye call More 'about the child a lowde lyer,' $\dagger$ but it is manifest from authentic documents that Chelsea Manor was both a court for the trial and condemnation of heretics, and a painful prisonhouse, where some of the wretched victims to merciless orthodoxy were "bound with irons so that they could not get their living after.' In his defence of his doings, More felt constrained to make the sure lieeping of heretics an exception to his wonted philanthropy. The euphemism even looks like an attempt to slur over the somewhat awkward treatment of culprits, such as the author of the 'Itopia' might well blush to own. Besides maiming some of the incarcerated in his dungeons for the remainder of their lives by the severity of the 'sure-keeping,'+ More, it must in honesty be adderl, made diligent search for the suspected by his emissaries, interrogated them with great asperity, and even when he ceased to be lord chancellor, he did not cease to be an active persecutor-he 'so hated,' as he avowed, 'that folk.' Green, the historian of the 'English People,' is of opinion that More's severity has probably been exaggerated. On the contrary, its virulence has been underrated. Green's investigations, so valuable in the general views set forth, traversed too wide a field to allow of the examination of details with close exactness.

Still, Hore compares most favourably with some of the grim prelates and bigoted laymen of his time. Stokesley dealt a culprit, whom he was examining for heresy, a blow

* Campbell's 'Lord Chancellors,' ii.. pp. 38, 39.

† See Joye's 'The Foundacion of Mlore's False Foundacion.'

¥ John Field's case shows persistent cruelty on More's part (B. vi., 1059). Also George Constantine's case (B. v., 57t, and Appendix 3t). John Tew kesbury was condemned in Sir T. Mlore's house December 16, 1531, and burned at Smithfield St. Thomas's Eve December 20 (B. v., 589). So much for the empty vaunt of Erasmus, that while More was chancellor 'no one was put to death for these pestilent dogmas.'- See B. v., 1176 .

Besides heretics, 'John Moreton, Gentilman,' insane, was enmmitted (January ․?3, 1526), with his possessions, to More's custody.-Rymer. 
with his crozier which made him swoon. Wriothesley himself, with fierce violence, racked and dislocated the delicate limbs of Anne Ascue. No such personal rough-handed cruelty sullies the gentler memory of Sir Thomas More. Harsh on himself in self-diseipline, after the example of Pico of Mirandola, his model, punishing his own body with strokes and hard fare 'like an ass, lest provender might pride it,' he spared the backs of his prisoners. And to this must be added with emphatic clearness, that in seeking out, imprisoning, condemning and burning heretics, he felt persuader, as Saul of Tarsus of old, that he was doing God service. Thus, when the bishops pressed on his aeceptance a handsome gift of money in token of his eminent deserts in their cause, he declined to accept it, quietly remarking to his intimate friends, 'I look for my thank of God, which is their better.' 


\section{X.-THE CONTROVERSI.}

IT was in June, 1529, only eight months after the publication of the 'Obedience,' that More issued his reply, a theological treatise in four books, bearing the title of a 'Dialogue.' In diplomatic fashion he supposes a friend, harassed with religious doubts, to send a 'trusty secret messenger' to him 'with a letter of credence.' A dialogue thus ensues between the messenger and Sir Thomas, who has now been elevated by Tunstal to the chair of theological umpire, and this dialogue, to be permanently and widely useful, is made into a book. Little, however, proceeds from the lips of the new theological arbiter beyond the stereotyped argument of ecclesiastical authority. 'The Church cannot err,' such was the wearisome refrain throughout, at a time when it was patent to reason and common-sense, and to the student of Scripture, that the visible body which More termed the Church had erred, and erred grievously.

The Church he defines to be "the whole common congregation of Christian people, good and bad, not separating themselves from frowardness, nor being put out for their own faults.' He condemns Tyndale's version of the New Testament, but allows the messenger to bear testimony to Tyndale's high character with many, and the good repute with many of his version. He has not found three thousand errors in it, like his friend Tunstal, but he has found one thousand, and he strongly reprobates the disuse of the ecclesiastical terms priest, church, churity, grace, confession, penance, contrition.*

The most noteworthy passage of the treatise is perhaps the

* The messenger's words are striking: 'And they thinke that for none other cause was also burned at Poule's Crosse the newe testament late translated in Englyshe by Maister William Huchin, otherwise called Maister 
following suggestion of a translation of Seripture into English under certain conditions :

'Now, if it be so, that it would haply be thought not a thing to be meetly adventured to set all on a flush at once, and dash rashly out Scripture in every rude fellow's teeth; yet, thinketh me, there might such a moderation be taken therein as neither goodly virtuous folk should lack it, nor rude and rash brams abuse it. For it might be with diligence well and truly translated by some good Catholic and well-learned man, or by divers dividing the labour among them, and after conferring their several parts together each with each. And after that might the work be allowed and approved by the ordinaries and by their authorities so put into print as that all the copies should come whole into the bishops' hands, which they may, after their discretion and wisdom, disperse to such as they perceive honest, sad and virtuous. ... And providing as much as may be that the book be, after the decease of the party, brought again and reverently restored unto the ordinary.

Even the suggestion of this carefully-regulated supply of the water of life, the key to the padloek of the sacred well to be held by the fast hand of a selfish hierarchy-to whom the salvation of souls was nothing, and their own position and emoluments everything-must be accepted as evidence of the rapid progress made towards popular enlightenment, within the little more than three years since Tyndale's version first reached London. The 'Dialogue' was patronized,

Tiudall, who was (as men saye) well knowen or he went over the sea, for a man of right gond lyving, studion and wel lerned in Seripture, and in divers places in Engliad was very wol liked, and did great gond with preching. Ant men mutter among them selfe, that the boke was not only fautles. but also very wel translated, and was deryed to be burned, becanse men should not be able to prove that such fautes (ins were at Poule's Cross declared to have be fond in it) were never fonde there in dede, but untruly surmised. And yet suche as they were (some men silye) wre no fantes at all, if they hadide be so trenslated in deede, but blame laied and fante found with thinges nothinge fante worthye, onely to deface that holy worke, to the ende that they might seme to have some juste eanse to burne it. And that for none other entent, lint for to kepe ont of the people's baites all knowledges of Christy's gospell and of Codde's law, etc.- "The Workes of Sir Thomas More, Kuyght, etc. in the Englyshe 'Tonge' (black letter). London, 1557.

* More's Workes (15,7). book iii., c. 16. p. 245. 
of course, by the prelates; and next year (1530) a second edition appeared.

Tyndale waited until June, 15:31, before he published his 'Answer' to More, whom he designated 'the common jester and scoffer,' as, later on, in a similar vein, he styled him 'Master Mocke.' Motives of expediency were the cause of the delay, especially the sincere wish to avoid giving further umbrage to the king, * who had been greatly incensed by 'Tyndale's 'Practice of Prelates.' It was published just after' the unsuccessful negotiations, conducted by Vaughan, for the translator's return to England, and was printed at Amsterdam under the supervision of Fryth, who was then living in Holland and married. Like the 'Dialogue,' Tyndale's 'Answer' also was in four books. His treatise is commended by Vaughan for moderation: but its tone and arguments are by no means wanting in characteristic vigour and sharpness.

'The Church,' Tyndale declares, 'may mean the place where now we hear but voices without significations, and buzzings, howlings and cryings, as it were the hallooings of foxes or baitings of bears; and wonder at disguisings and toys, whereof we know no meaning.'

The Church, 'in another signification, is abused and mistaken for a multitude of shaven, shorn and oiled, which we now call the spiritualty and clergy:'

Or the 'Church' has a third signitication, that of a 'congregation,' the proper rendering of the Greck term-' the whole multitude of them that believe in Christ,' in any place, 'parish, town, city, province, land, or throughout all the world, and not the spiritualty only.'

But of some of those that 'embrace the name of Christ,' the faith may be 'naught,' or they may have 'no faith at all.' Thus sometimes the Church 'is taken specially for the elect only; in whose hearts God hath written His law with His

* Vaughan was favoured with a copy - which be re-wrote for the king - previous to its publication, and assured Crumwell, March 25, 15:31, 'He (Tyndale) has never written anything with so gentle a style.'-B. v., 15:3.

A little later Vaughan wrote to Henry (April, 1531): 'He (Tyndile) told me he had finished a work against the lord chancellor's book, and would not put it in print till you bad seen it, because of your displeasure for hasty putting forth his other work (" The Practice of Prelates ").'B. v., 201., 
Holy Spirit, and given them a feeling faith of the mercy that is in Christ Jesu our Lord.'

This 'elect Church' he defines to be 'the whole multitude of repenting sinners that believe in Christ, and put their trust and confidence in the mercy of God; feeling in their hearts that God for Christ's sake loveth them, and will be, or rather is, merciful unto them; and forgiveth them their sins of which they repent; and that $\mathrm{He}$ forgiveth them also all the motives unto sin, of which they fear lest they should be drawn into $\sin$ again. And this faith they have without respect of their own deservings; yea, and for none other cause than that the merciful truth of God the Father, which eannot lie, hath so promised, and so sworn. And this faith and knowledge is everlasting life; and by this we be born anew, and made the sons of God, and obtain forgiveness of sins, and are translated from death to life, and from the wrath of God to His love and farour:'

Here, on the question, What is the Church? the divergency between the eontroversialists was fundamental. With More, the Church and her ordinances now assumed the prineipal position. And such has always been her place in the papal system. With More the (hurch was marked off by the circunscribing limit of creed and ordinances. With Tyndale, on the contrary, no ecclesiastical organization, no ordinance, no sacrament, was allowed to obscure the great centre of the whole, the living person of the Lord Jesus Christ Himself. The relation of His mystical body, the (hurch, to Him, its head and soul, was always kept in chief and essential prominence. To Him, livine and human, priest and king, all members of His spiritual body were linked by real vital faith. 'Him first, Him last, Him midst, and without end."*

But besides this essential discrepancy, there were minoi points of disagreement. His use of terms, objected to by Itore, Tyndale generally maintains. As regards 'senior' he Says; 'I spied my fault since, long ere M. More told it me, and have mended it in all the worlis which I since made, and call it an "elder.",

* In tbis line Milton adopted Luther's words: "In my heart this article reigns alone, and shall reign-faith in my dear Lord Christ, who is of all my spiritual thoughts, day and night, the beginning, and the middle, and the end.' 
'Love' he prefers to 'charity.' "When we say, "Give your alms in worship of God, and sweet St. Charity;" and when the father tcacheth his son to say, "Blessing, Father, for St. Charity," what mean they! In good faith, they wot not.'

'Favour' he prefers to 'grace.' 'In some grace there is little goodness; and when we say, "he standeth well in my lady's grace," we understand no great godly favour.'

'Knowledge' he prefers to 'confession,' and 'repentance' to 'penance.' 'The sickness that maketh them so impatient is that they have lost their juggling terms.' 'Confession,' in the sense of 'shrift in the ear,' he declares to be 'clean against the Scripture, as they use and preach it;' and 'unto God an abomination, and a foul stinking sacrifice unto the filthy idol, Priapus.' 'As for their " penance," the Scripture knoweth not of it.'

Later on in the treatise he distinguishes between an listoricul and a feeling faith and between worshipping and honouring-inquiring, as he proceeds, whether the worship done to his lord the cardinal's hat, which at Westminster had been 'set on a cupboard, and tapers about,'* and the greatest duke in the land compelled to 'make courtesy thereto,' were accorling to the subtle distinctions of Rome, doulia, leyperdoulìa, or idolatièa.

If to the departed in Christ knowledge be vouchsated of events passing on earth, what rejoicing thankfulness must have been awakened in Tyndale by subsequent translations of Scripture, and not least by the recent revision of our own Authorized Version! This revision, whatever its imperfections, certainly marks a happy advance in theological breadth. As regards Tyndale himself : after a lapse of three hundred and fifty years, gifts and acquirements which Tunstal, Fisher, and Nore were too blear-eyed to discern have met with full recognition; and the preface to the revision testities with straightforward candour: "The foundation was laid by William Tyndale; his translation of the New Testarnent was the true primary version.' Illusions of a degenerate age and a corrupt Church, to dissipate which Tyndale in a few instances

* 'Practice of Prelates,' 'Tyndale's Works, P.S., ii., p. 33!!. Singer's Cavendish's 'Wolsey,' ii., pp. 301.304. 
adopted expressions strange perhaps even to his own generation, have in our clearer spiritual atmosphere vanished; and the revision, while sanctioning some terms of the Authorized Version not strictly correct, yet now but little misunderstood, and thus but little abused, and made familiar by time, has in several points returned to the phraseology of the primary translator, and notably has restored 'love' to its own rightful place.

More was Lord Chancellor when he replied to the 'Answer' in his ' 'onfutation.' + Three books he wrote whilst still in his high oftice, and afterwards added six. The ninth-'A Rocapitulation and Summary '-is left unfinished. The first book, after reviling Tyndale, Fryth, Hytton, and Bayfield. passes on to matrimony, and reviles Luther for violating his monastic row and wedding a num; the eighth is an irrelevant digression to Barnes; the whole is verbose and tedious. More could not weave an argument so full and conclusive as to satisfy his own logical acumen and good sense, but went on arguing and 'railing' with very little stint or self-control. It is now only the laborious student, who has some vexed or curious point to ascertain, who disinters the prolix volumes from their tomb amid dust and cobwebs.

It has been the custom to assign the palm in eloquence to More, in argument to Tyndale. But it is only the eloquence of truth which is really worthy of the name. Mackintosh, whilst lamenting the deviations of More, 'alarmed by the excesses of Luther's followers,' from his fair visions in the 'Utopia,' yet pronounces him as a man 'unsurpassed since Boethius, the last sage of the ancient world,' and characterizes him as 'the first Englishman who signalized himself as an orator, and the first writer of a prose which is still intelligible. ${ }_{*}^{*}$ More's

\footnotetext{
* Add virtue, patience, temperance ; add love.

By name to come call'd ebarity, the soul

of all the rest.'-Milton.
}

† 'The Cofutacion' was 'Prentyd at London by Will. Rastell, 1532,' in folio.

More's 'Workes' were published collectively in 1557, and dedicated to Queen IIary. The editor was William Rastell, sergeant-at-law, the son, provably, of the Will. Rastell by whom the 'Confutition' had been printed originally.

+ Mackintosh's 'England, ii., l!!. 170-17\%. 
style is in truth stately, bespeaking a chancellor, yet somewhat verbose and tedious. Wolsey and Henry himself both wrote their native language with force and clearness, as their correspondence shows. Certainly no treatise in English has come down to us from the pen of either. But Tyndale was an author like More. He wrote, indeed, for a different class of readers; but his diction is always intelligible, and even perspicuous. To 'Tyndale, moreover, belongs the yet higher honour of having fixed by his translation the standard of the English tongue. The vigorous Saxon of his Biblical versions may be superior to the language of his treatises, for in translating Scripture he was raised above himself by the ennobling consciousness of the supreme dignity of the task. But the clear pithy style even of his treatises may compare with the Saxon homespun of Defoe or Bunyan. Unhappily from the reproach of coarse vituperation, neither of the two antagonists, with any basis of truth, can plead exemption. In this old-fashioned department of literature, whether of the two outdid the other is alone open to question.

Of More's coarse vituperation let a few specimens suffice. He states that Wycliffe ' purposely corrupted the holy text.' He calls Luther ' a fond friar, an apostate, an open incestuous lechour, a plain limb of the devil, a manifest messenger of hell.' Amongst other charges he blames him for teaching that men should go to Mass as well after supper as before breakfast.' Tyndale he vilifies as 'worse in some parts than his Maister Luther' is himself_-'draff for the hogs of hell.' 'I marvel,' wrote More, 'why Tyndale fear so little the fire of purgatory, but if (unless) he be at plain point with himself to go straight to hell.' Tyndale's translation was like a 'false copper groat silvered over to look like a true silver groat.' 'To bum heretics he pronounced 'lawful, necessary and well done:' it was destroying the 'ravenous wolves that devour the flock.'* similar amenities of Tyndale will appear hereafter.

It is impossible to enter the old church at Chelsea, haunted as it is by many memories, without vividly recalling with especial interest the personal and domestic, as well as the public, history of the great Lord Chancellor who accepted that

* See More's 'Workes' (1557), pp. 220, 229, 239, 247, 274, etc. 
high office on the royal assurance that, in diseharging its functions, he was 'first to look upon God, and after God upon the king.' No worldly business was ever allowed to interfere with the regular attendance of himself and his household in its hallowed courts. He himself bore, in eonjunetion with his intimate friend, 1)r. Larke, the parson, who 'suffered quickly" after him in the inatter of the supremacy,' a prominent part in the religious services, walking in processions at the head of the church choir, and bearing a cross. It is related that onee More's friend, the Duke of Norfolk, ' eoming to Chelsea to dine with him, fortuned to find him at the ehurch, in the choir, with a surpliee on his back, singing; to whom, after service, as they went homeward together, arm-in-arm, the duke said, 'Godsbody! Godsbody! my Lord Chancellor a parish clerk: a parish elerk!' 'Your grace may not think,' replied More, 'that I dishonour my prinee in my dutifulness to his Lord and ours.' The south ehancel of the ehurch was ereeted by More, who, removing thither, buried beneath its pavement the bones of his first wife, ${ }^{*}$ and placed in its wall, while he yet lived, a memorial to himself, surmounted by his erest, a Moor's head. The interest of the pilgrim-visitor will be all the elearer and fresher beeause, happily, the vandal hand of so-ealled restoration has hitherto spared the sacred structure.

On the memorial stone slab there is a Latin inseriptionhis own composition in 1532-which transmits to posterity what he must have deemed no trivial encomium, that he was 'a trouble (molestus) to thieves, murderers, and hereties.' $\dagger$ In reentting this inseription, the last word-last and worst in the seale of infamy-has been left blank so as to be almost illegible. Many of his admirers would ignore his conseientious persistence in perseeuting intoleranee. But no disparagement

* "In the metrical inseription which he wrote for his own monument. there is a laboured commentation of Alice, which in tenderness is out weighed by one word applied to Jane:

"Chatra Thoma jacet hic Joanua urorcula Mori.",

-Campbell's 'Chancellors,' ii., p. 14, note.

$\uparrow$ Nore wrote to Erasmus: "I have purposely stated in my epitaph that I molested heretics, for I do so hate that folk, that, unless the repent, I would rather incur their animosity, so misehievous are they ti the world.-B. vi., 303. 
to his merits has this sole stain on an illustrious career proved in the judgment of that Apostate Church which speaks of persecution with 'bated breath, in this more enlightened age, only because her arm is palsied; for she boasts to be unchanged and unchangeable, and has recently beatified him-a prelude, it may be, to canonization-together with his friend Fisher.

Strangely enough, a mural tablet to a Tyndale looks down from a corner above upon More's memorial. 'A significant allegorical record' this, remarks Demaus, of the result of the controversy. Alas! history presents few more melancholy scenes than the embittered wranglings and coarse vituperations of men good and true, unable to discover any excellence in another, from whom there is the fundamental estrangement of religious difference. Certainly here is, at least, an undeniable tribute to the supremacy of the religious principle. In this case the antagonists, both of moral purity, unsullied by the slightest taint, both, finally, martyrs to convictions held dearer than life, both now deservedly high on their country's scroll of fame, have long since met-however foully they vilified one another on earth-in the presence of Him in whom all divergences of earnest faith find their reconciliation for ever. They are now beyond the mist and clouds which bewilder and mislead even the most clear-sighted of fallible mortals.

The refugee translator in his earthly lot had indeed 'fall'n on evil days and evil tongues.' There has been a great awakening-during little more, however, than the last halfcentury - to a more just sense of his true merits. Monuments have been raised to his sacred memory near the spot of his birth, and in the Metropolis, where and whence his New Testament circulated. Yet, however right the spirit dictating at last such recognition, his real monument-more lasting than the tower on Nibley Knoll, and more expressive than the bronze statue on the Victoria Embankment, where, in upright figure, in the same garden enclosure as the chivalrous Outram and the able Sir Bartle Frere, on their right hand, as though he were their leader (as indeed he was) he stands in learned gown facing the river up which Flemish vessels wafted the volume of life, his hard-bought gift to his country- 
men in their own tongue* -will ever be the monument which he has himself reared to the honour of his Master: his plain and manly version of the inspired book, the common heritage of our English-speaking race, and part in very truth of our spiritual life-blood, both in the mother country and in whatever remotest corner of the earth British energy may found a home.

* The inscription on his statue-after texts cited from his versionbears the following :

'The last words of William Tyndale were :

"Lord! open the King of England's eyes."

Within a year afterwards

A Bible was placed in every

Parish Church by the King's command. 



\section{TABLE OF DATES.}

1527. Henry cited by Wolsey for cohabiting with Arthur's widow, 17 May. Wolsey goes to France as Henry's lieutenant, July.

1528. Wolsey's offence as regards the Abbess of Wilton. Cardinal College. Salt-fish Cellar tragedy. A sickly time. Pestilence in Lautrec's army before Naples. Campeggio reaches London, October.

1529. Clement ill. Reported dead, Jannary. Henry's writ for the legates to try the cause, 30 May. The court opened, 18 June. Memorable scene, 21 June. The court prorogued, 23 July. The Treaty of Cambray. Wolsey surrenders the sєal, 17 October. Parliament meets, 3 November.

1530. Wiltshire's embassy to Charles V. Charles crowned by Clement at Bologna, 24 February. The first papal brief to Henry, 7 March. French princes liberated, July. Verdict of University of Paris for Henry. Wolsey dies, 29 November.

1531. The second papal brief to Henry, 5 January. Henry sole head of the Church, 'after God,' February. Bilney burned, 19 August.

1532. Act in restraint of annates, 19 March. 'Submission of clergy,' 16 May. Sir T. More resigns the seal. Henry meets Francis at Calais, October. The third pajal brief to IIenry, 15 November.

1533. Henry marries Anne, 25 January. Cranmer primate, 31 March. Cranmer pronounces the marriage with Anne valid, May. Anne crowned, 1 June (Whit Sunday). Fryth burned at Smithfield, 4 July. Clement excommunicates Henry conditionally, 11 July. Elizabeth (the future queen) born 7 September. Clement and Francis meet at Marseilles, November.

1534. Clement declares the marriage with Katharine valid, and excommunicates Henry, 23 March. The Act of Succession. Parliament prorogued. The Settlement receives signature. Elizabeth Barton suffers, 20 April. The Act of Royal Supremacy, 3 November. 


\title{
BOOK IV.
}

\author{
SEPARATION FROM ROME.
}

\section{I.-ENGLAND'S FOREITN RELATIONS.}

Whes Tyndale's version of the New Testament was on English soil, and becoming domiciled in English homes and hearts, the first stage in the progress of the Reformation was approaching completeness. The next stage was the deliverance of our Church and nation from the tyrannical and arrogant yoke of a foreign spiritual power. In effecting this emancipation, the principal instrument of Providence was the king himself; who, although he never disentangled his feet from the mire of Romish dogma, yet, at last, with peremptory resolution, shook for ever from his crown and realm the insolent thraldom of Roman supremacy. Through what causes he was at length compelled, contrary to the force of long-cherished habit and rooted prejudice, to carry to the end this national deliverance, is an interesting and instructive chapter in the records of God's dealings with England. But before entering upon this subject, it will be necessary to give some brief attention to public events big with momentous consequences, and to the varying relations of our country at this epoch to foreign Powers.

Arthur of Winchester, eldest son of Henry VII., had been married, when only sixteen years and two months old, to Katharine (Catalina), fourth daughter of Ferdinand of Aragon and Isabella of Castile. The marriage cerenony took place in St. Paul's, Sunday, November 14, 1501, amid the rejoicings of the nation. The alliance with spain, ' ancicnt out of mind,' 
was popular; and Katharine, although, according to the report sent to Venice,* ' of low stature and rather stout,' yet had a prepossessing 'modest countenance,' and was 'replete with goodness and religion,' and by her fair hair and biue eyes reminded her new countrymer that the blood of the House of Lancaster ran in her veins. Arthur settled on his wife a third of his goods and rents; and when the royal pair were believed to be canonically man and wife, the half of Katharine's dower (200,000 scudi in all) was paid down.

Towards the close of December the newly-wedded pair moved north-westwards to Ludlow Castle, on the borders of Wales; for Arthur, it was fondly hoped, would revive the glories of the British prince whom he resembled in name and race, legends respecting whom had recently been given to the world by Caxton. Here with his bride Arthur kept his court. But April had only just dawned when the "shadowy knight of Camelot,' wasting in rapid decline from a clill caught in a dripping winter, passed henee to the world of realities. He had not been a husband quite five months.

Before Katharine's first marriage, the fears of Ferdinand and Isabella in regard to their daughter's succession had been quieted by the execution, with 'Spanish ruthlessness,' of the poor imbecile Warwick (November 2\&, 1499), the last male Plantagenet, the son of Clarence, on the flimsy pretence that he had been concerned in a conspiracy in conjunction with Perkin Warbeck, his eompanion in the elosing months of his fifteen years' eaptivity in the Tower. And now, on Arthur's demise, the anxiety of her parents returned in full force, that their daughter should yet be Queen of England. $†$ The alliance, too, of England they judged to be of value in the impending contest with France for the possession of Southern Italy, to which Ferdinand laid claim as King of Aragon. They had obtained a hold on Henry by having in

* Ven., iv. 694.

$\dagger$ Fox, Bishop of Winchester, examined April, 1527, when seventynine years old, in the Castle of Wolvesay, in Winchester, stated : 'Is not certain whether Henry VII. proposed the second marriage. Thinks it was done by Dr. Peohebla (Puebla, the Spanish ambassador). Believes that various Bulls were obtained, two of which remain in England, and one or two in Spain, all of the same tenor.'--B. iv., part iii., 5791. 
their power Edmund de la Pole, a son of John de la P'ole, Duke of Suffolk, by Elizabeth, sister of Edward IV. Edmund, on Irarwicks execution, had fled to Flanders. Henry, on his part, besides the desire to perpetuate his dynasty, was loth to resign Katharine's dower and her jointure as Arthur's widow, and was, moreover, cautious of alienating spain.

The reigning pontiff at this time was Julius II., who felt reluctant to sanction the wedlock of Katharine and young Henry, inasmuch as they were related in the first degree. But here, too, Isabella had ready to her use a conclusive argument; for she held in captivity Cesar Borgia, the infamous son of the infamous predecessor of Julius, and of all men the most dreaded by him. The victories, too, of Spain in Southern Italy added weight to the Spanish demand.

It is related that Isabella, whose health was fast failing, even from her chamber of sickness, by earnest entreaties and solemn promises of strict secrecy, contrived not only to obtain. the consent of Julius to the second wedlock, but even suc. ceeded in having the dispensation committed to her own eager hands. Promises were then scattered to the winds. The papal document was displayed to her council, and to the chiefs of all the orders of her kingdom. And the object desired by the Catholic sovereigns was so far achieved that Henry, Prince of Wales, when about twelve years of age, was betrothed to his brother's widow, rather more than five years his senior. After no long interval Isabella herself had gone (November 25, 1504) to her account.

Elizabeth the Good had preceded her to the tomb, having died in childbed (February 11, 15(1)3) on the very day that she completed her thirty-seventh year. The illness of her widowed consort, which followed, increased the apprehension that the anger of Heaven had been provoked. 'Thus Henry VII., alike superstitious and politic, swayed by various motives, having secured possession of Katharine and her valuables, and maintained peace both with Spain and with France, directed his son and heir. on attaining fourteen years of age, to make a formal protest against being bound by his marriage contract.*

* See the Protest (B. iv., part iii., 5791) in Herbert. 
Henry treated his daughter-in-law with rigour; and if he actually prohibited his son from holding intercourse with her, such restriction would be likely to render a young prince as selfwilled as Henry afterwards showed himself to be, better disposed to the match. Katharine, on her part, thought that there was not such a paragon in the world as the Prince of Wales. She loved the blue-eyed, elear-skinned, ruddy, stalwart boy, handsome among the handsomest, or, rather, as the Venetian ambassador reported, 'angelieal,' much resembling in person his srandfather, Edward IV., and towering, like another Saul, above his nobility. His beauty at this period was unimpaired hy the premature baldness which showed itself a few years later. He possessed more important advantages than good looks and tall stature. He was the first English sovereign, since Richard II., who had mounted the throne with an undisputed title. His manners, if brusque, were hearty: and with his courtiers he was nore of a eompanion than a king. In mind, he has been rleseribed by Erasmus as a 'universal genius'; no mean proficient in musie and mathematics; elever in disputation, with rather more than a smattering of scholastic theology.

Searcely had the father's remains been laid to rest by the sirle of the good queen, in the noble ehapel added by him, in compliance with his native artistic taste, to the great abbey, than the nuptials of the royal couple were already engaging attention. Henry inquired of his comneil whether it was lawful for him to wed his brother's widow. But his own mind was already made up, and early in .June, 1509, a few days before his eighteenth birthday - which fell on the 2 sth day of the same month-he was privately united in matrimony to Katharine at (rreenwich, in the queen's closet.

In due time children were born to them. First a still-born daughter; then, on New Year's Day, 1511, to the loud joy of the nation, a prince, who deceased, however, after the brief span of a few weeks; then another prince, who outlived his birth but a few days; then, in 1514, a prince born prematurely. At length, after njwards of six wedded years, a daughterMary-gladdened (February 16, 1516) the hearts and hopes of the royal pair. A girl followed two years and a half later, 
who did not survive her birth. Mary alone remained, 'the last green branch of a withered tree.' Awestruck at the apparent displeasure of Heaven, Katharine lamented that her first wedlock had been 'made in blood.'

Meanwhile, the relations of England to foreign Powers had undergone a change.

The idea of a crusade for the recovery of the Holy sepulchre, for peace in Christendom, and the discomfiture of the Turk, - whose encroachments were the nightmare of Europe-had early fascinated the imagination of young Henry. The enterprise befitted his character as a soldier and a true son of the Church, and had been pressed upon him by his father's dying words. But ere such a difficult scheme could be undertaken the war against France must be concluded. This itself might be regarded as a holy war, inasmuch as France had conspired against Venice, the bulwark of Christendom, and, under the popular Cardinal d'Amboise, had betrayed tendencies which seemed to point to a reformation of religion. The rapid growth of France, too, was a universal menace. Guienne had fallen to Charles VII.; Provence, Roussillon, Burgundy had augmented the dominions of Louis XI.; Britany had been annexed to the realm of Charles VIII. by marriage; and this valuable addition to his territories Louis XII. had been able to retain by the pontifical sanction of a divorce and marriage for political ends. Europe had trembled when Charles VIII. crossed the Alps; and his successor, Louis XII., still retained Milan, and enjoyed extensive inHuence in Northern Italy. It was little surprising, then, that Henry was willing to second his father-in-law's opposition to French ascendancy, although the favourers of the New Learning raised high their voice in denunciation of war, condemning especially its retarding influence on social progress; and Colet declaimed that an unjust peace is preferable to a just war.

In this war against France, England had as allies Venice, Spain and Austria, with the pontiff himself at the head of the League, thus named Holy. At first Henry's expectations were disappointed by the mutinous withdrawal of English troops from Gascony. But fortune smiled on his next essays. The 
battle of Guinegate, or 'the Spurs' (August, 1.51:3), flattered' his youthful vanity and his yearning for military renown. It gratified his pride that Maximilian submitted to serve under his standard for one hundred crowns a day, and that Bayard, famed everywhere as the knight 'without fear and without reproach,' was among his prisoners.

But when he at length discerned that his wily father-in-law was pursuing schemes of selfish ambition under the ostentatious guise of piety, was retaining Navarre-through which alone France could invade spain-in his treacherous grasp, and altogether was merely playing with his son-in-law's filial reverence and simple earnestness, his indignation broke through all restraint. The way was thus paved for peace with France. The dissolution of the Holy Leagne left Henry to his own plans. Shortly afterwards it beeame apparent that Ferdinand and Maxmilian, after fifteen years of bloody warfare, were veering round towards a reconciliation with Louis, and were listening to proposals for a marriage between their grandson, the Arehduke Charles, who had been pledged to Henry's sister, and a daughter of Jouis. Henry now therefore himself made peace with France; and, according to custom, the peace was to be cemented by a marriage. The marriage contract, therefore, entered into (1507) between the Arehduke and Mary Tudor was annulled; and Mary, in the bloom of girlish beanty, was escorted by Norfolk into France and married to Louis XII., fifty-three years old, and older yet in physical constitution.

Little satisfied was Mary with Norfolk; she would have preferred Wolsey as her escort; and so she wrote to her brother. This French marriage was important for England, which had been but a second-rate P'ower, under the dictation of Ferdinand. But on New Year's 1)ay, 1515, Lonis, the father of his people, departed this life, his intirmitics having been aggravated, it was said, by the dissipated life introdueed by his youthful queen.* The Duke of Angoulême, his eousin,

* 'Ou il avait coutume de diner a huite heures, convenoit qu'il dinât a midi ; on il avait contume de se concher a six heures du soir, souvent se couchoit a minuit.'--Quoted by Duruy, 'Hist. de France,' i., p. 6:37. In 
succeeded him on the throne as Francis I., when he was only twenty years of age.

A year later the hand of death (January 23, 15l6) removed Ferdinand from his selfish and crafty projects. And thus his grandson, by the decease of his father, Philip the Handsome, heir of the Netherlands and Franche Comté-the dower of Mary of Burgundy, his grandmother-and already King of Castile in conjunction with his mother Juana, became now, at sixteen years of age, king of all the Spains, inclusive of Naples and vast dominions across the Atlantic. Three years later the death of Maximilian (January 12, 1519), his paternal grandfather, transmitted to Charles his heritage in Austria, Swabia, and on the Danube. And shortly afterwards there was a fresh accession to his roll-call of crowns: for he was elected Emperor of Germany (June 28, 1519), overcoming the competition of Francis, as being not only sufficiently powerful to deliver Europe from the Turkish inroads, but also himself by descent a German. To his Spanish subjects it was a mortifying annoyance that Charles accepted the imperial diadem. He now assumed the new style of 'majesty,' in adopting which he was quickly imitated by feebler sovereigns. Never before, for many centuries at least, had sceptres so numerous and so splendid met in one hand. He held the civilized world, it was said, 'by its four corners.'

Of course the interests of peace were in dire jeopardy. This was but too obvious. Francis could ill brook the preference evinced by the German electors for his formidable rival. He had won high military repute by his victory in 'the battle of giants' at Marignano (September 13, 1515), where the French had defeated in the second day's combat the Swiss, before thought invincible, through the opportune arrival of the Venetians. This success, thus early in his reign, gave the Milanese to Francis, and revived the dread before inspired throughout Europe by French ambition. The dominions of Francis, although less extensive than those of Charles, were

that age the early meal was termed 'dinner,' the later 'supper.' Thus : 'Come and dine,' 'When they had dined'-the meal being in the very .early morning-John xxi. 12, 15 , Authorized Version.? 
far more concentrated and rich by the bounty of nature. Alarming symptoms manifested themselves, that the conflict, which threatened to be as tremendous as it was inevitable, could not be postponed to any very distant date. For Francis, in his chagrin at being rejected by the German electors, had already forgotten the Treaty of Noyon-signed only 1516, when (harles inherited the throne of spain-and had demanded back Naples, and required homage as feudal superior for Flanders. Charles, on the other hand, laid claim to Burgundy ar well as the Milanese. It was a matter of busy speculation to which side the King of England would attach himself in the impending struggle : for between the angry and powerful rivals his favour seemer likely to determine the almost equal scales.

Wolsey had now succeeded his patron Fox in directing English policy. His plans for the most part consistently aimed to uphold the European balance. But besides antipathy to the dangerous aggrandizement of the victor of Marignano, he himself aspired to St. Peter's chair: and to secure this, his fondest hope, he had received the promise of the emperor's aid. Francis, a warm patron of the tine arts, and the accomplished Henry had many pursuits and tastes in common. On ' the field of the cloth of gold,' at ('ruisnes (June 7, 1.520), where Wolsey's genius, as skilful to plan a ceremonial as to rule a kingdom, shone in every variety of boundless display, they contended together in pacific rivalry-in feasts, pageants, and athletic contests. But the good-fellowship promoted by such costly merriment was quickly countervailed in a private interview which followed between the mele and nephew at Gravelines. Here the youthful but artful emperor contrived to draw over to his own side the King of England's decided preference. Charles had before penetrated his uncle's political aims and regrets when he visited him in England; he saw that, like his grandfather, Edward IV, he was nursing the old grudge against the french monarch, was chating at the loss of Normandy and Guiemne, and was yearning to regain the provinces in France which had formerly given its chief lustre to the English crown. He used this knowledge as a ready key to his uncle's confidence. At the same time he held the 
aspiring Wolsey in leading-strings by the lure of St. Peter's chair.

The youth, born just as the century commenced, and freshly emancipated from the tutelage of Chièvres and the lessons of Adrian, early exhibited convincing signs of his precocious genius for diplomacy and politics. Henry might jest at his nephew's ignorance of Latin and lack of literary culture. It was to the advantage of the slenderly-taught youth, in the conferences between them, that his uncle was unconscious of his own inferiority in the arts of statesmanship. The King of England's vaunt of learning and claim to theological acumen Charles was willing to allow without the faintest temptation to envy.

Here Henry differed from the two other distinguished contemporary sovereigns. It had an important bearing upon his future career, and his achievement for his country of a momentous national blessing, and was fully in harmony with the spirit of the time, in which the New Learning both flourished and was impressing its stamp, that Henry conceived himself to be endowed with eminent skill for theological disquisition. It was a unique distinction to intertwine the crown with the ivy wreath. The controversy which under Luther's teaching was embroiling Christendom, was occupying, from various points of interest, the thoughts of all classes, learned and unlearned; and Henry stood forth before his subjects and all Europe as the uncompromising champion of the assailed papacy. He gave to the world a book which was entitled an 'Assertion of the Seven Sacraments,'* in contravention of Luther's tenets propounded in his 'Babylonian Captivity.' 'To his doctrine on the sacraments Henry consistently held fast for the rest of his life; but from assigning universal pre-eminence to the pontiff he subsequently receded conspicuously. That the King of England should uphold the extreme pretensions of Christ's vicar elicited a private remonstrance at this date from Sir Thomas More, as he himself after-

* Assertio vii. Sacramentorum, adversus Martinum Lutherum. Edita ab invictissimo Angliæ et Franciæ Rege, et Domino Hyberniæ, Heurico ejus nominis octavo. In Edibus Pynsonianis, apud inclytam urbem Londinium, 1521." 
wards stated.* Henry replied that he had good reasons for loing as he had done. Perhaps he anticipated that objections might be raised by-and-by to the Prineess Mary's legitimacy, in which eave the pontifical goodwill might be of great service. 'From that see,' observed the king, 'we received our erown imperial;' which, remarked Ilore in detailing the conversation, 'I never heard of before, till his grace told it me with his own anouth.' $\dagger$

The treatise had what some would call the merit of ehanging Sir Thomas More's opinion in regard to the pope's primacy; and gave also 'a new tone to the age, and a sharper edge to eeclesiastical discipline.' But as a theological work, although not destitute of polemical ingenuity in argument, it misser the main point. It was hailed as a prodigy. To the Germans especially it appeared marvellous that a crowned head should contain so much learning. It was presented to Leo in full consistory, and was ranked by him with the writings of Jerome and Augustine, and even declared to be dietated by immerliate inspiration. Aceording to Rome's fashion, the title of befonder of the Faith rewarded the royal eontroversialist; who, after all, was rather editor than author, for on More's evidence, Fisher and Lee were 'the makers of the same,' and Nore himeelf ' a sorter out and placer of the prineipal matters.' The Bull conferring the new title (dated October 11, 1521) was conveyed to Henry by Wolsey with all the fulsome parade and pomps wherewith Franeis would welcome to one of his châteanx a painting by Raffaello.

Alrealy had the furious struggle of the royal rivals eommeneed-to prevent which, ostensibly at least, Wolsey proceeded to (alais and engaged in conferences (August, 1521) as mediator; seeretly, however, using the oceasion to form another and firmer league between his master and Charles.

* See More's lettre to Crumwell.-B. vii., „289.

+ Singer's Roper's 'More,' p. 66 .

+ Yet Erasmus believed, or affected to believe, that Henry himself was 'parent and author.' 'His father,' he wrote, 'was a man of the nicest judgment; lis mother possessed the somndest intellect, etc. When the king wis no more than a child he was set to study. IIe had a vivid and active miud,'-B. iv., part iii., 5412.

$\$$ See Tyndale's account: Works, P.S., ii., pp. 338, 339. Holinshed, iv., Y. S., 
As the eontliet progressed, the probalility was more and more passing into eertainty, that the emperor would come off the superior. The Freneh were losing hold on Italy. Lautrec (Odet de Foix, brother of the Countess de Chateanbriant, a favourite mistress of Francis) was yielding ground to Pescara. But meanwhile Wolsey was acquiring, through the sad teaching of disappointment, a true lesson of the small value to be set upon the imperial word. Leo had reeeived, about the close of November, the weleome intelligence that the Imperialists had entered Milan. Rome was gayer than her wont with festive rejoieings, amid which, struek down Deeember 2, 1521, despite the propitious progress of his p.litieal plans, with sudden sickness-'fading,' says Ranke, 'like the poppy"-Leo expired. Yet the vacant tiara was not set on Wolsey's head, but on the unwilling head of Adrian of Utreeht, who had been the emperor's tutor. Adrian was sixty-three years of age, and was at the time of his eleetion regent for Charles in Spain, in which post he had exhibited much virtue, but had only shown sagaeity in giving way to the lead of the more gifted Nimenes. Adrian did not live to bear the unequal burden of his uneongenial dignity two full years. But again Wolsey was passed over, and Giulio de' Medici, a natural son of Giuliano, brother of the magnificent Lorenzo, was (November, 152:3) elected pontift.

Yet Wolsey continued apparently hearty in humouring Henry's day-dream of dispossessing Francis, and himself mounting the French throne. And the crisis for France and Francis was no doubt perilous, somewhat resembling the erisis which fifty years before had called into full exercise all the resources of calculation and eontrivance of the subtle Louis XI., under the coalition of Edward IV. of England and Charles of Burgundy. The Constable Bourbon, a feudal prince-of vast possessions, and much such as the Juke of Britany or the Duke of Burgundy in former years-had been enraged at being defeated in an important law-suit by the unjust verdict of Antoine du Prat, the ehancellor, at the instigation of Louise, the king's mother. Louise, from being enamoured of the constable, on his repelling her, and adding to his repulse personal remarks more true than flattering, had 
become his deadliest foe. In this posture of affairs Bourbon formed the resolution (152:3) to revolt from Francis, and had even received from Charles the promise of Dauphiny, Provence and the Lyonnese, to be constituted a separate kingdom, as the price of treachery. A scheme of partition was framed: Burgundy was allotted to Charles, the western provinces to Henry. It was suspected, however, that the emperor really coveted far more than the portion assigned to him. A treaty for the invasion of France upon such a partition compact was signed May 2t, 152t, by Charles and Henry.

Bourbon, too, was regarded as a principal contractor. $\mathrm{He}$ was to invade Provence, and thenee to extend the terror of his arms as far as l'aris itself. But he was required to take the oath of fidelity to Henry as King of France. This he was reluctant to do; int although unwilling to hold the promised provinces of Henry as feudal superior, he professed himself quite ready to hold his future kingdom of Charles.* $\mathrm{He}$ asserted, however, that he entertained no question whatever of the King of England's success. If the English monarch would "withont delay enter France in person, he would give him leave to pluek out his eyes if he were not lord of Paris by Allhallow ] lay, and then all the realm would be his.' But rivalries between the generals, personal and national-Bourbon French, Lamoy Flemish, Pescara Italian-as well as jealousies between the crowned heads themselves, interposed insuperable obstacles to effective eo-operation. Charles and Henry alike failed to execute the tasks to which they were bound by treaty.

Bourbon, on his part, was not wanting in prompt energy. He advanced through Trovence, and reeeived the surrender of town after town as he appeared before the walls. At last the imperial forces, by the direction of Charles himself - who, with seltish poliey, desired to link his kingdom of spain with his Italian possessions-laid siege to Marseilles. Stubborn difticnlties, lowever, were experienced, chicfly through the pay of the trops leing very much in arrear. Applieation was marle to England for peemiary assistance. And it was at this juncture that Woley deliberately threw oft the mask,

$$
\text { * B. ir., part i., 37!, 4.21-426,511\%. }
$$


and replied bluntly that the king had other things to do with his money than to spend it for the pleasure of four such persons as the 'ribald Nargaret, the child Ferdinand, the liar. Charles, and the traitor Bourbon.' Mutinous for pay, the imperial soldiers broke up their camp (September 27, 1524) and withrlew to Nice. Francis, on his side, now set all calculation at defiance by an exploit of unusual daring, or, rather, as it seemed, of wild temerity. In the extreme peril of his realm he had assembled considerable forces at Lyons; and now with these, not satisfied with the retreat of Bourbon's soldiers from French territory, and unmoved by the remonstrances of Louise, he crossed Mont Cenis in the autumn, made a sudden descent into the plains of Lombardy, and easily captured Milan. The Imperialists had retired to Lodi on the Adda; but instead of pursuing them, Francis, by the weak counsel of Bonnivet, who proved his evil genius, laid siege to Pavia. But Pavia was strongly fortified; his intention of diverting the Ticino was frustrated by torrents of rain; and in successive assaults he sacrificed the flower of his army. Yet Francis still persisted in the siege; he had vowed to take Pavia, and with romantic persistence was resolved to keep his vow. Undaunted by repulses, he despatched a considerable force, even under his present disappointing circumstances, with the Duke of Albany as their leader, to attack Naples.

Meantime Wolsey had been carrying on secret negotiations with Louise; but with all his craft he had not been able to veil his proceedings entirely from the outer world. Bourbon acknowledged his own profound astonishment, when he received information that a friar had been sent into England by Louise the better to maintain close communication with the cardinal. And already the deep-laid schemes of Louise, who had been appointed regent by her son in his absence, and the English minister were fast maturing, when the tide of fortune was turning more decidedly than ever in favour of the emperor. Even as early as June, 1524, John Joachin Passano (de Vaux), a Genoese in the employ of France, had been hidden in the house of Dr. Larke, a prebendary of St. Stephen's, residing at Battersea, the better to carry on confidential negotiations with the cardinal. $\Lambda$ 
little later another French diplomatist, Brinon, President of Rouen, was sent to England to contribute his advice. Joachim has been deseribed as 'the craftiest fellow, only somewhat 'too cold,' a ' noiseless' envoy ;* but his movements did not elude the notice of De Praet, the imperial ambassador, who could shrewdly guess the drift of the mysterious interviews. And Charles himself commented in his despatehes on the extraordinary circumstance of Joachim's presence at the court of a sovereign ostensibly in alliance with him. In reply it was alleged that preliminary arrangements for a universal peace formed the momentous topic of discussion.

And soon tidings of an unlooked-for event of extreme consequence startled all Europe. Before the walls of Pavia, 1525 , on February 24, St. Matthias' Day, memorable also as the birthday of Charles, in a midnight conflict, the army of Francis, hemmed in between the garrison under Antonio de Leyva in the city, and the forces under lescara and Lannoy, to whom Bourbon had now joined himself with 12,000 Germans, outside, sustained a total defeat through the abandonment of their post by the swiss. $†$ Francis himself, after a valiant fight, wounded in the hand and face, his horse killed under him, was taken prisoner. To Bourbon he refused to surrender his sword, but surrendered it to Lannoy. In the age of Bayard the spirit of ehivalry yet survived in the vigour of a green old age, and the royal prisoner in his humiliation was treated with every mark of the highest honour. Conveyed with all courtesy and respect into the eity which he had long beleaguered, and seated at table, Francis was waited upon as a king by Charles de Lannoy and the luke of Bourbon. The sixteenth century seemed in touch with the fourteenth, the duke and viceroy emulating the Black Prince, who har stood behind the chair of $\mathrm{King}$ John at the supper on the field of Poitiers.

The triumph of the imperial arms now seemed complete thus early in 1.5.5; and Henry himself, as the ally of Charles

* B. iv., part i., 271-275, tixt, 75.2, 760, $8+1,1160$.

$\dagger$ B. jv., part i., 112:3, 1124, 11is, $1164,11 \%$. Prescott and Robertson's 'Charles V.,'i., p. 379, etc. Tyndale states that the French were negligent, and went the same night a mumming that bourbon set upon them. - Works, P.s., ii., p.:31s. 
-tricked as he had been, yet still sanguine-warmed with the prospect of regaining some, at least, of the ancient French dominions of his Angevin predecessors. He sent Tunstal to Charles, the cardinal himself being 'grown now to great age' -he was fifty-four years old-and urged that Francis and his succession should be 'utterly abolished.' Would the emperor make an invasion of France in person, and meet Henry at Paris ?* Wolsey, however, who had other reasons besides his extreme age for staying at home, was guided by a more correct impression of the emperor's real purposes. Charles failed to recollect his treaty engagements when the hour had arrived for their fulfilment; and no more intended to raise Henry to the French throne, or to help him to a single French province, than he had before intended to make the Cardinal of York pontiff.

It was just before the sudden catastrophe at Pavia-in order to cover his questionable negotiations with Joachim, and to turn the tables on De Prait, and probably to gratify his ill-will by flinging contempt at the trickster Charlesthat the cardinal ordered the abrupt seizure of the imperial despatches. The privy watch riding to Brentford after midnight, February 11, 1525, intercepted the messenger with a packet of letters written in French, 'closed and sealed.' The packet was opened as very suspicious, and then was taken by the constables to a man of law's clerk. from whom it found its way to the king's solicitor, and was by him placed in the hand of Sir Thomas Hore. The next morning it was delivered by More, all opened, to INolsey himself in the Chancery. $†$

The cardinal immediately summoned De Praët before the council, taxed him with untruthfulness, and directed him to keep his house until the appointment of his successor. In his reply, De Praët made allusion to .Joachim's continued

* B. iv., part i.. 1212, 1301.

$\dagger$ Afterwards Charles accused Henry of entertaining Joachim for a year, and of opening his ambassador's letters. Wolsey alleged in selfexculpation: 'It has been frequently reported that De Praët made sinister reports,' etc.-B. iv., part i., 256, 297, 304, 330, 331, 1083, 1154, 1213 ; part ii., 3844.

The privy-watch was Wolsey's own creation.-B. iv., part iii., 5750. 
presence, and mentioned other grievances. The despatches, according to Wolsey's representations, had been opened by a 'fortunate error.' 'This was an insulting apology, which De Praët treated with disdain. Their contents breathed little love for England, and a keenly vindictive spirit towards Wolsey himself. 'I hope one day,' wrote De Praët, ' to see our master avenged; for Wolsey is the main cause of all his misfortunes.' Such sentiments coloured the ambassador's correspondence. Perhaps the strangest part of the whole incident is, that this unprecedented breach of the law of nations was stoutly defended by Henry himself.

Madrid was in a storm of indignation; the emperor alone retained his habitual self-control. He warned De Praët to conceal his displeasure; he "would himself complain to the king; he wished some good means might be found to punish the cardinal.'* His real sense of the insult he more clearly signified afterwards, when he appointed De Praët his ambassador at Rome, and then in France, with strong expressions of his entire confidence in him. But with England Charles conld not afford to quarrel at the present juncture. The pay of his troops was many months in arrear ; indeed, from words let drop by Henry in a conversation with Chapuys, it appears that the emperor, in the embarrassed state of his finances, was unable to borrow money of the bankers at a lower interest than 30 per cent. $\dagger$ His victory at Pavia had spread consternation throughout Europe, and had roused the minor states of Italy to band together in the common peril which menaced them: so that, for a time at least, the master of numerous legions and lord of boundless territories found himself crippled and his efforts brought to a standstill. Wolsey had not miscalculated. The overwhelming preponderance of the emperor would have been a sore offence to him, and, in his judgment, a scrious political mischief. And, shrewd calculator as he was, he was far from being merely a calculator. Charles accused him of being goaded by the spur of disappointment. Because, said the emperor, I did not employ an Italian army, and make him pope by force, he has sworn that I shall repent it. $\downarrow$ And there can be no
* B. iv., part i., 1218.
$\dagger$ Sp., iv. 249.
$\ddagger$ B. iv., part ii., 3844 . 
doubt that a strong under-current of personal feeling sometimes marked with perceptible ripple the course of the cardinal's policy. Far from being cold and bloodless, he had a warm heart as well as fertile brains. And now thenceforward throughont Europe, as though it were a vast chessboard, the two masterly players were disposing their pieces, and resorting to every means of stratagem and chicanery to outwit and checkmate the one the other.

On this occasion the cardinal did not fail to profess his lively interest in the emperor's unexampled good fortune. He dilated on the glowing prospects presented by an opportunity quite unique. Charles might now to his own advantage keep his word. He might requite the services of his ally of England, to whom his pecuniary obligations were considerable. In conjunction with Henry he might invade France, and place his ally, a second Henry V., on the French throne. He might then himself, in due time, wed the Princess Mary, at present a flaxen-haired, precocious child nine years of age-who, indeed, at this very time sent Charles an emerald ring, which he, with smiling gallantry, put upon his little finger.* He might thus himself eventually become 'the lord and owner of all Christendom.' To subdue the dreaded Turk, and have the diadem of universal empire placed on his brows in Constantinople itself, might be the crowning consummation of a destiny transcendently glorious.

Meanwhile Wolsey was not inclined to let slip an occasion for extorting money for his master from his loyal subjects. It was an old feudal custom that pecuniary aid should be accorded by spiritualty and laity when the monarch in person headed an invasion into an enemy's territories. The invasion of France by Henry himself was now matter of discussion, and it was proposed to resort to the ancient financial precedent to obtain the necessary funds. The new name of an 'amicable loan' was

* 'You shall say,' Wolsey directed Tunstal, “ "Her Grace hath devised this token for a better knowledge to be had, when God shall send them grace to be together, whether his Majesty do keep himself as contiuent and chaste, as with God's grace she woll;" whereby ye may say, his Majesty may see that her assured love towards the same hath already such operation in her, that it is also confirmed by jealousy, being one of the greatest signs and tokens of hearty love and cordial affection.'April 3, 1525 (B. iv., part i., 1240). 
given to the contributions to be levied for the emergency. The attempt failed. First the monasteries and spiritualty, and then, after their example, the laity, resisted the demand. It illustrates a characteristic point of difference between the statesmanship of Wolsey, who never much cared to be in touch with the people, and the more sagacious policy in this respect of Henry himself, in whose nature there was a 'popular fibre, that the king expressly enjoined the commissioners to proceed 'doulcely rather than by violence.'* But the experience of monastic independence and stubbornness derived from this abortive attempt was by no means lost upon Henry, although he abandoned his design. It is to Wolsey's credit that he was willing himself to bear the whole brunt of the widespread dissatisfaction, and to leave to the king alone the popularity of withdrawing an obnoxions claim.

It amused Charles to dally for awhile with Wolscy's suggestions; but he was, in fact, as little in earnest as the cardinal. In answer to the matrimonial proposals, he requested that the princess should be sent into Spain, to be there edueated; and whereas he owed Henry 150,000 crowns, he stipulated that 400,000 ducats should be advanced in addition. When such conditions were declined, Charles amnounced his intention of marrying, in eompliance with the wish of his Cortes, Isabella of Portugal, whose dowry was 900,000 erowns. This match gave no little umbrage to Henry. But Isabella, lovely in person, proved no less amiable than she was beautiful. She was daughter of Emanuel, King of Portugal, by the second of two sisters, married in succession, and sister of the reigning John III.

Wolsey drew nearer day by day to France, frustrating the imperial schemes, which aimed at keeping England and France apart. Rome was the centre of diplomacy in that age, and the pope, who had at first supported the emperor, was now changing sides, and, in terror of imperial domination, managed to keep, Wolsey well informed of the course of the French negotiations. 'Thus Louise was successful in her crafty but patriotic endeavours. The estrangement between Henry and Charles was palpably widening. In vain did the Lady

* See Henry's letter, dated May 8, 1525.-B. iv., part i., 1318. 
Margaret strive to preserve intact the former cordial anity. In her solitary steadfastness to the ancient alliance she compared herselt to the one candle whose light still lingers on alone at tenebres.*

After a captivity of a year and twenty-two days, francis regained his personal liberty by the Treaty of Madrid (signed January 14,1526$)$. His two sons were committed to the emperor's custody in their father's place, as hostages for the cession of Burgundy; and Francis himself engaged to marry Leonora, dowager of Portugal, the sister of Charles. Before the captive monarch was set at liberty this marriage was solemnized.

Francis, however, had no sincere intention of carrying into execution all the terms of the Treaty of Madrid, to the fulfilment of some of which his subjects, especially the Burgundians, were irreconcilably opposed. In consenting to the stipulations, which he had at last very reluctantly signed, the released king had counted with confidence upon their determined resistance to the surrender of Burgundy to Charles. The pontiff' and the King of England had both exerted their best interest and made earnest application to procure the release of Francis from captivity, and now, on his deliverance, one of his earliest acts was to enter into an alliance with them, in conjunction with the Venetians and with Sforza, the unfortunate Duke of Milan, who at this very time was shut up in his castle, besieged by the lmperialists. The objects of the compact were declared to be the recovery of the French princes and the reinstatement of sforza, who had much endeared himself to the Milanese, in the quiet possession of his capital and of his territories. This alliance was concluded on May 2s, 1526, at Cognac, and was termed 'Holy,' inasmuch as it was formed under the sanction of his holiness, by whom Henry was nominated (August 15) 'P'rotector of the Italian League.' + It is commonly stated by historians that Clement, using the spiritual resources at his command, absolved Francis from the oath which he had taken; this, however, was after-

* 'La chandelle de tenebres, qui demeure seul en lumiere.'-B. iv., part i., 1079 .

$\dagger$ Clement's Bull nominated Henry 'Protector Fœderis Italici'' decimo octavo Kal. Septembris.'--Rymer, vi., p. 76 ; B. iv., part ii., 2398. 
wards, when the Universal Peace was superseding the treaty, sworn to at Madrid.

Already, before the Holy League had been formed, and before Francis had obtained his liberty, peace had been signed (August 30, 1525) between France and England. Henry asserted that in this peace he had 'provided for the emperor's interests,' and that he intended to keep his good understanding with him 'inviolable.' But at the same time he protested against the marriage of Charles with Portugal as ' contrary to conventions,' and considered that this wedlock, unexpectedly contracted, had entirely cut away the main ground of the former alliance.* The agreement between Francis and Henry was signed at Hampton Court by John .Joachim on August S, and by Francis himself twelve days later.

When Francis was now again at large and in his kingdom, Europe was invited to see and admire the intimate personal friendship, which had sprung up with a growth singularly rapid, between the recent royal adversaries. The one became to the other 'like a very natural loving brother.' Not so long before Henry had denounced Francis to Charles as 'a tyrant who had usurped the patrimony of others, such as the King of England's inheritance in France, his claim to which, he protested, was as clear and good as the claim of Charles to Burgundy. But now all was changed as in a moment. On both sides self-interest, of course, was the chief factor in fastening close the bonds of brotherly affection. To Francis the English connection was necessary, and the succour which in his perplexing difficulties he trusted to derive from English gold he valued at the high worth it deserved.

The portrait of Fraucis as painted generally by historical writers, and even by our own Robertson, is too flattering. 'The king of the gentlemen,' as fashionable Paris styled him,

* Henry's dissatisfaction with the emperor appears in a document of nearly the same date (September, 1525).

'1. The emperor' was bound, June 20, 1522, to pay England 150,000 erowns of the Sun. 'Two years have elapsed, and nothing has been paid.

' 2 . He was bound to pay yearly for the indemnity 133,305 erowns. Three years bave elapsed, and nothing has been paid.

'3. Each prince was bound to invade the common enemy this year in May, 1525. The king has done his part; but the emperor says he cannot afford,' ete.-B. iv., part i., 16i2s, 162!. 
possessed chivalrous courage and fascinating manners; but he was intensely selfish, and thoroughly unprincipled, his money-grasping avidity as uncontrollable as his unabashed licentiousness. He was generous on impulse, deceitful on calculation. Hollow and pretentious, the code of honour professedly his rule, yet too often only professedly, he fell, as a knight, as far below a real knight, such as Bayard, as in religion a hypocrite falls below a saint. Yet, with all his selfishness and gross depravity, Francis could never have treated Charles with the cold and strict rigour wherewith Charles treated him, had their fortunes been reversed and the emperor been the captive and the French king the gaoler. It strengthened the hold of Francis upon his subjects that his nature, alike in its good and bad points, was French to the backbone.

Henry on his side hoped to attain the indulgence of an absorbing passion, through the support and influence of a brother monarch, with whom he thus found it expedient to stand on terms of the closest confidence. The fraternal attachment it was proposed to intensify by the link of affinity. The thought of uniting the Princess Mary to her cousin, James V. of Scotland, was relinquished; and it was proposerl to unite Francis himself-for his marriage with Leonora had not been consummated, and Louise smiled at the disparity of years, saying that she herself had been married at eleven years of age-or, if more desirable, one of his sons, by the tie of matrimony, to ' the pearl of England.'

In contracting this new alliance with France, Wolsey was not at all in sympathy with the national temper. In earlier years a French alliance had been unpopular, when invoked to aid the ambitious plans of Warwick, the king-maker, although it was brought afterwards to pass by Edward IV. on his own behalf. Richard III. had even meditated a war with France, in order to ingratiate himself with his ill-affected people. The national spirit was still the same as ever. Not only was Tyndale strongly Imperialist, but so also were the Kentish clothiers, the merchants connected with the Hanse towns, the trading community generally, and the principal members of the aristocracy. Wolsey, wrote Du Bellay, 'is, I believe, the only 
Englishman who wishes a war with Flanders.' In fact, in the interests of eommeree, it was found necessary soon afterwards to arrange a truce between the allied sovereigns and the Lady Margaret.* Peace between England and Burgundy by time and settled usage had acquired almost the force of an acknowledged state-principle. 'Trade had been well-nigh restricted to. Flanders and Spain. Spanish wil was neeessary for the manufacture of English eloth. But the stirrings of diseontent among the people nothing daunted the haughty cardinal. He even eherished the design of diverting commerce from Flemish to English ports, and of displacing Antwerp by the English mart of Calais. But here his poliey, however deliberate and firm, was contending against a mightier than Charles or than national antipathy, and overlooked the limits assigned by Providence to the best-planned efforts of human genius and power.

And soon a terrible event, as unlooked for, and more extraordinary than even the midnight eapture of Francis at lavia, two years and a quarter before, astounded Christendom as with an earthquake shock, the vibrations of which were felt everywhere. In Italy the star of Charles still maintained its ascendaney. But his troops were of mixed nationality, of low-lived ingredients, and thus very difticult to be kept under control. Their undiseiplined eondition was aggravated by their pay being greatly in arrear. The country around, laid waste and ruined, could not supply provisions for them in quantity at all adequate to their needs. Leaving the Milanese, therefore, the Government of Milan having been committed to Leyva, the hungry soldiers tumed their steps where they might hope to find subsistence. The Venetians, with wary forethought, had safe-guarded their own territories; the Duke d' l'rbino and the forces of the Confederates protected Florence. The road to Rome lay open. Thither, therefore, the imperial troops, hent upon plunder, hurried along, under the guidance rather than the command of Bomrbon. Peseara - after revolving ambitious designs suggested by the artful Norone, and vacillating between loyalty to the emperor and sehemes for self-elevation-was now in his grave. Lannoy had * B. ir., part ii., 39130, 43111. 
even agreed to terms with Clement for a suspension of hostilities, the pontiff engaging to advance sixty thousand erowns for the payment of the troops. By this compact the pontiff's fears had been in some measure lulled to rest. But it only irritated Bourbon to reeeive by a courier an intimation of this agreement; and his movements were even hastened by the unworthy motive of thwarting a rival. The emperor at this erisis was believed to be quite estranged from the pontiff by reason of Clement's proved duplicity and enmity. Long arrears of pay could only be compensated by large license of spoil. Towards Rome, therefore, the imperial soldiers and Bourbon-who to retain some vestige of authority had made himself one with his men in privations and mode of lifehurried on with impatient alacrity.

Various motives swayed the different elements of the tumultuous host: but the different motives all impelled to one and the same hasty achievement. Treacherous Spaniards, reeruited from the renegade Mours, were stimulated to ferocity by the longing for rapine, and the deep detestation of the pope, which filled the breasts of lance-knights, shoeless and penniless, drawn from the robber fastnesses of Germany. These German troops were under the leadership of George Frendsberg, himself--'as Lutheran as may be --who had borne part in the victory of Pavia, had even mortgaged his own eastles and towns for the equipment and maintenance of his soldiers, and believing the papacy to be at the root of the world-wide misery of the times, carried with him a rope, shouting exultingly, "We will hang the pope!' The craving of the hunger-bitten for food, the greed of the less sorely tried fir booty, the fury of zealots for vengeance on the pontiff, were the passions which inflamed the disorganized mass, rather than thirst for blood. As the disorderly ranks pressed on through towns and villages, they swept along with them, as by a natural attraction, numerous rapacious and dissolute Italians.

Soon the hurried array. divided according to its three principal nationalities, stood before Rome itself, which was little prepared for their attack. On the morning of Monday, May 6, 1.527 , under cover of a clense mist, the assanlt, with" searrecly 
any delay, was made on the papal eity. The Imperialists were without magazines and artillery, so that they trusted for success to the rapid effect of a fieree impetuous onset. Bourbon, therefore, perceiving the moment to be eritical, leaper from his horse, and conspicuons by a white vest drawn over his armour, seizing a sealing-ladder with his left hand, with his right beekoned his soldiers to follow him. At this instant he was struck down by a shot from a harquebuse, and fell mortally womnded. His death, instead of disheartening, animated and redoubled the courage and fury of his troops, who quickly effected breaches in the walls, throngh which they poured into the suburbs. At first the pope's guardSwiss mercenaries-fought bravely. But the assailants were not to be diumted or checked; fresh cornbatants joined the attack; the resistance grew feebler, and before long ceased entirely.

Frendsberg had heen left behind sick. Vexed to the soul that his Germans, accustomed to show him dutiful obedience, should, under the sudden strain of circumstanees, have turned insubordinate, he had been prostrated by a stroke of apoplexy. Bourbon had fallen. Thus the troops were their own masters. Their extraordinary snecess had maddened them. Before sunset Rome was at their mercy: and before the morrow's sumset the whole eity was in their hands. Sicenes of avarice, carnage, brutality, ensuel-unexampled and indescribableof which the capture of the same city a year before by l'ompeo Colonna, the rival of Clement-who had only vented his wrath and malice on the pope himself and his ministers-had not afforded the fiaintest forecast. No Huns, Vandals, or Goths, in the struggles of the fifth and sixth centuries harl heen stained ly fonler erines than those now perpetrated by the imperial soldiery. No Turks could have been guilty of baser infamy. It was the least part of the abominations that churches were used as stables, and erucitixes and inages were set up to be marks for shots from harqnebuses. l'illaged. partly devastated, desecrated, the eity, it was said, was 'no longer liome, but Rome's ashes (non urbs, sed bustum urbis).

At the beginning of the tight, Clement, at the high-altar of st. Peter's, was offering up supplications to heaven for victory. 
But when his veterans and Swiss guard gave way, he fled, with. thirteen cardinals, the foreign ambassadors, and other persons of distinction, to the shelter of the Castle of St. Angelo. Here the fugitives resolved to face all extremities rather than subnit to the victors. Their trust was, that the French army of the League would even yet advance to their relief. And D'Urbino did approach the captured city; but only to retreat again, thus tantalizing the imprisoned pontiff with hopes disappointed almost as soon as raised. His army was sufficiently numerous and well appointed to accomplish Clement's deliverance; but, hating the Medici, he preferred to gratify private pique rather than to fulfil the obvious duties of his post. The cup of Clement's sorrow seemed full to the brim, and overflowing, when the counter-party among the Florentines, grasping the opportunity, banished the Medici from their city. This was a crushing blow to family ambition, which Clement felt more acutely than even the sack of Rome.

All Europe was aghast at the appalling intelligence, which spread rapidly through every city and village, from the metropolis of Christendom. Charles himself, although he regarded the sack of Rome and the captivity of Clement as well-deserved, Heaven-sent judgments, and rejoiced in his heart, yet dissembled his satisfaction. With his hands upon his breast he asseverated that what had happened had been done without his commission, against his will, and to his grievous displeasure. He countermanded the festivities prepared to celebrate the birth of his son, the future notorious Philip II., a recent joyous event, and proclaimed that public intercessions should be offered for the pontift"s safety and deliverance.

To Henry and Francis the capture and plunder of Rome and the imprisonment of Clement supplied a convenient pretext, eagerly accepted, for sending a defiance to Charles (January 22, 1528), at Burgos, and formally declaring war,* unless the emperor should be willing to deliver up his holiness and

* 'Clarencieux to Wolsey.-On January 22 (15,28) Guyenne and I made declaration of war against the emperor, as he was sitting in a great hall, in the siege royal, accompanied with all the nobles and gentlemen of his court.'-B. iv., part ii., 3827,3940 . 
the French prinees for a reasonable ransom, and consent to pay his heavy debts to England. The destructive wars kindled by (harles, the perilous progress of the Turk, who had taken Rhodes and Belgrade, together with the misehiefs threatened by new religious seets, were ostentationsly, however inconsistently, thrown in their imperial rival's teeth by the two confederated monarehs.

The rumour quickly gained ground that the heralds had been put in prison by the emperor in his wrath; and Wolsey and the French ambassador were accused of deliberately circulating this idle tale, in order to foment popular indignation. But Clarencieux appeared before Henry and informed him that he and the ambassalor of Francis had 'never been sequestered from liberty, but gently entertained;' and he exhibited 'a chain to the value of seven hundred ducats,' presented to him as a gift by Charles. The chronicler Hall was evidently much pleased to record his king's ' wise saying,' in reply, 'O Lord Jesu, he that I trusted most told me all these things contrary. . . . Now I see perfectly that I am made to believe the thing that was never done.' 


\section{II.-THE KING'S CONSCIENCE.}

THE pontiff, by a commission, signed June 18, 1527, had appointed Wolsey his 'lieutenant and plenipotentiary in France, consequent on the captivity of Clement VII.' A universal peace was to be secured, and meanwhile a perpetual peace was to be arranged between the royal brothers, Henry and Francis. The Princess Mary, it was now proposed, should be married, not to Francis himself, but in due season to Henry, Duke of Orleans, his second son, a child six years old, Mary being eleven years of age. The duke was at present a prisoner in Spain. The allied monarchs engaged to exert joint efforts for the recovery of the princes, and in the event of failure to make war together upon the emperor. Henry, on his part, relinquished his claim to the French throne, and Francis promised to make an annual payment of fifty thousand crowns, together with a tribute of salt, and by convenient instalments to pay two millions of gold crowns besides. By such expedients Wolsey, in the great difficulty of obtaining subsidies or loans-at a time when money was declining in value, and the expenses of the court and the government were steadily on the increase-sought to replenish the king's impoverished coffers. Costly festivities signalized the establishment of amity between the two nations, ${ }^{*}$ and a splendid pageant marked the conclusion of the negotiations.

And in July Wolsey crossed the Channel with a magnificent

* At Hampton Court, 'before the second course, my lord cardinal came in, amongst them all, booted and spurred, all suddenly, and bade them proface. . . My lord took a bowl of gold, which was esteemed of the value of 500 marks, filled with hypocras, whereof there was plenty, and putting off his cap, said, "I drink to the king, my sovereign lord and master, and to the king, your master," ' etc.-_ee Singer's 'Cavendish,' i., pp. 132-135. 
retinue, as Henry's representative. He was to settle all the particulars of the perpetual alliance; and, in pledge of its loyal fulfilment by England, to take the most solemn of all oaths, the sacramental wafer, which was to be divided between him and Francis. He was to concert measures for the safety and release of Clement, and for the regulation of the Church pending his captivity. 'Last, but not least,' he was warily to approach and sound Francis upon a delicate project, which hal for some time occupied Henry's attention, in bringing which to the desired conclusion he trusted to be aided by the sympathy and support of his ally and brother.

This embassy was the zenith of Wolsey's greatness, both as a statesman and as an ecclesiastic. Not only was fulsome adulation lavished upon him by Louise, Francis, and their court, but he was nominated by Clement his vicar during his captivity. There can be no better proof of Wolsey's signal suecess in this embassy, than the altered attitude assumed towards him by Charles. The emperor was induced in the autumn to make overtures to him for a restoration of their former goodwill. Mendoza, the imperial ambassador at London, was directed in a despatch dated September 30, 1527: "You must do everything in your power to bring the cardinal to our service. . . . You will therefore make him in our name the following offers: Firstly, the payment of all arrears on his several pensions, amounting to nine thousand ducats yearly. Secondly, six thousand more dueats until such time as a bishopric or other ecclesiastical endowment of the same revenue becomes vacant in our kingdom. Thirdly, in addition to the above payments, amounting to a considerable sum of money, for we calculate that his pension has not been paid for fire whole years, we shall order the duke who is to have Milin to give him a marquisate in that duchy. . . . The whole which we promise to the said cardinal, if he will only act as he has done on previous occasions, to the advantage and protit of the king his master and our own."*

Wolsey passed from Westminster through London and over London Bridge Wednesday, July :3, with 900 attendants,

* B. iv., part ii, 3464, 3783, 38:39. Shortly afterwards Wolsey was negotiating with Francis and Clement for the deposition of Charles. 
'three in a rank'-Cavendish has exaggerated the number to ' 1,200 '-all in black velvet livery-coats, and most of them decked with chains of gold. The cardinal was preceded by 'two great crosses of silver, two great pillars of silver, the great seal of England,* and his cardinal's hat.' He rode upon a mule 'trapped with crimson velvet upon velvet, his stirrups of copper and gilt,' a spare mule following him 'with like apparel.' Great men were proud to be in his suite; amongst these appeared More, Tunstal and Gardiner.

The cardinal's admonition to the gentlemen of his train is characteristic: 'Let all your entertainment and behaviour be according to all gentleness and humanity, that it may be reported, after your departure from thence, that ye be gentlemen of right good behaviour and of much gentleness, and that ye be men that know your duty to your sovereign lord, and to your master, allowing much your great reverence.' 'The Frenchmen's disposition,' he said pleasantly, 'is such that they will be at the first meeting as familiar with you as though they had been acquainted with you long before, and commune with you in the French tongue as though ye understood every word they spake; therefore, in like manner, be ye as familiar with them again as they with you.' 'Turning to Griffith ap Ryce, Norfolk's brother-in-law-grandson of the Welsh chieftain who had aided Henry VII., who was at that time in favour at court, but was afterwards beheaded (December 4, 15:31)_-" Ryce," quoth he, "speak thou Welsh to him (the Frenchman), and I am well assured that thy Welsh shall be more diffuse (obscure) to him than his French shall be to thee.",

Yet was it a period of no little anxious perplexity to the peace-making cardinal ("le cardinal pacitique"), as Wolsey was now called. Without giving credence to Cavendish's strange idea, that Anne Boleyn and her party had devised this embassy for a personal enemy whom they dreaded, in order

* The great seal was left in Calais, as it could not be taken out of the realm. - Singer's 'Caveudish,' i., p. 93.

Among Palsgrave's subsequent charges occurs: 'We had $£ 100$ a day allowed for our diet, and theu bad we with us all the seals of the realm, so that none act could accordingly pass from the king, till we came home again.'-B. iv., part iii., 5750. 
to remove for awhile his influence, and to undermine it in his absence, there can be no doubt that Henry's uncertain temper and the waywardness of his amorous faney, must have caused questioning and trepidation to his thoughtful minister. As the cardinal in his 'legatine ornaments' knelt 'at a form covered with earpets and cushions' at the ehoir door of Christ Chureh in Canterbury, while the monks and all the ehoir, 'standing in the body of the church,' were, by his direction, chanting the Litany for the eaptive pontiff, 'Sancta Maria, ora pro papa nostra Clemente,' his gentleman usher observed him to 'weep very tenderly.' The desolation of Rome, the humiliation of the papal court, doubtless saddened Wolsey's soul: yet were there dangers, still nearer and more personal, already advancing their threatening shadows to eloud his transient glory.

As early probably as 1524 conscientious scruples in reference to his marriage with Katharine had already begun to harass the king's mind. The premature decease of male ehildren in rapid succession had even aroused Katharine's religious alarm, and had drawn from her the bitter lamentation that her first nuptials had been 'made in blood.' Henry was much disquieted by the mortifying inquiry, who was to be his suceessor? His only male issue was Harry Fitzroy, born 1.519, than whom 'no man,' his tutor* averred, 'had ever better wit.' But he was illegitimate. He was ereated with great ceremony (June 1s, 15.5) Earl of Nottingham and Duke of Richmond, the latter his grandfather's title, with pre-eminence over all other peers, and even over the Princess Mary. No care or cost did the royal father deem excessive to demonstrate his 'eternal affection' for this offspring of an illicit amour with Bessie Blount, one of Katharine's waiting gentlewomen. The evils of a dis-

* John Palsgrare, prebendary of St. Paul's, anthor of the first French Grammar ('Lez le Clarissimaunt de la lange Francois'), published iu England (by Pynson, January, 1524), was his tutor. He recounts : 'The king's grace said nuto me, in the presence of Master Parre and Master Paage, "I deliver," quod be, "unto you three my worldly jewel-you twan to have the guiding of his body, and thou, Palsgrave, to bring him up in virtue and learning." His tutor had to eure him of lisping and of a bad Latin pronunciation, eaught of the priest, who "taught him his matins.' Harry Fitzroy became the bosom friend of Lord Surrey, and married his sister, but died July 22, 1536.-B. iv., part i., 39 ; part iii., 5750,5807 . 
puted succession were written in letters of blood and havoc in the past history of England. As the king pondered the prospects of his throne, with only one legitimate claimant from his own loins, and that one a daughter, the text of Leviticus, "They shall be childless,"* the Divine curse on the incestuous, frowned its warning terrors upon him from God's Book. As yet there had been no instance of a female reigning in England in her own right; and against the succession of a Scotch prince, Margaret's son, 'the very stones in London streets,' it was said, would be constrained to 'cry out.'

Henry mused over the matter day by day, and consulted his favourite school divine, Thomas Aquinas. According to the great Dominican, the laws of Leviticus were moral and eternal, such as no Pope could abrogate. Gradually, as "the secret matter' - as the cause was mysteriously designatedassumed to his deliberations overwhelming importance, the question was communicated to others. And, at first, all that appeared to be sought was the quieting the ruffled conscience of the king, who affected to need no more than sufficient proof that his union with Katharine was Scriptural and valid, so that no obstacle might mar the Princess Mary's unimpeachable title to the throne.

It was under this form that Wolsey, in passing through Kent on his way to Dover, there to embark for Calais, broached the topic to Fisher at Rochester, and then to Warham. Fisher, with unusual caution, reserved his judgment. But Warham was unsuspicious, and no match for the subtle cardinal.

The pretence of endeavouring to satisfy Henry's conscientious, scruples and establish his daughter's legitimacy, was an easy mode of introducing a delicate question; but was in reality hollowness itself. Already Henry had been cited privately (May 17, 1527) to appear before Wolsey, as legate and head of the ecclesiastical courts, to answer for his offence in cohabiting with his brother's widow, as in an ordinary divorce cause. Yet, unabashed, the specious cardinal, at the same time that he was confidentially signifying to Henry his hopes that his 'virtuous desires' would be gratified, wrote

* Lev. xx. 21. See also Lev. xviii. 16. 
careful instructions to Ghinucei and Lee, who were then busily engaged in negotiations with the emperor at Valladolid, to maintain the strictest secrecy, so that Charles might not in any way obtain the faintest idea of the proceeding which the collusive action foreshadowed. There was no foundation whatever, he asserted, for the popular surmises. 'A rumour,' he acknowledged with much regret, 'somehow or another, has sprung up in England that proceedings are being taken for a divorce between the king and queen; but the rumour,' he continued, 'is entirely without foundation;' although, he added, 'not altogether causeless, for there has been some discussion about the papal dispensation, not with any view to a divorce, but to satisfy the French, who have raised the question of illegitimacy in proposing a marriage between the Princess Mary and their sovereign.' Katharine herself, however, was fully aware of the actual state of things; and with ready hereditary art contrived that Francis Philip, a muchtrusted 'sewer,' eluding the anxious watch kept by Wolsey, should make his way to the emperor and deliver to him a letter from his aunt. Charles replied with the amplest promises of protection and assistance.

The Treaty of Amiens-the endeavours of Wolsey being met by the zeal, ability, and tact of Louise, notwithstanding that she was at the time suffering severely from gout-to their mutual satisfaction, placed Henry and Francis in the close relation of 'perpetual allies.' So far everything had succeeded to the cardinal's utmost wish. Yet he had not as yet breathed the king's 'secret matter' into the confidential ear of Francis. 'Nothing now remains,' he wrote to Henry, 'except to disclose your private matter,' which I propose to do 'in so cloudy and dark a sort that he shall not know your utter determination.'

Shortly afterwards the mysterious secret transpired generally, and before long the validity of the papal dispensation was a question submitted to the examination of canonists. Their determination was that marriage with a deceased brother's widow was contrary to Scripture, and that no pope was competent to contravene Scripture. Such was the judgment of Richard Wakfelde, the Oxford Hebraist, on receiving proof of the consummation of the marriage with Arthur. He had pre- 
viously held the opposite opinion. Such was the judgment also of Staftiléo, Dean of the Rota, and of others of high note. The bishops were consulted, under a license from Warham. They all, with the sole exception of Fisher-with whom the fisherman's seal was final, and who had sufficient courage to stand alone-entered a verdict adverse to Katharine.

It has been supposed that Longland, of Lincoln, by Wolsey's patronage Henry's father-confessor, first insinuated the tormenting scruples into the king's mind, and that he was the cardinal's tool in so doing. 'Of whatsoever the king shrove himself, think ye not,' wrote Tyndale, ' that he spake so loud that the cardinal heard it?' But 'Tyndale drew upon common rumour, especially the rumour current with his own religious section, and had no accurate knowledge of transactions passing in England. He hated Wolsey, as did all the Gospellers, and was prone to countenance reports tending to his disparagement. It is probable that Henry himself was the fountain-source of the scruples, and that he won over Longland, and then Wolsey, to share, at least professedly, his private doubts and questionings. Of course, the cardinal was no way reluctant to deal a new blow at Charles through his aunt, and to have a fresh opportunity of binding England and France yet more cordially to one another. That the question of the Princess Mary's illegitimacy had been first mooted by Gabriel Grammont, Bishop of Tarbes, the French Ambassador, was the pretext assigned both to foreigners and to the English public, to the Lord Mayor and Council of London, and the Privy Council.** But this was really an after-thought, a politic device to furnish some apparently solid reason for ventilating a question inherently repulsive and surrounded with difficulties.

Two circumstances contributed to inflame the torturing asperity of the royal scruples. One of these was Katharine's deteriorating health. There were, in Wolsey's words to Grammont at a later period, secret reasons, "which cannot be committed to writing ... certain diseases in the queen defying all remedy, for which, as well as for other causes, the king will never again live with her as his wife.' $\dagger$

In addition to such an incentive to estrangement, Henry's

* B. iv., part ii., 4942.

† B. iv., part ii., 3644 . 
eyes had been blindly faseinated by another waiting gentlewoman of Katharine, a piquant contrast both to her mistress and to Bessie Blount. 'This was Anne, the second daughter of Sir Thomas Boleyn, who ere long became the pivot on which events turned of the deepest moment to England and the world.

Holbein's portrait of Anne represents her with a long nose, slightly aquiline, and a pale, oval face. But as regards her beauty, different accounts remain to us from her contemporaries. The Venetian ambassador described her as of middling stature, swarthy complexion, long neck, wide mouth, bosom not much raised.* It is clear that her ehief bodily attractions were brilliant eyes and hair beautiful and luxuriant as Berenice's. Brewer has eompared her to Tennyson's Irish Isolt, tracing back to her Celtic blood, through the Ormonds,

\section{'The black-blue Irish hair and Irish eyes.'}

Anne's flowing locks, however-whatever Brewer, on the authority of Sanders, may say to the contrary-were really auburn, the tincture of her Saxon pedigree through the Howards. Froude notes her 'heavy lips' and 'massive chin.' The little finger of her left hand was disfigured by ' a boss and second nail,' a slight deformity dexterousiy hidden by hanging sleeves. The turn of her glossy thruat was exquisite, but her long neck was marked by a large mole under her high ruff. Aceording to Wyat, her beauty, "not so whitely as clear and fresh, above all we may esteem,' outshone such insignificant blots. Sprightly and elever, quick at repartee, vigorous by temperament, she was mistress of many aceomplishmentssang well, played with skill on flute and rebee, excelled in dancing and in the games in fashion at Court.

The Boleyns were of Norman extraction, and in less remote times had been engaged in trade. Anne's father had married as his first wite the Lady Elizabeth Howard, Norfolk's sister, Anne's mother. He retained in middle age, after the elouds had dropped plenty, the habits of parsimony contracted in his earlier straits. Anne had enjoyed the advantage of friendly association with persons distinguished by mental gifts. Lord

$$
\text { * Ven., iv., } 824 \text {. }
$$


Surrey (Henry Howard), the poet, was her cousin-german. Thomas Sackville was the son of a cousin. Her own brother George, the pet of the family, aspired to poetical fame.* George Wyat has recounted how another poet, Sir Thomas (Wiate), his grandfather, admired her grace and beauty. In that age some chosen lady was commonly the suggestive basis of the perfect ideal which served to kindle the poetical flame. Among greater poets, such Laura had been to Petrarch, and Beatrice to Dante. And such was Anne to Sir Thomas Wyat, himself too, like the other men of talent of the period, a favourer of the New Learning.

She was born in 1507 , $†$ and when very young was sent into France, ${ }_{+}^{+}$and made one of Queen Claude's women. In 1522 she returned home, and obtained a post in the wardrobe. At this time France and England were at variance; but it was a further reason for her return that Wolsey was desirous of wedding her to her cousin James Butler, son of Ormond, in order to strengthen the loyal party in the Irish pale, and to reconcile the English and Irish branches of the family, between whom there was a bitter dispute from rival claims to the inheritance of the last Earl of Wiltshire, Anne's grandfather. Ormond himself approved the match; and to accomplish it, Wolsey compelled Henry Percy, Northumberland's son, who had been brought up in the Cardinal's house, and had entered into some kind of matrimonial understanding with Anne, to cease from toying with her, and to wed Shrewsbury's daughter, the Lady Mary Talbot, to whom he had been affianced from boyhood. When Wolsey found his admonition to Percy to forbear entangling himself with 'a foolish girl yonder in the court' but little heeded, he sent for

* See G. Wyat's Memoir in Singer's 'Cavendish,' ii., p. 18:2 ; Tottel's 'Miscellany ;' Harrington's 'Nugæ Antiquæ;' Nott's 'Surrey and Wyatt' (1815).

$\dagger$ The date given in Camden's 'Elizabeth,' p. 2, note. Hepworth Dixon says that Anne was born 1501; but this date would make her Crinmer's pupil at twenty-eight years of age.-'Two Queens,' iii., p. 389, notes.

Ғ Not with Mary Tudor, as Miss Strickland says. It was her elder and less masculine sister, $M$. Boleyn, who accompanied the French Queen to France, and afterwards was fille dhomeur to Margaret of Savoy.-See B. i., Preface, p. lxv. 
Northumberland, who rated his son with much severity, and even threatened to disinherit him.

But before this Henry must have observed Anne in the masques and revels common in the merry England of that age, especially at Court. The wife of Suffolk, the French queen, or Queen Blanche, as she was now called, admitted Anne to the very select eircle of ladies, with whom she was wont to converse freely and familiarly in French. 'The king's fancy for Anne was probably heightened through Percy's attentions, under the goad of jealousy, to keener passion. At length, as Cavendish narrates, Henry 'could hide no longer his secret affection, but revealed his secret intendment unto my lord cardinal in that behalf.'

Conversations with Anne stirred the king's tormenting scruples to yet keener activity. Already in 1525 his amorous passion must have gained the ascendant; for not only was Harry Fitzroy that year created Duke of Richmond and Somerset; but on the very same day (June 1S), Sir Thomas Boleyn also was created Viscount Rochford-the former the first, the latter the last of seven creations.t The connecting link between the two in the royal mind must have been the anxious resolve to establish the succession. To the same period must be referred Henry's walk and talk in the most friendly guise with Sir Thomas More in the garden of Chelsea Manor. The king would fain have enlisted on his side in his contemplated legal suit the most estimable of men, as well as the ablest lawyer of his time. More, with eminent sagacity and penetration eluded the snare.

It was with little alarm at first that the cardinal noticed his sovereign's infatuated partiality for Anne. The affair will end, thought he, as the previous amorous fancy for Bessie Blount ended. Anne, however, was of a different mould. There is a letter of Henry to her, without date, like the rest of his love-letters, but which must have been written early in the courtship, wherein he protests: 'If it please you to do the oftice of a true loyal mistress, and give yourself body and

* Hall says (p. 703) that these creations were made "Sondaie, 18 June.'

+ B. iv., part iii., (6083, 6085. Viscount Rochford was created Earl of Wiltshire in England and Earl of Ormond in Ireland, December, 1529. 
heart to me, who have becn and mean to be your loyal servant, I promise you not only the name, but that I shall make you my sole mistress, remove all others from my affection and serve you only.' This amorous correspondence throws much light on individual character, as well as on a courtship fraught with vital consequences to the English people. Anne's letters are missing; Henry's were taken from Anne's cabinet whilst the matrimonial suit was in process, and conveyed to Rome by Ridolpho, Campeggio's second son, born by a marriage contracted before the cardinal took holy orders.*

It was part of Wolsey's deliberate policy that his sovereign should choose a wife from the French royal family. He would have had him marry Marguerite, the sister of Francis, widow of the Duke of Alençon, who had died 15.5 in Passion W tek. On her marriage, January, 1526, to the King of Navarre, he would have approved his master's union with Renée, sister of Claude, and daughter of Louis XII., not a handsome woman, but clever and sprightly. When he observed to how serious a point Anne's powerful fascination was tending, he threw himself at his master's feet, and persisted for a long time in entreating him to relinquish his fond intention of marrying her.

But to implore a nature such as Henry's hour after hour was fruitless labour. The king was blinded by an absorbing passion. The able minister, however, must be conciliated, and be rendered helpful to the royal purpose. Anne accordingly bent all her skill to win over the cardinal; and inasmuch as Henry's resolution was unalterably fixed, her solicitous efforts appeared to attain, gradually, success. For Wolsey's attachment to his master knew no bounds. One of his despatches, just before he quitted France, testified with sincere fervour: "You will always find me a true and obedient servant, delighting in no earthly thing so much as to accomplish all your commandments. I propose to leave,' he added, 'on Monday or Tuesday, journeying with such diligence as $\mathrm{my}$ old and cracked body may endure't When at last the sagacious minister's endeavours seemed to be seconding the sovereign's vehement caprice, Anne wrote to the cardinal,

* Henry's love-letters will be found B. iv., part ii., 3218, etc.

$\dagger$ Dated Compiègne, September 13 (1527).-B. iv., jart ii., 342:3. 
urged thereto by her royal lover, who himself added a postscript: "The great pains you take for me both day and night are never likely to be reeompensed but alonely in loving you, next unto the king's grace, above all creatures living, as my deeds shall manifest.'

Neanwhile Clement was languishing in the sheltering retreat of St. Angelo. Here-expeetirig at one time to be attacked by the plague, which was raging around him, so that he made provision for the election of his successor, trembling under the strict watch of imperial sentinels, guarded, too, from escape or release by hostile lance-knights, compelled to sustain an enfeebled existence on asses' flesh, indebted for his daily salad to the compassion of an aged beggar-woman-the fugitive pontiff remained in captivity for no less a term than seven months.

During this period Henry's demand for a divoree was communicated to him. Clement expressed all willingness to comply with the King of England's request. Nor was the demand unexampled. Not only in the twelfth century had Louis VII. (the Young) of France, by the advice of St. Bernard, and on the authority of a council, divorced (on the ground of consanguinity) his wite Eleanor, who then wedded Henry of Normandy, afterwards Henry II. of England, but, within quite recent memory, Louis XII. had been permitted by Christ's vicar to put away his wife, daughter to Louis XI., to whom he had been united twenty-two years, simply for the sake of marrying his predecessor's widow, for the politic purpose of retaining Britany as an appanage of the French crown. The case of Henry VIII. of England was far stronger. He maintained that his wedlock with Katharine - on the ground of relationship in the first degree, and plain Scriptural prohibition, such as no human authority could countervailhad never been really valid; and he had the further support of a state reason of prime foree, the national requirement of a legitimate male successor to the throne.

The only peeuliarities of the English case were the dispensation of Julius, and the more stubborn faet that the woman to be divoreed was aunt to the emperor. The pontiff' was the prisoner of Charles, and it soon appeared that the emperor 
was determined to make the most of his commanding position. Before the pontiff, therefore, was allowed to quit his asylum and prison-house, he received a visit from a Spanish emissary of Charles, Francis Quiñones, general of the Cordeliers, whom, to gratify the emperor, Clement named Cardinal Santa Croce, and who was subsequently generally known and esteemed as Cardinal Angel. Preliminary to liberation, stipulations were requisite; and amongst these a solemn promise was exacted to the emperor that nothing prejudicial to his aunt should ever be sanctioned by his pontifical warrant.

Then, before the arranged time had quite arrived, in the dusk of evening, on December 9th, a tall man, apparently a merchant, dressed in a blouse, with a long beard, a slouched and tattered hat drawn down over his eyes, a basket on his left arm, an empty sack at his back, crossed the garden of St. Peter's, passed through a private gate, of which the key had been secretly procured, and monnted a chaise which was in waiting outside. With only a peasant as guide, the disguised fugitive then struck through the forest in the midnight, and, pursuing the mountain track, reached the dilapidated town of Orbieto by the morning light. Here, lodged in the comfortless, illfurnished bishop's palace, his holiness, a few days later, was waited upon by Knight, Henry's confidential envoy.

Henry was now striving to outwit the cardinal, who at this time was absent on his French embassy. The stratagem, no doubt, had Anne's full approval. Henry directed Knight, who was an infirm, genial old man, to obtain two Bulls, one for Wolsey's eye, in terms devised by him; the other to be kept secret, for the eye of the king alone. By the secret dispensation Henry was to be empowered to proceed to second nuptials at once, before his first marriage had been dissolved.* The King of England had sent to Clement in his distress a gift of

* Knight to Henry VIII., Compiègne, September 13 (1527) : 'Have received your letter by Christ. More concerning your secret affair, which is to me alone committed. . . . If the dispensation may be obtained constante matrinonio, of which I doubt, I shall soon obtain it ; if only soluto matrimonio, less diligence will be required.'

Knight wrote, after complete failure, April 21,1528 : ' It pierceth $\mathrm{my}$ stomach, that any charge committed to me should not be performed according to your royal pleasure, as happened at my last voyage,' etc.B. iv., part ii., 3422,4185 . See 3749,3751 likewise. 
twenty-five thousand ducats, and now hoped for a weleome token of cordial gratitude. But the king's request by his confidential envoy eertainly does not exhibit his serupulous conscientiousness to much advantage. It is probable, however, that the scheme of the secret dispensation was abandoned promptly when discountenaneed by the pontiff. The dispensation and commission, which Clement seemed disposed to approve generally, were eommitted by him to Lorenzo Pueci, Cardinal St. Quatuor (Santi Quattro), to be 'reformed.' Knight offered the eardinal two thousand crowns, which, however, he could not prevail upon him to accept, for his valuable services. Elate with faneied success, Knight then 'sped' the amended documents to Henry himself, by Gambara. But, on examination, it was found that St. Quatuor's revision had been only too effectual. The documents were of no use for the desired purpose.

On his return from France, Wolsey resumed the management of the intricate negotiations. The eardinal employed as his eustomary diplomatic tools, besides speeial envoys, Gregory Casale, a lawyer, of Florence, but a Venetian by birth, one of several brothers, three of whom were in Henry's pay; (xhinueci, Bishop of Worcester, imperial ambassador; and the prothonotary, Gambara.

The king's ease, as stated by Wolsey in a despatch dated December 5, 1527, was as follows: 'The king,' wrote the eardinal to Casale, 'has made diligent inquiry whether the dispensation granted by Pope Julius to himself and the queen as his brother's wife, is valid and sufficient; and he is told it is not. The Bull of dispensation is founded on certain false suggestions; as that his Majesty desired the marriage for the sake of a good understanding between Henry VII. and Ferdinand and Isabella; whereas there was no suspicion of any misunderstanding between them. And, secondly, he never assented or knew anything of this Bull, nor wished for the marriage. (On these grounds it is judged inefficacious. Then, when the king reached the age of fourteen, the eontract was revoked, and Henry VII. objected to the marriage. To this the king attributes the death of all his male children, and cheads the heavy wrath of God if he persists. Notwithstand- 
ing his scruples of conscience, he has resolved to wait for the julgment of the Holy See, trusting that, out of consideration to his services on behalf of the Church, the Pope will not decline to remove these scruples, and discover a method whereby the king may take another wife, and, God willing, have male children.'*

Casale was instructed to change his dress, and as though he were acting in some other person's cause, to obtain a secret interview with Clement. He was then to urge the pope without delay, and without disclosing his purpose to anyone, to issue a special commission directed to Wolsey, granting him a faculty to summon whom he pleased in order to inquire into the validity of the dispensation. A commission, so arranged as not to require transcription or occasion any delay if the pope's officials must take a copy of it, was enclosed for the papal signature and seal.

This commission, slightly abridged from the Latin, ran as follows: 'Whereas, eighteen years ago, our dearest son in Christ, Henry VIII., King of England, etc., was induced, by the persuasion of those about him and a pretended apostolic dispensation, to contract marriage with Katharine, his brother's widow; and whereas it has been found, upon further examination, that the said dispensation was granted upon false pretences, and is faulty and surreptitious-that thereby the king's conscience is troubled; and that in full confidence of our plenary power, as supreme ruler here on earth, he has required, etc. . . . .

'In consideration of the premises, we appoint you, our dear' son, the Cardinal of York-of whose virtues, love of justice and equity we are well assured-to exercise our authority in your own person for the trial of this cause. We also appoint you .... as assessor; enacting that the decision of either of you shall be valid in the absence of the other. You are to proceed surnmarily and de pleno, without the publicity or formality of judicial procecdings, and inquire into the validity of the said dispensation. And if you jointly or severally are satisfied of its invalidity, you shall pronounce the marriage between Henry and Katharine to be null and void, allowing

$$
\text { * See B. iv., part ii., } 36+1,4251 .
$$


the parties to separate, and contract marriage de novo, all appeal or challenge set aside. Also by this, our authority, we empower you to overrule all canonical defects or objections, and declare the issue of the first, as well as of the second marriage, to be legitimate if you think fit. And whatever is done by you in this cause, judicially or extra-judicially, we ratify and confirm in the fullest manner without revocation.**

A clause was unobtrusively slipped in: 'I send you a dispensation also, drawn out in due form of a brief, to be expedited by his holiness aftixing his signature and seal.' The dispensation was to this effect:

'As the steward and dispenser of the Lord's household is bound to listen to the prayers of the faithful, especially to one who, like Henry VIII., has distinguished himself in defence of the Church, and by his accession to the erown of England has reconciled the conflicting elaims of Yorkist and Lancastrian, ete. We, in order to take away all occasion from evil-doers, do hereby, in the plenitude of our power, and exercising supreme and absolute authority, suspend lace vice, all canons forbidding marriage in the fourth degree; also all canons de impedimento publicu lonestatis, preventing marriage in consequence of espousals elandestinely contracted, and vitiating such contract. Further we suspend hereby all canons relating to any precontracts clandestinely made, but not consummated, but tending to prevent or invalidate a subsequent marriage; also all canons touching any impediment caused by "ffinity, "rising from any illicit connection, in any degree whatwoever even in the first, so far as the marriage to be contracted by you, the petitioner, can be objected to, or anywise be impugned by the same,' ete.

From such terms it is plain, beyond controversy, that the contemplated royal wedlock with Anne was distinetly before the cardinal's mind. 'The commission was for the dissolution of the marriage with Katharine; the dispensation was to sweep away whatever impediments might exist to the marriage with Anne; and to remove at the same time every possible

* B. iv., part ii., 3641, 3643, 3694; B. iv., Introduction, pp. ccexxiv., ecexxy.

† B. iv., part ii., 3t86 ; B. iv., Introd., pp. ccexxvii.-ce $x$ xix. 
objection to the perfect legitimacy of any child that might be born from such new marriage. Around its cautious safeguards a mystery certainly seemed to hang in murky glimmer, which, if rightly interpreted by Henry's own seeming tacit admission in a private conversation,* must effectually discredit the royal pretensions to extreme sensitiveness of conscience-the 'rack and torments' under which Henry professed to have smarted so many years. That in his confessions to Longland the king 'spake so loud' that the cardinal overheard him, as Tyndale declared, may after all have been in some sort true.

It was the last day in December, 1.527 , when the pope signed the documents which St. Quatior had 'reformed,' and which Knight transmitted to England with absolutely abortive result, as has been already mentioned. As Clement delivered the documents to Henry's envoy, he broke out into fervid protestations, that he was 'now in the power of the dogs.' sighs and tear's almost choked his utterance. And no doubt his position was hazardous and perplexing in the extreme. For although he was at the emperor's mercy and in abject terror of his will, he was nevertheless unwilling to offend irretrievably two such powerful sovereigns as Henry and Francis, who had now assembled a large army in Italy under Lautrec, and were just on the point of declaring war conjointly against Charles.

Application was made by Casale to Clement, January 12,

* sir George Throsmorten to Henry VIII. The letter is in the Record Office. 'Sir Thomas Dingley said : "I perceive his grace's conscience is troubled, for that he hath married his brother's wife, and he thinketh (rod is not pleased therewith." And I said to him that I told your grace I feared if ye did marry Queen Aune, your conscience would be more troubled at the length, for that it is thought ye have meddled with both the mother and the sister. And his grace said, "Never with the mother." And my lord privy seal, standing by, said, "Nor with the sister either." etc.'

Brewer observes that Throgmorten 'was by no means the only person about the court who believed a report, which the terms of this dispensation seem so strongly to confirm.'

Throgmorten, however, was a partisan of Rome; a witness against Latimer, ete. He signed his name 'George Throlimartun.'-B. vi., 12;;). At Anne's coronation ' $\mathrm{Sir}$ Geo. Frogmerton' is amoug the 'servitors from the dresers.'-B. vi., 5i2. He was not held in high esteem for straightforwardness. - B. vi., 12↔.

The suspicions which were afloat do little credit to the Boleyns, and less to Henry. Throgmorten's letter is characteristic of the age. 
1528 , to send a legate into Fngland to try the cause. In consideration of Katharine's not unreasonable antipathy to IVolsey as judge, it was suggested that Campeggio, Trani, or Farnese should be commissioned to determine the suit. Wolsey himself was reluetant to bear too burdensome a weight of responsibility. Clement demurred at first. The pontiff would have chosen a different course. He would have preferred that Wolsey alone should be entrusted with the decision : that the king-than whom, he said, no doctor could better resolve the question-should, without more ado, marry again; should then maintain his new marriage by legal trial; and in the event of difficulties arising, should only, in the last resort, apply to Christ's vicar for a legate. By such a course Ciement thought that responsibility would be shifted from the pontifical shoulders, and that the dreaded ruggedness of imperial displeasure would be at least somewhat smoothed. But the plan failed to content Henry, who insisted upon the necessity of a secure foundation in a case involving the succession to the throne.

To bring the troublesome negotiations at last to a conelusion, the eardinal sent to Rome, February, 1.52 8 , his own secretary, Stephen Gardiner, commended by Erasmus for his skill in making a salad, but possessed also of other more valuable aceomplishments. Wolsey designated him 'the half of myself (mei dimidium).' Edward Fox was joined to ('ardiner in the embassy; but to Wolsey's able secretary was entrusted the leading part in the conferences. In a very earnest letter Henry himself implored ('lement to vouchsafe him a favour, on which depended the continuation of his line,' the peace of his kingdom, and the safety of his soul. Wolsey also, in order to dispossess the pontitt of the notion which hat gained eirculation, that the king's proceedings were frompted by 'vain affection,' took occasion, in a remarkable letter, to expatiate upon Aune's singular merits. "The approved excellent virtuons qualities of the said gentlewoman, the purity of her life, her constant virginity, her maidenly and womanly pudieity, her soberness, chasteness, meekness, humility, wisclom, descent right noble and high, through regal blood, education in all good and landable qualities and 
manners, apparent aptness to procreation of children, with her other infinite good qualities, more to be regarded and esteemed than the only progeny, be the grounds on which the king's desire is founded, which Wolsey regards as honest and necessary.'米

Fox and Gardiner reached Orbieto Saturday, March 20, after encountering very foul weather. They had to ford their way on horseback through a river, the water coming up almost to their girdles. Clement they found but poorly lodged, 'hunger, scarcity, and ill air' keeping him almost as much a prisoner as he had been in 'Castel Angel.' A brief delay was unavoidable, whilst new garments were 'at the making.' But they were freshly equipped, and an audience, Monday, March 2.2, was granted to them by the pontiff in his bedchamber. Gardiner pointed out the defects in the documents 'reformed' by St. Quatuor, which in their present shape Wolsey considered 'as good as none at all.' Yet Clement, he said, must have granted them, supposing them to be 'sufficient." The pope was therefore requested to pass the commission and dispensation which the envoys had brought with them, according to the forms which have been already given in the above pages in their main substance.

Clement answered that Italy was not as yet pacified; and until that desirable event, it was indispensable that he should dissemble. The next day the envoys presented the king's book upon his 'great cause.' Clement stood up, and began reading it, and expressed aloud his high eulogium. Many conferences followed; for nine days Gardiner and Fox were closeted with his holiness, three or four hours every day. At the end of this time, Lord Rochford's priest-probably John Barlow-was sent home with the welcome tidings of the goodwill entertained by the pontift. The discussions continued. With forcible plainness Gardiner did not hesitate to warn the pope that in the event of his stubborn obduracy the alienation of England from the holy see must be deemed inevitable. Clement could only sigh: wipe his eyes; throw about his arms; wind and unwind his handkerchief; or, to cool his rising petulance, vent a witticism, as when he complained

* B. iv., part ii., 3913. 
that the law declared that the pontiff has all truth locked up in the cabinet of his breast; but, for his own part, he must confess that the Almighty had never given to him the key to open it. The 'commission decretal' no eloquence of Gardiner, no epistolary argumentation on Wolsey's part, could prevail upon Clement to sign. The pope would only consent to pass a 'general commission,' whereby the decision of legates required to be ratified, in order to take effect, by papal confirmation. It was to no purpose that Wolsey repeated again and again the assurance that the decretal should remain a profound secret, and be shown to no one; and that the cardinal only urged the concession so strongly in order to increase his influence with the king, and that for the sake of the stability of the holy see. The dispensation Clement passed, together with the general commission, "without the alteration of a word.'*

The tedious negotiations at last concluded, Fox returned to London; Gardiner remained to conduct into England Campeggio, pronounced by him "the only cardinal here fit for this legation,' and whom ('lement had at length consented, however sorely against the grain, to nominate as Wolsey's colleague in the fortheoming trial. By his dexterity and address Gardiner had won unusual eredit; and by the king, in the exuberance of joy, he was styled ' the treasure and pearl of the realm.' And thus on his return he was promoted to the post of the king's 'chief secretary.' Clement, for his dilatory propensities, Gardiner designated 'Cunctator Maximus'; but with results, he added, the very opposite to the success of 'Labius Maximus.' Yet, out-argued by the English enroy's acuteness and ready wit, never for a moment had Clement, however hard pressed, uttered an indiscreet syllable, or failed to kecp his temper in due subjection. Discomfited in argument, he remained, after all, master of the situation. What the eventual outeome of the papal embarrassments would be Gardiner foretold correctly. He foresaw clearly that Clement, indignant with the Venetians, who had oceupied Cervia and Ravenna, in order to prevent the Imperialists from seizing

* As authorities, see B. iv., part ii., 4.246, 4.249, 4.51, 4.290, more especially ; and for particulars omitted, for brerity's sake, 4119,4167 . 
them, but delayed to restore them to the Roman see-dispirited, moreover, by the lingering movements of Lautrecwould recede erelong altogether from the Italian League, and place himself entirely under the dictation of the emperor.

Meanwhile Henry's relationship to Anne had been growing more and more familiar and intimate. In the earlier stages of the courtship he had visited her at Hever (astle, her father's seat in Kent. Local tradition relates that on the brow of the hill overlooking the castle the king would wind his horn, and then watch for the sign of welcome which Anne was wont to display to her royal admirer from the tower.

But in December, $152 \mathrm{~s}$, an absolute separation was accomplished by him from Katharine-a mense et thoro. Then Anne was provided with apartments, furnished with reckless expenditure, in a wing of the palace at Greenwich. Here marked deference and court were paid to her, as though she were already queen.* Katharine pined, deserted in the other wing of the same building. It was similar evidence of the engrossing eagerness wherewith Henry's heart was set upon the hope of male succession, that Harry Fitzroy was surrounded by the infatuated father with a brilliant retinue, and allowed a splendid annual income; whilst the Princess Mary lived in comparative obscurity and porerty, with but little of the courtly observance befitting her rank.

What Anne's real character was has always been a point on which the judgment of history has been divided. Characterized by a foreign ambassador, together with her father, as 'more Lutheran than Luther,' she drew around her whilst she lived the good opinion and kind wishes of the Protestants, and was disliked with equal fervour by the partisans of Rome. Cranmer with all sincerity could write of her, 'I never had better opinion in woman than I had in her.' To Chapuys, on the other hand, 'the wench (manceba), the conculine,' was the incarnation of all that is vile; for boldness a lioness, yet a stealthy poisoner, who could attempt Fisher's life, and would make away, if she could, with Katharine and the princess. Her memory has been pursued to our own times with similar blame and commendation. 
It may be conceded to her opponents that she was selfindulgent, an epicure, delighting in fish, 'carps, shrimps or other,' from Wolsey's tisheries at Norham, or 'a morsel of tumny' from the king's table. Similar obloquy tracks the memory of Charles $\mathrm{V}$; nor is the blame peculiar to Anne among her own sex, or decisive as to her general merits. A letter from the bearer on one oceasion of a delicate dish from the king's table has come down to us.* It must also be coneeded that she sometimes tolerated in her presence conversation not so mexceptionably decent as it should have been: and that, beyond this, she sometimes demeaned herself so far as to take part in it. But here some allowance must be granted to her equivoeal position, which must have dragged her down in her own estimation as well as in the estimation of those about her. Her own education likewise, and the unrefined notions of the age, must not be excluded from the account. There can be no doubt that her sojourn in France, where Francis and Marguerite were the chief favourers of the Reformation-as she herself afterwards was in England-had not franed her manners to severe decorum. Even Marguerite, praised as she was by Tyndale for her 'knowledge of Christ,' nevertheless affected in her writings an imitation of the indecencies of Boccaceio, as well as of his better qualities. And as Marguerite wrote, so Anne behared-after a fashion accepted in a very coarse age, when, according to Mrs. Amadas, there were only three 'good married women' in England: (Queen Katharine, the Duchess of Norfolk and herself. $†$ In England little restraint controlled in that age the intercourse of the sexes, memories of antique chivalry and Arthurian romance lingering on in the upper ranks.

'To such considerations, to which their fair weight nust be

* She invited the bearer, Thomas Hennege, of the household, first of Wolsey, then of the king, brother of Arehdeacon Hennege, to share her good eheer.-13. iv., part ii., 4005.

$\dagger$ B. vi., $12: 3$. Mrs. Amadas was a spanish lady. She prophesied: "the realm shall be conquered by the scots and my comtrymen'- 'the good emperor will deliver all good wives when he eomes,' etc. She was probably the wife of Robert Amadas, citizen of London, and goldsmith, and mister of the king's jewel holse at Eltham.

B. iv., part i., 1907 (2) ; v. 179!). 
allowed, it must be added in simple justice that Anne was only just emerging from girlhood into womanhood when the royal fancy was first smitten with her lustrous eyes and graceful manners. Her too close familiarity with a lover who was at the very time a married man has subjected her to welldeserved reprehension. But even here it must be borne in mind that she had heard again and again from those whom she was most bound to hold in high respect that the marriage of Henry and Katharine had never been a real marriage at all. Her intimate companionship with the king, notwithstanding general censure, seemed so litt'e blamable to her pious tutor Cranmer, that on one occasion he himself communicated the intelligence to her father: "The king and my Lady Anne rode yesterday to Windsor, and this night they be looked for again at Hampton Court. God be their guide?" The indignation of lookers-on may be better conceived than described, when on one occasion-as, at least, the imperial ambassador informed Charles-Henry rode out of IVindsor with Anne on a pillion behind him.

That she was ambitious and imperious admits of little question. It appears that she was real and genuine in her professions, vigorously outspoken in word and epistle,* liberal to profusion in her charities-a profusion stimulated doubtless by party and personal motives-warm in her sympathies, strong and bitter in her resentments. A character so mixed has been foully blackened by the hideous chargest-the ' unutterable turpitudes' - which finally bared her neck to the nimble swordswoop of the muftled St. Omer headsman. But here, whatever Lingard, or Froude, or Brewer, or others may opine, the mind reverts with far fuller satisfaction to the sound judgment and impartial acumen of Mackintosh. + It is incontestable that the charges brought against her were unsubstantiated by legal proof; while, at the same time, the motives which actuated Henry, and those who had a hand and interest in her destruction - anxiety for male issue,

* See B. $\nabla_{.}, 12$.

† These appear baldly and grossly, according to the rumours current with the Imperialists, in the Sprenish Chronicle, ed. by Martin A. Sharp Hume, pp. $54-71$.

$\ddagger+$ Mackintosh's 'History of England,' ii., pp. 194-205. 
personal and party ambition and lust-are on the very surface and only too palpable. Paul Friedmann, in his careful biography, aecuits her of the accusations which cost her life, at the same time that he expresses a mean opinion of her character. And it must be allowed that for the calumnies heaped against her, Anne's own demeanour - too often frivolous and light-the indecorous laughter and unwomanly jests which afterwards marked and marred the behaviour of her daughter Elizabeth-prepared in prejudiced quarters a too facile credence.

But what is to be thought of Henry himself? In his case the voice of calm reflection ought to be as clear and decided as the facts are indisputable. Faithless and cruel towards Katharine, it ought not to be passed over in silence that he was scarcely less eruel towards Anne. Twice as old as she was at the time of their first meeting, gifted by nature with superior mental endowments, which culture had strengthened, he abused his influence-it may almost be said his authority -to her worldly advancement, but her real degradation. Treading in the steps of his grandfather, Edward IV., he had so completely established the new despotism, that More, in his ' Utopia, deemed it right to enter a distinet protest against the notion that 'the ling can do no wrong, however much he may wish to do it; that not only the property, but the persons of his subjects are his own.'

What is peeuliarly characteristic of Henry is the, if possible, more than infatuation of his self-deception. He chose as his especial intimates the worst profligates of his court, reprobates such as Compton and Bryan; he engaged with them in pastimes by day and at the gaming-table by night.* And yet he heard Mass three or, if it were not the hunting-season, five times a day. He would hear Mass with solemn ceremony on Sunday, and then sit up the Sunday night until three or four o'clock on the Monday morning playing at cards. Yet, none the less, with flagrant inconsistency, he could lament to

* Ilis 'privy purse' expenses for .January, 1530, record: 'Lost by the king to Domyngo at game, ifin). To the Duke of suffolk, for money borrowed by the king to play, f100 in angels- 11210 s., etc. B. v., 1799. He gave Anne money to play with. 'The Puritans' hour had not come yet. 
Erasmus 'the prostration of good manners,' that 'all things are degenerate,' and could declare, as an object very near to his heart, that he had felt for some years the desire to 'restore the faith and religion of Christ.'* Becoming more and more false as he threaded his tortuous way through the maze of his divorce cause, he had nevertheless rebukes of seeming moral grandeur for far less gross delinquents than himself. It is remarkable that piety was even an essential of his manly and kingly ideal. 'O most pious king!' such was the style of Wolsey's address, when he would fain conciliate his alienated sovereign. Henry assumed the airs, not only of a profound theologian, but of exemplary personal piety; and this, too, after he had become the unresisting slave of the vilest passions that transform a man into a monster.

The objective system of the papal Church tended to render self-deception so astounding, not impossible. Henry was essentiaily a Romanist, and always remained such as far as was compatible with that inmost native despotism which outward circumstances pampered, and gradually drew forth into thorough development. In contrast to his umrestrained selfindulgence, how elear and keen his moral sense in regard to the duties incumbent on others! 'The magnificence and inordinate ambition,' he declared, 'of the pope and cardinals have been the cause of wars, discords, and heresies.' 'Had Luther,' he asserted, 'only inveighed against the vices, abuses, and scandalous lives of the clergy, instead of attacking the sacraments of the Chureh and other Divine institutions, I should myself have taken pen in hand to write, not against him, but in his defence.' $\dagger$ 'That Henry was cradled in Romish superstition, and grew old and unwieldy in the exereise of an iron despotism, may be pleaded, at least, as some explanation, and even extenuation, of that marvellous self-delusion which difterentiates him among barl men.

* B. iv., part ii., $343 r$. $\dagger$ Sp., iv., 2*) 2. 
III.-PREPARATIONS FOR THE TRIAL.

The first overt difference between the king and Wolsey was manifested when the cardinal filled up the vacant post of Abbess of the Convent of IVilton. There were two competitors: Eleanor, sister of William Carey, the husband of Mary Boleyn, Anne's sister; and Isabella .Jordan, sister of the Abbess of Syon. The sympathies of the court were warm on the side of Eleanor, who, however, on close serutiny, eonfessed to having given birth to two children 'by two several priests,' and to having been subsequently kept, 'not long ago,' by a servant of Lord Broke. Isabella, on the other hand, was 'aneient, wise, and discreet,' although, in a chapter of earlier life, pages of impure record were unrolled in her case also. It was Henry's conviction, expressed in a letter to Anne, that, under such circumstances, it would be better that both eandidates should be set aside, and some other good and well-disposed woman be appointed, 'whereby;' said he, 'the house shall be the better reformed, whereof, I ensure you, it hath much neel.'*

Wolsey, however, nominated Isabella to the post of abbess. The king was much irritated, and informed the cardinal of his grave displeasure in the plain, straightforward language habitual with him. Wolsey's reply was in a strain of humble submissiveness. He alleged his ignorance of the royal will, the sickness of his servants, his own fear of the sweat, which had been raging around, and observed, further, that his appointment had been merely 'conditional.' 'The king's

* B. iv., part ii., $4197,447 \overline{7}, 4507-9,4528-9,4950$. The preceding abless died April $24,152 x$. Istbella s election was confirmed November 13 ; two days later she was justalled. 
wrath was mollified, but he elosed the correspondence with a highly eharacteristic epistle, wherein he made allusion to another topie of eomplaint arainst the eardinal, the many indecorous artifices resorted to by him to extort funds for founding Cardinal College. 'They say,' wrote Henry, 'that the college is a cloak for all mischief. I perceive by your letter that you have reeeived money of the exempts for having their old visitors. If your legateship is a eloak apud lomines it is not cpued Deum. I doubt not, therefore, that you will desist; and in so doing we will sing, the luudunt Angeli, atque Archengeli, te luedut ommis spiritus. Thus I end this rude yet loving letter, assuring you that at this hour there remains no spark of displeasure towards you in my heart.'

Wolsey was thus under a partial cloud, at the very time that, not without some serious prognostics of evil, he was awaiting the arrival of his colleague in the divorce trial; to whom, by pontifical arrangement, he was himself to be really little more than assessor. As though troubles were approaching, he unbosomed his anxieties in some measure to the French ambassador, and declared that if he could only see a firm amity 'established between the nations, a reform of the laws and eustoms of the country,' the king married, and blessed with a male heir, he should be glad to retire, relinquish politics, and 'serve God to the end of his days.' On the issue of the trial he well knew that his own fortunes in the future must depend. Whatever might linger of the frown on the royal brow would quite vanish, and the blandest smiles would sueeeed, if only Henry's matrimonial eaprice should now be confirmed by pontifical warrant.

Lorenzo (Lawrence) Campeggio was in high favour with Clement, whom he had represented in the Nimemberg Diet, and whose legate in his captivity he had been with signal approval at liome. He was in no less favour with Henry, whose interests he had undertaken to uphold at the Vatican, and to whom he owed mueh-his house at Rome, loans of money, the bishopric of Salisbury; from whom, too, by timely subservieney, he might expect the wealthier see of Durham. Campeggio was to be himself the bearer of the Commission 
Decretul, * long and earnestly petitioned for, and now at last contided to the legate's trusty hands, with the express command, however, that it should not for a moment be suffered to pass into any other hands on any pretence whatever. But Campeggio's journey was still delayed, and Wolsey suspected that Clement was purposely detaining the legate until the future of Italy had more unmistakably revealed itself, and the answer to the question which of the royal antagonists would come off victorious had been reduced to a moral certainty.

The summer of 1528 was unhealthy on the Continent; in England the sickness was almost unprecedented. Among the annual mortality, the deaths of Sir IVilliam Compton, and of William Carey, the husband of Mary Boleyn, were recorded. The scourge of small-pox in the spring was followed by the sweating sickness in the summer. Even the administration of justice was deferred. When 'divers of the queen's maidens' were attacked with small-pox, Anne was removed by her stepmother to 'the gallery in the tiit-yard.' But in the middle of July Anne was 'taken with the sweat.' Henry sent to her liutts, his second physician-his first physician, Chambers, being absent-and, under judicious treatment, her health was rapiclly restored. The French ambassador communicated to his court the tidings (July 21), 'Mademoiselle de loulan and her father have sweated, and have got over it.' The king was in trepidation for himself; made his will, like tens of thousands of his subjects; 'received his IIalier'; set himself 'right anenst God,' and confessed himself every day; and at the same time adopted the precaution of moving from spot to spot, to avoid infection, having tires lighted wherever he stayed, to purify the atmosphere. He was anxious also on Wolsey's account, and advised his minister by letter to "keep a small and elean company,' to use 'small suppers,' drink but little wine, and to take 'once a week the pills of Rasis.' IVolsey escaped the malady. The P'rineess Mary caught the infection, but was soon convalescent again. Early in the

* Wolsey to Sir G. Casale, (Oetober 4, 1528: - I find it absolutely necessary that the Decretal Bull, which Campeggio brings with him, should be secretly shown to some of the king's council', ete.-B. iv., part ii., 4813 . 
autumn Henry had outlived his terrors, and was in good spirits at the recovery of his daughter and of his mistress.

Campeggio continued his proerastinations, but at length (June 11) Gardiner despatched the intelligence that the legate was on the point of setting forward. And, in fact, Campeggio embarked July 2.5 at Corneto for Marseilles. Yet it was late in August ere he reached Lyons; and thenceforward his progress was still very slow, attacks of the gout in quick suecession, actual or diplomatic, furnishing an excuse for extreme dilatoriness. Conducted through France in a litter, with Clerk, Bishop of Bath, in close attendance-for Gardiner had now been sent on to Venice, ${ }^{*}$ to arrange the matters in dis. pute with the signory to Clement's satisfaction-it was not until Monday, September 14, that Campeggio was reeeived at Paris, late in the evening, by a concuurse of fifteen or sixteen bishops. From Canterbury (October 1) Campeggio sent letters to Henry and Wolsey, wherein he eomplained much of his sufterings from the gout. He did not arrive in London until the end of the first week of October. Du Bellay forwarded the news to the French court, October 6 : 'Campeggio will arrive to-morrow; the legate will go to meet him as far as the house of the Duke of suffolk.' Here, avoiding the display and parade which Wolsey would have liked-such as had welcomed the shrewd Bolognese prelate, ten years before, to the English metropolis on his former visit-he stayed one day only, and then 'passed secretly by water,' in the evening, without noise or pomp, to Bath Place, without Temple Bar. This mansion, named from the see to which it belonged, had been prepared for his reception. The gouty legate at once betook himself to his bed.

The delays, skilfully justified by a variety of pretenees, had exactly answered the pope's intention. Early in 1.52s, as has been narrated, the heralds of France and England had deelared war against the emperor with all due form and solemnity. To Henry Charles replied with respeetful deeency, but the French monareh he vilified as a traitor to his promises, and a stranger

* 'Last evening an ambassador from the King of England, named Doctor Stephen . . . arrived at Venice. He came riding post. He was lodged in Cit Dandolu at the Ponte della Paglia, with the other English ambassador, Prothonotary Casal.'-'Sanuto Diaries,' June 24, 1528. 'Ven., iv., $31 \%$. 
to that sense of honour which distinguishes the gentleman. Franeis retaliated with the equally offensive retort that ('harles 'lyed falsely in his throat.' He challenged the emperor to deeide the controversy by single combat, without further imperilling the lives of their subjeets. And although the ehallenge and its prompt aeceptance never resulted in the proposed personal encounter of the two most powerful sovereigns of their age,* their reciproeal animosity became only the more embittered.

At first the French arms seemed likely to win the mastery. A naval victory off Naples, and the surrender of some small towns to Lautree, raised high the expectations of Franeis and Henry. But in the middle of August. Lautrec himself and nearly two-thirds of his force on the plains around Naples perished under the stroke of pestilence. The surviving remnant moved three miles oft, and under their new general, the Marquis of Saluzzo, flattered themselves with the too sanguine hope of yet retrieving their fortmes. The issue of the struggle proved disastrous to France. Elsewhere, as well as hefore Niples, success attended the imperial arms. And now Clement's attitude towards the divorce question became really tinally determined. Thenceforward to comply with Henry's demand might well, as Gardiner said, be in the pope's 'paternoster,' but it was 'nothing in his ereed.' 'Nothing is more certain,' Norfolk flatly remarked to C'hapuys a little later, "than that the pope in this, and every other ease, will do the emperor's bidding, even if he were asked to dance in the pullic streets in a jester's jacket.'

This thorough failure of their expectations miserably disapprinted the allied monarehs, and caused Wolsey a sad bout of illness and depression. It proved, however, under a mereiful proviclence, the means of resening England from papal thraldom.t Charles himself, with his eharacteristie prudenee,

* 13, ir. part ii.. $+111,4 ! 31$. Ven., iv., 345. Charles complained to Henry (November, 1.2, that Francis refused to accept his letters, wherem he indicated 'a safe rendezvons for the deed.'

$\dagger$ Sanga to Campeggio, september 16, 1528: "If the pope would incur merely personal danger, his love and obligations to the king are so great that he would content him unhesitatingly; but as this involves the certain ruin of the Apostolie see and the Church, orcing to rectit events, the pope must beware,' ete.-13. iv., part ii., 4737. 'sp., iv., 373. 
held out the olive-branch at this juncture to clement; and besides taking in hand to reinstate the Medici in the government of Florence, made the pontiff other seductive promises of full support. But, beyond such inducements, the dread that Charles would shortly descend in person into Italy, of which he was now master, impelled Clement, by fear as well as hope, to draw nearer and nearer to the imperial party. (on the other hand, the fortunes of France were continuously on the wane. At the very moment that Campeggio was reaching London Lee wrote to Henry: 'It is reported that the French host at Naples is wholly vanquished, that the French have lost Genoa,' etc. 'Thus it was to no purpose that Henry and Francis devised the plan of providing Clement with a 'convenient presidy, or body-guard of fifteen hundred or two thousand picked men, or that they suggested the migration of his holiness from Rome to Nice or Avignon, in order to assure his strict impartiality. All that they could offer was outstripped by the manifest advantages of friendly understanding with the victorious Charles. And thus the pontiff's choice of sides was deliberately settled ere Campeggio set foot upon English soil. To amuse Henry for a while with the semblance of judicial rectitude, and to avoid giving needless oftence to personal or national susceptibilities, had become the principal part of the Italian legate's real business.

Campegrio commenced proceedings by sounding the mind of his fellow-legate; and Wolsey dirl not fail to reiterate the warning that unless the sentence of divoree were pronounced England would infallibly follow the heretical lead of Germany. Remedies hostile to the papacy, he said, were frequently instilled into the royal ear. Campeggio was next favoured by the king with sereral suceessive audiences. And Henry paid the Roman legate a personal visit in return (Friday, October 23), and conversed with him for four hours together. At this interview the doggedness of the royal temper was unmistakably revealed. Campeggio essayed various arguments to prevail upon Henry to abandon the divoree, but was foiled at every point. The king showed himself a master of the question in all its bearings. He was no longer living, he 
averred, in mortal sin; he had not for a long time cohabited with Katharine, and he never would do so again.

The next day Campeggio was eonreyed by Wolsey in a barge to visit the queen, after that he had, in a previous short private interview, rearl aloud the Commission Decretul to Henry, retaining it all the while pertinaciously in his own hands. To Katharine the legate presented a letter from the pontift, and proceeded to commel her not to press the cause to a legal verdict, but to adopt rather some other course with becoming good sense. Would she not, after the examples of Juana of Castile and of Jeamne of Franee, embrace a religious life? By such means, he suggested, she would preserve her dower, which otherwise, if the deeision went against her, would be forfeited ; she would enjoy the guardianship of her daughter and her own rank as princess, and she would offend neither God nor her own conscience. But Katharine proved quite as renolute as Henry. Although, as Campeggio described her, 'very religious and extremely patient,' she was intractable on the one topic of her marriage. $A$ stranger herself in England, and without friends, she must demand of the king, she said, the assistance of counsellors. she further begged of Henry the permission to confess herself to Campergio. Confession in the Roman Church is rendered more solemn by the sacred seal of secreey. But the confession for which Katharine craved leave was to be protected by no such mysterious seal. It was to be made under the peculiar indulgence of publication to the pontitt, and thus to Christendom. The motive was obvious. Katharine hoped to influenee the pontitt, and her judges, and Christendon in her behalf. Her confession (nine in the morning, October 20i) assured Campegrio that when she wedded Henry she was as 'untoucher as she came from her mother's womb' ('intoccata, come venne dal ventre di sui madre').*

* 13. iv., part ii., 4875. 'Margaret, wife of Thos. Clerke, heard her master, Sir (reo. Wolleston, at Hapthorpe, half a year after Prince Arthur's death, inquire of Sir Davy Philippes the cause ; the latter said that "as far as he could perceive it was the of accompanying with the lady Katharine,"' etc. - See also 13. vii., 12.'. 'The evidence of the completion of the nuptials was considerably stronger than is usual in the case of a childless matron.'-Mackintosh's 'England,' ii., p. 150. See Sp, iv., 302, 419, 4.t; Ven., iv., 9.5; B. iv. part ii., 465.; part iii, 5it, 6094 ; 
A difticult problem had been further entangled by a new knot, to unrivel which was judged to be a necessary preliminary to the trial. A brief had been adduced of the same date as the Bull (December 26,1503 ), which was free from the objections which, according to the king's advocates, invalidated the Buil. Of this brief a copy was sent by Campeggio to Katharine. But the interposed brief, while aftording legal support to her cause, placed the queen in an extremely painful dilemma. In the Bull it was stated that the marriage with Arthur had perhaps (forsan) been consummated. The brief atfirmed the consummation, without any perhaps, as an undoubted fact. Thus the position of non-consummation which Katharine had ostentatiously taken up, and on which she relied, was broken down by the very document, introduced in support of the validity of her wedlock. At the same time, therefore, that she propounded the brief, she felt it incumbent upon her to make a notification-which she did November 7 , 1528-the Archbishop of Canterbury and the Bishops of London, Bath, Rochester and St. Asaph being witnesses thereto-that she did 'not intend to admit any presumption (of consummation) drawn therefrom.'

Could the brief be genuine? This question, of necessity, for the time engrossed attention, and engaged Henry and his emissaries for many months in anxious investigation. It thus effectually served the settled purpose of procrastination, which the Imperialists still pursued by every available means.

Fault was found with Katharine for not having earlier produced the brief, which she professed to have had in her keeping for some time. Her general behaviour, too, was remarked upon by the partisans of the king, much to her disparagement. Henry was 'in great pensiveness'; Katharine evinced many 'signs and tokens to the contrary; she exhorted the ladies and gentlemen of her court to dance' at a time when, said some of the anti-papal section, it would be 'more becoming to exhort them to pray.' That such words should have found voice eren in the council-room itself is evidence of the

Appendix, 2211 ; Singer's 'Ca vendish,' ii., p. 289 ; Hall's 'Chronicle' (1809), p. 757. Chapuys regarded the plea of non-consummation as untenable, and had the honesty to say so. 
inerease of the Protestant party both in influence and in numbers. By the adherents of this party Katharine was censured with acrimony for 'showing herself much to the people, and 'rejoicing greatly in their acclamations, beckoning with the head, and smiling.' The outraged queen was a favourite with the populace; on the other hand, the indignation against Anne was deep and loud, especially on the part of the women. Henry himself noticed the direction of popular sympathy, and frequently declared that, should any man speak in other terms than he ought of his prince, he 'would let him know that he was master ;' there was 'no head so dignitied that he would not make it fly.'

Among the upper ranks especially, the brief was much eanvassed. By Henry's party it was maintained that, as 'a Bull is of more power than a brief, and not much more expensive,' the probability was that 'the brief had been lately concocted to exclude the only exeeption in the Bull.' The brief could not be found in England. The emperor held the brief, and was willing to forward a 'transumpt' to London, but refuser to send the original. He was willing to send the original to Rome; for it was there, lie argued, that justice required that the suit should be decided. The sending it to Rome, however, was still postponed. Katharine herself was even compelled by Henry, under oath, to write to her nephew and request him to forward the original doeument to the legates. This request, however, she very eleverly contrived by a seeret messenger to countermand.

Henry's ambassadors, (ihinueei and Lce, were allowed to examine (April 11, 1529) the professed original in Spain. They reported from Saragossa (April 20) that the brief was most suspicious, the seal being apparently 'old wax over new.' Careful search was instituted at Rome itself by Casale, and no entry of the brief could be discovered in the registers, although there were entries of the same day, as well as both immediately before and after it. That it was a forgery was, moreover, attested, it was eontenderl, by its identity of date with the Bull; for a Bull and a brief bore date from ditterent commencements of time. A brief was dated 'uncler the fisherman's ring from the nativity of christ;' and according 
to such a computation, the date would fall on a day before Julius became pope. The customary clauses, too, were absent. And the spelling of sundry words was incorrect; whereas no such errors could be detected in other writings of Sigismund, the pontifical secretary at the time. Supposing it, however, possible that the brief might be genuine, by what argument, it was inquired, could a dispensation under wax be held to supersede a dispensation under lead ?*

On the other hand, the Imperialists asserted that the brief had been found with Gonsalvo Fernandez, chaplain to the emperor, and nephew to Dr. de Peohebla (Puebla), otherwise called Mancus, whom Isabella had employed in negotiating her daughter's two marriages. Isabella, they stated, being ill, had desired to see the dispensation before she died; and on this account it had been sent into Spain, under strict promise that it should be kept secret; and this might be the explanation of its remaining unregistered, or of 'the register being hidden.' Considering the distressing events which had now come to pass, they professed their belief that in His Divine foresight ' the Holy Ghost had preserved it.' +

Henry made application to the pope himself to resolve the contested question concerning the brief. 'The king, having his mind fixed on the certainty of eternal life, hath in this cause put before his eyen the light and shining brightness of truth . . . and therefore recurred to the only fountain of remedy on earth, the pope himself.' At a later period Henry imputed the fascination exerted over him by Anne to 'witcheraft '; he was, like the hero of Cervantes, the victim of 'enchantment.' What a strange and fast spell must indeed have bewildered him, if he actually imagined that in the midst of the imperial triumphs the pontilf-and that pontiff Clement VII.-would pronounce a document which Charles guarded with jealous care a trumpery forgery! Clement might whisper to his secretary, or even communicate privately to Gardiner, his conviction that the brief was spurions:+ he might delegate to

* B. iv., part ii., 4741-2, 4977-8, 51).3.3 ; part iii., 5154-6, 5177. 5375-6, 54t0) ; Nares' Burnet,' part i., book ii., pp. 91-3.

$\dagger$ B. iv., part iii., 5423, 5469 .

+ Campeggio to Salviati, June 29, 1529: 'Dr. Stephen [Crardiner, who 
seleeted eardinals the examination of the knotty question; but of eourse, in the face of the world, he absolutely refused to decree the brief ' false.'

Far from diminishing, Clement's nervous apprehensions were augmenting. And thus in midwinter he despatched his chamberlain, Campano, to England, where he arrived Deeember 28. The objects of his mission were to renew the assuranees of papal goodwill, to treat of the indietion of a general eouneil, to eonfirm Campeggio in his policy of delay and ambiguity, and, above all, to burn the terrible Commission Decretal* or to ascertain for a certainty that it had been burned. When this safe destruction had been accomplished beyond doubt, Clement was able to breathe with more freedom. On Campeggio's suecessful dilatoriness he bestowed the commendation it well deserved at his hands, and reiterated his injunetion, 'the process must be slow, and no sentence must in any wise be pronouneed: you have sustained this burden until now with great dexterity and patienee; and therefore the pope doubts not you will in like manner sustain it until such time as your coumsel to eite the cause hither can be followed with less offence to the king's mind.' The admonition to forbear haste Clement himself habitually put in practiee. Tidings eame from Rome: 'The Cardinal St. (?uatuor is erery other day sickly; usually, when the cardinal is whole the pope is sick.' In England time wore merrily on amid banquets and pageants. Fîtes were given by Henry and his minister in Campeggio's honour. Farees were played with much display at great eost, the dialogue always ' in French,' aecording to Wolsey's explicit direetion.

Clement's state of health had been for some time very preearious. Information reacher Wolsey in a letter from Veniee, dated lamuary 21, 15.2!, "The pope is dead, . . . he was taken ill at Mlass on the Epiphany.' In February rumours of Clement's decease were in general circulation throughout the Continent, and in England the report of the

had just returned] reports that his holiness told him that the brief was spurious. - B. iv., part iii., 57333.

* Clement had granted the Decretal merely ' to be shown to the king, and forthwith burned.'-13. iv., part ii., 5n:38. 
pontiff"s death stirred up Henry to seize the welcome opportunity. At Rome cabals and intrigues were forthwith rife: the Colonna at once braced themselves for a struggle against Farnese and the Cardinal of Mantua* In England Henry immediately adopted active measures to secure the election of Wolsey to the vacant throne. The Cardinal of York, the king insisted, was the most fitting person to conclude, as mediator, the universal peace, so ardently desired ; to restore to the holy see her possessions and dignity-for the emperor still kept his hands on Ostia and Civita Vecchia, notwithstanding Clement's return to his capital; and, finally, to settle with absolute impartiality the royal matrimonial cause. Francis also exerted his best endeavours in Wolsey's interests, in hearty sympathy with his ally and brother. For this purpose he commissioned to Rome Du Bellay, his ambassador at the English court, Bishop of Bayonne. And in his rapid journey from London, Du Bellay had pressed on to Clermont, near Paris, ere he received reliable intelligence that public judgment had been too hasty, for Clement was not only yet alive, but was likely to recover; and on March 18 Clement himself despatched a notification to Wolsey of his convalescence.

Yet even at this juncture, when Henry had just permitted Wolsey to enter upon the see of Winchester, on his resignation of Durham, and was earnest in his efforts to put the tiara itself upon his head, the slippery condition of the great Cardinal of England's power and splendour betrayed itself to the eye that scrutinized behind the scenes. Anne was of all the nearest to the king's person, and more powerful than any cardinal or duke; and she was dissatisfied with Wolsey, and had become in heart his malicious enemy. She had not forgotten that the cardinal had once warned his sovereign to shun wedlock with her as he would 'shun present death.' She imputed to Wolsey the tedious postponement of the matrimonial suit. The cardinal, she persuaded herself, was placing impediments in the way of her nuptials, lest her paramount influence, if she became queen, should effectually dwarf and humble his own power. Yor was Anne alone in $101-7$.

* B. iv., part iii., 5194, 5269-74 ; Nares' 'Burnet', part i., book ii., pp. 
her dislike and suspicion. Her father, and the two dukes, jealous of the cardinal, leaned to her estimate of his duplieity and seeret opposition. Thus, a conspiracy, strong and rigilant, was already on foot to work the eardinal's overthrow. A dire storm was brewing, which on the first farourable moment was sure to burst in scathing fury on Wolsey's devoted head.

The wearisome negotiations continued respecting the brief, and various other difficulties eomnected with the dirorce eause. Strange as it must appear, even at this stage in the trans. actions, a new commission was demanded, and together with it a Pollicitation, which, in default of the exhibition of the Commission Decretal, might bind the Proteus pontift' not to revoke the cause, but to accord full sanction to its tinal determination by the legates themselves.

Had the trial of the suit been deferred until all the contested points had been satisfactorily arranged, it would have been deferred to the Greek kialends. Clement's anxieties were not lullerl to rest; he was, on the eontrary, growing less and less tractable. Thus, the discussions about the brief were broken oft, and Wolsey sent instructions to the English envoy at Rome to dissuade the pope from sending to Spain for the original brief. 'A commandment' was even to be obtained from Clement that 'no further mention be made of it.' For startling information had been communicated, on authentic grounds, to the English eourt. Formalities had already been gone through at Rome which threatened the revoeation of the eause. Henry and his court suddenly took the alarm, and were arousell to prompt action for the determination of the main question, dismissing all minor inquiries.

No time was to be lost. The ling, therefore, issued, May 30,1529 , his writ for the legates to try the cause ; and the following day they opened their court ' in the l'arliament chamber, near the Friars l'reachers (Blackfriars).' Thus, after vexatious delays, and busy discussions of problems which seemed to defy solution in the excited temper of the partisan mind, the legal process was legun with a speed which was regarded by the untside world as even abrupt. 
IV.-THE TRIAL.

'The court was platted,' writes Raphael Holinshed, 'in tables and benches in manner of a consistory, one seat raised higher for the judges to sit in. Then, as it were, in the midst of the said judges, aloft above them three degrees high, was a eloth of estate hanged, with a chair royal under the same, wherein sat the king; and besides him, some distance from him, sat the queen, and under the judges' feet sat the scribes and other officers: the ehief seribe was Doctor Stevens (Gardiner), and the caller of the court was one Cooke, of Winchester.'

The king and queen had been eited for Friday, June 18. The king appeared by proxy; Katharine in person. She entered her protest against the jurisdiction of the legates, and made her appeal to the pope. The legates registered her protest, and eited her to reappear on Monday, June 21, to 'hear their decision about her protestation.' On Monday, June 21, both the king and the queen appeared in person.* And then it was that that memorable incident oceurred, which, depicted by the greatest of dramatists in colours that will not fade, however much questioned by some historians as apocryphal, and even altogether rejeeted by others, has now been proved to rest on substantial faet.

The king spoke first. Turning to the two cardinals, he declared his resolution no longer to remain in mortal sin, as he had done for twenty years. Next Wolsey addressed the court, and, defending his character from the imputation of partiality, asserted his fixed purpose to do justice. Then

* Holinshed, iv., pp. 967, etc. ; B. iv., part iii., 5694, 5707. Gardiner was not present until some days after the opening of the court. By June 25 he had returned home. His letter of that date from Westmiuster to the English envoys at Rome says, 'I have arrived safe, and told the king in what state his affairs stand.'-B. iv., part iii., 5715. 
Katharine arose, and moving from the left, where her throne had been set, 'on a lower level' than the king's, under a canopy of cloth of gold, to the right, where Henry sat, she knelt down at her husband's feet, and addressed him in broken English. The king twice essayed to raise her, but twice she fell again upon her knees, and implored him to have pity upon her, 'a woman,' she said, 'a stranger, born out of his dominions.' For twenty years she had been his faithful and obedient wife. She entreated him to consider her honour, his daughter's, his own, the reputation of her nation, and of her relatives. With the emperor she must implore for herself full permission to communicate by letter and messenger. Forasmuch as Henry had expressed his desire that their union should be pronounced valid, and hat acknowledged his great love for her, she had appealed to Rome. There the cause would be decided without partiality or suspicion. To Rome only would she make her answer.

Then rising up, with a low courtesy to the king, she withdrew, but not back again to her former seat. She passed straight out of the court, leaning on the arm of Griftin Richardes* (Shakspere's 'Master Griffith'), an attendant, who was her general receiver. The king, disconcerted by her departure, commanded her to be summoned back. 'Madam,' said Griftin, 'ye be called again.' 'On, sir,' replied Katharine, with peremptory firmness, "it is no indifferent court for me; I will not tarry.' After her departure, the king, in whom there still remained some roots of his better nature, enlarged in terms of high eneomium upon her many virtues and noble qualities.

The eardinal then humbly besought the king to bear witness whether, according to the malignant accusations of current rumour, he had been the chief mover in this divoree cause. Henry, in reply, exonerated Wolsey entirely. The cardinal, he said, had rather been an opponent; his own scruples had been the origin, the painful misgivings of his conseience, which had been aroused by a doubt cast by the Freneh ambassador upon the legitimacy of the l'rincess Mary.

Katharine was eited to appear again in Court the next

* Later on, instructions are addressed to Lord Mountjoye and Gryffith. Mountjoye's lieport has the name of Richerd Grytiyth.-B. vi., 759, T65. 
Friday, and was thrice summoned; but she remained unshaken in her resolution to abstain from entering the court again. She was accordingly pronounced contumacious. It may be added that at both of her two appearances before the legates, at her entrance and departure from the court, the women, as ever, openly and enthusiastically demonstrated their sympathy with her cause, encouraging her to courageous steadfastness in maintaining her matrimonial rights by loud acclamations.

The touching scene between husband and wife of June 21 , briefly described, has been often regarded as an impressive fiction. This is the more difticult to be accounted for because the speeches are recorded by Cavendish at some length, probably from notes taken down at the time by some who were present. Edward Hall gives only the king's speech, and states that Katharine delivered hers in French. Holinshed confuses the days, but places in Katharine's mouth words resembling those which she must have really uttered. Burnet is strikingly inconsistent with himself. He prefaces his narrative with the words: 'As for the formal speeches which the king and queen made, Hall, who never failed in trifles, sets them down, which I incline to believe they really spoke; for with the journals of the court I find those speeches written down, though not as a part of the journal.' He prints also in his 'Records' a letter of Henry which distinguishes the two days, and declares expressly that both he himself and Katharine on .June 21 appeared in person. Yet in his last volume Burnet confounds the proceedings of June 18 with those of June 21, and pronounces the speeches attributed to Henry and Katharine to be 'plain falsities.' Besides Henry's letter to his agents at Rome, there is also a letter of Du Bellay to Francis, which presents a correct summary of Katharine's speech, but confuses the proceedings of the two days on which Katharine made her appearance in court. A letter, however, of Lodovico Falier, the Venetian ambassador, distinguishes the days, and accurately assigns to .June 21 Katharine's humble but dignified address to her husband.*

* Singer's 'Cavendish' i., pp. 146-54; Hall's 'Chronicle' (1809), p. 757 ; Holinshed, iv., p. 907 ; Nares' 'Burnet; part i., book ii., 1. 117, and book iii., p. 46. See B. iv., part iii., 570.2, 5707; Ven., iv. 45.2. 
The distinetion between the proeeedings of the two days has now been made palpably clear, together with the chief points of Katharine's address on the seeond day. A recentlydiscovered letter of ('ampegrio himself, in eypher, Jtalian and Latin intermixed here and there with words of no meaning, addressed to Jacobo Salviati, Clement's seeretary, is perfectly eonclusive. The real historieal basis of the interesting scene, with the speech aseribed to Katharine, as already quoted, has thus been established beyond contradiction. Campeggio's letter, eopied by Mr. Stevenson from the original itself (which is among the secret archives of the Vatican), has been printed by Brewer in the Appentix to his Introduction to vol. iv.*

At the fifth session (Jume 2s) Fisher of Rochester presented his book on the legality of the marriage, and, already animated with the intrepid spirit of the martyr, leelared that ' in is former audience he had heard the king's najesty disenss the canse, and testify before all that his only intention was to get justice done. . . He had therefore come forward, after the most diligent study of the matter for two years,' in order to avert the damnation of his own soul, and to be faithful to his king. The marriage, he declared, can be 'dissolved by no power, human or Livine.' Subsequently Henry himself replied to Fisher, or rather inveighed against him with acrimonious virulence. Nor, although the martyrdom which the bishop seemed to court was postponed, was his ontspoken opposition ever forgotten.

The legates now proceeded to the examination of witnesses. Their attention was principally directed to the question of consummation, and here Fisher and Wolsey came into sharp collision.

Neanwhile, at Rome, the Imperialists pressed more vigorously than ever for the Adeocution. The prospect of the eniperor's

* Campegaio to J. Satriati. June 221, 1.i29: "Alli dicedotto (on the eighteenth) chi fu il di di la citatione comparse la Reina personalmente ; huggi alli vinteno to-day, on the twenty-first) lei ha interposto una amplissima appellatione et supplicatimem ad Pontificem, et recessit : ma prima ibi coram tribunali genutlexa, benche il Re due volte la sollevasse, dimando licentia ai Re, ehe per trattarsi del honore et conscientia sua ru (et) de la casa di spagna, le volessi concedere libero adito di scrivere et manlar messi a Cesare,' etc.-B. iv., Intro. Appendix, delxxi.-ii., and pp. cced $x x_{\text {i. }}$ iil 
speedy visit to Italy added strength to their arguments. Of small avail was it that the English ambassarlors descanted on Henry's superlative merits, Wolsey's inevitable ruin, the loss of France and England to the papacy. Clement conld only weep and murmur that he was "placed between the hammer and the anvil,' and invoke death to relieve him of his troubles.

Early in July Katharine's 'Procuration, to procure the revocation,' drawn up by Flemish lawyers, reached Mai-a Spanish gentleman of Barcelona, who was then imperial ambassador at Rome-through the intervention of the Lady Margaret. 'We shall now speak plainly,' wrote Mai to the emperor. In the same letter the ambassador expressed his grave suspicion of Campeggio. 'He has behaved so barly,' wrote Mai, 'that nothing could be worse.'

Clement's precarions health, and the importance of Wolsey's presence on the Continent to bear part in the negotiations for a universal peace, were urged by Henry's partisans as reasions for hurrying on the suit. 'Some expect sentence,' wrote Campeggio to Rome (July 13), 'within ten days; and although we have many things to do-writings, allegations, and processes to see and examine-nothing is sufficient to procure us a moment's breathing-time.' His representations were no doubt intended to set Clement's timidity on the fret, so as to hasten the Advocation. Thus Clement, too, was becoming more and more impatient. 'The cause is hurried on,' he complained; and he declared that he neither could nor would 'wait any longer.' The Roman legate's temper was tried by the English climate as well as by the demands made upon his energies to obtain increased speed in the legal process. In Jume the Italian prelate shivered in his warmest garments; in July the weather had changed, and extreme heat had set in.

By the king's adherents Wolsey was as fiercely calumniated as Campegrio by the Imperialists. His yielding precedence to his Roman colleague in the management of the suit was animadverted upon; but his humility, however umnatural, is explained by his spirit of professed deference to the pontitt's authority, and by his sincere wish to be screened from needless 
responsibility. The large correspondence now made public acquits him in its every line of disloyalty to his master. Campegrgio was even of opinion that Wolsey loved his king better than he loved himself. Vannes reported that Wolsey had threatened Clement, as he had before threatened Charles, that, ' unless he complied with the king's request, he would find some means to make his holiness repent. ${ }^{*}$ His devotion to the papacy, of which he was regarded as a principal pillar, and his devotion to his sovereign, it might be supposed, drew his sympathies in counter directions; but it was not so in reality. He was impelled by both these motives to the same line of conduct. The divorce he judged necessary for securing the royal succession; and that the divoree should be pronounced by Clement he judged necessary for maintaining ecelesiastical authority and the continued adherence of England to the holy see. Among the self-sacrificing cavaliers of a century and a quarter later, not one could be pointed out whose loyalty to the throne was more unsullied or more fervid than Irolsey's. In his ease personal attachment to the monarch was largely l,lended with the most absolute attachment to the monarchical prineiple itself.

The delivery of the sentence had been fixed for Wednesday, July 21 , but on that day the court was prorogued until the following Friday. On Friday, July 2:3, Campeggio rose before an assembly of bishops, nobles and gentlemen, all on the tiptoe of expectation, the king' himself sitting 'within a gallery near the door of the eourt,' and pronomeed in fluent Latin, 'on the word of a true prelate,' that 'the general holidays of the harvest and vintage being observed in the court of Rome at that season every year, the legates are bound to obey the style of the same court; and, therefore, proceedings must be prorogned until October 1 next ensuing.' †

The sentence of postponement was received with the silence of consternation. 'Then a hum of dissatisfaction was rising, when the lnke of Suftolk, 'giving a great slap on the table,' exclaimed, "liy the Mass! now I see that the old said saw is

* B. iv., part iii., sitt!.

$\dagger$ Campeggio redeemed his promise to Clement: "They shall never learn my opinion until $I$ am about to give judgment ; that is to say, if the eause should proceed so firr.'-B. iv., part ii., 4736. 
true, that there never was legate nor cardinal that did good in England.* Wolsey sharply retorted, aceording to Cavendish, 'Sir, if I, simple cardinal, had not been, you should have had at this present no heal on your shoulders, wherein you should have a tongue to make any such report in despite of us.' The cardinal's apt reminiscence was not likely to heal Suffoll's festering malice. The lords departed in stormy indignation. The legates were left alone, looking one another in the face; and vexed and blank must Wolsey's face have been. He would himself have preferred to proceed with the divorce case, but he was constrained to succumb to Campeggio's $\uparrow$ resolution and the pontiff's will.

To the king himself this postponement of his cause can hardly have occasioned any great surprise. Henry had been warned from various quarters of the unfavourable tendency of the papal deliberations; and that he in some measure appreciated the intelligence which reached him appears certain. He had despatched Gardiner to Venice, instructing him to persuade the signory to restore Cervia and Ravenna to the Roman see. But after Gardiner's return, towards the end of June, the royal zeal in the pontifical cause har perceptibly cooled. The plain inference is, that what would be the outcome of Clement's calm reflections, notwithstanding his actual promise at an early period not to revole the commission, was now not dimly foreseen.

In the midst of the busy interest excited by the matrimonial suit, Sir Thomas More took his departure (July 1) for Cambray, to assist, as Henry's representative, in concluding the terms of a universal peace. T'unstal, Bishop of Londondescribed by 'Tyndale as a 'taciturn Saturn,' by More as an 'agreeable companion'-was his colleague in this embassy. But, lawyer, wit, and man of letters as Hore was, he could not be reckoned a match for Wolsey in statesmanship and diplomacy. The cardinal's heart was at Cambray, although the ugly divorce business and its consequences detained him a prisoner in England. His absence was certainly no matter of regret to the Lady Margaret.

* 'These Romish hats never brought good into England.'-Latimer's 'Sermons,' P.S., p. 119.

+ Ven., iv. $4: 2$. 
The 'two ladies,' or, rather, the 'two sisters'-for so they styled themselves-Margaret, dowager of Savoy, on the part of her nephew, accompanied by the Cardinal of Liège; and Louise, Duchess of Angouleme, mother of Francis, attended by ladies in litters and on horseback, and amongst these by her celebrated daughter Marguerite, met at Cambray early in July. The two astute plenipotentiaries arranged the terms of the much-desired peace ere many days of consultation had passed. The ladies were lodged in such close proximity that they could at any time exchange communications through a gallery. A previous correspondence by letter had prepared the way for the speedy settlement of the terms of peace.

The Treaty of Madrid was the basis of the Treaty of Cambray. Francis was willing to submit to concessions, which might be even deemed somewhat humiliating, in order to regain his sons, whose ransom was tixed at two million crowns. To the interests of his allies generally the French monarch showed himself indifferent, although he paid much ontward deference to his 'brother' of England, whose monetary assistance he knew would be required to defray the heary ranson. Charles, on his part, exhibited a consideration for the representatives of the unfortunate Bourbon, which appeared yet more marked by striking contrast. This consideration must have been the result of long-sighted calculation, for there is no instance of (harles having been ever betrayed into 'an meonscions fit of romance or generosity.' 'Threatened by the Turk, opposer by the (ierman l'rotestants, assailed by the Italian confederates, eonfronted by the uniterl power of Francis and Henry, notwithstanding the signal sucess of his arms by land and sea, he was by no means reluctant to accede to terms which comprised all his reasonable demands, whilst Fortme still extenterl her fickle favours towarls him.

It is a sign of the age, as well as of the kindly sentiments of the larly plenipotentiaries, that it was expressly stipulated that Francis should at once consumuate his marriage with Leonora.* And, accordingly, a year later a boat left the

* The terms of the treaty on this sulject were: 'Pour laccomplissement et consommation dictlluy. elle (Madame Eleonor) sera menee en France, au meme instant de lia delivrance de mes dits seigneurs,' etc. 
French, and another boat the Spanish, bank of the river 'Audaie' (Aude), dividing the realms, the French boat laden with 'crowns of the Sun,' the Spanish with Leonora and the princes : an exchange of freights was eftected in the middle of the stream, and the queen and her stepsons were promptly landed on French territory. The war between reckless impulse and stearly calculation, in which the chief laurels had fallen to the latter, was now terminated, and I.eonora might be regarded as the symbol of reconciliation. She was not gifted with the capacity of her sisters Margaret and IIary, but she proved an amiable and exemplary consort. Her influence, however, was insufticient to inspire friendly feelings in place of the deep-seated antipathy which her husband entertained towards her brother.

Henry was not without hope that, peace secured, the emperor might become so far softened as to consent to Katharine's withdrawal into religious seclusion. The hope was delusive. Katharine remained inflexible as ever. Charles, however much disposed to humour Henry in minor points, was bound by the honour of his family and his own, and by express promise, to concede nothing in contradiction to the will of his aunt. It was even possible, on the other hand, that Francis, when by the help of English gold he had recovered the dauphin and the Duke of Orleans, might become so far reconciled to the emperor as even to cool somewhat in his devotion to his 'brother' of England. It could hardly be concluded, therefore, that the peace, whatever blessings it might bring in its train to Europe, anc especially to the two foremost of the principal contractors, ${ }^{*}$ who, doffing their armour, were to don the robes of peace, had in any degree brightened Henry`s matrimonial prospects.

The outlook grew darker, when intelligence arrived from Rome that the Treaty of Cambray (August 5) had been preceded by the declaration at Barcelona of perpetual peace between the pope and the emperor. By the secret clauses of the Barcelona compact, ratified by the double-dealing

* There were comprised, as 'principal contractors,' the pope. and the Kings of Hungary, England, Poland, Denmark, Portugal, and Scotland. -Rymer, vi., pp. 12y-13ij. 
Clement in June, Charles, on his part, engaged to subdue Florence and restore it to the Medici, and to wed his natural danghter Margaret to Alessandro, l)uke of Penna, the pope's nephew. Clement, on his part, bound himself to keep the French out of Italy, and to comply with the emperor's will in the divorce cause. The extent of the pontiff's duplicity could scarcely have been divined by the King of England; but the Barcelona agreement was in itself a significant token that the pontiff at length distinctly recognised the total discomfiture of the French, and without any farther real hesitation linked his fortunes definitively with those of Charles.

It may be observed that the year 1529 was very memorable both politically and religiously. Charles crossed from Barcelona to Italy July 27 ; the 'l'reaty of ('ambray was concluded, in the first week of August; the breach between the papacy and the King of England widened into a 'tixed gulf'; in Germany the Protestant banner was unfurled at the liet of spires, in the spring; the two sections of its adherents attempted a reconciliation under its folds at Marburg in the autumn.

The pontifical prorogation of the divorce suit seemed to put the final crown upon the imperial trinmph. A brief, dated July 19, expressed to Wolsey ('lement's deep regret that he had been compelled to advolie the matrimonial cause, and added the anxious hope that the cardinal, taking into consideration for how long a time the pontiff had succeeded in delaying the revocation, would use his best eftorts to retain his sovereign in faithful attachment to the holy see. The divorce cause had, in fact, been revoked as early as July 13. Nor was it to any eftectnal purpose that an earnest letter from Wolsey (July $2 \bar{\tau}$ ), when he was as yet only anticipating the decisive blow with gloomy apprehension, instilled the warning: 'Campegrio unites with me to urge the pope, if it (the arlvocation) must be granted, to qualify it; for if the king be eited to appear in person, or by proxy, and his prerogative be interfered with, none of his subjects will tolerate it; or if he appears in Italy, it will be at the head of a formidable army. If, however, the advocation is merely intended to close my hands, without preventing the king from taking any other 
remedy, it may be allowed to pass. A citation of the king to Rome, or threat of excommunication is no more tolerable than the whole loss of the king's dignity. If, therefore, the Pope has granted any such advocation, it must be revoked.'*

Fruitless were the best grounded remonstrances. The advocation was followed by a suspension of the king's cause till Christmas. Then the cause was suspended from Christmas till Easter; and whilst the suit was pending, the king was inhibited from taking another wife. So much deference was accorded to his regal authority that the emperor and pontift" conceded--with Katharine's assent†-that the 'letter citatorial' should not be exhibited, but only the brief addressed to Wolsey. The legates issued a public notification (September 11) of the expiry of their office.

Yet even now Clement was too insincere and too timid to shut the door absolutely upon Henry's claims. Together with the surpension had come the promise that in three months the pope would 'pronounce a sentence of divorce,' and give license for a second marriage. But Henry was in no mood to be longer cajoled. He replied that he 'regarded with grief and wonder the incredible confusion which had arisen. If the pope could relax divine laws at his pleasure, he must have as much power over human laws. No reliance could be placed on his promises. His own dignity as King of England had not been consulted.'

To Clement Campeggio boasted that neither by fair means nor fonl had the king and his court been able to render him the tool of their purposes. He took his leave of Henry after a brief delay; and October 5, with no reluctance, quitted London. Two days later, the state of the roads being deplorably bad, he succeeded in getting as far as Canterbury. At Iover the watch demanded to examine his trunks, despite his passport; and on his refusing to yield the keys, broke open his locks, and ransacked his coffers. But no Commission Decretal could be discovered - that had been ashes long ago;

* B. iv., part iii., 5797.

+ This lenity of Katharine Henry proposed to use against her, if she should change her mind. He wrote to Gardiner (Neptember 21, 152!). that he hoped 'this, her act, done before you and Campeggio, may prevent her from proceeding at Rome, or gaining any citation hereafter,' if she 'should retract.' The citation to Rome was extremely offensive to him.-B. iv., part iii., 5936. 
no epistles from the pope could be found. In many chests there were only 'old hosen, old eoats, and such vile stuff.'

Campeggio made his complaint to Henry of the scant respect shown to his legatine authority, and received a characteristic answer: 'As to your legateship, no wrong has been done by me or mine, seeing that your authority only extended so far as to the termination of my cause.... I wonder that you are so ignorant of the laws of this kingdom that you are not afraid to make use of the title of "legate," when it beeame defunct, seeing that you are a bishop here, and so bound by the most solemn obligations to observe and respect my royal dignity, jurisdiction, and authority.' A rough apology for Campeggio's rude treatment by the watch followed: 'You may infer from it,' the king added, 'that my subjects are not very well pleased that my cause has come to no better conclusion.' There can be no doubt that the policy and procedure of Rome, crafty, false, insolent, and abjectly subservient to the emperor, was beginning to disgust the English people, and to range on the king's side many before nentral, or even disaffected to his eause.

Thus ended the most eelebrated act in the long drama of that wearisome controversy with the Vatican, on issues connected with which hung the destinies of our Church and nation. The self-stultification of the legates at Blackfriars had been displayed in sharp contrast to the prompt suecess of the ladies at Cambray. Margaret was only spared one year longer in the post which she had filled so well. To Europe her legacy was peace. Clement might felicitate himself on the shrewdness and fidelity of Campegrio; but it was very humiliating to him in the face of Christentom that he had sacrifieed his word and the dignity and stability of the holy see to his personal safety and the interests of his family. Of all the chief actors the least contented was the ablest of all, whom Erasmus styled 'the great Cardinal of England.' IIampered in his clear-sighted policy by his reticent, wily colleagne, his love to his sovereign, his love to his Church, frustrated by Rome's treachery, a slave to cireumstances which had overmatched his genius-little else remained to Wolsey than to anticipate with trembling solicitude the inevitable and rapid shipwreck of all his greatness. 


\section{V.-NEW MINISTERS.}

THE fortunes of Wolsey only for a short time seemed to waver in the balance. At Grafton, in Northamptonshire, whither the two cardinals journeyed (Neptember 14) and presented themselves before the king on Sunday, September 19-for Henry and Anne were there enjoying the 'grease (stag-hunting) season' in rides and pastimes-Wolsey found that no apartment had been prepared for his own especial use, and he was able to obtain accommodation only through the kind offices of Henry Norris. Yet he was favoured with a private audience, which before he had solicited through Gardiner in vain. The king previously, in reply to his solicitation, had requested him to commit what he had to say to letter. He now knelt before his sovereign in the chamber of presence, "under the cloth of estate,' and Henry lifted him up by both arms, and led him by the hands to a great window, and, 'causing him to be covered,' held 'long and earnest' conficlential communication with him.

The courtiers, less well-disposed to the cardinal than was their monarch, turned curious and perhaps distrustful eyes towards the king and his old minister. Henry was observed to pluck out of his bosom some writing, apparently a letter, and was overheard, in answer to some statement of Wolsey, to inquire in kingly tones: "How can that be? Is not this your hand?' It has been conjectured that the writing in question was a secret and traitorous letter of Wolsey to Clement, which, unearthed by Bryan at Rome, had been filched from him by his cousin Anne, and by her placed in the king's hands. To this conjecture Shakspere has helped to give currency.* No 
such letter, however, has ever seen public light, and the affair still remains a mystery at the present day, when so much long involved in doubt has been rendered clear.

lut whatever the writing may have been, it cannot have served to substantiate any very weighty charge; for after a while the king appeared fairly satisfied with the cardinal's explanations, and said to him: "Ny lord, go to your dinner. ... After dinner I will resort to you again, and then we will commune further with you in this matter.' It was ominous that at dinner Norfolk could not forbear downright insult, but even hinted to the cardinal the royal intention to banish him to York. After dinner the king and the cardinal eonversed together for a long time, not only seriously, but amicably. The Council sat on September 23, when it was remarked that 'Suffolk, Norfolk, Tuke (Sir Bryan), and Stevins (Gardiner) showed as much observance to the cardinal as before.' The correspondent who furnished this intelligence to Crumwell added: 'What they bear in their hearts I know not.' It was considered to bode no good to Wolsey at this juncture that the legates were forbidden to move about the country with a large retinue, or with crosses.

But shortly afterwards, even before Campeggio had quitted London, the prospeets of the cardinal allowed no longer room for speculation or hesitation. The imperious favourite's forfeiture of place and power was inevitable beyond doubt. The French ambassador wrote home (October 4$)$, with much regret: 'The cardinal's ruin is certain (s'en ea totulement); I see no ehance to the contrary.' 'The force of the current that bore him down was overwhelming. Anne and her partisans hated him. The larly was heard to say that 'it would eost her a good twenty thousand erowns before she had entirely done with

I wit to his Holiness. Nay, then, farewell !

I have touched the bighest point of all my greatnes 3 ;

And from that full meridian of my glory

I haste now to my setting; I shall fall

Like a bright exhalation in the evening,

And no man see me more.'

-King Henry III., act iii., scene 2.

'Anne Boleyn is said by ber enemies to have stolen this letter from Bryan, and to have given it to the king.' - Mackintosh ii, p. 165. Herbert, 1:3-4. 
him,' but that she did not grudge the expense." The friends of Katharine on this one point were in thorough agreement with Anne's faction. Aspiring courtiers and politicians were building their eager hopes of preferment on his ruin. Norfolk and Suffolk detested the cardinal, and were greedy of his power and influence in the State.

The catastrophe was deferred but for a brief space. The king directed the Attorney-General (Christopher Hales) to 'sue out a writ of premunire' (October 9) against Wolsey in the Court of King's Bench. The indictment stated that he had 'procured and published' Bulls from Clement, 'contrary to the statute of 16 Ric. II., c. 5,' and had exercised the oftice of legate. Towards the close of the month the cause was tried. By his attorneys (Scuse and Genney) Wolsey pleaded that he "knew not the obtaining Bulls to be in contempt or prejudice of the king, or against any statute of provisors.' The accused minister, techuically guilty, was morally innocent. Than Henry's conduct nothing can be conceived more abjectly dishonourable. For in the matter of the legateship, whatever had been done had been sanctioned by the royal cognizance and approval. 'The king's highness,' Wolsey conld answer to the judges sent to him purposely to examine him, 'knoweth right well whether I have offended his majesty or no in using of my prerogative legatine, for the which ye have me indited. Notwithstanding I have the king's license in my coffers, under his hand and broad seal, for exercising and using the authority thereof in the largest wise,' etc..$_{+}^{+}$But, with wary foresight, his papers had been at once seized, so that it was out of his power to produce what would have been his complete exculpation. If, however, he could have produced the royal license, a selfwilled, despotic monarch such as Henry would thereby have been personally alienated, which would have been even an aggravation of the fallen favourite's misfortunes. For the king himself was in heart less unfriendly than the malicious courtiers, who buzzed their calumnies about the royal ears.

From the beginning of his troubles Wolsey met the frowns of the Court with the deep humility and absolute submission

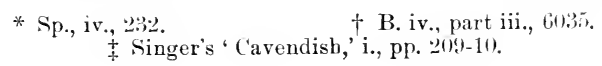


which alone promised any mitigation of his calamity. He threw himself at the king's feet and implored the royal mercy. He was 'entirely,' he declared, 'in his obedience.' 'Next unto God,' he professerl in his often-quoted letter,** I covet nothing so much in this world as your favour and forgiveness. The remembrance of my folly, with the sharp sword of your displeasure, have so penetrated my heart that I cannot but lamentably cry and say, S'nficit: nunc contine, piissime rex, munum turm. Beati misericories, quia ipsi misericurdiam consequentur, which that I may obtain I shall not cease to pray, as your most prostrate poor chaplain, creature, and bedesman, T. Car ${ }^{\text {lis }}$ Ebor., miserrimus.'

By an Italian servant, the only one who remained faithful to him, Wolsey entreated the French ambassador to induce Francis to address Henry in his behalf, by their "fraternal affection,' not to take up suddenly any 'bad impressions against those whom the world has once seen in such great authority, and whom he has employed as instrumental in the present amity of the two sovereigns so renowned throughout Christendom.' Francis sent John Joachim, the cardinal's former associate in diplomatic intrigue, to the English Court, the reinstatement of Wolsey in his royal master's good graces being a scarcely-disguised part of his errand. 'The French,' wrote Chapuys to the emperor, "would spare no means to reinstate the cardinal: for, whatever they pretend, they have no confidence in the I)uke of Norfolk.' Even the emperor himself, gratified by the Universal P'eace, which was attributed in large measure to Wolsey's efforts and influence, spoke of him in terms of commiseration, and intimated an intention of arddressing to him a friendly letter. But public services, however eminent, weighed lightly in the scale against rancorous domestic animosities, and the sympathy of foreign potentates was too feeble a prop to withstand the fierce continuous stream of courtly and popular antagonism.

His rivals at Court still feared him. It was apprehended that his long experience and unequalled talent would be

* Written, Brewer conjectures, the very evening of the day on which Wolsey sat in the Chancery for the last time, or the day before.-B. iv., Intro., p. dxxii. ; iv., part iii, 5999. 
deplorably missed, and the engine of government prove at fault through the lack of what he was wont to call his "poor judgment.' For some time he had all but monopolized functions, great and small, of infinite variety in Church and State, and no multiplicity or complication of business had been found a burden beyond his powers. The king only ' coveted his goods ;' he had no personal dislike to the friend of his boyhood. Renewed intercourse between the royal master and the old favourite was thus dreaded, and it was determined by the hostile courtiers, with Anne at their head, to allow no scope to Wolsey for the play of his insinuating address.* With womanly tact, but with firm and resolute hand, Anne kept the specious cardinal at a distance. Wolsey well knew the witchery wherewith she spell-bound his sovereign, and spoke of her as his ' continual serpentine enemy about the king.' Sometimes he would allude to her as the 'night-crow.'

Of the councillors now, by the removal of the most capable statesman of the age, brought forward to the front rank, the Duke of Suffolk, Charles Brandon, Henry's brother-in-law, was Marshal of England. He had claims on the house of Lancaster, as the son of Sir William Brandon, standard-bearer on Bosworth Field, who had been struck down and slain in Richard's furious onset to measure swords in personal combat with his rival, Richmond. Suffolk was of big bone, and splendid muscle ; a successful gamester, but of shallow brains ; brilliant in the tourney; an efficient soldier of Flodden renown; as a general, worse than impotent. The low morality of the day found in him an expressive personal representative. $\dagger$

* Such was the courage and ambition of the Cardinal. Chapuys in. formed the Emperol that he would not fail to try to get back into favour 'if he saw a favourable opportunity, and this was not unlikely, if the king should require his advice. Then the duke (Norfolk) began to swear very loudly that rather than suffer this he would eat him up alive. To prevent such a contingency the Cardinal has been forbidden to approach the cov $t$ within seven miles.'-B. iv., part iii., 61!99.

$\dagger$ Sir Charles Brandon 'made a contract of matrimony with a gentle woman called Mrs. Anne Brown, and before any solemnization of that marriage, not only had a daughter by her, which after was married to the Lord Powis, but also brake promise with her, and married the lady Mortimer. Which marriage the said Mrs. Anne Browne judicially accused to be unlawful, for that the said Sir Charles Brandon had made a precontract with her, etc., which being duly proved, sentence of divorce between the said Sir Charles and the lady Mortymer was given, and he 
To the fair sex he was an object of admiration, although now in his forty-ninth year. Having been sent into France, to eseort home the youthful widow of Louis, he had suceumbed to the too potent temptation, and wedded her at Clugny; and thus broke the promise which her brother had exacted, Franeis himself countenancing the perjured lover by his presence at the ceremony.

The dukedom of Norfolk had passed to the Howardswhose earliest known ancestor was a judge in Edward I.'s reign-through the marriage of Sir Robert Howard, the first duke's father, with the sister and eo-heir of Thomas Nowbray -who had died 1475-the last duke of the ancient line. Thomas, the present representative of the new line, was intermediate between his father Thomas, the victor of Flodden, who had died 1524, and his son Henry, Lord surrey, the aceomplished ill-fated poet. This second duke of the restored Howard line, was Treasurer of England, and High Admiral. In capacity he was Suffolk's superior; in wealth inferior to him, his yearly revenues being computed at 20,000 dueats. He was three years younger. In personal appearance he was quite unlike the other duke; for he was short of stature, grim

married solemnly the sail Mrs. Anne Browne, at which marriage all the nobility were present, and did honour it : and after hat by her another danghter, who was married to the lord Monteagle. After this the said Mrs. Anne Brown continued with him all her life as his wife. and died his wife, without impeachment of that marriage. After whose death King Henry, having the said Sir Charles Brandon in great favour, meant he should for his better preferment have married the lady Lisle, being a young miden and an inheritor. Whereupon the said sir Charles was created Viscomint Lisle; but that marrage, by reason of her youth, took no place. After this he was created Duke of Sinfolk; and Lewys, the French king, dying and leaving the said Lady Mary, King Ifenry the Seventh's daughter, a widow, the said duke ('harles heing sent into France for her, with the consent of King Henry the Eighth, manied her twice, first secretly in France, and openly here in England, ite.-13. iv., part iii., 5xist, note, from a MS. in Lord Salisbury's possession.

'The Freneb Queen' died June :23, 15:33. 'The Septemler following Suffolk married Katharine Willoughby, who hat heen lmomised to bis son, a lad ten years of agr. The king give the duke to defray the expense of the burial of the French Qneen the fruits of Ely bishoprie, then vacant.B. vi., 720, 16ri9. Her dower had been :30,000 ducats, which suffolk lost by her death.- Ven., iv., $12 \%$.

Suffolk had ever' a keen eye to his peeuniary interests. "My lord of Suffolk,' it was said of him, 'is loth to let fall a noble unless be can take up a royal for it.'-13, vi., 6i:?. 
of visage, of dark complexion. In the Venetian despatches he goes under the description of 'the small man with dark hair.' Ambition, jealousy, vanity, harshness, dissimulation stamped his character. Yet, adept as he thought himself in the wiles of intrigue, an impulsive, hasty temper often thwarted the success of his artifices, and made him ' a bad dissembler.' His duchess, the sister of the decapitated Buckingham, remained true through all vicissitudes to Katharine and Rome.* But her coarse husband preferred the society of Bess Holland. So little disposed was Norfolk to favour the Reformation, that it was one of his vaunts that he had never read a syllable of the New Testament in English, and never would.

It seemed impossible that such men as the 'two dukes' should long fill, with tolerable satisfaction to the royal mind, the gap caused by the humiliation of a real statesman. Wolsey's disgrace threw much unwonted labour on Henry: less time had to be devoted to sport and more to business. $\dagger$ But a man of very different calibre had been brought forward in the progress of events, trained like Crumwell and Bonner, under the cardinal's shrewd eye. This was Stephen Gardiner, who had returned from his long embassy; and having acquitted himself with rare ability, enjoyed the prestige of proved address in diplomacy, the path, in the England of that age, to honour and promotion. Appointed the king's chief secretary, July 28, 1529, Wolsey's 'half of myself' soon became the king's right hand. The patron's ruin was a stepping-stone to the protégés advancement; for when Wolsey was forced to resign Winchester, Gardiner obtained that see. An amusing caricature by Ponet, his successor in the bishopric of Winchester, has described Gardiner's person; his 'swart colour, hanging loke, frowning brows, deep-set eyes, hooked nose, sparowe (small) mouth,' and long feet, or 'talauntes ' (talons) — as Ponet calls them—which he 'scarcely

* Agnes, the victor of Flodden's willow, the 'old duchess,' took precedenee of the present duehess by Anne Boleyn's express determination. John Howard ('Jockey of Norfolk') was created Duke of Norfolk by Richard III., June 28, 148:3, He fell on Bosworth Field. His son Thomas was attainted, but refusing to join in the rebellion of the Earl of Lincoln, was created Earl of Surrey 1489 ; was victor of Flodden, September, 1513; and Duke of Norfolk, February, 1514.

† Sp., iv., 42.2 . 
suftered to touch the stones.' Subsequently the notorious Marian persecutor, Gardiner was at this time high in Anne's favour, and apparently zealous in furthering her matrimonial ambition.

To the mention of the principal ministers on Wolsey's removal from court, it will not be inappropriate to add the interesting figure of a foreign ambassador--to whom history owes much-who came upon the scene just about this crisis. Eustace Chapuys (Shalispere's 'Capucius'), was the successor to Don Inigo IIendoza (September, 1529), as imperial ambassador. He was not, like his predecessor, of Spanish blue blood; but was, it would seem, a Swiss by birth. His lively despatches place English habits and characters before the reader with vivid minuteness. A little interesting domestie fragment appears in his account of a December afternoon spent, a few months subsequently to his arrival, at the mansion of Torfolk-who was strongly imperialist in his political sympathies, and enjoying an annual pension from Charles of one thousand ducats, was disposed to be civil to his ambassador. Chapuys had been invited by the duke to supper. On entering the room he found his host engaged with some friends at the card-table. When the game of la premiere was over, the duke rose from the gaming-table, and giving his hand to his guest, led him in to supper.

While at the supper-table, the duke showed Chapuys a piece of Latin prose, written by his eldest son, the future poet, then a lad of eleven years; and, with paternal pride, inquired the ambassador's opinion of its merits. Certainly the judgment of Chapuys camnot have been worth much, unless his skill in Latin exceeded his skill in French. But it is interesting to have this early glimpse of the future poet, to whom we owe much: for Henry Howard had a true taste; he left French models to his friend Wyat, and followed the Italian; he purified our vocabulary, corrected our spelling, and framed our blank verse; besides immortalizing Geraldine. 'The king has entrusted to me,' said Norfolk, 'the education of the Duke of Richmond, to whom my son mal become in time preceptor and tutor.' The duke was so polite as to escort his guest back a mile and a half to his lorlging: 'and in the walk he told 
me,' wrote Chapuys to the emperor, that 'according to the uses of this country the king had sold him a very rich damsel to be his son's wife.' The ambassador remonstrated, remarking, "Your son would hardly consent to such a blameworthy act as buying a wife, when he could find plenty of nobler damsels willing to buy him.' ${ }^{\text {, }}$

As regards ecclesiastical dignities, important changes followed on Wolsey's disgrace. T'unstal was translated from the see of London to that of 1)urham; the cardinal having in vain begged the bishopric of Durham for his own son, Tom Winter, at that time a lad engaged in learning good letters and the French language at Paris. For to be conversant with French was in that age a far more rare accomplishment than at present; and it was an accomplishment which the cardinal had found very serviceable in his own career. Tom Winter was already Dean of Wells and Archdeacon of Jork and Richmond, of Suftolk and Norfolk, besides other preferments. The posts were sinecures; or what slight duties they might involve could be easily performed by deputy. The profits the father appropriated to his own use, for the most part; since his magnificent style of living - much admired at Rome-and the founding of Cardinal College were an exhaustive drain even on lis extraordinary resources, computed by Falier to reach the annual total of 150,000 ducats, without including presents in this estimate. $\dagger$

The metropolitan see Tunstal relinquished to Stokesley, or 'Dr. Stockler,' as foreigners called him; the privy seal he resigned to Wiltshire. Stokesley had won promotion by his able advocacy of Henry's divorce cause. He was a worse man, and a more cruel persecutor, than his predecessor Tunstal. On Wolsey's decease, fourteen months later, York would have been conferred, it was rumoured, on Reginald Pole, son to the Plantagenet Margaret Lady Salisbury, the Princess Mary's governess, had Pole been willing to uphold the king's cause in the divorce question; but such a condition he found too burdensome for a sensitive conscience. The archiepiscopal

* Sp., iv., 18, 228 .

+ Ven., iv., 694. The expenses of the king for army, buildings, ambissadors, etc., were estimated at only $440,0(0)$ ducats. 
see, therefore, was bestowed on Edward Lee, who had done good diplomatical service, in company with Ghinucci, in Spain. It was argued that the king foresaw that he should require all the support he could procure in Parliament, by the see being filled more quickly than the royal wont. For it had been Henry's custom to wait a full twelvemonth before nominating to a vacancy, in order to reeeive himself in the interim the emoluments, and distribute the dependent patronage, which was attended with valuable douceurs. This brief account, however, has forestalled events, and interrupted the narrative, to which it is necessary now to return.

The first day of term $W^{\circ}$ olsey, assuming a bold front, proceeded with his usual train to Westminster Hall, and took his seat as Chancellor. His enemies were immediately upon the alert. The dukes shortly afterwards came to York Place, and in the king's name demanded the great seal. Wolsey required the royal mandate, and upon this being afterwards exhibited, he surrendered the seal. His otficial decease as Lord Chancellor took place amid the grandeur and pomp which had lon's surrounded him; for the surrender was made in the gilt chamber adjoining his gallery.* His face had lost 'half its cuntomary vigour.' 'The very same day the French ambassador visited him and found him quite disconsolate, 'ready to give up everything to his shirt, and go and live in a hermitage, if only the king will not keep him in disfavour.'

Five days later, the intelligence was transmitted to the French court, "While writing, I have heard that Wolsey has just been put out of his house, and all his goods taken into the king's hands. . . The Duke of Norfolk is made ehief of the Council, Suftolk acting in his absence; and, at the head of all, Mademoiselle Amne. It is not known yet who will have the seal. I expect the priests will never have it again.'

Before leaving the sumptuous lork Place, Wolsey made with his own hand, as he was commanded-' that nothing

* 'In quadam alta camera prope deambulatorium suum.'-Rymer, vi., p. 238 .

The great seal was surrendered to the two dnkes, Sunday, October 17, at is p.m., "in the presence of Sir Wm. Fitz. William, John Tayler, and stephen' (iardiner.'-B. iv.. part iii., 60.25. 
might be forgotten'-an inventory of his furniture and goods; the tapestry of his gallery hung with cloth of gold, his rich copes, 'the richest ever seen in England,' provided for his two Cardinal colleges, and the rest of his magnificent decorations. His gold and silver utensils, and his splendid imitation plate were piled upon tables set on trestles, in the two lofty rooms adjoining his gallery. His silks, velvets and fine linen were arranged in imposing order. To dazzle and gladden his royal master's eye seemed to aftord him a momentary gratification. On October 24, Henry, with Anne and her stepmother, and a gentleman of the bousehold, came by barge from Greenwich, and surveyed the gorgeous show, which, it was reported, even exceeled the royal expectations in splendour and value* Ere this, the cardinal himself, by his master's command, had retired from Westminster to Asher (Esher), to an ill-furnished, comfortless dwelling-house, appertaining to his see of Winchester.

Proceeding to the water-side, with only one cross borne before him, he 'took his barge at his privy stairs' for Putney. His departure was witnessed by thousands of men and women, 'waffeting up and down in Thames,' as the scene has been described by Cavendish, an eye-witness. The fall of the English Sejanus, who had been so long drunk with prosperity, but was now at last sobered and humbled, the spoiled court favourite, and all-engrossing administrator, was almost universally welcome. For the most part, it was a moment of disappointment to the populace, when the barge carrying the dejected cardinal and his retinue began to be moved up the stream. It would have pleased tens of thousands to see the discarded court minion rowed towards the Tower, to be landed at the Traitor's Gate.

Disembarked at Putney, the cardinal mounted his mule, his attendants their horses, and when the company had made progress 'not past the length of a pair of garden butts,' relates Cavendish, Norris came riding down the hill, and saluted Wolsey with 'comfortable words' from his grace's highness. The cardinal was deeply moved. Alighting from his mule, he knelt down in the dirt upon both his knees, and held up his

$$
\text { * Sp., iv., } 194 .
$$


hands for joy. His velvet eap he pulled down from his head, breaking the laces in his haste, and so knelt bare-headed. In his profuse gratitude, he gave his cross as a most precious gift to Norris-'a picce of the holy (ross '-whieh he had been aceustomed to wear about his neek next his skin, and together with it his ehain of gold. To the king himself he sent as a gift, in token of his thanks and devotion, his poor fool, Williams, or Pateh, the latter the professional name. The fool, more faithful than many better and wiser, 'took on' at leaving his patron, and could only be torn away by the strength of six tall yeomen. Wolsey in his splendour had sometimes smiled at his jests. 'For a nobleman's pleasure,' said he, 'the fool is worth a thousand pounds.' Williams was passed by Henry, who had himself already a fool of the name of Sexten, to the service of Anne.

For Henry's ostentatious eompassion various reasons have been assigned. Were there any stirrings of generosity towards one so exalted, now fallen; so cherished, now abandoned? Or did the king inagine that the cardinal might yet be of service in his divoree ease? Or was avarice at the bottom of the royal relentings? Was it supposed that Wolsey had haply more treasures to diselose? Or was his assistance eraved for the transference to the crown of the eoveted York Place, or of Tittenhanger, a residence sometimes resorted to by royalty, and belonging to St. Albans? That some pecuniary eonsideration quickened the king's pity is the most probable conjecture; and it is eorroborated by the recollection that there was a palpable motive for the preservation of Wolsey's life, inasmuch as his French pension of 25,000 erowns would now be appropriated, of eourse, by his master.

The great seal, offered to and declined by Warham, was coinmitted, Monday, October 2.), to Sir Thomas More, $†$ on the

* Privy purse expenses, December, 1729: 'Doublet of worsted, hosen, and sircenet for Sexten, the fool, 31s. 10d. 1sth. To John Emson, keeper of the king's fool, 15s. 4d. . . A perwyke for Sexten, the king s fool, 211..'-13. v., 1. 7.77.

$\dagger$ The emoluments were not great.

'Wilrant to allow Sir Thomas More, as lord ehaneellor, the yearly sum of 214215 , from Oetoher 25,21 Henry VIII. ; and for his attendance in the star Chamber, 200 a year.' By the ehief butler, 164 a year to purchase 12 tons of wine: by the keeper of the great wardrobe, $£ 16$ a year for wax, were also allowed.-B. iv., part iii., 9079. 
express understanding that in the discharge of the important functions of the post regard should be had "first to God, and after God to the king.' Such was 'the first lesson the king gave me,' More would repeat with pleasure, 'on coming to his service.'

A layman again, after the precedents of earlier times-such as the popular Parynge, and the laborious Knyvet, in the reign of Edward III.--Lord Chancellor of England: No layman had been chancellor for tive-and-forty years. Before that time even soldiers as well as lawyers had been chancellors. But they had been appointed in spite of their being laymen. Now, it was a recommendation to the high oftice in Nlore's case, that he vers a layman. Yet was he, although a layman in fact, a bigoted Roman ecclesiastic in soul. And thus, those who were warm on the side of Rome exulted. 'Every one,' wrote Chapuys to the emperor, 'is delighted at his promotion, because he is an upright and learned man, and a good servant of the queen.' Erasmus sent his congratulations, but was careful to observe that he did 'not congratulate More so much as England and the king.'

The cardinal had been 'disevangelized,' St. Lnke's Day (October 18). The next day Norfolk and Suffolk appeared in the Star Chamber, and declared the causes of Wolsey's deprivation, and were appointed to administer justice in his stead. Eight days later Wolsey was 'judicially and definitely condemnerl by the council;* was declared a 'rebel,' guilty of high treason: was deposed from his dignities: all his goods confiscated, and he himself sentenced to prison. A private communication, however, was vouchsafed to him, that on his ample confession, and surrender of everything which he possessed, a pardon would be granted him by the king, and he would be delivered from all danger of the laws.

He was willing to submit to both these conditions. $\mathrm{He}$ acknowledged in legal indenture that, by virtue of his legatine authority, he had vexed unlawfully the greater number of the prelates of the realm and other subjects of the king; and he therefore prayed his highness, 'as some atonement, to take into his hand all his temporal posses-

$$
\text { * Sp., iv., } 194 .
$$


sions, pensions and benefices.' Both by word and document Wolsey's abject submission was now eomplete. The king, on his part, seemed satisfied, and sent Sir John Russell to the prostrate cardinal with 'comfortable assuranees,'* which were weleomed with all due submissive thankfulness.

* In reply Wolsey entreated that 'as soon as it will stand with your honour, it may be openly known to my poor friends and servants that you have forgiven me mine offences, etc. 'This letter to Heury has no date. Brewer assigns October 24 to it. 


\section{VI.-THE REFORMIING PARLIAMENT.}

A Parlianent had been summoned - another significant indication that England was on the threshold of a new era. To resort to the deliberate judgment of the nation was to proclaim Wolsey's policy at an end, and his overthrow final. Bright hopes at, once began to be entertained of manifold reforms, especially of the amendment of clerical abuses and exactions, the burden of which was increasingly felt to be galling and insupportable. Soon members of 'the upper and nether house,' leaving their country abodes and pursuits, were flocking to London with a new alacrity, notwithstanding the hindrance of abominable roads, the ruts, frequently some feet in depth, and 'the little security against robbers.' Attendance in Parliament in that age could be countermanded by the sovereign, or else was actually compulsory; but no such spur as compulsion was required at the present crisis. It seemed as if the chief persons of the nation from the farthest and nearest parts were converging, impelled by common and exciting motives, to the IIetropolis. As for the king, he knew and felt the necessity of having Parliament on his side in the impending struggle. He was beginning to realize more and more distinctly the likelibood of his being forced, erclong-to quote his own words-to 'proclaim the pope a heretic and marry whom he wouldl.'

The Parliament met at Blackfriars, Wednesday, November 3 , when the new lord chancellor opened the proceedings in what was commonly pronounced an 'eloquent oration'which Chapuys, however, criticized as 'rather diffuse.' The king was present in garb of erimson lined with ermine, the members of Parliament were attired in scarlet cloth. Towards the monarch there was no stint on More's part of the fulsome 
panegyric then in vogue. The chancellor dilated in terms of high approval on the peace of Christendom, which, he said, the king desired to consolidate. He spoke of the royal purpose to reform justice, with a view to which the eardinal, as ehief defaulter, had just been tried and eondemned. But 'of all matters of state,' he went on to say, 'those concerning ecelesiastics most need reform.' This was the burden of the speech-reform, especially ecelesiastical reform. Aecording to Hall,* referring to the king, after the custom of the times, as the 'shepherd,' his subjects as his 'flock,' he likened Wolsey to the 'great wether, of late fallen,' who 'so craftily, so scabbedly, yea, and so untruly juggled with the ling.' The king 'saw him, yea, and saw through him,' and had administered a 'gentle correction.'

Such words certainly appear ineonsistent with the speech delivered by More when he first took his seat in the Chancery. The very day after his appointment (Oetober 26) he was led between the two dukes up Westminster Hall to the stone chamber, at the south-west corner, where were 'the marble table and marble chair ;' and having listened to an address to the bystanders on his elevation to office from the Duke of Norfolk, he, in reply, with a modesty which cannot have been altogether mock-humility, 'disabled himself as ummeet for that room, wherein, considering how wise and honourable a prelate had lately before taken so great a fall, he said he had no cause thereof to rejoice.' Such words carry in them a strange sound, inasmuch as only eight days later More descanted before the king, as has been narrated, on the cardinal's gross mistoings. 'Divers laws,' he said-according to Hall-were made now by long continuanee of time and mutation of things very insufficient and imperfect, and also by the frail condition of man, divers new enormities were sprung amongst the people, for the which no law was as yet made to reform the same, which was the very eause why, at that time, the king had summoned his high court of l'arliament.' According to other accounts he censured the eardinal's administration of justice, as well as eensured the blazon of his ams, whereby he had profoundly oftended a proud * Hallis 'Chronicle' (1 1 sot r p. itit, ete. 
nobility and haughty monarch. The remarks in Parliament do not convey the impression that as Chancellor Wolsey had been a success, and equal to the demands of the times; and thus they run counter to the compliments lavished in the Chancery. More's words in the Chancery are given at some length by his great-grandson, Cresacre More, in his biography. His great-grandson represents More as praising Wolsey's 'admirable wit, prudence, authority and splendlour,' and makes him speak of his own succession to the same oftice as 'the lighting of a candle when the sun is down."* Roper's more brief narrative contains also the main points of the encomium on the deposed chancellor. After all, then, Iore himself, like other orators less high-principled, was not absolutely raised above the force of circumstances in his management of his ready tongue.

The plague was raging, a cause of panic not unusual in that unsanitary age. The Parliament, therefore--after the Commons had chosen Sir T. Audley their speaker-was adjourned to Westminster to meet there the following day. This adjournment suited the king's convenience, who, the day before Parliament met, had removed to, and established himself at York Place. This sumptuous memorial of the taste of the magnificent cardinal was taken plenary possession of by the crown without delay. But a shadow of justice was maintained. A house at York was made over to the see by the king in exchange. The transaction resembled Diomedes' exchange of armour with Glaucus, described by Homer.

This Parliament-' the most memorable that ever sat'which, atter such examples as the good Parliament and the unleurned Parliament, may with justice be named the reforming Parliament, holds its place at the very starting-point of modern life. It cleared the way for future progress, for those measures, whether affecting the connection of Church and State, or the relation of king and subjects, or the Parliamentary representation of the people, since enacted, on which the greatness and influence of our country-a morlel in its well-balanced constitution to the other powers of Europe-has been gradually and surely built up.

$$
\text { * See Hunter's 'Cresacre More's More,' p. } 176 .
$$


Parliament then was only the germ of what it has since become. The true material of efficiency was not absent; English sense and spirit, which transmitted through generations, and becoming more and more operative, would inevitably, in the course of events, enlarge the functions of the national representative assembly. At this period, after more than thirty years of civil war not long remote, the aristocracy were shattered, diminished, impoverished. The king's treasury had been replenished by forfeitures and confiscations, and a large proportion of the land had passed into royal possession. The bishops, too, and abbots were inclined to obsequious deference through the dread of events portentously looming in the not distant future. Henry was thus enabled to wield a sway yet more absolute than had been wielded by his maternal grandfather, Edward IV. With sagacious deceit, however, he determined to employ for arbitrary ends constitutional forms, like the Roman Cinsars. Parliament thus became the legal instrument for giving validity to his authoritative will. There was suddenly a great apparent change--more semblance, less reality of freedom. Parliament, which had always been regarded as a danger by Wolsey, now became a tool of the crown. At the present crisis, the House of Commons, the members in many instances chosen by court preference-and following in the house the instructions of the court*-was, to a considerable extent, in virtual sympathy with the policy: as well as under the rigid entrol, of a despotic and unyielding sovereign.

Shortly after the meeting of Parliament, it was taken in hand to draw up a petition to the king for the amendment of abuses, aceording to that humble form of oli times, which, abandoned under Henry YI., had been resumed under Edward IV. The petition lamented the great 'discord' which had arisen 'between spiritual and temporal persons' by the diffusion of 'heretical books in English printed abroad:' and, at the same time, frankly lamented 'the uncharitable demeanour of divers ordinaries in prosecutions before the spiritual courts.' Eeclesiastical abuses, everywhere rife, were described in general terms, lut with force and clearness. Laws of con* See B. iv., part iii, Appendix, $2: 38$. 
vocatiun inconsistent with the laws of the realm; poor men citer before spiritual courts without any accuser; laymen eited out of their dioceses; excessive fines for the probate of testaments; heavy exaction ' in taking of corpse-presents or mortuaries ;* sacraments and sacramentals administered for money; an inordinate number of judges, scribes, apparitors, etc., in the spiritual conrts, a cause of great delays and unjust fees; large sums clained by ordinaries for induction to benefices; promotions conferred on minors called 'nephews or kinsfolk, the spiritual ordinaries meanwhile detaining the fruits: priests, stewards to bishops or abbots; spiritual men keeping tan-houses and trafticking as merchants; priests of small learning holding ten or twelve benefices, and resident on none; others, well-learned, without benefice or exhibition; holy-days multiplied, and fruitful of abominable vices and idle and wanton sports; accused persons sent to ward on suppressed accusations, and no amends granted, if at length they be found innocent; subtle interrogatories in charges of heresy so framed as to entrap the simple. These, and such like evils, the petition averred, had produced 'marvellous disorder.' His faithful Commons humbly besought the king, as 'the only head, sovereign lored coml protector', to apply a reformation and remedy.

Thus did this Parliament take the lead with earnestness and decision in the task of ecclesiastical reform. The title which it accorded to the Crown, no doubt by inspiration from the Court, was that which subsequently, when the most important topics of the petition came to be discussed in Parliament, or before the king as umpire, was conferred by the deliberate resolve of the same Parliament, following willingly in the reluctant footprints of a brow-beaten Convocation. If the general statements of this petition be compared with statements and arguments in Tyndale's 'Obedience,' it will be seen that the translator was the true exponent of national convictions which he had himself, without doubt, borne some share in maturing.

* See B. iv., part iii., 6183. Mortuaries were oblations to the parish church on a death in a parish, enforced, according to Dean Hook, by a law of Canute. With the Commons' Petition (B. v., 11116) compare especially Tyndale, P.S., i., pp. 234-5 ; Latimer's 'Sermons,' P.S., p. $3 \times 3$. 
The king was bent on intimidating the clergy, in order to carry through to completion his own determined will. At this epoch, as well as in earlier times, the three estates of the realm were 'the spiritualty, the nobles, and the Commons,' who formed 'one body politic' under the king, their 'supreme imperial head and sovereign.' The nobles, thinned in number, enfeebled in jower, trembled before a monarch who had beheaded Edward Stafford, Duke of Buckingham-a monarch, moreover, to whom many of them owed heavy debts. It was observed by foreigners that the pope was hated in England, and that so, indeed, were the priests generally. The monasteries were commonly said to be too numerous by one-half. Thus, without the necessity of the smallest disguise, the king could talk openly of his intention to 'clip the claws' of the ecclesiastics and reform the (hurch. His project of ecclesiastical reform was quite acceptable to a considerable proportion of the Commons.

In confronting the united accusations and complaints of king, nobles, and Commons, the spirituality were not sustained by the courage which springs from a good conscience; and they were as little possessed of prudence as of courage in preparing against the dangers which threatened them on all sides. To throw the extortionate gains overboard and clear their imperilled ship, against which billows were surging and a furious storm was evidently brewing, was the one and only policy consistent with common sense. But the bishops and abbots were not inclined to submit to such sacrifices as were demanded, or, indeed, to accede to any reasonable compromise with their assailants. They seemed infatuated, and quite cowed by surrounding difficulties. Their ship was sinking under them: heart and hope had failed almost miversally both officers and crew at their utmost need.

Fisher alone gallantly stood forth, and with characteristic hardihood faced embittered opponents. But he attempted to defend what was really indefensible - if, at least, words which were rather an assault upon the adversaries of "their holy mother, the Catholic Chureh, which was about to be brought like a bondmaid into thraldom,' can be rightly called a defence.

$$
\text { * Sp., iv., } 228,232 .
$$


'My lords,' he said, 'you see daily what bills come hither from the Common House, and all is to the destruction of the Church.' 'Lutheranism,' he complained, 'is spreading itself amongst us.' He pointed to Germany and Bohemia as beacons uplifting a solemn light of warning to England and the world against heresy; and he imputed the still-growing heap of mischiefs to 'lack of faith.'* Such words were resented, ancl Audley, the Speaker, accused Fisher to the king of vilifying the Commons as tainted with heresy. The bishop was required to explain his meaning, and excused himself by saying that he "meant the doings of the Bohemians were for lack of faith.' Other bishops confirmed this explanation; but 'the blind excuse,' as the chronicler notes, 'pleased the Commons nothing at all.'

During the first session, however, only a few enactments in mitigation of ecclesiastical scandals were added to the Statute Book, $†$ and these, for the most part, could be easily evaded by provisos and dispensations. For the present, at least, it suited Henry's temper to threaten rather than strike, to alarm the clergy and deepen their submissiveness.

The Parliamentary impeachment of Wolsey commenced the first day of December. The Lords, headed by More, preferred against him forty-four articles of accusation-or rather fortythree, for the forty-fourth, according to custom, only enforced the preceding, and implored the king to make his fallen minister a righteous 'example.' These articles should be read side by side with the Commons' petition. The spirit of the two documents differs; their representations of the state of the Church substantially agree. The Commons assailed the ordinaries; the Lords singled out the 'bell-wether.' The clergy would even seem to have nursed the hope of possibly making Wolsey the scapegoat for what may, in regard to some cases, be called the scandalous delinquencies, and even enormities, of the clerical corporation. Fisher did not rise to exculpate him. The cardinal's silly pride, assumption of royal prerogatives, legatine pretensions, personal licentiousness in times not long remote, slandering of religious houses, and fatvouring of Lutheranism were all alleged, in order to prove him guilty of the crime of high treason. 
The modern reader smiles as he peruses the catalogue of charges, ${ }^{*}$ and is unable to resist the conclusion that the case against the humiliated statesman must have been very weak and frivolous. Personal motives, it is elear, largely intermingled their virulence. The articles in the main were founded upon Lord Darey's items of aceusation (who had personal grounds of enmity), which bear date July 1 ; with such certainty had Wolsey's fall been reekoned upon. But other influenees are traceable; and amongst these, glimpses of the humour which distinguished More are here and there pereeptible. To More the cardinal's poliey and eharaeter were alike distasteful; for the new chancellor was still not absolutely devoid of the liberal, popular sentiments which animate the ' Itopia, and his moral excellence was of the highest standard. Among the seventeen signatories-almost one-half of the temporal peers at that period-to the Act, which passed the Lords, oceur the names of 'T. Norfolk,' 'Char. Suftolk,' 'C. Shrewsbury,' 'H. Northumberland,' 'T. Darey,' and 'T. Roch ford.'

Proeedings against the unpopular, superseded minister followed in the House of Commons. It was proposed to disable him from restoration to his former posts of dignity and

* The following may be selected as samples:

'6. For having endaugercd the king's person, in that he, when be knew himself to have "the foul and eontagious disease of *** broken out upon him in divers places of his body, came daily to your Graee, rowning in your ear, and blowing upon your most noble Grace with his perilous and infeetive breath," and when he was bealed he made the king believe that it was only an imposthume in the head.'

-27. For making his son Winter spend 22,700 a year, which be takes to his own use, and gives him only f200 to live on.'

-3x. For committing to the Fleet one Sir John stanley, till he released a farm, which he held of the Abbot of Chester, to one Leghe of Adrington, who married one Larkes daughter, "which woman the said Cardinal kept, and had with her two children; wherenpon the said Sir John Stanley, upon displeasure taken in his heart, made himself monk in Westminster, and there died." '-B. iv., part iii., 6075.

Articles 6 and 38 have no eonnterpart in Darey's 'Articles,' who speaks, however, of Wolsey's 'presumptuous summoning and using of the king. adrancing his prodigal pawme (palm)? ete.-B. iv., part iii., 674!.

'A brief rencmbrance,' agaiust Wolsey, signed 'John Palsgrare,' amongst other things, says: "We have begm to encomrage the young gentlewomen of the realm to be our concubines, by the well marrying of Bussie Blont, whom we would yet by sleight have married much better that she is, and for that purpose changed her name.'-B. iv., part iii., 5750. 
trust, under the apprehension that Henry's eapricious temper might relent, and commiseration for his old favourite inight issue at last in some revival of aftection. But thus to limit the royal prerogative of merey, and set bounds to the range of royal sentiment and fancy, was very little to the taste of such a sovereign as Henry.

From amid the summer friends who had flocked around the cardinal in his arrogant splendour, but who now deserted him, there stood forth one firm and capable advocate, unchanged in his professions of attachment, to defend with equal zeal and good sense his neglected patron in his hour of adversity. This was the well-known Thomas Crumwell (so the name is spelt in the list of Parliamentary Burgesses, and in the State Papers), whose own interests, to some extent, were in jeopardy, together with his master's: for the secretary had borne a large share in some of Wolsey's most reprehensible sehemes and doings. But publie opinion, for the most part, was not eritical enough to detect this intimate connection; or was disposed rather to admire exemplary fidelity when so many menials failed their benefactor, than to fathom its secret motives with harsh serutiny.

It soon apppeared that the proeeedings against Wolsey in the House of Commons would misearry. In fact, it was not in accordance with the royal will to push severity to the extremest verge. Henry himself, having gained possession of his old favourite's ehattels and property, was eontent. 'The king did not wish the eardinal's ease to be tried by Parliament,' wrote Chapuys to the emperor, 'sinee, if it had been derided against him, the king could not have pardoned him.'

In that age a Parliamentary Session was commonly of no long duration; and on the present occasion, after six weeks of deliberative labour, weariness was suceeeding to ardour. Nembers, who had hastened with alacrity at a momentous juncture, at considerable cost and some risk, to contribute their assistance to the necessary work of domestic and especially ecelesiastical reform, soon found their stock of zeal quite spent. They had obtained but an inconsiderable earnest of the fultilment of their hopes; but this satisfied them for the time. They had enjoyed the gratitication of 
ventilating their grievanees, and reeiprocating their complaints; and they had become aequainted with authentic particulars of the much-detested eardinal's downfall. Absence from home had quickened their zest for their eustomary rural pursuits, and they were eager to keep Christmas in their own halls. Parliament, therefore, was prorogned 1)ecember 17 . It was hoped that the prorogation might have been earlier; but this was rendered impracticable by pressing stress of business. It is descriptive of the parliamentary condition of the age that on one day (1)eember 1\%) in particular, so close was the application to business. that 'the leading members had aetually no time to take any refreshment until very late at night.' This was noted as quite unusual.*

'The General Pardon of 'Thomas, Cardinal of York, Bishop of Winchester, and perpetual Commendatory of the exempt monastery of St. Albans; alies, late Bishop of Bath and Wrells; alias, Bishop of Durham; alias, late Chancellor of England, and Legate de latere of the Apostolic See: alius, sometime Bishop of Lineoln, and formerly ealled Thomas Wolsey, etc., the king's almoner,' is dated from York Place, February 10, 21 Henry VIII. (1530). A week later Wolsey resigned the see of Winchester and the abbey of St. Albans. (In February 12. he received a full parton; on the 1.th he was restored to the arehbishopric of York. All his possessions had passed to the king, and he had heavy debts to discharge. To defray these the sum of $\pm 6,37+3 \mathrm{~s}$. 721 d.--quite inadequate to the purpose-was awarded to him, $£: 3,000$ in money, and the rest in plate, horses, ete. A yearly pension of one thousand marks (abont $\$ 600$ ) was further assigned him. In consideration of these royal bounties he made a formal legal surrender to Henry of all that appertained to hin, the see of ' lork alone excepted.

Let it be mentioned to Wolsey's honour-after all due attention to the disparaging artieles of his impeachmentthat there shone in him with greater cleamess than ever, through the dismal environment of extreme misfortune, two admirable traits of eharacter. Very touching was his persistent devotedness to the well-being of his colleges, especially

$$
\text { * sp., ir., } 232 .
$$


the college which he had reared and endowed at Oxford. 'Prostrate at your majesty's fete, he wrote to Henry, 'with weping terys (tears), this shal be, in most reverente and humble maner, to recommende unto your excellente charyte and goodness the poor college of Oxford,'* etc.

A scarcely less noble trait was his steady personal attachment to his sovereign, notwithstanding treatment as ungenerous as it was unjust. Henry himself, however profuse of 'comfortable assurances,' was paltry and contemptible beyond expression in his niggardly transactions with his now rejected minister, whose talents had shed a lustre on his reign in the eyes of Europe. Wolsey, on the other hand, professed, with all the fervid glow of willing self-sacritice: 'The king has always been the real proprietor of all my estates and possessions; the use only has been mine. I had intended to leave all to the king, who has but prevented me.'

Sudden indeed-instructive in its moral lesson, moving in its deep pathos-was the ruin of this remarkable man, called to power at a turning epoch in England's progress, to shape by his genius the destinies of his country-perhaps the greatest name, all things considered, of all our statesmen - raised from humble obscurity to a dizzy eminence of authority by extraordinary endowments, which rendered him for some years the associate, almost on equal terms, of kings and emperor.

* The college was threatened by Henry's avarice and jealousy. 'My Lord Chancellor (More) fears that the king will in conclusion have your Grace's College, for all the supersedeas; but he added that Mr. Secretary (Gardiner) was active for its continuance,' etc.-Tresham to Wolsey, October 11, 1530. B. iv., part iii., biti?. 


\section{VII.-THE OBSCURE TO THE FRONT.}

SickNess of body, supervening on vexation of soul, saddened Wolsey's sojourn at Esher. Divested of his accustomed pomp, surrounded with few comforts, compelled for some time to borrow even 'dishes to eat his meat in, and plate to drink in, and also linen clothes to oceupy,' the discarded minister languished, and became alarmingly ill. 'I cannot live,' he murmured, 'in this moist or corrupt air.' When his fever was 'somewhat assuaged,' and the 'black humour' also, then his aecount of himself was, 'I am entering into the kalends of a more dangerous sickness, which is the dropsy'; so that, if I be not removed to drier air, and that shortly, there is little hope.' Leeches and 'vomitive electuary' were in requisition. His enemies suspected that he was endeavouring to work on the king's compassion, so as to attract a royal visit. ])r. Augustine, his Italian physician - before physician, it would seem, to Campeggio-who now filled the place previously occupied by Francis in the eardinal's houselold, thought it neeessary to call to his aid the best merlical advice. I)r. Butts was therefore despratched to Esher, and returned with the report that the ailment was ehiefly caused by sorrow of heart. The suffering cardinal was cheered by a present from the king himself, a ring with Henry's 'visage engraved within a ruby,' and from Mistress Amne, her 'tablet of gold,' taken hurriedly from her girdle, to please her royal lover. These gifts proved more salutary than the physician's medicines. 'Three other physieians were sent to assist Butts with their medieal skill. Their conjoint efforts and ministrations were successful. 'They set Wolsey 'on his feet, and got him a good stomach to his meat. 
In his humiliation W'olsey found 'sharper than a serpent's tooth ' the ingratitude of many, who had fawned upon him in his palmy prosperity. He appealed 'with rude and shaking hand' for help in his behalf by intercession with the king, to the sympathy of Gardiner, as his 'old bringer up and loving friend.' 'Having now but York, which is now decayed by $\mathfrak{f S 0 0}$ by the year, I cannot tell how to live, and keep the poor number of folks which I now have,' etc. In his 'great triumphant glory,' as he called his former basking in the Court sunshine, he had a household of 'four hundred and twenty-nine persons,' for whose use were slaughtered, in the October, just on the brink of his troubles, 'four hundred and thirty oxen' and 'nine hundred and nine muttons, * provision for the season following St. Andrew's tide, when meat was searce until the grass season came round. Now, how all was altered: But no entreaties, however pathetic, by whatever considerations enforced, could melt the stony heart of the self-interested Gardiner:

Happily all were not like Gardiner: The cardinal, in his 'agony,' had no more assiduous attendant than the sagacious secretary who had defended his master's reputation in the House of Commons. Thomas Crumwell, endowed with some good natural qualities, but by no means over-scrupulous, had demonstrated his usefulness, shrewdness, and boldness, while yet in the cardinal's service, in surveying and dissolving the monasteries doomed by Rome. Cavendish witnessed a memorable scene at Esher, in the 'great ehamber,' on 'Allhallowen day,' which he has reeorded. Crumwell appears 'leaning in the great window,' with a primer in his hand, 'saying of our Lady matins,' which 'had been since,' notes Cavendish, 'a very strange sight.' $\dagger$ His prayers are earnest. Tears distil from his eyes, fast as words from his lips. Cavendish inquires, 'What meaneth this dole?' He hears in

* Subsidy Roll, B iv., part iii., 5947, 6185. The tertii denurii from beef and mutton consumed hy his household in one year amounted to e.2ilt $17 \mathrm{~s}$.

+ He was not then a Protestant. Wordsworth reads: "Which had bine a strange sight in him afore.' For Crumwell had sometimes inclined to infidelity, rife in Italy at this periou.--Singer's 'Cavendish,' i., p. 194. See Maitlaud's 'Essays,' p. 230. 
reply, 'It is my unhappy arlventure, which am like to lose all that I have travailed for, etc. . . And thus much I will say to you that I intend, Cood willing, this afternoon, when my lord hath dined, to ride to London, and so to the Court, where I will either make or mar.'

That very night Crumwell rode forth, together with Sir Rafe Sadler, his clerk. The next day he was favoured by the king with an audience in his garden at Westminster, a spot already familiar to Crumwell. According to Foxe, Sir John Russell, to whom Crumwell had formerly rendered important service at Bologna, was the means of procuring for him this private interview with Henry. Russell had been a frequent channel of communication between the deposed statesman in his troubles and the Court.

It may perhaps savour of the marvellous to some minds, that Crumwell should have found so ready an introduction to the king. But it must be recollected that, besides familiarity with Sir .lohn Russell, his post of secretary and attorney to the cardinal had brought him into contact with many who were high in Court favour, and even with Anne Boleyn herself, a letter from whom, addressed to him before this period, is referred to in Brewer's Collection. $\dagger$

He was Wolsey's chief stay in the management of his donestic affairs as well as in smoothing the cardinal's trying relations to the House of Commons and to the Court at this period; as he subsequently proved the steadfast friend of Tom Winter, the cardinal's son, when Bonner and other summer satellites failed him. It has been the fashion to impute his singular constancy - that he alone was 'faithful found among" the faithless - - to a spirit of far-seeing self-interest alone. Such an explanation does not meet all the facts of his behaviour, or of his character. However mprincipled he may have been, he was certainly not devoid of native sparks of generosity and kindliness.

The cardinal was at a loss for the pecuniary means to discharge the salaries of his household. Crumwell suggested

* 'Ralph sadleyer' was son to 'Henry sadleyer' in the service of the Marquis of Dorset, in whose family Crumwell had been in early life. -... B. vist.

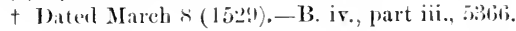


that his servants should be summoned, one and all, into 'my lord's presence.' Knowing the emptiness of his purse, Wolsey demurred, observing, 'Nothing hath no savour.' But the secretary persisted in his request; and when all were in attendance, turning to the cardinal, he said, 'Sir, there are divers of your yeomen who would be glad to see their friends, but they lack money; and here are divers of your chaplains who have received great benefit from you, let them now show their humanity.' Crumwell himself set the example, and bestowed the handsome contribution of tive pounds. The chaplains followed with such liberal sums as were sufticient to enable Wolsey to discharge all his debts to his household.

With similar dexterity Crumwell suggested to Wolsey to grant pensions out of the see of Winchester, and the lands of St. Albans, to various persons who were high in influence at court. With this adroit proposal the cardinal complied. George Boleyn, Anne's brother, Henry Norris, Lord sands, comptroller of the household, and Sir John Russell-the last afterwards, like Crumwell himself, one of the 'leviathans '- to use Edmund Burke's metaphor, battened on the convent spoils -were among the grantees. By a stretch of legal acumen, in keeping with that interference with the purity of justice, which, together with the rack and the spy system, had been introduced, or notably encouraged, by Edward IV., these grants were pronounced valid. Crumwell's manceuvre in this instance answered a dunble purpose. Not only was enmity appeased, which still rankled in many breasts against Wolsey, but court patronage of no insignificant weight was at the same time conciliated in support of Crumwell himself.

It might have been anticipated that there would be some stubborn obstacle against Crumwell's creeping into the royal contidence in the strong prejudice which his numerous extortions in dissolving the lesser monasteries, and the many questionable contrivances which he had resorted to for endowing the two cardinal colleges, must have engendered in Henry's mind. It was not, however, an age of severe ofticial probity. Wolsey's downfall had placed Henry in a new and difficult position, and transferred onerous work to hisown hands. A minister, therefore, of large business experience and calpacity, 
unfettered by scruples, of proved fidelity to his employer, possessed substantial recommendations to the employ of a inonarch who found himself divested of the powerful support of tried capacity previously ever ready at his side. Guaranteed efficiency countervailed a host of blemishes, which might be reckoned rather to the master's account, and in the servant might be construed as signs of too zealous haste to do acceptable service. Not that Henry was blind to Crumwell's unscrupulous morality. A well-known anecdote, of a somewhat later date, attests that when in playing cards a knave was dealt to him, the king would exclaim, 'I have got Crumwell!' But such conviction did not prevent his making use of Crumwell for his own ends. Henry was a keen-sighted judge of men, whatever may be thought of his judgment of women. And doubtless he discerned in Crumwell at the first interview the exact tool he required to fill an ardnous post. His fidelity was in an especial degree a precious jewel in royal estimation. None of those who trampled upon Wolsey in his distress ever afterwards received courtenance at court. No one had a more true and quick sense of what was right and becoming than Henry, when the clearness of his moral vision was not obstructed liy passion or by self-interest.

A Romanist writer, who is careful so to paint ('rumwell, as not only to omit no foul shade from the colouring which has any existence, but even to insert some darker and blacker of his own imagining than all other shades, has rentured to arvance the statement that on the occasion of the first interview he placed in his sovereign's hand the actual license, under the king's broad scal, for exercising the oftice of legate, on which Wolsey relied for his entire vindication. Such a presentation wonld have furnished an easy and interesting introduction to rosal notice, no doubt. But it does not reflect the credit due on some other accounts to the writer referred to that he omits altogether from consideration on this subject the plain words of Cavendish himself. That such an act of

* Gasquet's 'Monasteries,' i., p. 392. His authority is Arundel MS., 152, f. 406. P.M. "Like an unfaithful and traitorous servant, the said Crumwell stole from his master and delivered to the king,'etc. The reference should be Arundel MS., 15\%, f. to b. (back), as Mr. Vicars of the B.MI. saw at once.- See Singer's '('avendisb,' i., pp. '20!), etc. 
treachery never entered the notions of Wolsey's gentleman usher, in writing his master's biography, is matter of certainty. He represents the cardinal as saying: 'I have the king's license in my coffers, under his hand and broad seal, for exercising and using the authority thereof in the largest wise, in his highness' dominions, which remaineth now in the hands of my enemies.' It is inconceivable that by 'the hands of mine enemies' Wolsey meant the king's hands. He intended, of course, the hands of Norfolk and Suffolk. The words imply palpably that on Wolsey's indictment as guilty of high treason his papers and documents were seized by his enemies. Remiss indeed would the two dukes have been had they failed to avail themselves of such an obvious precaution. The encomiums of Cavendish, and others as reported by him, on Crumwell - how he was 'esteemed the most faithfullest servant to his master,' etc., are quite incompatible with the belief or thought that the secretary can have filched such a document as the royal license from his master's papers. It is only on the clearest evidence that the memory, even, of Crumwell deserves to have the turpitude of treachery made to swell the sum of his iniquities.

In the first interview, no doubt, Crumwell struck the keynote of Henry's future policy. The conversation fell, of course, on the Bill of Attainder against Wolsey. That Bill, it was readily agreed, should be quietly set aside. That Henry should constitute himself head of the Church, and thus make the only power in the realm capable of withstanding his absolutism the footstool of his feet, and then should use his own courts of law for the settlement of his great matrimonial cause, was also, without question, a principal topic of conversation; for a statement to that effect was subsequently made by Crumwell himself to Cardinal Pole. And there is little room for question that the notorious scheme of bleeding the whole body of the clergy freely, by condemning them in a promunire, was either now distinctly broached, or, at least, shortly afterwards was considered and arranged in an early discussion. Crumwell well knew what superlative attractions such a scheme must possess for a 
sovereign such as Henry, embarrassed in his pecuniary circumstances by his extravagance, and resisted by the majority of the elergy, openly or secretly, in a point so near his heart as his contemplated divorce. Such scruples of conseience as he may have had Crumwell could easily reconcile to a plan that promised vengeance for his patron on those who hated him: who, moreover, were little less eulpable than himself; if, at least, a shadow of real blame could be supposed to attach to either. For the actual law-breaker was the king himself. But the occasion was opportune, and not to be permitted to slip by. The clergy were far from standing high in popular esteem. And it would be well to render them more docile in contemplation of radical changes, already in the royal mind in embryo, and soon to shape themselves into actual fact. It was true that the whole nation was technically little less guilty than the clergy, for the legatine authority had been accepted everywhere. But by a distinetion, bearing "on its face the stamp of Crumwell's unclerical bias and wily policy, it was given out that the laity had no ground for alarm, but might safely rely on the royal clemency.

The result corresponded to Crumwell's calculations. The laity saw the clergy mulcted without raising even the faintest murmur of disapproval; on the contrary they hoped to be thereby spared themselves. The arrangement soon afterwards effected between the Church and the king was of the nature of a highly convenient bargain. The Convocation of Canterbury submitted to grant one hundred thousand pounds;* but conjoined to the grant the express stipulation that Henry should co-operate with them in opposing Lutheran doetrine. The Church, on her part, thus became authorized to look to Henry as her pledged protector; Henry, on his part, at a time

* 'The Convocation began at St. Paul's, Nov. 5, 1529.

' ( irant of $£ 100,000$ for a general pardon . . . to be paid in five yearly instalments.'

Chapter House, Westminster, March 4, 1530.

Certified to the King, March $: 2.2$.

The August following the clergy rioted and assaulted Stokesley's Palace at St. Paul's.

Convocation granted, January 24, 15:31, a subsidy of $£ 100,0448$ s. 8d.B. iv., part iii., 6047 ; B. v.. 92.8. 22 Henry VIII., c. 15.

The Convocation of York, granted $£ 18,84010$ s.-23 Henry VIII., c. 19. 
when the coffers left full by his father were completely drained,* and when to obtain a subsidy involved irksome negotiations, and sometimes required force to boot, had his exchequer replenished at the sole cost of the intimidated spirituality. Nor was Henry at all loath to be the avowed and pledged champion of so-called Catholic doctrine. He was 'more severe' against heresy 'than the bishops themselves;' so at least More wrote to Erasmus. $\dagger$

Thomas Crumwell was one of the two burgesses who represented Taunton. $\ddagger$ There is now no doubt that the celebrated Petition of the Commons, imploring reformation of ecclesiastical wrongs and abuses, already spoken of, is chiefly to be attributed to his good sense and vigorous hand. For the earlier drafts in the Record Office are allowed to be in his handwriting; the document is in strict agreement with his opinions and tendencies.

What is less easily to be reconciled with his keen sense of self-interest, is that he should have stepped forward to reply to the articles of Wolsey's impeachment, and thus advocated the cause of a fallen man. Something has been said on this subject already. It may be repeated that, although at the first blush it may seem strange that one struggling for place and power should swim apparently against the tide, and sustain a cause, the advocacy of which seemed to offer little hope of leading to selt-advancement-yet that the real nature of the case was not quite correctly, or at least completely, divulged by the facts on the surface. The cardinal's cause was to some extent Crumwell's own cause. His faithful championship of the character and doings of a persecuted benefactor elicited warm admiration. But besides these considerations, his advocacy moved safely in the full current of the royal inclinations. For Henry was quite content when he became possessed of his minister's wealth. As to the charges alleged, he knew them

* Henry was released from his debts by Statute, in consideration of the employment of his own funds as well as the taxes in the defence of the Church and kingdom, and in establishing a universal peace.-21 Henry VIII., c. 24.

+ B. vi., 303.

+ B. iv., part iii., 6043 . 
to be simply absurd, or, at least, to have little intrinsie worth ; and desired that the impeachment should prove abortive.

Crumwell has been compared by Lord Campbell to a slave, metamorphosed into 'grand vizier in an Eastern despotism.' The after-stages in his upward progress were as speedy as the begimning had been sudden: a Privy Councillor, 1531, soon after Wolsey's decease; Master of the Jewels, April, 15:32; in July of the same year, Clerk of the 'Hanaper (Exchequer) of Chancery;' Chief Secretary to the King, in place of Gardiner, in April, 1534; and the same year Vicar-General, and in October, Master of the Rolls. The year 1536 opened with Katharine's death, and was stained by the decapitation of Anne (May 19); the close of July was rendered gloomy by the untimely decease of Harry Fitzroy. But it was a fortunate year for Crumwell. In that year he was made Lord Privy Seal, and a peer of the realm; he was also raised to the post of Lord Vicegerent in ecclesiastical causes. In 1537 he added the deanery of Wells to 'divers benefices.' In 1539 he was Great Chamberlain. One year more of fortune's treacherous blandishments, and ruin, yet more rapid than his rise, elosed his memorable life.

He shines more brightly in his master's 'agony,' by strong contrast with Gardiner. Both were indebted to Wolsey for their bringing-up and first promotion. But when the catastrophe came, and their patron's disgrace tested the characters of those associated with him, it was suspected by shrewd observers that Gardiner used his proximity to the king's person-not to lessen, but to aggravate the cardinal's misfortunes-so that he might himself reap a rich harvest from his overthrow. To the cardinal's complaints of hard usage from the Court-so that he was left without enough to 'live withal' - the king's secretary replied that the fault was Wolsey's own, for he might 'have taken sufficient,' but would not do so, in order that 'the show might be the greater when it should be presented to the king's sight; nor did ye not confess all your debts, but concealed very much, so that the king hath paid four times double more than was thonght he should.' Du liellay arrived at the conviction that Gardiner and Tuke were alike traitors to the cardinal; and in expressing his 
abhorrence of their treachery he added, "the worst is, the cardinal does not perceive it."

On the other hand, Crumwell declared, and his sincerity was evidenced by his conduct-' I am, and during my life shall be with your grace, in heart, spirit, prayer and service, to the uttermost of my power.' The cardinal threw himself upon Crumwell's pity and help, as his one earthly prop, calling him ' My only ayder in this myn intollerable anxiete ;'-' my only refuge and aid ;'- ' mine own good Thomas.' And what doubts might crop up at times as to the perfect fidelity of his advocate and friend, from misgivings arising from the secretary's notorious self-seeking propensities, were dispelled by renewed protestations of thorough devotion.

No one knew better than Wolsey that the real strength of the opposition which had overwhelmed him, its centre and force, lay with Anne, whose influence over Henry at this time was paramount. He therefore fervently entreated Crumwell to 'practise that the Lady Anne may mediate for him.' 'All possible means must be used,' he urged, 'for atteynying of her favour.' Crumwell was willing to do what he could. But, with outspoken honesty, Anne never attempted to conceal her aversion, and refused to give any promise of assistance.

Some passages from Henry's despotic reign read like chapters culled from Oriental romance; none more so than the adventurous career and rise of Wolsey's remarkable successor, who, as adviser and minister, wielded for some time, under the force of circumstances, a power greater in some respects than that of his fallen master.

Crumwell was born at Putney, and was, according to Foxe, the son of a blacksmith, or of a fuller. His father, it seems, had managed an iron-foundry; and after his decease the widow married a cloth-merchant. He was stigmatized as a

* B. iv., part iii., 5945, 6112, 6548. Ralph Sadleyr wrote to Crumwell : 'London, Thursday, 8 p.m. (December 29, 1529).

'I think he (Gardiner) will do little or nothing to my lord's avail, or to that of any of his friends, more than he may not choose for very shame, considering the advancements,' etc.

Crumwell stated that his efforts in Wolsey's behalf cost him $£ 1,000$. But his indirect gains, as Wolsey's secretary, must have been very considerable. -See B. iv., part ii., 4613 ; part iii., 6754 ; B. v., 311. 
low-born knave by jealous nobles; but, according to Froude, he traced his lineage from the Lincolnshire Crumwells. He seems to have been early in life in the service of Cecily, Marchioness of Dorset. But a roving propensity soon led the orphan lad-now a neglected scapegrace-abroad. His account of himself to Cranmer was, that he had been a 'ruffian.' Foxe narrates that he served as a trooper under Bourbon, and that he was present at the sack of Rome. But to his military life a much earlier date must be assigned; and if he was present at Rome in 1527, it is more likely, as Maitland has observed, that he was there on some special errand from Wolsey. Foxe was a laborious, and yet a careless editor; rather an ingenious, than at all times an ingenuous compiler.* Fact and fiction, or at least statements that rest on slender basis of fact, blend in his lively narratives. Much that he narrates of Crumwell was, without doubt, derived from Cranmer, and must thus be regarded as strictly trustworthy.

Italy, then the most civilized country of Europe, was the scene of the adventures and vicissitudes of Crumwell's youth. And, ungainly as was his person, his manners eaught some polish and refinement from Italian literature + and society. It is related that Frescobaldi, whose banking establishment was as celebrated at Florence as that of the Fuggers at Augsburg, and who had monetary connections with Wolsey, and other Englishmen of note, took a fancy to the quick-witted youth, and gave him pecuniary help.

Foxe states that Crumwell committed to memory the Latin text of the New Testament, recently published by Erasmus. On this statement I ean Hook has remarked, with that hasty caprice which sometimes stains his writings, that 'it is more than doubtful whether Crumwell ever understood Latin

* Foxe published at Strasburg, 1554, in Latin, the first book of his 'History of the Church and its Chief Persecutions,' etc. A second Latin edition, much enlarged, was issued at Basle, 1559. His first English edition appeared 15t33; a second English edition, 1610. He died 1587. The most complete edition, 'Acts and Monuments,' three vols., folio, was not published until 1684 .

$\dagger$ Crumwell lent Italian books to Edmund Bonner, Wolsey's chaplain. -B. iv., jart iii., 6346. Italian was taught in that age in some of the best schools. 
at all.' Strange then, it must be confessed, that some of Crumwell's agents habitually wrote to him in Latin; and that Latimer, a personal friend, on one occasion addressed to him a letter, wherein he alluded to the great minister's character, certainly in highly complimentary terms, the more complimentary part of the letter in Latin.* Strange, too, that a man of no slight intelligence, and well versed in Italian, should have often heard the Church services, and on one memorable occasion 'said of our Lady Matins,' without having, or caring to have, any knowledge of the language employed. The statement of Foxe in question probably rests on some basis of truth. Crumwell was not a thoroughly good Latin scholar no doubt; he did not know Latin as he knew Italian; but he cannot have been quite ignorant of what was then the great tongue in matters of ecclesiastical business, as well as of devotion and controversy. Just as Macaulay, to acquire for historical purposes a serviceable knowledgre of some modern language, would read the New Testament in that language, so Crumwell may have studied-and probably did study-the clear and easy text of the great Dutch scholar's Latin version of the New Testament + - a book popular both in Italy and in England. Latin was then more than French the universal language, f not only with men, but with educated women also ; and a tolerable knowledge of such a general medium of communication throughout Europe would be very useful, not to say necessary, for getting on in the world.

Italy was at that epoch in advance of England, and of the rest of Europe, in mental culture. The greatest poet since

* 'Thus much now I will say, ande natt say it alone, but with many, that your lordshype won man have promotyd many moo honeste men, synste God promotyd you, then hath many men doon before your tyme thowgh in licke authorite with you.

'Tanquam non tibi natus soli, sed multorum commodo: efficiat qui omnia facit, utiu eundem finem diutissime vivat dominatio tua, ut sic inter nobiles nobilissimus evadas,' ete.-H. L. Wigorn., Hartlebury, December 13 (1538?). 'Suppression of Monasteries,' C.S., p. 149.

$+\mathrm{A}$ letter of Coverdale, without date, but prior to 1527 , speaks of Crumwell's 'fervent zeal to virtue and godly study.'-B. v., 2.21.

$\mp$ At Westminster, April 7, 1533,8 a.m., were assembled in council the Chancellor, the Earls of Wiltshire and Essex, Crumwell, ete. Chapuys asked whether his discourse should be in French or Latin. 'In Latıl,' was the reply, for ' they did not all understand French.'-B. vi., 465. See B. จ., $30.2,574,1188$; vi., $23 t$. 
Homer had been a Florentine; although he composed his Divine Comedy an exile from the city of his birth and his affections. The sweet Tuscan had succeeded 'the beautiful language of Oc,' as the vehiele of poetry, imagination, and love. Refinement, driven from the banks of the Garonne by the rude warriors of Northern France-the ruthless executors on the Albigenses, as tainted with the heresy of the Manichees, of the vengeance of the papacy-had found refuge on the banks of the Po and the Arno. There opulent cities, enriehed with varied works of art, shone with a magnificence unrivalled elsewhere. But the Italian nobles and merchants, whilst bidding exorbitant sums for newly-found manuscripts of the classics, and proud to display in their galleries masterpieces of painting and sculpture, had lost the vigour needed for the defence of their accumulated treasures. For this purpose they were constrained to have recourse to the swords of mercenaries, if at least the tricks of diplomacy were insuffieient. Thus it had come to pass, that in Italy the point of honour was not courage or truth, as in other countries, but rather ingenuity. Machiavelli's notorious treatise, The Prince (Il Principe), published in 1532 under the sanction of Clement himself, only reduced to writing a system of selfish policy, and unscrupulous practice, of which the papal government was the most finished speeimen, although its prevalence was general in the country of the author. Of the spirit of unprincipled and treacherous statecraft, of which this book was at once the transcript and the manual, Crumwell had drunk deeply.* In Italy the Renuscence was marked by free-thinking tendencies on the subject of religion; and these also told on Crumwell.

After a time Crumwell worked his way into the professional groove best suited to his talents. As eommercial agent to one of the Venetian traders, and then clerk to a firm of merchants at Antwerp, his business capacity gained recognition. The story ran, that he was thus chosen to procure for the town of Boston, in Lincolnshire, certain privileges from the pope. Foxe

* Crumwell recommended to Cardinal Pole the writings of Machia velli,

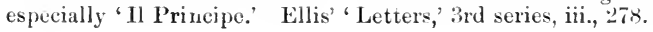


is pleased to recount an extraordinary tale of his gratifying the ' holy tooth' of Julius II. with some delicious jelly, which he caused to be brought in 'with a three man's song,' and presented to his holiness, when he was 'new come from his hunting;' whereby his petition was at once granted. But these Boston Perclons were in reality, there can be little doubt, merely a ribald jest on popular credulity-a hoax in mockery of the monks and their wares; and the tale of the attractive jelly looks like an amusing fiction in ridicule of the habits and tastes of the unsaintly Julius.

By marrying the daughter of a wealthy wool merchant, Crumwell raised his social position. In 1512 he was a thriving factor, or general merchant, at Middelburg, in Zealand. Nor when he became secretary to Wolsey, and afterwards to the king, were his lucrative commercial transactions relinquished. On the contrary, according to the custom of the times, he used to the full the opportunities thus more amply furnished for pushing his gains. About 1520 he became a scrivenerlawyer and money-lender conjoined-and bettered his fortunes by advancing money on loan, at handsome interest, to younger members of the aristocracy. There remains to us the account of the purchase in the Low Countries of an iron safe for the secure custody of his cash.* In 1523 he contrived to get returned to Parliament. In the same year he was drawn into relationship_probably into closer relationship-with Wolsey, to whom his first introduction may have been through his advancing money to Henry Percy, one of the cardinal's household. The commission to Crumwell, conjointly with others, to survey certain monasteries 'about to be converted to the uses of Cardinal's College,' bears date January 4, 1524. 'Thos. Crumwell and John Smith' were afterwards appointed Wolsey's attorneys for his college. The effective services of the cardinal's attorney in breaking up some of the lesser monasteries educated him for a similar task on a much larger scale, under the king himself, to whose confidence he was recommended by a rare combination of qualities-some good, some badespecially by shrewdness and energy, experience in business, * Bought by Vaughan for $£ 8$ Fl.-B. iv., part ii., 4613 ; part iii., 
devoted fidelity, and freedom from the smallest approach to impracticable scrupulosity. His views of government were even yet in autocratic advance of Wolsey's, and he completed Henry's absolutism. Wolsey put Henry's feet on the neck of the laity; Crumwell subjugated the elergy also to the authority of the Crown.

A little earlier, one who was to be associated with Crumwell in designing and achieving radical ecclesiastical changes, had been introduced to the king. It may be remarked, in passing, that the illustrious Cranmer, like a large number of the more influential spirits of that age-such as Crumwell himself, Wolsey, More, Norfolk, and little Bilney-bore the Christian name of 'Thomas.'* Cranmer's rapid advancement was only so far less extraordinary than Crumwell's, that in medieval times the Church was the recognised ladder to rank and power, and that his personal character was devoid of the least stigma of reproach.

In the first week of August, 1529, Henry had intended to visit 'the More,' in Hertfordshire, described as 'a commodious residence in the summer,' belonging to St. Albans Abbey. $\dagger$ Hearing, however, that the sweut-the very name whereof was 'fearful and terrible to his Highness' ears '- had been 'thereabouts,' he changed his plans, and risited Tittenhanger-a house also appertaining to Wolsey, as Abbot of St. Albans. Gardiner, the king's seeretary, and Edward Fox, his almoner, were in attendance, and were lodged by the harbingers at Waltham Abbey with a Mr. Cressy. The supper hour came, and the courtiers were surprised to meet at table an old Cambridge aequaintanee, Dr. Cranmer, of Jesus College, who had been driven by the plague from Cambridge, together with his pupils, Cressy's two sons. Cranmer was of good birth, son of ' Thomas Cranmer, of Aslocton, Esquier,' in Nottingham-

* Stapleton's 'Tres 'Thomæ' comprise the Apostle, the Canterbury Saint, and Sir Thomas More. Had Dr. Stapleton written the lives of the 'Thomases of llenry's reign, his biographies would have covered the chief events of the period.

† Incorrectly stated to belong to the see of York in 'Paston Letters' (Fenn's), i., p. 2\%4. 'The manors of More and Tytenhangre 'were assured to Henry, Jamuary, 1531.- B. v., 78. 'The More' was granted to Henry 'by Robert the Abbot, and the convent of St. Albans monastery, November 1, 1531.-B. v., 600. 
shire, and was held in repute for learning. The conversation, as was natural, fell upon the royal divorce question, and Cranmer was requested to pronounce his opinion as to the right mode of procedure. Shy and thoughtful, at length he observed, 'I am not beaten in this matter as you have been; howbeit I do think that you go not the next way to work, as to bring the matter unto a perfect conclusion and end, specially for the satisfaction of the troubled conscience of the king's Highness.' He then offered his suggestion that eminent divines should be consulted on 'the one truth in the matter,' whose 'sentence may be soon known', he said, 'with little industry and charges; and then his Highness, in conscience quieted, may determine with himself that which shall seem good before God; and let these tumultuary processes give place unto a certain truth.'* Cranmer thus swept aside altogether the decision of the pontiff, and referred the question to the judgment of the soundest and best informed theologians, whose verdicts were to be carefully compared and weighed. The king himself was to be the ultimate juclge, and, of course, was to give legal expression to his deliberate conclusion, through the constitntional channel of the national courts. Such advice showed that Cranmer had already ceased to be a papist. But of many minds at that juncture, clerical as well as lay, he was, in speaking as he did, the faithful mouthpiece.

Two days later, Gardiner and Fox communicated to the king at Greenwich the conversation which had passed over the supper-table at Waltham. 'Where is this Dr. Cranmer,' inquired Henry, adding, with his customary oath, 'I trow he hath the right sow by the ear.' Cranmer was sent for 'out of hand.' In his interview with Henry his words were received with satisfaction, and he was retained to 'pen the matter at large.' He was lodged with Anne's father at Durham Place, the books needful for thoroughly sifting the question being supplied to him. He was made Anne's tutor.

It has been surmised that Cranmer had been previously known to Lord Rochford. In the despatches from liome early

* Morice's 'Anecdotes,' Narratives of the Reformation, C.S., pp. 218. 233 , and $241,242 .-B$. vi., preface, 1'. ix. 
in 1528, mention is made of 'Lord Rochford's priest.' This mysterious person arrives early in the January of that year with letters from Wolsey to the English ambassadors, and after a stay of about three months returns with despatches.* Brewer identifies 'lord Rochford's priest' with Cranmer. There can be no doubt that some difficulties on the face of Morice's narrative would thus be removed. That Cranmer should be Anne's tutor, when she was twenty-two years of age, is accounted for if he had begun to hold the office at an earlier date. And inasmuch as the suggestion which he offered at the supper-table contained nothing either very novel or very striking, his being sent for by the king with urgeney is more easily explained, if a friend at the royal elbow, in the person of Anne herself, prompted the summons.

It appears, however, that the identifieation must be abandoned, notwithstanding Brewer's high authority. Under the designation of 'Lord Rochford's priest,' it is far more probable that John Barlow was intended. It even seems to settle the question that Kinight wrote January 10, 152s, 'the dispensation is sped, and under lead, according to the minute brouglet by Barlow.' $\dagger$ Afterwards Lord Rochford requested of Wolsey for Barlow the benefice of 'Sonderych (Sondridge), vacant by the elevation of John Allen-or Aleyn-Crumwell's coadjutor in the dissolution of the lesser monasteries, to the Archbishopric of Dublin. And there is extant a letter from Anne herself to the cardinal, thanking him for the gift of the benefice to Barlow. Cranmer, however, may have been previously known to the Boleyns. A despatch of the Venetian ambassador at the French eourt, states that he was a kinsman (parente) of Anne, as well as a very intimate friend. + But that he was not Lord Rochford's priest, according to Brewer's conjecture, appears to be well nigh certain.

Crammer's treatise, long supposed lost, has at length been found in the British Museum. It proved of service to the king's

* Sir Robert Jerningham to Wolsey, January 10, 1528 : 'M y Lord of Rochford's priest arrived on Monday.' Gardiner to Wolsey, April 1:3, 15:8 (Easter Monday) : 'Since the despatch of my Lord of Ruchford's priest,' ete.-13. v., 3784-90, 4167 . See B. iv., intro., p. cecxliv.

$\dagger$ B. iv., part ii., 3784,3767 .

+ Ven., iv., 871 . 
cause in Gardiner's hands. And thus Cranmer had risen high in court favour already, when he passed to the continent (January, 1530) in company with Anne's father, now Earl of Wiltshire and Ormond, together with Lee and Stokesley. They were commissioned to deliver Henry's salutations to the emperor on his coronation, and besides other matters of negotiation, to use their best endeavours to prevail with Charles to forego his opposition to the divorce. As regards this principal object, the embassy was so complete a failure that in Henry's judgment it threw discredit on Wiltshire. A contemporary document records: "The king is also encouraged by a wonderfully virtuous and wise man, who says that he is not to be considered pious, but impious, who transgresses his master's law for the sake of a servant, and fears more to offend man than God.' It is thus that Cranmer was probably described-severe as is the condemnation which the words contain on several passages in his own subsequent career.

Bologna, to which Wiltshire passed, was to be the scene of the coronation. The emperor had reached this city the preceding November, and Clement a little before him. For the meeting of the potentates a stage had been erected, where Clement took his seat on a throne, adorned with a superb mantle, his jewelled mitre on his head. With great reverence Charles approached his holiness, clad in complete armour, except that for a helmet he wore a black cap, which he doffed as he drew near to the throne. Submissively kneeling-contrary to Burnet's account-he kissed first the foot, then the hands, and lastly the pontiff's face. The gaieties of Bologna, and the festivities of the imperial coronation and winter sojourn, were not witnessed by Cranmer, who pressed on, according to his instructions, to Rome itself. In the papal city he was well received, and was appointed Penitentiary of England, thus obtaining, ex officio, ready access to the pontifical library,* at a time when the fathers of the Church and the records of councils were busily canvassed on the matrimonial controversy. What he beheld day after day

* To this Croke was unable to gain entrance.-B. iv., part iii., 6105, 6354 . 
in the metropolis of Christendom inspired the prayer, which he afterwards declared he daily offered, that he might 'see the power of Rome destroyed.'

In the summer of 15.31 Cranmer-as his 'Remains,' published by the Parker Society, show - was again in England; and not long afterwards was sent ambassador into Germany. Here he was favoured with an interview by John Frederic, the Magnanimous, of Saxony, as well as by his secretary, Luther's firm friend, Spalatin. But the alliance, which was the object of these interviews, failed of accomplishment. The German princes had been caressed by Charles, and had secured advantages by the Peace of Nuremberg, for the loss of which a prospective league with England would have been scant compensation. At Ratisbon Cranmer saw Granvelle; and at Lintz he had an audience of Charles himself, and wrote to Henry that after the brief Turkish campaign the emperor was hastening into Spain, and, in crossing through Italy, would speak with the pope and treat of a General Couneil. And 'I do think,' he added, 'that he will not forget to make mention unto the pope of your grace's great cause.' Cranmer must have been cajoled by the emperor.

It was during this embassy that Cranmer married his seeond wife." His first wife, Joan-married before his ordination (1523)-had deceased, together with her babe, within a year of their union. The seeond wedlock now contracted was a bold step, and was, therefore, kept secret. For, though a priest might hold a concubine on payment for the license, he was not free to contract the tie of holy matrimony. Cranmer's seconri choice was the fair Margaret, niece of Andrew Hoseman (Osiander), pastor of Nuremberg, an eccentric divine, $†$ a student of the Scriptures, not in full accord with Rome, yet searcely a Protestant.

Cranmer was preparing to follow the emperor from Vienna

* Margaret bore Cranmer a son, Thomas, and two daughters-Anne, who died before him, and Margaret. His widow was married again twice.

'Black Joan,' his first wife, was of kin to the landlady of the Dolphin, whence the scanclal that the husband had been ostler, and the wife tapster, of that inn. On.Joan's death Cranmer was re-elected a fellow of Jesus.

+ On Osiander's opinions, see Newman's 'Lectures on Justification,' appendix, pl. $43, i, 437$. 
to Italy, and thence to Spain-through a country devastated by war, the imperial troops being worse oppressors than the Turks, the peasantry retaliating in robbery and murderwhen a missive, and again a more peremptory missive, from Henry interrupted his plans, and recalled him home. The learning, piety, genial humour, and bounty, which for nineand-twenty years had adorned Lambeth and Croydon, had passed (August 22, 1532) to a better world. Henry's resolve was unchangeably fixed-to Gardiner's intense chagrin-to have no other than Cranmer as Warham's successor.

By a letter to the emperor, dated November 1, Cranmer was recalled. On the 19th the future archbishop commenced his return journey. He was in no hurry to reach home, for he anticipated, not without some dismal forebodings, the too probable difficulties and troubles of his new and exalted post. Every morning, after October 5 and 6 , he noticed in the east, with unfeigned alarm, 'a blazing star, called comete.' 'God knoweth,' he wrote to Henry, 'they do not lightly appear, but against some gieat mutation." Crumwell's confidential agent, Vaughan, was directed to conduct the archbishop-designate to England. A letter of Vaughan, dated December 9, conveyed the intelligence: 'At Lyons I met an Englishman who had come from Mr. Cranmer'-who was then only ten leagues distant. 'The news,' Vaughan continued, 'will please the king. Early in the morning I shall ride towards Mr. Cranmer, whom I will conduct in safety, or die by the way. . . . I trust by Christmas we shall be in England, although Mr. Cranmer is disposed only to make short journeys.'

It appears, by the correspondence, that 'Thomas Elect of Canterbury' was sojourning February 8, 1533, in 'Chanon Rowe, in Westminster.' His elevation, which seemed more than abrupt in its suddenness, everywhere occasioned surprise and conjecture. The surprise was increased by the unusual promptitude of the royal proceedings. "One of the causes of the general surprise,' wrote Chapuys to Charles, 'is that the king usually leaves benefices vacant for a year, for the sake of the revenues, which then belong to him; and this bishopric has not yet been vacant four months. Besides, the king has * The comet was followed by other grave portents.-Ven., iv., 773. 
advaneed the money for the expedition of the Bulls, so as to have no delay. It is suspected that the object of this haste is that the arehbishop, as legate of the kingdom, may authorize the new marriage in this Parliament,' ete. The necessary Bulls were reeeived only five days before Cranmer was consecrated Primate of all England. The conseeration took place on Monday, March 31, 1533, Convocation being at the time in session.

He has himself stated that he grieved to leave his study, and felt his inability for the post, and especially disapproved of the means whereby he 'must have it.' The oath to the pope contradicted the oath to the king. It was ' elean against his eonseience' to swear to defend 'the regality of St. Peter, with the rights, honours, and privileges of the Chureh of Rome;' and to swear also that he held the see 'of the ling, and of the king only.' But a simple expedient quieted his qualms of conscience. He protested that he did not bind hinself by his oath to the pope to do anything against the king's prerogative, or to refrain from taking measures to reform the Chureh of England. Chapuys transmitted to Charles the eurrent rumour that the new archbishop was a Lutheran. To this surmise the protest lent strength. Its terms were no indistinct sign that the king's decision was resolutely fixed to reform those vices, abuses, and seandals of the Chureh which he was ever denouneing in familiar conversation. Cranmer was empowered to act as papal legate, and 'pardon was granted to the said Thomas, late Arehdeacon of Taunton, of all trespasses and offenees against the Statutes of Provisors and Premunire."*

Crumwell and Cranmer were in all probability already known to one another. They were both similar in early obseurity, however dissimilar in essential points of eharacter. Crumwell by quick degrees suceeded his master, Wolsey, in temporal government, but with ideas and principles in ecelesiastical matters very much more in conformity with those of Crammer. As early as November, 153:3, Chapuys communieated the intelligence to the emperor: "Crumwell has shown himself welldisposed to your suljects, which is important, for he rules * B. vi., 291, 578 (7). 
everything.' Cranmer before very long filled a sphere never occupied by Warham. They were well fitted to work conjointly, and to put into execution the royal plans for the reform and establishment of the Church on a national basis.

Cranmer, although not professionally a lawyer, had, like Crumwell, a legal mind-clear, sound, practical; which Henry, a great stickler for the forms of law, appreciated highly. Crumwell possessed the cleverness and adroitness of the successful adventurer. The most mercenary of men in a mercenary age, his good natural qualities must not on this account be denied. He was affable, easy of access, hospitable, good-natured, and far from ungenerous. Sir Thomas Elyot spoke of Crumwell's 'old gentle nature.' But the chief object proposed to his ambition was to aggrandise his family, and amass a fortune for his son Gregory - who no more resembled his father in intellect than John Nore resembled the gifted Sir Thomas. For his low expediency principles and disreputable practices some extenuation may be found in his early random training, his Italian habituations, and the grovelling condition at this period of English society itself. For his enlightened conception of the true relations of Church and State all England owes him a large debt of lasting gratitude.

Cranmer's intentions were pure and upright; he was merciful, amiable, and forgiving. $\dagger$ He was even bold physically, and 'feared not,' according to Morice, 'to ride the roughest horse that came into his stable.' His deficiency in moral courage-attributed to harsh treatment in boyhood from a cruel schoolmaster-has been a foul blot upon a memory endeared by personal piety, as well as by public merits. $\mathrm{He}$ was never the sturdy oak to bear erect the storm's fury, but the pliant reed to bend until the blast was passed.

* There is extant a letter from Katharine to Crumwell, expressing thanks for kiudness in reference to the Princess Mary. 'My good friend (especial amigo) you have laid me under great obligation, etc. I hope God will reward you, as you know it is out of my power to give you anything, but my good will, etc.'-B. vii., 1126.

$\dagger$ Later on Cranmer would have spared both Fisher and More, by letting them swear to the Act of Succession, and not to the preamble. But Henry objected that this would ' give occasion to all men to refuse the whole, and 'might be taken as a confirmation of the Bishop of Rome's authority.'-B. vii., 500 . 
With his sovereign he might gently expostulate, or strive by some circuitous method to modify an unjust purpose; but if all were in vain, he accounted his king to be a sort of enthroned fate, to whose will, clearly made known-and for unambiguous speaking Henry's talent was unsurpassed-he bowed with abject deference.

The friendship of Henry's two chief ministers, at the head of his ecclesiastical and his political 'jurisdictions,' remained unbroken through the strain of many perilous vicissitudes. Crumwell's voice had earnestly seconded Anne's to raise Cranmer to the primacy. Cranmer was a sincere, if a timorous, petitioner for the great statesman's life, when the malice of Norfolk and his faction hounded him to destruction. 


\section{VIII.--THE CROWN AND THE TIARA.}

THE divorce controversy was still dragging its weary length, and the gulf between England and the papacy was continually widening. On one occasion Henry directed his envoy to admonish the pontiff. 'Ye be St. Peter's successor, a fisher, who, when he draweth his net too fast and too hard, then he breaketh it, and pulling it softly, taketh fish good plenty. Princes are great fishes, and must be handled with policy.' Henry accused the pope of contravening the royal prerogative and the privileges of the realm of England, "within which, by ancient law and custom, all causes of matrimony, there begun and solemnized, ought, when called in question, to be discussed, and decided by the English Church.' As the struggle deepened, Henry asserted more and more stoutly the independence of the National Church, and his own independence as a perfect sovereign, having a right of empire in his kingdom, and recognising no superior on earth in Church or State. Yet it was only by extreme force of circumstances that he was driven to apply these principles to the solution of his matrimonial difficulties. 'I have no intention,' he declared, 'of impugning the pope's authority, unless I am compelled.' It is probable that, had Clement yielded, even at the eleventh hour, Henry would have returned in some measure to that devotion to the papacy which distinguished his earlier years. He enjoined it upon his ambassadors to "use such gentleness in talking with the pope, that he may not think our friendship so grievously wounded as that in time it may not be healed again."* Hore remarkable yet is his reply, as] quoted by Chapuys, to the argument, that he had formerly;iwritten in favour of the pope's authority. He had now, he said, 'studied the question more

$$
\text { * Letter of July 10, 1531.-B. v., 326. }
$$


deeply, and had found the contrary of what he had written to be true.' Possibly, however, they might yet give him occasion to 'study further and reconfirm what he had written.' Even Henry's logic was the creature of his strong and overpowering will. Happily for the cause of freedom, Clement persisted in his policy of weak timidity and shallow deceit. By drawing the net hard, and then softly, he suffered such a great fish as the King of England to escape from his meshes, earrying his kingdom along with him.

Sometimes the unpleasant apprehension would intrude itself on Henry's mind, and-what is very remarkable, even towards the close of the struggle-that after all he might be compelled to give up Anne. With all his doggedness of resolution, he appreciated the importance of paying some regard to the opinion of Europe; and yet more, of not too far outraging the moral convictions of his own people, whose goodwill he dearly cherished. Of course, although the negotiations passed formally between the English court and the Vatican, the real contest lay between Henry and Charles. The pope was the emperor's pupper. Thus Henry drew eloser his alliance with Franeis, who protested on his part, with national fervour, that he would willingly 'lose an ounce of blood' to write therewith to Clement in behalf of his dear brother. It was eonceived that the emperor might possibly invarle England with his forces; and the inquiry was proposed to Francis, what assistance, in such an event, in men and ships he would be able to render against the invader. The channel of communication was kept open at the same time with the Lutheran princes and cities; disaffection was nursed in Aragon and Castile; and when opportunity offered, the fidelity of Florence to Charles was tampered with. Charles, on his side, deemed it good policy to keep alive the embers of Scotch hostility to England, and to foment the chronic revolt of 'the wild Irish.' But his peculiar temper, not impulsive, but ealculating - slow in deliberation, although prompt in execution-was itself a safeguard to England against a Spanish invasion. And the Turk, now hovering on the German frontier, now approaching Vienna, threatened full employment to the imperial arms at * Letter of March 31, 1533.-B. vi., 296. 
home. Thus it was probable that the unmolested rule of his own island would still be preserved to Henry.

After mature deliberation, Clement at length (March 7, 1530) despatched from Bologna, from the very presence of the emperor - who had been crowned there February 2t, the anniversary of his birth and of his victory at Pavia-his first brief in restraint of Henry's designs. The two potentates were lodged in the palace contiguously, so that, by opening a door, there was an easy passage from the chamber of the one to that of the other. Previously, the King of England had been cited to appear at Rome by Paul Capisucchi, the auditor of the apostolic palace, to whom the cause had been committed at Katharine's request. Now he was inhibited by Clement himself from proceeding to a second marriage, under the penalty of the greater excommunication, and an interdict to be laid upon his kingdom. This inhibition was aftixed to the churches in Rome and in Flanders. Fourteen days later, to speak or to write against the validity of Katharine's wedlock was prohibited under pain of excommunication.

Shortly afterwards, the English ambassadors, as has been related, the newly-created Earl of Wiltshire at their head, arrived at Bologna, and delivered Henry's salutations to the emperor. Supported by the French ambassador, Grammont, Wiltshire prevailed upon Clement to vouchsafe some postponement of proceedings. Soon after his coronation Charles had quitted Bologna; but being referred to, he accorded his assent to the pope's petition for a brief delay. The English were now playing a similar part to that played by Katharine and her advocates, when the suit was before the legates in London. They alleged that in Rome it was impossible that judgment could be 'indifferent.' Henry, on his part, was preparing for vigorous measures of defence: he was resolved to confront papal eensures with the retaliatory force of parliamentary enactments. And Parliament, when September came, evinced its determination to uphold the crown. Henry was thoroughly in earnest. It was forbidden by royal proclamation to purchase Bulls from Rome, containing matter prejudicial to the realm, or to the king's intended purposes.* * B. iv., part iii., 6615 . 
That Parliament would follow with decisive legislation against the papacy, if need should be, at the instigation of 'the most perilous king in the world,' as Henry was called by Mai, admitted of little question.

Both sides busily endeavoured to procure the verdicts of learned men and of universities in maintenance of their cause. This was itself a step forward on Protestant lines. The English universities, after some covert opposition and much reluctance, which drew into energetic exercise Henry's imperious temper,* pronounced marriage with a deceased brother's widow to be contrary to God's law. So did the majority of the French universities. Stokesley-who, while engaged in IViltshire's embassy, had received his appointment to the see of London-remained some time longer in Italy, being directed to obtain sentences on the side of the king. Italy was considered neutral; and thus the judgments of her learned bodies were held in the higher esteem. Not only Padua, Pavia and Ferrara, but even Bologna, which was deemerl emphatically a papal city, gave sentence on Henry's side. On the other hand, Spain, and, for the most part, Germany, declared against the divorce.

English gold flowed freely. The Italians, it was said, 'will neither give nor do without money.' And when a papal mandate was issued that none should write or intermeddle in the cause contrary to conscience, through hope of reward, the decp-rooted venality of the Vatican was but little checked. The two cardinals whose influence with Clement was greatest named their price to Henry. Ancona, or 'the old man,' as he was called, required promotions to the annual value of six or seven thousand crowns and the next vacant bishopric. Ravenna, 'the young man,' Ancona's nephew, required the first vacant bishopric. Not long afterwards Ancona died; but Ravenna (Benedict de Accoltis) was actually nominated by Henry to the see of Coventry and Lichfield, and to the see of Ely in reversion.+. The emperor, on the other hand, encouraged the partisans of Katharine by ecclesiastical preferments.

* B. ir., part iii., 6343, 6325; Appendix, 254.

+ B. iv., part iii.; $\Lambda_{\text {ppendix, } 260 \text {. }}$. B. v., 777, 778, 1507 . 
The customary Roman holidays helped forward the English demand for delay; and then an interval of four months longer was solicited. Contradictory rumours had now obtained circulation. 'Boleyn,' wrote Mai to Charles, 'has lost much hope of the marriage of Mrs. Anne to the king; and the king has spent much money in buying goods and lands in support of the lady.' This was interpreted as a sign that even Henry himself was beginning to abandon hope. Others conjectured that as soon as such a considerable number of sentences had been procured as would approximate to a consensus of universities and learned authorities, the king would decisively take the matter into his own hands, and marry the lady outright, despite the pope. Clement himself was apprehensive that such a course as this would be adopted, and observed, in conversation with a French envoy, that, 'although he had had incredible pain in forcing the past delays from the emperor, yet he would grant not merely the four months' delay, but a year's delay, if they liked, provided that Henry would engage not to proceed de facto, that is, by the primacy or otherwise, and contract a second marriage.'

With Clement the Imperialists themselves were far from being well satisfied. The Cardinal of Osma, while acknowledging that he was the emperor's 'good friend,' lamented his 'secrecy, malice, and cowardice.' Katharine in her despair turned from earth to heaven. She 'must trust to God,' she said, 'to remedy evils, for she much feared that his vicar on earth did not care to remedy them.' She found the entreaties addressed to Clement by her and the emperor, that the definitive sentence might at last be pronounced, still met by paltry excuses and continued procrastination.

The pontiff's position, it must be acknowledged, was difficult in the extreme. The demands of Charles and Katharine on the one side were met by the no less importunate demands of Henry and Francis on the other. Clement was reluctant to offend either party. The English peers expostulated with him on his dilatoriness. A petition headed by the signature of Wolsey (July 13, 1530) implored him to pronounce the sentence of divorce, by his plenary authority, without legal process. In excuse of his delay, he obtruded the censures which had 
been heaped upon him by the Imperialists for what they judged to be his too great partiality towards the King of England. It had been out of his power, he said, to refuse Katharine's appeal. Above all, he complained with emphasis that no proctor had appeared before him on Henry's behalf.

But such an act of submission to Rome the pride of the King of England was resolutely fixed never to render. $\mathrm{He}$ would not for a moment acquiesce in his cause being tried at Rome. Such humiliation neither comported, he declared, with his own dignity nor with the honour of his realm. He instructed his envoy, Benet, to effect an arrangement of such a nature that the cause should be committed to the Arehbishop of Canterbury, or to the clergy of his province.* But Clement would concede nothing without the consent of Katharine. Then it was inquired whether, if the king 'should follow such means as were approved by learned men and universities in all Christendom. his holiness would forbear molesting him by censures.' What course of procedure was thus pointed at was evident beyond mistake. The French support was honestly given to Henry; and Clement was warned by Grammont that in his short-sighted obduracy he would 'see a greater ruin in Christendom than he had seen hitherto.' Clement fell into a 'great fume,' but replied with the cant familiar with him, that 'if the world must go to pieces, he had rather it did so while he was discharging his duty.' 'Threats and hard words,' wrote Benet, 'avail nothing, without an army under the king's command like the emperor's.'

Henry addressed in his own person (December 6,1530 ) an indignant letter to Clement. After alluding to the efforts of Francis in his cause, and the intercession of the English nobles, which had only encountered derision, he eharged the pontiff with abject devotion to the imperial will, and with 'ordaining, proroguing and altering things to suit the times.' Once more he peremptorily demanded that 'in England, where

* On Clement's motive in suggesting to Benet a 'dispensation for two wives,' see Benet's letter, October 27, 1530. - B. iv, part iii., 670-. For Clement's conversation with Ghinucei on the subject, see B. iv., part iii. ; Appendix, 261. 'The king wanted a dispensation,' Ghinucci observed, 'to marry within the prohibited degrees.' 
the controversy arose, it might also be decided.' He did but seek, the king maintained, to preserve what was his own. What he sought was in accordance with the laws of the Church, with the authority of councils, and with the express declarations of St. Cyprian and St. Bernard. He sought what he did because the laws of England would not suffer the contrary; and he himself abhorred contention. But he would not brook denial.*

This characteristic letter was read December 23, in a secret consistory. Afterwards Katharine's requests through her proctors received consideration. It was her prayer that his holiness would prohibit the Archbishop of Canterbury from taking cognisance of the suit, and, moreover, would prohibit the King of England, while the suit was pending, from cohabiting with any other woman, especially ' a certain Lady Anne,' and from contracting marriage. She implored also that his holiness would prohibit the said Lady Anne and all other women from contracting marriage, lite pendente, with the King of England. All that Katharine prayed for was granted.

After a long series of delays, Clement, having promised 'never again to propose a suspension,' at length issued, January 5, 1531, his second inhibitory brief. In this second brief, Henry's re-marriage, until the suit should be determined, was prohibited. Universities, parliaments, law-courts, etc., were all forbidden to venture to decide the cause under penalty of excommunication. But inasmuch as Henry had refused to admit a former citation, it was to be accounted sufficient proclamation that this brief be affixed to church gates in the Low Countries. $†$

This second brief was in gentler terms than the first, and so far countenanced the strange apology, wrung from Clement in the course of the negotiations, that he had been constrained to rigour by the majority of the consistory. Henry's letter was judged at Rome 'discourteous,' but it had not been without its weight. In a private communication, Clement remarked that, 'however bitter the king's letter, he should never forget their former friendship.' Henry, in his turn, * B. iv., part iii., 6759 .

$\dagger$ B. $v ., 2 \tau$. 
spoke of Clement as a 'good fellow' only misguided by the influence of the Imperialists. To Katharine the publication of the second brief was a cruel disappointment. In her judgment, the pontift' ought simply to have declared the pains and censures of the first brief, and then summarily required the dismissal of the obnoxious lady from the English court. The imperial ambassador commented: "It appears the brief which the pope has lately decreed is much more feeble than the first, and that his holiness is afraid that he has not the power to act according to right and justice. The English have now recovered breath, and instead of talking of sending away the lady, she remains more firmly acknowledged than ever.'

Shortly afterwards, Henry was cited by the pope's deputy to appear in person at Rome. This indignity aroused the deepest resentment, and was felt as a national insult by a large number of Englishmen, no less than by their sovereign. The only reply that Henry deigned to make was to send Dr. Karne as his excusutor. Karne was to present a 'memoir' to his holiness, declaring that the king 'could not plead by proxy in a cause on which the ease of his conscience depended ;' that it was 'not suitable for a king to abandon his kingdom to the disorders produced by absence;' and that the citation was 'contrary to the customs of the Church, and to the privileges of Christian sovereigns.' (Clement demanded that the excusator should be the king's proctor for the trial of the cause. This demand was absolutely refused. Henry insisted that Karne should do no more than excuse his sovereign's non-appearance, and claim that the trial be transferred to some other indifferent place. Thus a new controversy was openerl, which lasted long, and embittered yet more the estranged relations of England and Fome. Universities and leamed men were now called upon to determine the question which had just arisen-whether the excusator ought to be admitted or not? Those whom Henry consulted proved as eompliant with his will as before. Then the English required that a public disputation should be held at Rome on the new topic so hotly debated, and that doctors from Italy * B. v., 7i. 
and other parts should be permitted to bear a share in it. The Imperialists complained that four or six more months would thus be wasted. The result at last was, that the excusator was denied admission, both by the rota and by the consistory.

With vehement indignation, Henry declared that his treatment by the pontiff was an insult, not only to himself, but to all erowned heads. Francis forcibly adopted the same line of grievance. 'You have outraged,' he warned Clement, 'not only my brother of England and the privileges of his realm, but the prerogatives of royalty itself.' 'The question touched him,' he said, 'and all other princes deeply.'* Of the English themselves, many before lukewarm, or even inclined to favour the cause of Katharine, were drawn over to the king's side by the dishonour done their sovereign, and the contempt manifested for the statute law of the realm. A strong national sentiment, as before in Germany, was growing up in England against the pontiff's overbearing arrogance. It had stung the national pride that their sovereign should be arraigned before two dishonest papal legates in his own capital; but that, after this pretence of justice, he should be cited to Rome for the decisive sentence was an insult, they said, no longer to be brooked. Norfolk had never been hearty in advocating the divorce, but, like Suffolk and the French queen, had been in heart rather opposed to it, although he had not been avowedly hostile, like his accomplished duchess. Yet now even Norfolk felt the contumely cast upon his nation, and in the hearing of Chapuys urged that the cause ought to be remitted to England. 'If go to Rome I must,' said he, 'it shall be at the head of soldiers, with my harness on.'

With more or less energy the contest between Henry and Katharine was pervading England. Not only the baron's and gentleman's hall, and the convent refectory, but the village green, the hostel parlour, and the tap-room, were places for the animated discussion. The muns and the women generally, with the monks and friars, were the most outspoken adherents of Katharine; the Protestants were, for the most part, earnest in the cause of Henry and Anne. But beyond this immediate 
matrimonial dispute, another more vital question, underlying it, and foreed by it continually to the surface, was rising more and more into prominence. This was the deeper and more lasting question of England or Rome-the crown or the tiara?

In an age preceding magazines and newspapers, the pulpit maintained an all-absorbing monopoly of intluence. Both parties availed themselves of this common vantage-ground to enforce their arguments. Humble friars were not afraid to vociferate their censures on the king himself, as the Ahab of England. The most striking instance of the vigour and daring wherewith 'the pulpit, drum eeclesiastic,' resounded in this angry controversy may be found perhaps in a narrative given in a despatch of Chapuys to the emperor. It was towards the conclusion of the long matrimonial struggle-on Easter Day, April 12, 1532, in the memorable Observants' Chapel at Greenwich-that the provincial of the Friars Minor, by name Peto, preached before the king, and warned him to beware of that 'umbounded affection of princes and their false counsellors' which 'deprived them of the knowledge of the truth.' 'The king,' Chapuys relates, 'spoke to the provincial afterwards, and heard words which did not please him, for the provincial told him clearly that he was endangering his crown, for both great and little were murmuring at this marriage. The king dissembled his ill-will, and not being able to alter the provincial's opinion, gave him leave to go to Tholouse. When he heard of his departure, he caused one of his chaplains (Curwen) to preach there in his presence, contrary to the custom of the eonvent and the wish of the warden. The chaplain began to contradict what the provincial had preached, saying that he wished he (the provincial) were present to answer him. On this the warlen (Elstowe) rose, and said that he would answer in the provineial's absence. At the close of the sermon, the chaplain dared to say that all the universities and doctors were in favour of the divoree. The warden could not stand this lie, and said in presence of the king that it was not so. The ling was very angry. ... I Iesterday he had them arrested.' After Peto's release, he is found still busy in Katharine's cause at Antwerp, in communication with More, 
and much interested in his controversial publications, as well as in those of Bishop Fisher.**

Still more notorious, long continued, and for some time successful, was the opposition which had its centre in Elizabeth Barton, 'the holy maid of Kent,' who was for many years held in the highest esteem for sanctity. A servant-girl at Aldington, she may have been at first an honest enthusiast, like Joan of Arc. She was subject to fits, epileptic or hysterical. Conveyed at her own request to our Lady of Courte of Strette (Courthope Street), and reclined before her image, in order to be cured of ' a grievous and continual sickness,' a large crowd of as many as two thousand spectators having been assembled under the management of Masters, the parson of Aldington, her face became 'disfigured' on a sudden, 'her tongue hanging out, and her eyes in a manner plucked out and laid upon her cheeks.' A voice spoke in her 'belly, as it had been in a tun, her lips not greatly moving.' After the celebration of Mass, she knelt before the image, when she became suddenly ' whole.' Subsequently, with some pomp, professed a nun of St. Sepulchre's, Canterbury, she became a mere puppet in the hands of crafty monks and father confessors. She saw visions, and was greeted by angelic apparitions. An angel bade her go unto the King of England, that 'infidel prince,' and command him to amend his life, and to 'leave those things he loveth, or purposeth upon.' Especially was he to be warned to take none of the pope's rights from him, to destroy 'these new follies of opinion,' and, above all, not to marry Anne. If he married her, the vengeance of God would plague him, and he would be driven by his own subjects from his kingdom. Sir Thomas More was too shrewd to be an actual dupe to her prophecies; but he so far gave credit to her reputation for sanctity, that he begged to be 'numbered as one most desirous of her prayers.' Fisher was imposed upon more readily. In many hearts, it was said, she kindled a fire, which was compared to the 'operations of the Holy Ghost in the primitive Church.' She had communications with Wolsey, with Warham, with the Marquis and Marchioness of Exeter, and with others high in rank and 941.

* B. vi., 93t. Chapuys' despatch, dated April 16, 1532, appears B. v., 
office. She was admitted to an audience of Henry himself, and confidently assured him that, "if he went forth with his purpose, he should not be king seven months after.'

But this precision of prophetical date exposed her pretensions to sure detection. The faith of some-before steady and unquestioning-was already rudely shaken, when Cranmer requested to see her. Accordingly, about the middle of July, 15:33, she was eondueted to Otford by the Prioress of St. Sepulchre's. The archbishop examined her upon interrogatories furnished by Crumwell, to whose safe custody she was committed, and by whom she was treated with all respect as a 'great lady." The archbishop so far influenced her conseience that she 'desired to speak with my lord apart; and then she confessed many mad follies.' She was afterwards examined by C'rumwell. Her aceomplices were sought out by Hales, the attorney-general, in Kent, and many were apprehended. But no evidence could be extracted from the mouths of the numerous witnesses in any degree ineulpating Katharine.

After private examinations, she was brought before the council, and was severely cross-questioned. Meetings and deliberations of judges, prelates, and nobles followed. Lord Chancellor Audley reviewed the matter in an oration which he delivered to a popular audience. At length, placed on a high scaffold, together with some of her aceomplices, in front of St. Paul's, Sunday, November 2:3, 15:3:, 'the hypocrite nun ' was made the text of a sermon from the Abbot of Hyde, Bishop-elect of Bangor; after which she read her confession. She was theneeforward kept in prison, and the plot was at length thoroughly unravelled. 'Now,' wrote Cranmer (December 20, 1533), 'she hath confessed that she never had a vision in her life.' The downfall of a nefarious conspiracy was thus eomplete. Sir Thomas More begged Crumwell to inform the king of his 'true, faithful mind, and that in the matter of that wicled roman, or in anything else, there was not on his part any other mind than good.' Gertrude, Marchioness of Exeter, acknowledged her lightness and indiscretion 'in frequenting the conversation

* 'Grosse dame,' translated by Gayangos 'high-born lady.'-Sp., iv., 1153. See B. vi., 1445 . See also B. vi., 1519 , 1546 ; vii., $249,522,767$, $1149,1460,1464-70$. 
of that most unworthy, subtle and deceivable woman, called the holy maid of Kent,' and received pardon for her credulity. The opportunity of holping the royal exchequer was too obvious to be suffered to pass by. Here Cranmer was mediator with the king for the Prior of St. Sepulchre's, Canterbury. 'They think,' wrote the archbishop, 'they will offer $£ 200$ or $£ 300$ for their pardon: the monastery is not beforehand.'

The execution took place at Tyburn, with all the brutality of the times, on April 20, 1534. Such as were not named in the Act of Attainder were pardoned at 'Queen Anne's humble sute and contemplacion.' 'The detection of this widespread and long-standing conspiracy, with inevitable recoil, damaged the cause to buttress which it had been wickedly concocted.

Katharine herself was the fountain-head of the persistent resistance to the royal will. Her determination governed the emperor; the emperor governed Clement. Wight not Katharine yet be induced to consent to the decision of the cause by delegates in some other place than Rome? As early as June 6,1531 , an attempt was made, by royal command, to win her assent to an arrangement of this lind. It was about eight or nine o'clock Wednesday evening, just as the queen was on the point of retiring to rest, that an imposing body of nobles -the king's council with others-the two dukes, the young marquis (Dorset), Talbot, Northumberland, Wiltshire, the Bishops of Lincoln and London, and Doctors Lee, Sampson, and others, waited upon her at Greenwich. Norfolk was at first spokesman, and insisted upon the extreme scandal of a King of England being cited by a public edict to appear at Rome personally. To obviate such an evil, the duke suggested that Katharine should be 'content that a place and judges above suspicion should be chosen by common accord.' Henry, Norfolk declared, was entirely 'sovereign chief in his own kingdom, as well in regard to the spirituality as the temporality.' In reply, Katharine maintained that the pontiff' held ' the place and puissance of God upon earth.' Then the discussion was shared by others; and, according to a barbarous characteristic of the age, it soon deviated into the well-worn track of. the question of consummation. Talbot alone acted 
and spoke in the spirit of a gentleman, not failing to remind the rest that they formed almost all the nobility of the kingdom, and ought to act as became their name.* Katharine remained inflexible as ever.

When, a few weeks later, the king removed altogether (.July, 1531) from her, she remonstrated with him by letter, that he had even denied her the consolation of bidding him adieu. His reply was delayed a short time; but after three days a letter was sent to her without any address, probably, Chapuys suspeeted, 'beeause they mean to change her name.' In eold and severe terms this letter upbraided her with the falsehood of denying the eonsummation of her first marriage. A little later (August 19), under the pretext of hunting about Windsor, the king commanded Katharine to retire thence to the Moor in Hertfordshire. The princess he sent to Richmond. But such studied attempts to break Katharine's resolution proved as ever quite ineffectual.

In the autumn (Oetober, 1531) there was a further trialand now milder measures were essayed - to shake her firmness. A small and select deputation-Lee (elect of York), Sussex, Fitzwilliam (the treasurer), and Dr. Sampson-waited upon her by the king's command, and entreated her, instead of letting 'the cause proceed according to the rigour of justice,' to leave the verdict to 'the bishops and doctors of the kingdom.' But, unchanged as before, she would hear of no compromise. She now knew, she sairl, that the king was not moved by any seruple of eonscience, but by mere passion: and in England, she averred, everyone 'for fear or subornment, was ready to eall black white.' The deputies fell upon their knees and implored her to consent that the cause be decided here. She in her turn fell upon her knees, and entreated the deputies, 'for the honour of God and His passion,' to remove such a scandal from Christendom, and persuade the king to return to her, for 'he knew that she was his true and lawful wife.' $†$

The overwhelming sorrow which she endured-three weeks later than the last interview referred to-was poured out by her into the confidential ear of her imperial nephew: "My tribulations are so great, my life so disturbed by the plans

$$
\text { * B. v., } 287 \text {. } \quad \text { B. v., } 478 \text {. }
$$


daily invented to further the king's wicked intention, the surprises which the king gives me with certain persons of his council are so mortal, and my treatment is what God knowsthat it is enough to shorten ten lives, much more mine.'

Katharine was unconsciously, although a negative, an eminent means of bringing about a revolution of stupendous moment. It is impossible to forbear admiring the dignified self-respect which never failed her, and equally impossible to omit to detect, through varied negotiations, the signal, secret hand of Divine providence. Her obstinacy, reproduced in her daughter, in whom it was set down to her 'Spanish blood,' although in her hard face and strong voice there was a clear trace of her fatber also, drove Henry, in order to compass his unbending will, to deliver the Anglican Church, quite against the grain of his earlier habits and associations, from its galling serfdom to Rome. He placed himself, instead of the pontiff, at the head of an ecclesiastical system thus made purely national. Great were the beneficial results; yet the revolution was attended by fears, and by some real dangers. Among the dangers, the attitude which Henry would take up in reference to Church property was not the least. The payments, previously made from Church incumbents to Rome, under the altered circumstances, were diverted into the royal exchequer. And it even became doubtful whether the claim to the sum total of Church possessions, sometimes advanced on the pontiff's behalf by the fanatical adherents of the papacy, might not be distinctly realized by Henry to his own emolument and increase of power, when he had surmounted his crown with the tiara. That the Church should have become a mere stipendiary of the State would have been disastrous to both. Happily, better counsels prevailed.

How an all-influential revolution was brought to pass, and the supremacy of the crown was substituted for the foreign: domination of the pope, will now be very briefly told. The providence of God eminently watched over England at a most critical juncture. The ecclesiastical machinery was retained; the fabric of Church society remained unimpaired; and that breach of continuity which has weakened the Reformed Churches of the Continent was wisely averted. There are 
indications that the desire of an alliance with the German Protestant princes might have even disposed Henry to break with the past, and adopt the Presbyterian form of Church government. This would have been a grievous error. But this danger, too, was averted. The heartiest thanks are due to wisdom above man's for what was not done, as well as what was done. It is even more than an ornament to a national Church to trace back her lineage to the primitive institution. Few, if any, more striking instances appear in the records of a nation's bewildering risks and merciful deliverances-not only of the worst evils being rendered subservient to the greatest blessings, but also of a revolution, in its chief feature radical, being carried through with conservative caution-than that furnished by the history of our own Reformation. 


\section{IX.-THE CONFLICT DRAWING TO AN END.}

IT would be lengthy, even to tediousness, to track to the end the dilatory course of the matrimonial negotiations, whether at Rome or elsewhere, through a recurring series of demands, evasions, procrastinations, complaints, recriminations, proposals for the transfer of the cause to some neutral spot, proposals relative to a general council, fears, hopes, regrets, disappointments -- a labyrinth tangled and intricate almost beyond example. It must be enough to indicate some of the concluding events.

At length a third brief, which the Imperialists had long: petitioned for in vain, was signed by Clement, November 15, 1532, just after Henry and Francis had met at Calais, and when the pope himself was on the point of leaving Rome to meet Charles at Bologna. This third brief threatened Henry and Anne conditionally with excommunication, unless within one month the king should put away Anne and take back Katharine. But even before the publication of this third brief, it was expressly enjoined upon the nuncio to see and confer with Henry-a compromise which blunted the edge of papal severity effectually. The presence of the nuncio was paraded in both Houses of Parliament, as though there were yet some secret hope lingering that the crown and the tiara would be able to accommodate their differences after all. Proofs abounded that Clement was as reluctant as ever to break irrevocably with a sovereign who had formerly been his most devoted ally.

But the close was now near at hand. It had been rumoured that Henry would marry Anne, at his October meeting with Francis, at Calais. But although the French king danced 
with the Marchioness of Pembroke, as Anne had now been created, yet, careless as he was in regard to morality and even deeency, he would not have been willing to go such lengths as to eountenance publicly by his presence the marriage of Hemry with his beautiful mistress, despite both pope and emperor.

In the next spring, however, Cranmer was eonseerated to the primacy. High oftice had been known to ehange the opinions of some who had been advaneed to it, as had been reeently remarked of Lee and of Gardiner. But no such change could be apprehended in Cranmer's ease. That the new arehbishop would be unhesitatingly subservient to the king, and would zealously eo-operate with Crumwell in earrying out a national eeclesiastical policy, were points already thoroughly ascertained. The marriage therefore at length took place, although the eeremony was performed in seeret by Roland Lee, a royal ehaplain recently appointed to the viearage of St. Sepulehre's, and afterwards (Mareh, 1534) Bishop of Coventry and Liehfield. The date of the marriage was either late in 1532, or 'about St. Paul's Iay' in the opening year. The latter is more probably the eorreet date, inasmueh as it is supported by a statement of the arehbishop.* In the middle of Mareh, Anne's brother was despatched to Franeis to inform him of the event, which had at last been brought to pass in accordance with his fraternal advice, and to add the intelligenee that there was already a happy promise of suceession to the throne from the auspicious union. The King of England assured his ally and brother that he trusted to his firm friendship to uphold the legitimaey of his ehild.

How ready Clement was to oblige Henry, when he could do so without offending the emperor, was shown by his eonfirming Crammer's election by the Prior and Convent of Christ Chureh, and by his granting the Bulls for his elevation to the primacy without any objection or delay. As soon as the Bulls had arrived, in the end of Mareh, Henry forthwith submitted his divorce question to the deeision of Convocation. Fisher alone had suftieient courage to speak in Katharine's defenee. But eighteen votes only were added to his own, in support of the * B. vi., 661 . 
pope's dispensing power. Thus the king's majority was overwhelming. On the topic of consummation, only tive or six upheld Katharine.* That the sanction of the divorce by Convocation would be followed by its sanction by Parliament was of course certain, and that the marriage was actually declared 'null' by Parliament is stated in a despatch of the Venetian ambassador, yet no record of the vote is extant in the Statute Book.

It seemed like a dream to the people when, on the morning of Easter Eve (April 12, 15:33), Anne went to her 'closet (pew)' to hear Mass in regal state, "clad in cloth of gold, and loarled with the richest jewels.' There were even preachers-notably Dr. Browne, Prior of the Austin Friars-who invited their congregations to pray for her as queen. But in some such cases the result was immediate disorder, and the symptoms of popular displeasure were so distinct that Henry, a keen observer of all that was passing, was induced to send for the lord mayor, and bid him issue his order that the citizens must not murmur at the royal marriage, and, further, must rule their apprentices and their wives.

It next devolved on Cranmer, as 'the principal minister' of the stern autocrat's 'spiritual jurisdiction,' to pronounce the wedlock with Katharine invalid and void trom the beginning. Accordingly the archbishop opened his court (May 9) in the monastery at Dunstable. 'This was a 'solitary place,' notes Chapuys, 'chosen for secrecy.' Longland and Gardiner were the archbishop's assessors. 'The Lady Katharine' had been removed from Buckden, near Huntingdon, which she disliked as appertaining to the see of Lincoln, the bishop whereof was Henry's father-confessor, and which she complained of as 'damp in the winter,' and had been drawn nearer to the Metropolis, first to a house of the Bishop of Ely, only seventeen miles from London. Then in September, 1532, her letters are dated from 'Enfyle' (Enfield), and in November from 'Artford' (Hertford) Castle. She even began to nourish some flattering hopes that God had inspired her husband to

* B. ri., 296, 311, 317 ; Ven., iv., 870. The Venetian ambassador adds, 'On Palm Sunday be (Fisher) was arrested, and given in custody to the Bishop of Winchester.' 
'acknowledge his error.' This whisper of hope was altogether delusive; Henry was only completing the tinal steps of his cruel policy. For suddenly-March, 1533-Katharine was ordered to Ampthill, a royal manor four miles from Dunstable. When Cranmer opened his court in this quiet and sequestered country town, the drift of the royal purpose became apparent.

Katharine declined, with her customary dignity, to present herself in court, maintaining that her 'cause was before the pope, and she would have no other judge. Her non-appearance was no inconsiderable relief to Cranmer's harassing fears, and enabled him to accelerate the legal process. For the populace, for the most part, remained stanch in their attachment to her cause and person, many even estceming her a saint and a martyr.

At Lambeth, May 28, Cranmer pronounced that Henry had actually married Anne, and that the marriage was perfectly valid. To this sentence Crumwell was one of the witnesses. The coronation followed immediately. Whit Sunday (June 1) cranmer, with all pomp, anointed and crowned Anne in Westminster Abbey - the magnificence of the coronation being in marked contrast to the secrecy of the nuptials. The king availed himself of all that power could command, or wealth purchase, to surround his mistress with every sign of honour and popularity; yet few heads uncovered, few voices cried 'God save the queen,' as Anne passed along in a chair of cloth of gold, between two mules, herself elad in silver tissue, her hair hanging in luxuriance over her shoulders, and a crownlet on her head.**

The queen's jewels already adorned the person of Anne; the queen's barge, also, had been appropriated for her use; and now it was determined to invest her with the title of queen, to the exclusion of Katharine. A proclamation was therefore made (July 5 ) in various parts of the metropolis, and then printed and aftixed to the walls, that Katharine was to be styled simply 'princess dowager,' under ' the great pains and penalties' of pramunire.t Pressure was also put upon her personally to bend her will to her altered position in regard to the title which she was thenceforward to bear.

$$
\text { * Ven., iv., 912. † Yen., iv., } 933 .
$$


The account of her unwavering firmness when, lying on a pallet, having pricked her foot with a pin, and suffering in health from a severe cough, she was confronted by the commissioners with their 'paper of instructions,' has been so often narrated that it need not be repeated here. Her domestics emulated her resolution.* They maintained that they had taken the oath to her as 'queen.' Her chamberlain, Lord Mountjoye, found the difficulties of his post so embarrassing that three months later he requested of Crumwell permission to resign it.

The contest, illustrated by traits of character, noble and base, was now at last, with rapid progress, drawing on to the definitive issue. Forewarned, England had been forearming against Rome. In the Articles prefixed to the Book of the Subsidy, granted by the clergy under their technical guilt of præmunire, an acknowledgment of the king's supremacy had been inserted, with prudent forethought, in terms so clear and distinct as to admit of no altercation whatever. Such scruples as might yet linger in some minds were promptly silenced by the king's unyielding tone and peremptory manner. A conference was held in Convocation (February 7, 1531), touching these Articles, and the general pardon of all the premunire offences. Henry exhibited his characteristic vigour and outspoken determination. Forecasting ulterior events, he claimed the title of 'sole protectur and head' of the Anglican Church. Convocation added-discarding all concern for the pope, and occupied with the vital interests of the National Church itself alone-the important modification, 'after God' (post Deum). This addition the king acknowledged without any reluctance; and then he declined further discussion. Accordingly, on the motion of Warham (February 11), the king was declared unanimously 'the only sovereign lord and protector of the Church of England, and, as far as allowed by the law of Christ, supreme head of the same.' + 'This recognition of the royal

* See B. vi., 759, 760, and 'The Report of Lord Mountjoye, Richaril Gryffytb, and the others, of such Answer as the Princess Dowager made unto them at Ampthill, the Friday, th day of July (1533).'-B. vi., 765 and 1252 .

† Hujus cleri et ecclesiæ Anglicanæ dominum ac protectorem singularem, ejusque unicum summum ac supremum caput, quantum per 
supremacy, as existent from immemorial time, is very valuable. It was made with all due formality by both Houses of Convocation, without a single dissentient voice, Warham, Gardiner, and even Fisher, it would seem, assenting to the vote.*

The next year Parliament became the principal arena for debate. Mutterings of discontent were not quite suppressed in the Commons when, in the spring of 1532, Henry demanded supplies to strengthen the Scotch frontier. Some even ventured to suggest that the more effective mode of protection would be that the king should take back his queen. One member, according to Hall, suggested a petition to the king for this very end. No weak-minded Stuart, however, was seated on the throne at this juncture; but a resolute Tudor, with that clearness of purpose and faculty of command which went with the strong blood. Henry simply sent for the speaker of the House, and forcibly expressed his unchangeabie resolve. The speaker was now the specious trimming Audley, who much ingratiated himself at this time with the king by his dexterous handling of the Commons in entire subservience to the royal will. Henry declared to Audley his surprise and astonishment that any member of the Commons' House should presume to moot a question which touched their sovereign's conscience.

The Act passed (March 19, 15:32) 'in restraint of Annates,' or first-fuits of bishoprics and bencfices, significantly marked that mixture of craft with determination wherewith Henry was pursuing the fierce struggle against Rome. He was hypocritical enough to feign that he simply yielded to the

Christi legem licet, regiam Majestatem agnoscimus et confitemur.'-B. v., $112,14 !, 128$.

* See 'The English Church under Henry VIII.,' by W. E. Gladstone, Ninetenth Century, November, 1889, pp. 882-896.

In the northern provinee 'Tunstal made a protest agains the new supremacy. He was solicitous lest the king should trample on the liberties of the National Chureh. Henry, in reply, retorted on Tunstal the argument he had used in the divorce question, "Why do not you conform your conseience to the eonseience and opinion of the greater number?' - B. ₹., 819, 820. Wilkins dates 'Tunstal's protest 1533. Gairdner, 1531.

'Considering,' wrote IIenry, 'what the Chureh of Rome is, it is no schism to separate from it, and adhere to the Word of God. . . . To follow the pope is to forsake Christ. God willing,' he added, 'we shall never separate from the universal body of Christian men.' 
force of general opinion in sanctioning this Act. But it was, in fact, by his personal action, and through 'fear of his displeasure,' that the Bill became law. It was a scourge wherewith to smite the papacy in a very tender part, and was exactly adapted to the royal hand. For 'the Act was to have no further validity than the king might give to it by letters patent issued before Easter, 153:3, or before the next meeting of Parliament.* The king himself was empowered to compound with the pope in regard to payment for Bulls.

To the Commons' Petition aguinst the Ordinaries, a reply had been drawn up with conspicuous ability, by no other hand, it would appear, than Gardiner's, who confessed to having corrected it. An exculpation was appended by Warham, relative to his own conduct in his high office. The opinion entertained respecting Gardiner, by Katharine's party, was fast changing; and he now began to be spoken of by them with some approach even to favour. 'Previously,' wrote Chapuys to Charles, 'he was suspected of opposing the queen; but now it is believed he will do her all good oftices.' On the other hand, by his altered demeanour and apology for the Ordinaries, the bishop was incurring royal displeasure to a serious degree. In a letter to Henry he attempted to sustain his positions by referring to the arguments of the king's own book against Luther. In much repute as a canonist, Gardiner humbly professed himself to be but little learned in divinity. And in order to mitigate yet further the royal ire, he absented himself for some short space from attendance at court, alleging that he was 'letted by disease of body.'

The Reply Henry placed in the speaker's hands, not failing to intimate at the same time his estimate of its merits: "It seemeth to us very slender.' He now demanded that the clergy in their own spiritual sphere should enact no new canons or 'constitutions provincial' without the royal assent and authority, and that they should give their consent to the

* 23 Henry VIII., c. 20.

Chapuys wrote, March 20, 1532, the day after the passing of the Act, 'The king has been at the Parliament three times lately, and so played his part that the Article about Annates has passed.'-B.v., 7-20, 721.879, 898 .

Henry gave validity to this Act July 9, 1533; and two years later the Act was made absolute. 
revision of those already enacted. Convocation had been accused in the Commons' Petition of decreeing laws 'contrary to the laws of the realm.' The mood of the clergy was, outwardly at least, pliantly submissive to the royal will. Thus, notwithstanding much real dissension and bitter secret heartburning, the brow-beaten prelates were constrained to bend their necks to the firm yoke of their sovereign. The submission of the Clergy was at length-May 16, 15:32-presented to Henry at Westminster.* Trampling down all obstacles, Henry and Crumwell had conquered. But the king continued in very angry mood, as Chapuys informed the emperor. The lord chancellor and the Bishop of Winchester were especially the objects of his wrath. 'Churchmen will now,' murmured the imperial ambassador, 'be of less account than shoemakers.'

The very same day that the Submission of the Clergy was presented (May 16, 1532), Sir Thomas More, who, noting the course of events and the tendency of lay opinion, had for some time sighed to be released from official trammels-quite heart-sick at last at the establishment of what he called 'the new papacy here,' and foreseeing that his retention of othice must spread a net for his conscience-resigned the great seal. The resignation was made in person to Henry himself, 'about three p.m., in the garden of Iork Place.'

Chapuys stated that, in excuse for the resignation, were alleged too small 'entertainment' and failing health. That as lord chancellor More had worked hard is certain; for he left no arrears when he quitted the Chancery-a triumph of conscientious industry without precedent. Moreover, in his own brief autobiography, in his epitaph, allusion is made to pulmonary weakness. But to murmur at the insutticiency of the salary, small as it was in real truth, was not like More. Yet the loss of the full salary, such as it was, was a heavy drain on his financial resources. Roper recounts how his fatherin-law contemplated with amused composure the necessity of

* 13. v., 112:3. This Submission, two years later, was formulated into 2.) Henry Vill., c. 1!!.

This Ict reconnts in the commencement, that the clergy 'bath promised in verbo Sucmolii, that they will never from heuceforth presume to attempt, allege, claim, or put in use, or enact, promulge or execute any newe canons, etc. . . onles the king s most royal assent and licence, etc. 
returning to 'Lincoln's Inn diet,' or of even descending to 'New Inn diet,' or, meaner still, to 'Oxford fare,' or, meanest of all, of betaking himself, together with his family, to mendicancy. His merry humour again broke through the gloomy forebodings of outward circumstances, when he would inform Mistress Alice of the unworldly step which he had adopted. 'One of his gentlemen, when service at Church was done, ordinarily used to come to my lady his wife's pew-door, and say, "Madam, my lord is gone." The next holiday after the surrender of his office, and departure of his gentlemen, he came unto my lady his wife's pew himself, and, making a low courtesy, said unto her, "Madam, my lord is gone." "When she came to apprehend the actual fact. of the resignation, Mistress Alice was beyond measure vexed and irritated: 'Tillie Vallie! Tillie Vallie!' like Dame Quickly she exclaimed, 'will you sit, Mr. More, and make goslings in the ashes? My mother has often told me, "Better rule than be ruled." " Iore noted with some gratification, in a letter to Erasmus, that Norfolk was commanded to speak in honourable terms of him at his successor's installation, and that his successor also was directed to commend him.

Four days after More's resignation Henry committed the great seal to the keeping of Sir Thomas Audley, who had succeeded More as speaker of the Commons and also as Chancellor of the Duchy of Lancaster. This transfer was a merciful reprieve to the poor Protestants, to whom the smooth, unscrupulous Audley was not unfiavourable-a sign that Protestantism was rising into fashion. But Audley was not appointed lord chancellor until eight months later ; for it was deemed expedient to retain him in the House of Commons, where his services had been valuable to the $\mathrm{king}$, and were likely to be valuable again.

It appears that More was allowed to retain some portion of his former salary - at least, until he fell into deeper disfavour at court. That a salary in itself small shonld have thus become further curtailed may serve to explain Audley's complaint, on his own behalf, to Crumwell, that 'never had chancellor so little to live by,' and that, too, at a time when victuals were

$$
\text { * B. r., } 1075 \text {. }
$$


so dear.* The king was desirous that More's presence should grace Amme's coronation, and thus countenance his new nuptials; and he therefore presented the ex-chancellor, through the medium of some of the bishops, with $\mathfrak{2} 20$, wherewith to purchase a gown in which to attend the festive ceremonial. But reduced as his fortunes were, Hore declined to receive this gift; nor is his name entered among those present at the coronation. After the detection of the conspiracy which centred in the Holy Maid of Kent, More was subjected to an examination before Audley, Crumwell, and Cranmer, respecting a letter which he had written to her. This letter, however, only contained the sensible advice that she should leave affairs of state, and give her attention entirely to devotion. In a letter to Crumwell, the ex-chancellor protested: 'Never shall there loss in this mater greve me, being myself so innocent, as God and I know me, whatever should happe me therein.' +

Henry was thus unable to fasten even a suspicion of guilt, in connection with that artful plot, upon More. Yet a letter of (hapuys, not long afterwards, contains the intelligence: "The King, not finding "an occasion for doing him more harm," has taken away his salary.' With this loss, More escaped for the time being. But he found that the world insults the poor ; for he had to address to Crumwell, through Fitzwilliam, the complaint that 'since he resigned the chancellorship, a gentleman had treated him very ill.' + He was still, however, in better plight than his equally courageous friend Fisher, who was mixed up with the legal condemnation of the Nun of Kent, and had been declared guilty of 'misprision of treason.'

The passing comments of the ouservant and vivid mind of the imperial ambassador have much enriched our knowledge of the history of a most interesting period, and by their revelations of the actual or suspected condition of England, as well as of the imperial deliberations and counsels, furnish matter for important reflection. Although a Swiss, Chapuys equalled in his attachment to the emperor the most devoted Spanish hidalgo. Of the English, he everywhere writes in his

$$
\text { * B. vi., } 427 . \quad+\text { B. vii., } 265,2 \times 7-90,296 . \quad+\text { B. vi., } 762 .
$$


despatches in terms of supercilious contempt. He describes those amongst whom he was sojourning as a 'credulous and simple' race, whose ill qualities mildness aggravated and harshness subdued. He urged with all his eloquence the invasion of England by Charles. 'Two or three thousand Frenchmen' had sufficed for the overthrow of Richard on Bosworth Field. With far greater ease would Henry, more detested by his subjects than even Richard, fall at once a prey to a sovereign so powerful as was Charles, and perfectly adored by his Spaniards. Such suggestions and arguments were seconded by Ortiz, Katharine's proctor at Rome, with no less fervour. Chapuys and Ortiz joined their earnest entreaties, that 'the public sin' of the English monarch might be visited with condign punishment. The pope must devote England, of old his feudatory - King John having surrendered the kingdom to Innocent III., and received it back in fief-to utter destruction, and then call upon the emperor to be the executioner of his will and sentence. How could Englandin a corner of the world, her traffic in wool with Flanders her chief maintenance and stay-resist the colossal resources of Spain and the empire?

As the deliverance of England from the Roman yoke drew nearer and nearer, the demands for the invasion of the rebellious island became more frequent and more energetic in tone. But sager counsels prevailed when the question came for calm deliberation before the emperor himself.* It was reserved for another generation of Spaniards, and for a son much inferior to his father in ability, and not only of less vigorous intellect, but of yet narrower religious prejudice, to point the irony of history, and, turning to be the foe of the Protestant queen, to launch that invincible Armada which proved a sport to the elements, or perished by the gallantry of Howard and Drake, if not driven in unwieldy ruin on the rocks, under a mightier vengeance than man's.

* B. vi., 568 .

Yet the instructions of Charles V. ' to Cifuentes and Rodrigo d'A valos' contained the following, "You shall also consult on the best means of forcing the King of England to put away his concubine; and, if possible, getting his boliness to deprive him of his kingdom, which he holds of the Holy See, as the Acts lately passed in England against the authority of the Holy See give cause to fear that the king and Anne Boleyn will care little for an interdict, etc.'-B. vi., 570 . 
'Truth,' Gardiner would sometimes say, 'is called Time's daughter: Time will have ehild at the last, but it is long first. I would Time's deliverance were as speedy in childing of Truth as conies be, that bring forth every month.' 'Time has now run her course sinee such words were written, three hundred and fifty years! What is the outeome of Time's revelations? Survey Spain and England in their present condition-the mature issue of cause and effeet through so extended an interval. The sunny land of Ferdinand and Isabella, of Charles and Philip, is no longer dreaded for her might by sea or land, although still admired for the ample bounties lavished upon her by Nature. Her armies-the finest infantry in Europe-her great captains, her invincible armadas and magnificent admirals, have long sinee ceased to be matter for national boast and world-wide talk. As a military or naval power, Spain is nowhere now. Her transatlantie glories are vanished. What remains is a soil that might teem with rich abundance, but the capabilities of which are, for the most part, wasted through indolenee and deficient cultivation. Dwindled to a fourth-rate kingtom, effete Spain, in the cuuncils of Europe, no longer utters her voice-feeble as in seeond childhood.

In the same interval, "the weather-beaten island in a northern sea,' with a population in Henry's reign of only three millions and a half, has grown into Great Britain. Scotland, formerly a thorn in her southern rival's side, has beeome one with her. The mutinous Welsh, without representatives in Henry's Parliament, are now law-abiding, and fully represented in the imperial deliberations. Ireland, indeed, of which the Venetian report in Henry's day declared that the inland inhabitants 'wore under their doublet a shirt steeped in saffron on account of the lice,"* continues to be squalid, wild, and intractable, chiefly through the influence of inveterate popery, for the Protestant northern portion of the "Emerald Isle' is as industrious and flourishing as England. Augmented immensely in population as is Great Britain herself, India and the Greater Britain beyond the seas embrace vast populations little short of three hundred millions in the aggregate.

$$
\text { * Ven., iv., } 694 .
$$


The sons and daughters of Britain, year after year, are filling the void places of the earth. A commerce unprecedented in extent and value distributes throughout the globe marvellous products of manufacturing energy and skill of various sorts, with the result of ever-expanding national and private wealth. English fields and acres-so considerable is the progress of enterprise and improvement-wear the trimness of a highly cultured garden. A language vigorous and incisive, a national heirloom from Shakspere and Nilton, is becoming more and more the accepted universal tongue. Last, not least, our Anglican Reformed Church is pushing her way beneath the equator and beyond the tropics, and is emulating the English people in vitality and growth.

A change which amounts to a reversal - -and, indeed, almost immeasurably more than a reversal-of the relative positions of the two kingdoms, in the interval of three hundred and fifty years, can only be explained by causes penetrating to the very depths of motive and character. Doubtless it is under the blight of Romanism, under the curse of the black functionaries of the Inquisition and the cramp of enslaving despotism, co-working with priest and monk to national degradation, that Spain has so miserably lost her place in the scale of nations, and has sunk with a decline signal and total - which, unless the causes are effectually removed, must inevitably be final.

England, on the other hand, has flourished by an open Bible, by free Protestant thought, by political and civil liberty, by the personal independence and energy which have grown and developed under the safeguard of a Scriptural creed. It is the Protestant heart, beating strong in the national breast, which has been the true secret of Great Britain's becoming the widest and greatest empire of which history has any cognizance. The rugged absolutism of Henry, the obstinacy of Katharine, the impetuous ardour of Anne, the gentle, timid wisdom of Cranmer, the ribaldry and calculation of Crumwell, the vacillations and duplicity of Clement-all contributed, under the overruling hand of a merciful Providence, to results lasting in their blessedness and world-wide in their extent. 


\section{X.-THE FINAL SEVERANCE.}

IT was a fine eonception of Hobbes, that papal Rome is as " the ghost of pagan Rome, sitting erowned upon the grave thereof.' In extending her empire she had employed artifices which her predecessor had found efficacious before her. Whether the papaey be regarled as a spectre of past grandeur, or as a living reality, although she bears ineffaceable scars of terrible wounds, her potency still survives. Her dominion is the most subtle and mysterious in man's history. Even from calamity she has drawn the elements of renewed vigour. And here, too, the resemblance is striking between Rome pagan and Rome papal.* No words are sufficient to express the gratitude due to the Almighty, that as regards England, He has taken from the lips and dashed to the ground the 'golden eup' of the great sorceress.

Against the weird papacy Henry was engaged in the elosing bitterness of a protracted struggle. He did not claim to exercise spiritual functions; but he was now the acknowlerlged head of both his 'jurisdictions,' the spiritual as well as the temporal. He was master of Parliament, and sovereign

'Per damna, per eedes, ab ipso

So IJorace sang of pagan Rome.

Ducit opes animumque ferro.

of papal Rome Archbishop Trench has written: "Where wonld the Romin Catholic Chureh be now, exeept for the great searchings of heart, the diligent setting of her house in order, the strengthening of the things which remained, which all by this visible judgment act (the Roformation) were forced upon her" Matters had eome to such a pass, ills had become so inveterate, that it was no more possible for her, of a free spontaneous impulse, to have reformed herself, than for a man to perform a painful surgical operation on his own body... B By the Reformation ... she recovered mueh that for a while appeared to be lost to her for ever.'-('Medieval Church History,' pp. 426,427 .) 
with absolute sway of his ancient kingdom. Personally he was fully equipped, and by character and determination admirably adapted to carry on the conflict with success, to the entire emancipation of his people from the oppressive yoke of a foreign spiritual tyranny. For this purpose all the resources of his nation and of his Church were concentrated in his single hand.

The negotiations had been lengthy, the strife long continued; but the royal mind was now reaching a clearer decision, and the final severance was to be accomplished with less delay.

Nenace answered menace, blow met blow, and England stood prepared to receive and to retaliate the final stroke. Appeals to Rome, in testamentary, matrimonial, or ecclesiastical causes, were prohibited. Every 'spiritual pastor' was required to 'minister the sacraments and Divine services,' notwithstanding any 'fulminacions' of the pope, on penalty of one year's imprisonment.* This corollary to the Royal Supremacy, known as the Stutute of Appeals, was not only a precaution in the event of the apprehended interdict, which - the pope being 'in no such credence as once he was'had lost the chief part of its terror, but, added to the Submission of the Clergy, it helped to lay the basis of the new ecclesiastical system.

Yet Rome and St. James' did not desist from negotiations.

Henry and Clement frowned and wrangled, but even yet loitered over the final separation. Almost to the very last they parleyed, as though they might even yet come to terms. Henry on his part, if he could only receive contentment in his 'just and weighty cause,' professed himself still well disposed to renew the old amity. And thus the Act forbidding the payment of 'pensions, censes, porcions, Peter-pence, or any other imposicions' to the pope, and the 'suing for any dispensation or licence to the See of Rome,' $\dagger$ which seemed to dissever finally the last tie that could remain to bind England with even a tattered shred to the papacy, was made conditional with ostentatious caution. On this side the Feast of the Nativity of St. John Baptist, the king's majesty was empowered to annul it.

$$
\text { * } 24 \text { Henry VIII., c. } 12 \text {. † } 25 \text { Henry VIII., c. } 21 .
$$


Clement, on his part, exeommunicated Henry, July 11, 15:33,* and declared his divorce and new marriage illegal. Yet all this, likewise, was only conditional. If before the end of September Henry would repudiate Anne, and take back Katharine, the papal sentence was not to be divulged. But no such results as Clement desired followed the suppressed sentence, and therefore, November 19, it was published at lunkirk.

It was in November that Clement met Franeis, not at Nice, as had been proposed, but was entertained by him as his guest at Marseilles. This meeting, when it seemed likely actually to come to pass, was opposed by Henry, so far at least as it eould be guardedly opposed with any remaining semblance of courtesy. 'If the pope,' he urged, 'persists in proceeding against us, no good ean come from his interview with the French king. To all his attempts to revoke what is done here, we shall say $N a y$ in such a sort that the world shall hear, and the pope shall feel it.' But Franeis had purposes of his own to mature and aceomplish at this friendly eneounter. He still eherished designs against Italy; and he was especially desirous of completing the negotiations for that marriage of his son, the Duke of Orleans-afterwards Henry II. - with Clement's niece, Katharine de' Medici, whence, in after-years, ensued eruel and fatal evils, aggravater or produced by the wickedness of a woman who took the Borgias as her pattern, and Machiavelli as her prophet. Francis, however, had promised to exert his best efforts in his royal brother's cause ; and like his ambassador Grammont at liome, so he, too, kept his word at Marseilles. But to his extreme surprise, on Friday, November 7, an English envoy, Bonner, presented himself, together with Gardiner and Vannes, before his holiness, and read aloud the 'Appeal of the King of England to a General Council.' Clement 'pulled down his head to his shoulders,' after the Italian fashion, and manifested other signs of excessive annoyanee. Francis, too, was chagrined beyond measure. It seemed a breach of the aceustomed deferential courtesy between monarchs, that when Clement was on French soil, the guest of Francis, he should

$$
\text { * B. vi., } 807,958,144 \text {; ; Ven., iv., } 945 .
$$


on a sudden be taken by surprise, and have an appeal to a higher authority against his own sentence, presented to him by an ally of the monarch, who was hospitably entertaining him. Certainly Henry's appeal marked plainly, with characteristic roughness, his dislike and suspicion of the conference. The strangest and least defensible part of the King of England's abrupt behaviour is the small concern it evidenced for giving umbrage to his ally, who was thereby placed in a very awkward position, and was obliged to dissemble as well as he could his vexation, as well as his ignorance of his royal brother's intention. But Francis smoothed down the asperities of the unpleasant incident with all the adroit self-possession possible. He whispered to Clement that his ally and brother must be a 'madman,' and at this period Henry was pursuing his purpose with a force that seemed to ordinary judgment to border on madness. At home, throughout the winter of 153334 , in disputations and in sermons, the usurped power of the 'Bishop of Rome,' by royal command, was made the general theme of declamation and discussion.

From this point of time the steadfastness of the fraternal compact began to relax somewhat the strain of its intensity. But the brotherly understanding had been maintained in full force sufficiently long for its principal end, from Henry's point of view at least, to be effectually answered, and the emancipation of England from Rome's thraldom to be virtually already consummated. Clement had been ever forbearing and mild; still vouchsafing Henry leisure for reflection and penitence. Henry, on his side, had been continuously active in inducing Parliament to pass enactment after enactment against the papacy, at the same time that every measure had been studiously made conditional. The English people without reluctance put weapon after weapon in his hand, to tse at his own discretion, in what, in its ultimate issues, was the cause of the nation. 'Our subjects,' Henry wrote to Wallop, his ambassador with Francis, 'considering the injuries we have received, have required us no longer to endure the attempts of the pope, but to find some remedy for them by a total abolition of his authority; and in so doing to obtain the advice and assistance of the princes of Germany. We have 
in consequence taken such order with our nobles and subjects that we shall be able to give such a buffet to the pope as he never had before.**

At length the moment for the final severance came. 'The bolt, suspender for months and years in the sky over England,' fell at last. Clement authoritatively pronounced, Monday, March 2:3, 1534, the union of Henry with Katharine valid. Henry, on the other hand, was quite even with the pontiff. Parliament had been so packed-the attendance of bishops and peers favourable to Rome having been countermandedthat the legislature appeared to be absolutely at one with the sovereign. In conclusion, therefore, of the protracted struggle, the menorable Act of Succession + was passed, which gave validity to the divorce, and legalized the marriage with Anne. Let the pope by brief or Bull proclaim what he would, Henry and Anne were now man and wife 'by the sure knot of act and statute.' At the end of March Parliament was prorogued. Everywhere from one end of England to the other, during the spring and summer, commissioners were busily engaged in receiving signatures to the settlement now authorized by Parliament.\$

But ere this Queen Anne had given birth, 'Sunday, the Eve of our Lady's Nativity, 7th September, 1533, about 3 p.m.,' to a daughter, who was baptized the Wednesday following, in the Friars' well-known church, by the name of Elisabeth, or - Ysabel'-so wrote Chapuys-her good grandmother's name. Cranmer had the honour of being golfather. The passage from the palace at Greenwich to the Franciscen church was hung with arras, and was strewn with rushes, for the gay baptismal company. The future queen-long since of glorious memory-was a disappointment in regard to sex-to Henry, Anne, the physicians, and a host of self-confident astrologers. But it was hoped and prayed that a jubilant Te Deum might yet erclong be chanted for the birth of a prince.

$$
\begin{aligned}
& \text { * B. vi., } 1491 \text {. } \\
& +2 . ; \text { Henry VIII., c. } 22 \text {. Sec B. vii., } 392 .
\end{aligned}
$$

$\$$ For acknowledgments of the royal supremacy by religious houses and corporations-in May, June, July, August, October and November, 1524 - 'submitting to IJenry VIII. and Queen Anne, and renouncing the Bishop of Rome's authority,' see B. vii., :221, 1121, 1216, 1347, 1594. 
The infant Elisabeth was little more than a year old when the complicated controversy, which had filled with negotiations and intrigues seven long years, was terminated and completed by the Act of the Royul Supremacy, passed in the beginning of November, 1534** By this Act all authority in matters ecclesiastical was vested solely in the crown. The king thenceforward was to be 'taken, accepted, and reputed the only supreme head on earth of the Church of England,' with all the 'honours, jurisdictions, authorities, immunities, profits, and commodities, to the said dignity belonging.' At the opening of 1535 Henry formally took the title of 'on earth supreme head of the Church of England;' and shortly afterwards Crumwell was raised to the post of the king's vicegerent in all matters ecclesiastical.

Thus at last, after a tedious and changeful conflict, England stood forth unbound, the fetters of her long submission to a foreign exacting yoke all broken from her free limbs, and cast a heap of shivers at her feet.

* 26 Henry VIII., c. 1. See B. vii., 1379.

It is noteworthy that Henry had already taken up, in his relation to the monasteries, the position previously filled by the Pontiff. Chapuys informed the Emperor (July, 1531): 'By the advice of the ChapterGeneral of the Cistercians, there has lately come hither the Abbot of Chalia (Chailly) to visit the houses of this Order, of which there is great need. But,' be added, 'the King would not allow him, saying that he was King and Emperor, and, if I remember rightly, Pope.'-B. v., 361. 


\section{BOOK V.}

MARTYR TESTIMONY.

\section{I.-ONE CONDITION TO SUCCESS WANTING.}

The sun of God's truth was risen upon England. The New Testament was before the eyes of the people in intelligible, homely English; its truths were quickening many hearts. This was the first and most momentous of all eonditions for a sound reformation of religion. Besides this, the links which for centuries had bound the Anglican Church to the papacy with more or less tenacity were all now finally severed, as has been shown. But there was yet another condition imperatively needed for the success of the reforming morement, which had hitherto for the most part been lacking. 'This was the courageous spirit of self-sacrifice. No system of religion can ever gain wide acceptance which is not recommended by that cogent argument of thorough whole-heartedness which is supplied by the readiness of its adroeates to relinquish even life itself, at the claims of what they believe to be the truth.

The absence of this martyr-spirit had been matter of taunt from opponents. 'There is not one of them,' upbraided Sir Thomas More, 'who dare abide by his faith unto the death.' In answer to this reproach, Tyndale could only name one martyr, 'Thomas Hitton,' whom he rlescribed as 'dieted and tormented seeretly, and murdered at Maidstone by the Bishops of Canterbury and Riochester (Warham and Fisher).'*

Yet, after all, the faltering in testimony of the early (iospellers, lowever unworthy of the cause, may admit of * Tyudale's Works, P.s., ii., p. 340. 
some extenuation. For some time the new promulgators of a more Scriptural creed were naturally enough far from being clear and well-grounded in their reasonable convictions. They may be compared to prisoners rescued on a sudden from a dark dungeon, and placed in the upper region of bright sunshine. Mazed and bewildered, it was only after a time, and by slow degrees, that their eyes could grow accustomed to the unexpected daylight.

To the general lack of heroic constancy there was always, however, one conspicuous exception-the translator of the New Testament. It may be well to use this opportunity of elucidating Tyndale's opinions on pressing questions of the time, and of tracing his reforming progress somewhat farther. Humble, but independent of prevalent notions, he was not the man to abjure, or in any way to belie, his deep-rooted religious principles. He was an exile; yet his publications, through their wide-spread influence among his countrymen, were for the most part as so many successive steps onwards in the Scriptural progress of his nation.

Tyndale's independence of thought is well illustrated by his peculiar views on the great divorce question, although here a strange weakness of judgment is at once exposed to censure. Unlike Latimer, and the immense majority of the English Protestants, he did not regard Henry's wedlock with Katharine as contrary to Scripture. As little did he adopt Luther's sensible and characteristic verdict, that 'separation after so many years of cohabitation would be an enormity greater than any marriage coulil have been.' He struck out quite a novel path of his own, and maintained in his 'Practice of Prelates' ${ }^{\prime}$ _ published towards the end of 15:30 - that marriage with certain near of kin is objectionable, not by virtue of 'the law natural graven in the heart,' but because by such marriages the duty of those in relative positions, similar to that of parent and child towards one another, becomes compromised. Not the law of nature, but the fifth commandment, in his judgment, interposed the hindrance. 'The sending out of daughters into another lin is the greatest cause,' he declared, 'of peace

* In this treatise occurs the celebrated allegory of the 'Ivy Tree,' to illustrate the rise of the papacy.-Tyndale's Works, P.S., ii., p. 27(, etc. 
and unity that is in the world.' He went so far as to assert that, 'if the King of England had a son by one wife, heir to England, and a daughter by another, heir to Wales, thenbecause of the great war that was ever wont to be between those two countries-I would not fear to marry them together.'* T'hus 'Tyndale, on one hand, flatly condemned the divorce, so that it is not surprising that, when Henry requested that the exiled translator should be delivered into his hands, the emperor unhesitatingly refused to comply.t Ard, on the other hand, Tyndale evidently would have been willing, for such an object as the safe establishment of the succession, even to sanction the matrimonial union of Harry Fitzroy with the Princess Mary.

At the same time, Tyndale was ready to accord the king the right of private judgment in the interpretation of Scripture to a most dangerous extent. 'If the law of God suffer it, then,' he suggested, 'let his grace put forth a little treatise in print, and even in the English tongue, that all men may see it, for his excuse and the defence of his deed, and say, "Lo, by the authority of God's Word do I this;" and then let not his grace be afraid either of the emperor, or of his lords, or of his commons and subjects; for Gud hath promised to keep them that keep His laws.' The value of the innate instincts of human nature, and the universal handwriting by God's finger on the heart of man, Tyndale underrated. It was partly a reaction from the long and very prejudicial neglect of the inspired Scriptures, that he thus raised their authority to a solitary pre-eminence, which almost obliterated every other moral landmark. But while censuring his faulty judgment, it is impossible to fail to admire his consisteney with his own principles, and his unswerving confidence in the livine promises. 'God's Word,' he declared, 'is the chiefest of the apostles, and pope, and ('hrist's vicar, and head of the ('hurch, and head of the gencral council.'

The 'Practice of Prelates' pursued the subject of which it treated continuously down, as he said, to 'the practice of our

* Tyndale's Works, P.S., ii., pp. :32:3-33:3.

+ Subsequently, however, when a book by Peto against the king's new marriage was sent to Tyndale at Antwerp for correction, the translator declined to 'meddle any more in his prince's matter.'-B. vi., 1324. 
time,' and in England itself. But an exile from his country, in an age when locomotion was slow, and international intercourse generally impeded, when as yet the mysteries of steam and electricity were undreamed of, before the birth, even, of the earliest newspaper, his information was very inadequate; and, in dearth of accurate intelligence, the translator drew upon the resources of his own suspicions. The modern reader is amused to find that Tyndale regarded the downfall of Wolsey as altogether a 'feigned procedure,' a 'feint,' an exercising of the cardinal's 'angel wit,' a 'cast of his old practice,' a 'tiding over of what he had learned of his necromancy' would be a 'jeopardous year,' a 'putting down of himself under a colour.' Erasmus quoted Wolsey's worls to the effect that More was 'the only person fitted to succeed him, although he (Wolsey) was not partial to More.' But Tyndale imagined that Wolsey and Nore were in secret at one; and that it was by the cardinal's own contrivance that 'the chiefest of all his secretaries (More) had been set up in his roorn, - - one 'nothing inferior to his master in lying, feigning, and bearing two faces in one hood, a whelp that goeth not out of kind from his sire, the chiefest tastle (lure)* wherewith the cardinal caught the king's grace.'

'Tyndale had heard of the 'Articles' against 'this caitiff' Caiaphas,' as, according to the custom of the 'brethren,' he terms Wolsey, and of the impeachment; and conceived the whole business to be merely a wily pretence. 'To blind the world withal many quarrels were picked; the cardinal might not speak with the king's grace; the broad seal was fetched away; high treason was laid to his charge; first, that he had breathed (heard I say) in the king's face when he had the ** O hypocrites! but the very treason that he had wrought was not spoken of at all, nor ought worthy of a traitor done to him at all.' $\dagger$ The Reformer's writings, as might be expected from his lengthened exile, disclose less acquaintance with English than with German and imperial affairs. Sharing the bitter antipathy to the cardinal common

* Tassel or tiercel (because a tierce, or third part, less than the female) was the male of the goshawk. Grocers then sold hawks.- 'Paston Letters.'

† Tyndale's Works, P.S., ii., p. 335. See also B. v., 1094 (2). 
to the 'brethren,' he little realized what is nevertheless strictly true, that the ambitious, imperious Wolsey was even lenient as a persecutor in comparison with the conscientious, Platonic More.

Tyndale must have quitted Marburg after the publication there in December, 1530, of the 'Practice of Prelates.' Lambert had fallen a victim to the sweating sickness; the tone of morals was low, and continued to be sensibly on the decline; and thenceforward Antwerp was for the most part the translator's place of residence. His movements in the previous year are involved in some perplexity. In August it seems that he was in Antwerp; for there it was that the famous bargain for the purchase of New Testaments was arranged by a confidential agent for Tunstal, who, in conjunction with llore, had just concluded the Treaty of Cambray.

Of this bargain Foxe writes: "The bishop, thinking he had God by the toe, when indeed he had, as after he thought, the devil by the fist, said to Packington, his commercial agent, "Cientle Mr. Packington, do your diligence, and get them (the Testaments), and with all my heart I will pay for them whatsoever they cost you ; for the books are erroneous and nought, and I intend surely to destroy them all, and burn them at Paul's Cross." Augustine Packington came to William Tyndale and said, "William, I know thou art a poor man, and hast a heap of New Testaments and books by thee, for the which thou hast both endangered thy friends and beggrared thyself; and I have now gotten thee a merchant which, with ready money, shall despatch thee of all that thou hast, if you think it so profitable for yourself." " Who is the merchant?" said Tyndale. "The Bishop of London," said l'ackington. "( )h, that is because he will burn them," said Tyndale. "Yea, marry," quoth Packington. "I am the gladder," said Tyndale, "for these two benefits shall come thereof: I shall get money to bring myself out of debt, and the whole world will ery ont against the burning of God's IVord; and the overplus of the money that shall remain to me* shall make

* 'Eleven coarsely-cut illustrations of the Tabernacle and its furniture had appeared in the Dutch Bible printed by Vorstermann at Ant- 
me more studious to correct the said New Testament, and so newly to imprint the same once again, and I trust the second will much better like you than ever did the first." And so forward went the bargain; the bishop had the books, Packington had the thanks, and Tyndale had the money.' Demaus supposes* that the volumes sold to Tunstal consisted chiefly of "copies of the various surreptitious editions which had already appeared at Antwerp.' 'These George Joye described as so disfigured by the blunders of ignorant Dutch printers that 'the simple reader might ofttimes be tarried and stick.' But is it at all likely that these 'surreptitious copies' should have been amongst Tyndale's 'heap of New Testaments'?

In September the translator had probably returned to Marburg, where a month later he may have rejoiced in the opportunity of communicating to Luther the progress in translation which he had made and was making. Fryth must have remained at Marburg; at least, he issued thence, from Hans Luft's printing-press (July 12, 1529), his 'Revelation of Antichrist,' a translation from Luther. 'Tyudale, having published his 'Practice of Prelates,' concentrated his attention on the Pentateuch, and then superintended the printing of the several books. It is noteworthy that, having his IS. translation open before him, he quoted from his versions of Exodus and Deuteronomy in his 'Practice of Prelates' as though they were already in print.

Genesis was completed from the press of Hans Luft January 17, 1530, as appears by its colophon. That 15:30

werp in 1528 , and appeared again, 'every line and blot' the same, says Demaus, in Tyndale's version of Exodus. Four year's later the Dutch Bible was repinted by Vorstermann, but the old illustrations were superseded by new ones. The old illustrations had probably been purchased by 'Tyndale with some of 'the overplus of the money,' and taken to Marburg.

Foxe's narrative of Tyndale's shipwreck upon the coast of Holland, in voyaging to Hamburg, and loss of his 'books, writiugs, and copres,' whereby he was compelled to begin the Pentateuch again-in which work he used, according to Foxe, the help of Coverdale-besides inaccuracies of date, is unsupported by other documents ; yet it must not be bastily rejected. Foxe and Coverdale were contemporary clergymen in London for nearly ten years in Elizabeth's reign; and from Coverdale, no doubt the information came. 
was the year of publication-and not 1531, as Westcott was inclined to think - seems to be rendered certain by the authoritative denuneiation, May, 15:30, of the Old Testament translation.* The remaining books followed at short intervals. Each book has a separate prologue, and the whole tive books have a preface. There are also marginal glosses, luther-like in boldness. Probably all the five books were printed at Marburg, $\uparrow$ although Genesis alone bears the printer's name, as well as the date. The I'entateuch was reissued in 15:34 with a few alterations.

The only other version of a portion of the Old Testament which Tyndale is known to have published-exeept the brief fragments of the 'Epistles from the Old Testament according to the Use of Salisbury,' which are appended to his Testament of 1534 and that of 1535 -is the prophet Jonah, with its eharacteristic prologue. There was no little attraction for our Reformers in this book of Scripture. Nineveh, to their eyes, was an old-world representation of modern London. 'Is there not reigning in London,' declaimed Latimer, 'as much pride, as much covetousness, as much cruelty, as much oppression, and as much superstition, as was in Nebo? Yes, I think, and much more, too." the moral and spiritual resemblance of the two eities, there was also the portrait of Jonah himself, only too elose a likeness, if not to 'Tyndale, yet to the large majority of the 'brethren' of his time. 'Jonah,' wrote Tyndale, although 'chosen of (iod to testify his name unto the world,' was 'but yet a young scholar, weak and rude, after the fashion of the Apostles while Christ was yet with them bodily. We, he added, 'are but children and young seholars, weak and feeble, and must have leisure to grow in the spirit, in knowledge, love, and in the deeds thereof, as young ehildren must have time to grow in their bodies.' After this publication

* B. iv., part iii., 6401, 6402 ; Westcott's 'English Bible,' 1. 45.

+ 'The ornamental title-pages - the same throughont-are unquestionably Hans Luft's ; and what is tecbnically called the "forme" is the same.'-Demaus.

Genesis and Numbers are printed in the customary black letter, the rest in Roman letter.

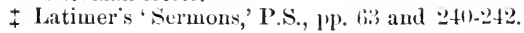


Tyndale still toiled on at his Old Testament translation, keeping faithfully to the Hebrew, and comparatively disregarding the Vulgate. At the date of his martyrdom (October 6,1536 ) he had proceeded with his version as far as the end of the Second Book of Chronicles.

The prologue to . Jonah remained extant, the tcxt had been long missing; so long, that-although enumerated amongst the 'heretical books' denounced at Paul's Cross, Advent Sunday, 1531 -it had come to be questioned whether an English version of the prophet had ever been published. But in 1861, Lord Arthur Hervey, now Bishop of Bath and Wells, then Archdeacon of Sudbury, discovered at Ickworth Rectory, bound up with an old volume which had been in the family possession for more than two centuries, a copy of the text of Jonah. Version and prologue appeared together without date, place or printer's name. But, as in the Pentateuch, the author and translator was clearly revealed by the brief address and initials, 'W. T. unt,o the Christian reader.' The work was reproduced in 1863 in facsimile by Francis Fry.* There can be little doubt that it was first published in 1531, at Antwerp, soon after Tyndale's removal thither.

The Treaty of Universal Peace was made an instrument by Tunstal and More for putting a $\operatorname{clog}$ on the circulation of the Scriptures and Scriptural doctrine. A prohibition was inserted against printing or selling Iutheran books, whether in England or the Low Countries.

The two ladies, who had successfully accomplished the Cambray Treaty, did not long survive their sisterly labours. Margaret deceased December 1, 1530, and Louise outlived her less than a year. The government of the Low Countries was next entrusted to the Dowager (Queen of Hungary, a sister of Charles, a woman of masculine character and autocratic temper. Margaret, a wise administrator, had borne some share, in conjunction with another Margaret, the energetic widow of Charles the Bold of Burgundy, and sister of Edward IV. of England, in moulding the youthful character of her nephew, and to him she bequeathed her wealth, a rental

* 'The Prophete Jonas, etc., with an Introduction by Francis Fry, F.S.A.' 'The type,' Fry observes, 'is the same as that used by Martin Lempereur in the Bible in French, Antwerp, 1530, folio.' 
computed at 100,000 crowns a year, besides jewels and ready money.* Her dying commsel was inwoven in the bequest that the emperor should hy all means strive to maintain the blessing of peaceful relations with France and England. The 'Ladies' Peace,' however beneficial to Europe in other respects, cannot be regarded as favourable to the progress of the Reformation.

The publication by Tyndale of his version of the Pentateuch drew out into hostility, strongly pronounced, the full force of Romish intolerance. A great meeting by royal appointment was held May, 15:30, when the ehief prelates, the most learned men from the universities, "twelve from either,' and nominees chosen by the crown, debated for twelve days the burning question of religious publications. According to 'Tyndale, More was, upon this occasion, 'the special orator of the bishops, to feign lies for their purpose.' A solemn meeting in St. Edward's Chamber, Westminster, in presence of the king, closed the consultations. It was resolved that Tyndale's translation was 'corrupted as well in the Old Testament as in the New, and that his treatises were fraught with 'great errors and pestilent heresies.' A declaration to this effect was to be published by preachers in their sermons. It is, however, a significant token of progress that in the ensuing proclamation (June 22, 15:30) the king, whilst maintaining that his paternal care did not bind him to give the Scriptures to his peoples in their own languages, yet added that he would have the New Testament 'faithfully and purely' translated; and if the people are meek and submissive, and he believes it will eonduee to their good, he will give the translation to them. $\dagger$

All persons were cautioner -in terms similar to those of a proclamation issued the precerling Deeember-against buying or receiving heretical books, whether in English, French or Dutch. Those in possession of such books were to surrender them, within a fixed time, to the bishop or curate or parish priest; and such as were unwilling to do this were to be made by their punishment a terrible example to others. Another bonfire of versions of Scripture and religious tracts blazed at Paul's C'ross.

* Ven., iv., (it);.

† B. iv., part iii., 6401, 6402, 6487. 


\section{II.-HUGH LATIMER.}

These denunciations of the king and lierarchy were answered by a fresh importation of proscribed books. And now from the heart of England itself arose the living voice of protest in support of Tyndale's pen. Hugh Latimer had already earned the reputation of a great preacher. His pulpit warfare with Fellows of St. John's, Cambridge, 'Bayn, Bryganden, Grenewod, and Proctor of the blak frears,'* had served to swell the volume of accusations rife against him. But the royal disposition towards him continued to be favourable, under the belief that the angry imputations of heresy by his opponents were very much due to his vigorous advocacy of the king's side in the divorce question. He had been one of the Cambridge delegates at the deliberations of the May meeting. His controversy with Buckenham, prior of the Dominicans, may be interesting as a quaint illustration of the peculiar character of the sermons of that age, when jests and personalities were not excluded from the pulpit as inadmissible even by the most distinguished preachers. Buckenham objected against the reading of the Scriptures in the vulgar tongue, that the people might put a too literal construction on what they read. Thus the ploughman might cease from his ploughing, and where, then, the sowing and the harvest? The baker might be sparing of leaven, and the national health be endangered. The incontinent might even pluck out his eyes, and the realm become full of blind men. Such strange reasoning Latimer exposed with humorous drollery. It was a mistake, he said, to imagine that the common people

* B. iv., part iii., 6176. See also memoir prefixed to Latimer's 'Sermons,' P.S., p. iv. 
failed to apprehend metaphor. The contrary was the case. When, for instance, they beheld a fox painted preaching out of a friar's cowl, they at onee eaught the intended meaning, "what hypoerisy, eraft, and dissimulation lie hid many times in these friars' cowls, willing us thereby to beware of them.' The object of laughter and contempt, the Dominiean was glad to slink away. Latimer was introduced at court by Dr. Butts, Henry's second physician, a cousistent friend to the Reformation. He preached before the king during the Lent of 1530 and at other times with much acceptance, the king himself especially being loud in his praise.*

This distinguished preacher now came forward at this juncture with singular intrepidity, and addressed to his sovereign a letter of outspoken boldness, in advocacy of permitting the people to read the Word of God in their native tongue. The whole letter, admirable as it is, would be too long for insertion; its close has the following words: 'As concerning your last proclamation, prohibiting such books, the very true cause of it, and chief counsellors were they, whose evil living and eloaked hypocrisy these books uttered and disclosed. And, howbeit that there were three or four that would have had the Scripture to go forth in Euglish, yet it happened then, as it is evermore seen, that the most part overeometh the better. . . . And take heed whose counsels your grace doth take in this matter, that you may do that God commandeth, and not that seemeth good in your own sight, without the Word of God; that your grace may be found acceptable in His sight, and one of the members of His Church, and according to the office that He hath called your grace unto, you may be found a faithful minister of His gifts; and not a defender of His faith: for $\mathrm{He}$ will not have it defended by man, or man's power, but by His Word only, by

* ' Warch-21 Henry V'III. Rewards to a black monk, Mr. Latamer, and the Vicar of Croydon, for preaching before the king the first three Sundays in Lent, 20s. each.'

'March, 1531). To Master Latymer, who preached before the king the seeond suuday in Lent, $\mathrm{L}:$ '.

'September, 1530, to Mr. Foxe. for money laid ont to Mr. Latymer, and other scholars of Cambridge, for their costs to Iondon and back, As.' -Privy Purse Expenses, B. v., pp. 317, 749, 751. 
the which He hath evermore defended it, and that by a way far above man's power or reason, as all the storics of the Bible make mention. Wherefore, gracious king, remember yourself; have pity upon your soul, and think that the day is even at hand when you shall give account of your office, and of the blood that hath been shed with your sword! In the which day that your grace may stand stedfastly, and not be ashamed, but be clear and ready in your reckoning, and to have, as they say, your quietus est sealed with the blood of our Saviour Christ, which alone serveth at that day, is my daily prayer to Him who suffered death for our sins, which also prayeth to His Father for grace for us continually, to whom be all honour and praise for ever. Amen. The Spirit of God preserve your grace! Anno Domini, 1530, 1 Die Decembris.'

Real respect for a good man was one of the better traits of Henry's nature. He was not offended by this faithful appeal, which Froude has described as 'of almost unexampled grandeur.' Instead of taking umbrage, he shortly afterwards appointed Latimer a royal chaplain; and inasmuch as the great preacher's health was infirm-for he was troubled with 'pleurisy, colic, and stone,' and much needed the careful nursing of his trusty housekeeper, 'good Mistress Patcham'he conferred upon him, at the solicitation of Butts and Crumwell, early in 1531, the benefice of West Kington, near Chippenham. Thus removed from the turmoil of Cambridge strife and controversy, 'the poor parson of poor Kington,' as Latimer would style himself, laboured with a vigilance worthy of the primitive age. His rural sphere-'my little bishopric of West Kington,' as he called it-was dear to him. His vicarage has for many years ceased to exist. Its site is said to have been only a few yards withdrawn from the brook, which, between two sides of a ravine, with cottages of the peasantry interspersed, now pleasantly glides, now dashes in a torrent-a not altogether inapt emblem of the reformer's preaching. The ancient church remains conspicuous on one of the hillsides. A yew-tree, associated by tradition with the reformer, its trunk enclosed by a circlet of stone, still adorns the churchyard. Under its venerable boughs Latimer would sometimes take his stand, and instruct and charm a congre- 
gation gathered from near and distant parts of the neighbourhood, too numerous to be contained within the church walls.

In that age preaching was an engine frequently used for political as well as spiritual purposes-very effective when handled by such a master of the art as Latimer. His collected sermons, delivered on various occasions, and before very different audiences-at Cambridge and Paul's Cross, before the king and his court, to ploughmen and artisans-are not the lcast interesting of the valuable publications of the Parker' Society. Despite occasional 'huzzing and buzzing,' he was able to detain the listeners, often considerably beyond the hour, fast riveted in the chains of profound attention. Although he had been a painstaking student, it was not as a scholar or subtle theologian, but as a plain, practical Christian, that he mingled humour and pathos in his efforts to instruct and improve. Expositions of Scripture, solutions of doctrinal doubts, but oftener still humble, commonplace duties in contrast to 'ecclesiastical will-works,' obedience rather than sacrifice, racy illustrations from nature or art of the topics handled, homely proverbs, personal reminiscences, spiritual experiences, anecdotes enforcing some moral lesson with a spice of wit, instructive allegories, noted examples from sacred or profane history, unvarnished denunciations of tricks of manufacture and trade, direct appeals to the conscience, forms and materials, thus diverse like many-coloured threads, were all wrought into a texture essentially harmonious by the preacher's singleness of aim and fervour. His pulpit eloquence exemplified his belief in his own maxim, that 'preaching is the footstep of the ladder of heaven.' There has been no such preacher in England, pronounced D'Aubigné, as honest Hugh Latimer.

Yet even he was at this period but a 'young scholar in grace'-Jonah-like in weakness. Cited to appear 'at St. Paul's Monday, Ianuary 29, 1532,' before Stokesley-of whom he wrote, 'It is a rare thing for a preacher to have favour at his hand which is no preacher himself, and yet ought to be'-and afterwards cross-questioned by Warham, his examinations seemed interminable. Summoned before Convocation, March 11,1532 , he was at length induced to affix his signature (April $10,1532)$ to sixteen articles, the fifteenth whereof was that 
'images are profitable,' and the sixteenth that it is profitable for them to be 'decked and trimmed, and candles set before them.' To such deeply papistical dogmas was even Latimer persuaded to profess assent-dogmas which he had impugned before, and which he shortly afterwards impugned again.

To this period belongs a scene which he has himself painted vividly in one of his sermons-too characteristic to be omitted: 'Once I was in examination before five for six bishops, where I had much turmoiling. .... At the last I was brought forth to be examined, into a chamber hanged with arras, where I was before wont to be examined; but now at this time the chamber was somewhat altered; for as before, there was wont ever to be a fire in the chimney, now the fire was taken away, and an arras-hanging hanged over the chimney, and the table stood near the chimney's end; so that I stood between the table and the chimney's end.' He went on to recount how a bishop, with whom he had been very familiar, an aged man, put to him a "very subtle question. "I pray you, Master Latimer," said he, "speak out; I am very thick of hearing, and here be many that sit far off." I marvelled at this, that I was bidden speak out, and began to misdeem, and gave an ear to the chimney. And there I heard a pen walking in the chimney behind the cloth. They had appointed one there to write all my answers. . . . . God, which alway hath given me answer, helped me, or else I could never have escaped it, and delivered me from their hands.'

Another celebrated preacher, Dr. Edward Crome, 'parson of St. Anthonyn's,' sometimes invited to preach before the king, had shown as little fortitude in the hour of trial, and had abjured.* His printed 'Confession' was criticized by the Protestants as not only 'a very foolish thing, but a lie.' Thus the years 1531 and 1532, like 1528, were marked by relentless persecution on the one side and pusillanimous weakness on the other. The prelates had purchased at a heavy price the royal complicity, and were little inclined to let the opportunity pass unused. Even the dead were not allowed to repose in peace; for the bones of William Tracy of Toddington were exhumed in obedience to a decree of

* B. v., 129, and pp. 318 and 928. 
Convocation.* Tyndale's brother .John was fined, and he and another London merchant with him, named Patmore, were paraded on horseback, their faces turned to the horses' tails, their cloaks hung round with leaves of the New Testament, and made a ridiculous spectacle to the people, for the crime of assisting in the circulation of the prohibited book. Bayfield, 'a monk of Bury,' 'Tewkesbury, Bainham, and others perished at the stake as 'relapsed heretics.' Humiliating to the Protestants, to a lamentable degree, was the prevailing terror of death and suffering. It is the patient spirit of heroic consistency, when their doctrinal system had been more maturely reasoned out, and their convictions had become rooted, which, under the sharp trials of the Marian persecution, has branded detestation of Rome, in letters of fire, deep in the staple of the English character.

After his own timid recantation, Latimer was conducted, towards the end of April, to visit James Bainham. a 'learned lawyer,' in his trouble for conscience' sake, who had sometimes hung on Crome's lips in St. Antholin's Church, and sometimes had listened with unflagging attention to Latimer's pulpit exhortations. Bainham was awaiting death in the deep dungeon of Newgate. At a moment so solemn, Latimer instilled into Bainham's ear no inspiriting counsel-such as that which in his last and noblest hour he addressed to Ridley, to 'play the man,' but a cautious warning, 'not to jeopard his life for a doubtful matter.' In regard to 'satisfactory Masses, his conscience might be so stayed,' said Latimer, 'that he should rather die than recant:' but he admonished him against 'vainglory,' with which the devil would be ready to tempt him "when he came into the multitude of the people. $\dagger$ The words sound like a feeble attempt at an apology for his own recent sad defection. Thus even Latimer, eventually stout and dauntless, quite broke down at this distressing period of captious half-hcartedness. And his prudent casuistry marks but too correctly the craven spirit prevalent among the 'brethren.'

$$
\text { * B. v., } 928 \text { † B. v., } 583 ; \text { Appendix, } 29,30 \text {. }
$$


III.-AN EFFORT TO REPAIR FAILURE.

Is the midst of depressing symptoms of faithless inconstancy, the nobler spirit of self-sacrifice for Christ was already beginning to exert its power against the calculations of expediency. Bilney, with all his self-denying earnestness, had set a cowardly example, which had found too close and frequent imitation. After bearing his fagot he had been kept a year in prison, and then had returned in 1529 to Cambridge. But, degraded in his own eyes, he had now become quite unlike his former self. Dejected and forlorn, his habitual earnestness was gone; grief, misery, shame weighed down his spirits. The thought that he had been guilty of the unpardonable sin was torture to him. At last his self-reproach became so deep and intense that he was resolved to bear the stings of his conscience no longer. Bidding farewell, therefore, to his most intimate friends, one evening at 'ten of the clock,' he put his resolution into effect, and started to 'go up,' as he said, ' to Jerusalem.' He took with him copies of the New Testament and of the 'Obedience.' Now that his determination was formed, and in part put in execution, to sacrifice his life for his Master, his old peace returned, and with it his old zeal. He passed through Norfolk, Suffolk and Essex, the ground he had been wont to traverse formerly, preaching and teaching with persevering intrepidity. He entered Kent, and distributed Testaments even at Greenwich. He then retraced his steps, confirming the 'brethren,' teaching from house to house, preaching in fields and open places, and so worked his way back to Norwich. Here he visited a noted convert, " the lady ankeres 
of the Black Friars,' and gave her a copy of Tyndale's Testament and of the 'Obedience.'

But at this point his progress was interrupted. Blind Bishop Nixe was on the watch by his emissaries for the renegade returned to his old zeal and labours, and promptly had him arrested. The culprit arrested, Nixe forthwith sent up to Sir Thomas More for a writ to burn him. 'Burn him first,' retorted More, 'then afterwards come to me for a writ at my hand.' Placed before the judge, in the presence of Thomas Reed, the Mayor of Norwich, Bilney made an appeal to the king, pleading the new title just conferred on Henry by Convocation and Parliament. Voices were heard in the court, 'Mr. Mayor, you are bound to take him away.' But, notwithstanding signs of popular displeasure against his persecutors, he was condemned and delivered over to the sheriffs, and lodged in the Guildhall. One of the sheriffs, according to Foxe, was Thomas Necton, brother of Robert Necton, the tract-distributor, who craved pardon for acting under compulsion the office of his gaoler.

A prisoner in the Guildhall, Bilney composed a portion of two homilies, neither of which did he finish. The incomplete manuscripts he gave to Pellis, an agent of the bishop, from whom the mayor took them into his own safe-keeping. He forwarded also a copy to the Duke of Norfolk. In the chapel of the Guildhall a revocation of certain heretical opinions was presented to him by Pellis. But the statements seem to be very much confused, both in reference to Bilney's behaviour in prison and also afterwards at the stake. His mind was in a state of much nervous excitement, and-at least, on minor points of doctrine-his convictions were far from being settled and clear. The account of Bilney by Latimer, who was very intimate with him, declares the simple truth: 'I am told,' wrote Latimer, ' that the bishop ('Tunstal) has informed the king that $I$ defend Bilney and his cause against his ordinaries and judges. I did nothing of the kind, unless it were in admonishing judges to act indifferently. I have known Bilney a long time, much better than did my Lord of London, for I have been his ghostly father many a time. I ever found him meek and charitable, and a simple, good 
soul, not fit for this world. But if he has done anything contrary to Christian obedience I do not approve it. How he ordered or misordered himself in judgment I cannot tell ; but I must wonder if a man living so charitably and patiently should die an evil death.'**

In the outskirts of the city of Norwich is the well-known St. Leonard's Hill, which, for the most part, looks desolate and lonely. But on Saturday, August 19 (St. Magnus's Day), 1531 , its slopes were covered with a large crowd of people drawn from the city and its vicinity. A cave in the hillside still bears the name of the Lollards' Pit. Hither Bilney was led, through the Bishop's Gate, attended by his friend Dr. Warner, the parson of Winterton, celebrated for his lectures at Cambridge, which had been shaped after the pattern of Colet's at Oxford. Bilney was composed, and even cheerful. Resolved to 'sustain a pain for the time, whereon notwithstanding followeth joy unspeakable,' he answered to the condolence of friends, ' my ship will now shortly be in the haven.' The night before, in preparation for the final ordeal, he had 'tasted the fire,' putting his tinger in the flame of the candle, and holding it there without flinching until it was burnt to the bone.' +

There was a young man, of Benet (Corpus Christi) College, Cambridge, present among the spectators who could never obliterate from his memory and heart that morning's scene and its lessons. This was Mathew Parker, subsequently illustrious, destined from being chaplain to Anne to be promoted, under her daughter, to the metropolitan see of Canterbury, and in that exalted post to crown and establish our national right to the possession of God's Word in our native tongue, and to the public enjoyment of faith in its truths, for claiming

* Latimer to Sir Edward Baynton.-B. v., 607.

At the close Latimer writes, ' 1 intend to make merry with my parishioners this Christmas, for all the sorrow, lest perchauce I never return to them.'

See also B. v., 37:3, 373, 928, and 'Acts and Monuments' folio, ii., pp. $258-279$.

$\dagger$ Bilney's Latin Bible, preserved in Corpus Christi College, Cam bridge, is said to have, amongst other passages, the following: " When thou walkest through the fire thou shalt not be burned, neither shall the flame kindle upon thee' (Isa. xliii. 2), marked with a pen in the margin. 
which Bilney was now to suffer death. There can be no doubt that Foxe's account is principally derived from Parker himself, and thus transmits the impressions of an eyewitness.

Bilney had been degraded from the priesthood, and now appeared 'in a layman's gown, the sleeves hanging down, and his arms out, his hair piteously mangled.' 'A little, singular person,' he was, says Foxe, 'but always of a good, upright countenance.' Before he was led to the stakc, he made what the mayor' called 'a good and upright exhortation to the people.' He declared that he died in the faith of Christ. He exonerated the four orders of friars, at their special request, from the imputation of being guilty of his death, and even exhorted the bystanders to contribute their alms to them. He rehearsed the Creed, bowing with low reverence at the name of Jesus. On coming to the article, 'I believe in the Apostolic Church,' he made a pause, and expressed solemnly his deep contrition that, having sworn not to preach without license from his ordinary, he had broken his oath. He lamented expressly also disrespectful words which he had suffered to escape him; as, for instance, that the pope's curse only cursed men openly, and was of no validity before God. On the contrary, the sentence of the Church, he said, must be feared and obeyed. He believed in the Catholic Church. Chastity he held to be meritorious, but he would leave, he said, the question of the marriage of priests to the disputation of the doctors. Far from disapproving of fasting, he wished that the prelates would use more of it.

Pellis placed in his hand a bill-the revocation which was required from him-and desired him to read it. Bilney read it softly to himself-so softly that Reed, the mayor, "though very near, could not hear him.' He then freely and plainly declared his mind to the people; but what he said 'differed from the bill.'*

When he had thus finally unburdened his conscience he made ready for death. His gown was put off, and he walked calmly to the stake. $\Lambda$ little ledge had been so placed that he

$$
\text { * B. v., 52:, } 560,569 \text {. }
$$


might stand on it, to be better seen, on account of his small stature. Here he knelt, and prayed fervently in secret. After earnest prayer he repeated aloud Psalm cxliii., repeating thrice with emphasis the second verse: 'Enter not into judgment with Thy servant; for in Thy sight shall no man living be justified.' His jacket and doublet were now put off, and he stood simply in his hose and shirt upon the ledge. A chain was drawn round his body and fastened to the stake. To Warner he bade farewell by saying: ' Master doctor, feed thy flock, that when the Lord cometh He may find thee so doing.' Fire was then set to the reeds and fagots. At first the fire rose high and strong; but then, the weather being stormy, a violent gust of wind blew the flames away from the martyr's person, who continued raising his hands and ejaculating, 'Credo !' and 'Jesus !' But after a short time the fire obtained a firmer hold upon the wood and encircled the body, which was soon observed by those standing around to be 'withered' and bowed downwards upon the chain. An officer struck out the staple with his halberd, and Bilney's corpse fell into the flames.

Many of the bystanders 'smote their breasts' as, musing over what they had just witnessed, they turned their steps homewards. The proceedings afterwards formed the subject of much discussion, and an examination took place before the lord chancellor, the mayor and some of the aldermen being called upon to give evidence in reference to what had occurred both at the trial and at the execution. Inquiries on these topics were also instituted in the House of Commons, and remarks were let drop which betokened general dissatisfaction and displeasure. Old blind Nixe, who had pronounced the sentence of condemnation before the king's placet arrived, was not permitted to escape scot-free, notwithstanding Sir Thomas More's dismal joke, but was made to pay a heavy fine into the royal exchequer for his pardon.*

* Chapuys wrote to Charles, February 11, 1534: 'Four days ago the Bishop of Norwich, who is nearly ninety years old and blind, was condemned by a lay judge to the confiscation of all his property; his body to be at the king's mercy. His fault is having burnt as a heretic two years ago a doctor who was a companion and sworn brother of the Archbishop of Canterbury,' etc.-B. vii., 171 . 
The martyrdom of Bilney was not without bearing some good fruit. His character revealed itself in its weakness and its strength in the final ordeal. Deep penitence, conscientious truthfulness, devout constaney, shone clearly through the last acts and words of one who 'out of weakness was made strong.' With these better traits still mingled much dimness of perception on points of doctrine. On the whole, Tyndale's judgment was but too eorrect: "The death of them that come again after they have once denied, though it be accepted with God and all that believe, yet is not glorious.' But Bilney's effort to repair failure was the beginning of increased firmness and steadfastness of testimony. Soon a mind stronger and clearer was to yield a witness unflinehing in stanchness, from amid the shroud of flames, to a better understood and more Scriptural creed.

Nixe was also condemned in a præmunire for infringing the customs of Thetford, and for this offence was set free only by paying 30.000 crowns to the king. - B. vii., $48(2), 49,158,296$. 25 Henty VIII., c. 29. 
IV.-THE SEAL OF SUCCESS.

Is the troubled sky of the early English Reformation Tyndale and Fryth shone with a lustre less fitful that Bilney or Latimer. Thus the work of extirpating heresy, on which Henry and the prelates had entered conjointly with redoubled earnestness, would, it was felt, be very incomplete unless Tyndale and his son in the faith could be decoyed back to their native land and their energies restrained. Crumwell therefore commissioned his agent Vaughan to accomplish the delicate task of recalling home, by bland persuasions, the translator of the English New Testament. That Henry really intended to take Tyndale's life, if he could get him into his power, it would be too much to assert; but the result of obtaining possession of the 'arch-heretic's person,' whose whereabouts More described as 'nowhere and everywhere,' must only too probably have ended in his case too, as actually came to pass in the case of his henchman Fryth. Personally, Crumwell was by no means ill-disposed towards the Christian brotherhood, and his agent Vaughan was termed a 'Lutheran' by the imperial ambassador. But then, after all, Henry's great minister was only the wary instrument of his royal master's determined will. The epistles which passed between Vaughan and Tyndale, and their interviews in the early months of 1531 , throw much light upon the translator's character and his mode of life.

In his first letter to the king, dated January 26, 1531, from Barrow (Bergen-op-Zoom), Vaughan says: 'I have written three sundry letters unto William Tyndall, and the same sent, for the more surety, to three sundry places-to Frankforde, Hamborough (Hamburg), and Marleborughe (Marburg)-not knowing in which of these he might be.' Then, after expressing 
his fear that 'the bruit of what had lately ehaneed in England' might prevent the translator's return, Vaughan proceeds to mention a letter which he had received from Tyndale, 'written with his own hand,' and also another letter from him which he had in his possession, in answer to some other person; both which, at least for the present, are lost.

A little later a personal interview suceeeded to correspondence. 'The day before the date hereof' (April 18, 1531), 'I spake with Tyndall without the gates of Antwerp, in a field lying nigh unto the same. At our meeting, "Do you not know me?" said this Tyndall. "I do not well remember you," said I to him. "My naine," said he, "is Tyndall" "But, Tyndall," said 1, "fortunate be our meeting !" 'Then Tyndall, "Sir," said he, "I am informed that the king's grace taketh great displeasure with me for putting forth of certain books which I lately made in these parts, but specially for the book named 'The Practice of Prelates;' whereof I have no little marvel, considering that in it I did warn his grace of the subtle demeanour of the elergy of his realm towards his person, and of the shameful abusions by them practised, not a little threatening the displeasure of his grace and weal of his realm; in which doing I showed and declared the heart of a true subject which sought the safeguard of his royal person and weal of his Commons, to the intent that his grace, thereof warned, might in due time prepare his remedies against their subtle dreams. If for my pains therein taken, if for my poverty, if for mine exile out of my native country and bitter absence from my friends: if for my hunger, my thirst, my cold, the great danger wherewith I am everywhere compassed; and, finally, if for innumerable other and sharp fightings which I endure, not yet feeling of their asperity by reason I hoped by my labours to do honour to God, true service to my prince, and pleasure to his Commons-how is it that his grace, this considering, may either by himself think that in this doing I should not show a pure mind, a true and incorrupt zeal, and affection to his grace? . . . Again, may his grace, being a Christian prinee, be so unkind to God, which hath commanded His Word to be spread throughout the world, to give more faith to wicked persuasions of men, which, presuming above 
God's wisdom, and contrary to that which Christ expressly commandeth in His Testament, dare say that it is not lawful for the people to have the same in a tongue that they understand, because the purity thereof should open men's eyes to see their wickedness? Is there more danger in the king's subjects than in the subjects of all other princes, who have the same in their tongues under privilege of their sovereigns? As I now am, my death were more pleasant to me than life, considering man's nature to be such as to bear no truth."

Vaughan's persuasions, however, still proved ineffectual. Shortly afterwards Crumwell directed his agent to 'desist, and leave any further to persuade or attempt the said Tyndall to come into this realm,' inasmuch as 'his highness prudently considereth that if he were present, by all likelihood he would shortly (which God defend!) do as much as in him were to infect and corrupt the whole realm, to the great inquietation and hurt of the commonwealth of the same.'

Yet to these words, abandoning further efforts of persuasion, Crumwell added a postscript in the following somewhat inconsistent terms: 'Notwithstanding the premisses in my letter, if it were possible, by good and wholesome exhortations, to reconcile and convert the said Tyndall . . I doubt not but the king's highness would be much joyous of his conversion and amendment; and so, being converted, if then he would return into his realm . . . undoubtedly the king's royal majesty is so inclined to mercy, pity, and compassion, that he refuseth none which he seeth to submit themselves to the obedience and good order of the world.'

Vaughan exhibited this 'clause' or postscript to Tyndale, which of course really emanated from Henry himself, who was most desirous of drawing back Tyndale to his native land, but now only if ' converted.' The effect on the translator the agent described: "In these words I thought to be such sweetness and virtue as were able to pierce the hardest heart of the world; and as I thought, so it came to pass. For after sight thereof I perceived the man to be exceedingly altered, and to take the same very near unto his heart, in such wise that water stood in his eyes, and he answered: "What gracious words are these! I assure you," said he, "if it would stand 
with the king's most gracious pleasure to grant only a bare text of the Scripture to be put forth among his people, like as is put forth among the subjects of the emperor in these parts, and of other Christian princes, be it of the translation of what person soever shall please his majesty, I shall immediately make faithful promise never to write more, nor abide two days in these parts after the same; but immediately to repair into his realm, and there most humbly submit myself at the feet of his royal majesty, offering my body to suffer what pain or torture-yea, what death-his grace will, so that this be oltained,", etc.

This simple condition, thus nobly offered, Henry was unwilling to accept. One more interview followed, reported to Crumwell in a letter dated June 19, from Antwerp: "I have spoken with Tyndall, and showed him, as you wrote me the king's royal pleasure was; but I find him always singing one note.' Tyndale's 'one note - $-\mathrm{a}$ 'bare text' of God's Word to be allowed amongst the people-was as intolerable to Henry as 'conversion' back to Romish superstition was odious to the translator.

Soon afterwards Vaughan returned home by permission. But Sir Thomas Elyot, known as a scholar and a friend of More, described by Chapuys, from his worldly point of view, as ' a gentleman of seven hundred or eight hundred ducats of rent, formerly in the cardinal's service, now in that of the lady,' sent ambassador to Charles, September, 1531, was commissioned, besides the duties more strictly belonging to his embassy, to detect Tyndale in whatever lurking-place, and apprehend him outright. Nuch money was spent in acquiring intelligence, but all efforts were in vain.* The translator was ' moveable, like his wit.' Yaughan, on his return, was charged by More with being a 'fautor' of the Lutherans. In his defence he declared to Crumwell that he was neither a Lutheran nor a 'Tyndalyn,' but had been taught by Christ 'which is the Holy Scripture.'

At this period Antwerp was one of the asylums of Protestantism. Priests, monks, friars, who had repudiated

* See B. v., 869, 1617, and especially Elyot's letter of November 18, 1532, B. v., 1554. 
Rome, her falsehoods and superstitions, found there a refuge from the fangs and wiles of persecution. The Antwerp English house was well inclined to the Reformation; and Tyndale was the chosen chaplain of the merchants. Money, too, according to Sir Thomas More's statement, was transmitted from England for printing heretical books, which were imported thence into London, and cast abroad in the streets at night-to be taken up the next day by passengers, and perused at leisure. Thus Antwerp and London, commercially long since associated, were now drawn into yet more intimate relationship religiously. The great mercantile emporium on the Scheldt was the privileged scene of Tyndale's closing labours. His manner of life there has been briefly sketched by Foxe. Every Monday he would visit all such poor men and women as were fled out of England for conscience' sake. Every Saturday he would walk round about the environs of the town, and seek out his refugee countrymen in every corner and hole. These were his two days of pastime. 'The rest of the week he gave him wholly to his book.' When the Sunday came, 'then went he to some one merchant's chamber or other, whither came many other merchants : and unto them would he read some one parcel of Scripture, either out of the Old Testament or out of the New; the which proceeded so fruitfully, sweetly, and gently from him, much like to the writings of St. John the Evangelist-that it was a heavenly comfort and joy to the audience to hear him read the Scripture; and in likewise after dinner, he spent an hour in the aforesaid manner.'

But the endeavours of the Romanist party to inveigle John Fryth into their meshes met with complete success. Fryth had himself entered the controversial lists on the subject of purgatory against More, Rastell, and Fisher. He had dealt his adversaries some hard blows, treating More's 'poetical similitudes' as somewhat cheap pieces of painted glass, very easily shattered. Thus Vaughan had been directed to try his powers of persuasion also with Fryth, and induce him to return to England. A letter from Vaughan to the king conveyed the intelligence that 'Fryth was lately married in Holland.' 'Touching Fryth,' wrote Crumwell (May, 15:31), 
'the king laments that he should apply his learning in sowing the seeds of damnable heresies, ete. . . But he trusts that he is not so inrooted in these evil doctrines, but that by the graee of ( rod, and the exhortation of good people, he may be called to the right way. He therefore desires you to advise him to renounce his wilful opinions, and, like a good Christian, return into his native country, where he will find the king mercifully disposed." Vaughan, in reply, expressed his expectation that Fryth would shortly be in Antwerp, where he would not fail to 'approve' him by all possible means. $\dagger$

It was about July 25, 1532, aceording to Stokesley's register, that Fryth at length returned to England. His father was an innkeeper at Sevenoaks : but nothing is recorded of his son's movements until his appearance is notified at Reading. There were several members of the brotherhood at Reading. The mitred abbot of the great Benedictine monastery at this time was Hugh Cook, or Faringdon, a determined Romanist, who perished three years later, in the same cause as well as year, as the abbots of the great Benedictine houses of Glastonbury and Colchester. But the prior, John Shirbourne, was one of the 'brethren,' and, together with some others, had been already arrested and sent to the Tower.

At Reading Fryth was treated as a vagabond, and put into the stocks, and kept there until he was almost starved. At length, however, he obtained his release through the kind oftices of the schoolmaster of the town. This was Leonard Coxe, a friend and correspondent of Erasmus, $f$ and the author of the 'Art or Craft of Rhetoric,' printed 1524. Coxe was much pleased by the facility wherewith the culprit confined in the stocks conversed with him in Latin, and was delighted by Fryth's evideneing his aequaintance with Greek, by reciting some lines from the first book of Homer's Iliad. Set free from the stocks, Fryth used his best energies to escape from the dangers which hemmed him round, with as little delay as possible. He hid his head where and how he could. At one time he was in London among the faithful, met in a warehouse in Bow Lane; shortly afterwards he tried to

$$
\text { * B. v., } 248 .
$$$$
\text { † B. . ., } 311 .
$$ 
conceal himself among some of the affiliated congregations in the country. He found to his dismay, however, that he 'could be in safety in no place; no, not long among his friends.'

Sir Thomas More himself had obtained scent of the wandering heretic, in consequence of receiving, through a treacherous hand, a copy of a short treatise by Fryth on the "Sacrament of the Body and Blood of Christ.' This explanation of the topic especially in dispute had been composed at the request of an 'old familiar friend' - 'one who might better be a bishop,' said Fryth, 'than many that wear mitres, if the rule of St. Paul were regarded in their election.' 'Christ's body,' Fryth maintained, 'hath all the properties of our body, sin only except, and cannot be in two places at once.' 'It was not,' he wrote, 'the not believing Christ's bodily presence in the Sacrament that would damn,' but His 'absence out of the heart.' No heresy more rank could have been propounded, in More's judgment, than this. The bloodhounds of vengeance were at once let slip on the fugitive's track, and only for a short time was Fryth able to evade their pertinacious search. At Milton-shore, near Southend, just as he was hoping to embark in a merchant vessel, under the conduct of a friendly captain, which was seen in the offing, he was apprehended, and with as little delay as remorse sent a prisoner to the Tower.

There is a letter (October 21, 1532) from Sir Edmund Walsyngham, the lieuteriant of the Tower, to Crumwell, in reference to the heretics imprisoned under his charge. 'Two of them,' states Walsyngham, 'wear irons: Fryth wears none. Although he lacks irons, he lacks not wit nor pleasant tongue. His learning passes my judgment. As you said, it were great pity to lose him, if he may be reconciled.' Three days later, John Whalley, who seems to have been in authority over Crumwell's bricklayers and carpenters, besides apprising his master-who was at this time at Calais with the king and Anne Boleyn-that the house erecting for him in Austin Friars is 'going well forward,' and that four hundred men are at work on the king's buildings at the Tower, supplies information respecting the prisoners. 'The prior of Redyng, one 
of the prisoners at the Tower, was removed three days after you left, from Fryth and his fellows, to Beatcham Tower, accompanied with the parson of Hony Lane (Laurence Cook), and Christopher Coo, to be converted.'*

After Christmas, Fryth received, through a confidential channel, a letter from Tyndale, addressed to him as 'Brother Jacob.' The news of his imprisonment had not yet reached his friend. The early part of the letter is occupied with pastoral advice, to preach both the law and Christ, and to avoid unprofitable controversy. 'On the presence in the Sacrament, my mind is,' wrote Tyndale, 'that nothing be put forth till we hear how you shall have sped.' Then, after referring to the project of a general council, 'not of a pure heart, and for love of the truth, but to avenge themselves, and to eat the whore's flesh, and to suck the marrow of her bones,' Tyndale urges, 'cleave fast to the Rock of the help of God, and commit the end of all things to Him; and, if God shall call you, that you may then use the wisdom of the worldly, as far as you perceive the glory of God may come thereof, refuse it not, and ever among thrust in, that the scripture may be in the mother tongue, and learning set up in the universities.' Tyndale added emphatically, 'I call God to record, against the day we shall appear before our Lord Jesus, to give a reckoning of our doings, that I never altered one syllable of God's Word against my conscience, nor would this day, if all that is in the earth, whether it be pleasure, honour, or riches, might be given me. . . . God hath made me evil-favoured in this world, and without grace in the sight of men, speechless and rude, dull and slow-witted. Your part shall be to supply that lacketh in me: remembering, that as lowliness of heart shall make you high with God, even so meekness of words shall make you sink into the hearts of men,' etc.

Such are a few characteristic extracts from Tyndale's first

* See B. v., 1432,1407 ; vi., $934,943$.

When sherbourne had been ' converted,' Crumwell wrote to the abbot to reinstate him, who replied, 'I have received your letters concerning dan John Shirbourne, late prior of this house. And whereas you require that the said Shirbourne shall be restored, it will appear by his letter, herewith sent, that this is clean contrary to his mind.' 
letter, before he was as yet aware of his friend's apprehension and captivity. Sir Thomas Audley had succeeded Hore as lord chancellor (January 2(i, 15:3:3), as has been already said, eight months after his previous appointment to be keeper of the great seal. Other auspicious events for the progress of the reforming movement, such as the consecration of Cranmer to the primacy, had followed; and, under their combined influence, the rigour of Fryth's imprisonment became somewhat relaxed. He was visited in the Tower, and comforted by 'many faithful followers of Christ's Cospel,' and rejoiced to find that in the metropolis 'there was no small number walking in the ways of the Lord.' As he 'could not spin, and hated to be idle,' he composed in his durance several tracts, and resumed the controversy on Purgatory.

His arguments touching the body and. bloor of Christ in the Sacrament, written down, as has been said, for an esteemed Christian brother, had been obtained from this unsuspecting friend, under the pretence of real concern for the truth, by William Holt, foreman to Malte, the king's tailor. The tract had thus found its way into the hand of Sir Thomas More, in consequence of which Fryth had been tracked and arrested. Iore, however, not satisfied with seizing the person of an opponent, felt constrained to take up the pen and confute his arguments. He treated Fryth as a 'stripling,' deceived and led astray, rather than as a confirmed and matured heretic, such as he thought Tyndale. More's 'Letter,' however, against Fryth was circulated privately and cautiously; and it was only with much difficulty that 'one written copy' could be at length procured for perusal by the prisoner in the Tower. Its only importance to posterity lies in the fact that it proved the occasion of inducing the captive controvertialist to indite his celebrated and valuable 'Answer.'

In his teaching on the Lord's Supper, Fryth trod very much in the footprints of Zuingli, with whom, probably, he had conversed at the conference, and of whom he wrote, 'I think no man in Christendom might have compared with him.' Fryth's treatise must not be set side by side with the pulpit eloquence wherewith Tillotson discoursed on Tirnsul)stentiction, still less with the exact and elaborate investigation 
into the true doctrine of the Eucharist by Waterland. It preceded the earlier of these theologians by a century and a half, and under the pressure of the current ideas of the time was simply tentative and negative. It only maintained the temperate position that ' it is no article to be believed under pain of damnation that the Sacrament is the natural body of Christ.' It propounds three ends of the Sacrament: firstly, it serves as a badge or mark of Christians; secondly, it helps to imprint faith deeper, as clapping hands to a promise strengthens the assurance of the lips; and thirdly, it is a sacrifice of thanksgiving before the face of the congregation. But Fryth professed himself content with Luther's doctrine, and willing to leave the dispute between the Saxon and Swiss theologians an open question, just 'as whether Katharine be King Henry's wife or not.'

Fryth wrote under obvious disadvantages: 'Whensoever,' he said, 'I hear the keys ring at the doors, straight all must be conveyed out of the way; and then, if any notable thing had been in my mind, it was lost.' Shortly afterwards, however, on the severity of his confinement being relaxed, his keeper trusted to his 'word and promise,' and let him go at liberty during the night, to consult with good men. Thus, by persevering pains the work was completed. By secret means the 'Answer' was then conveyed to the Continent, and there printed. It is quite possible that the press may have been corrected by Tyndale himself.*

Its most memorable passage is a vindication of his friend and spiritual father from More's calumnies, who had called him a 'beast.' 'Tyndale, I trust, liveth well content with such a poor apostle's life as God gave his Son Christ, and his faithful ministers, in this world, which is not sure of so many mites as ye be yearly of pounds: although I am sure that, for his learning and judgment in Scripture, he were more worthy to be promoted than all the bishops in England.' After quoting the words of Tyndale's letter, wherein he declared his conscientious exactness, as Biblical translator, Fryth proceeded to state explicitly the one condition on which alone he and his friend had made up their minds to be silent for the future.

$$
\text { * See Tyndale's Works, P.S., iii., p. } 220 .
$$


' Until we see some means found, by the which a reasonable retormation may be had, and sufticient instruction for the poor commoners, I assure you I neither will nor can cease to speak; for the Word of God boileth in my body like a fervent fire, and will needs have issue, and breaketh out when occasion is given. But this that hath been offered you, is offered and shall be offered: Grant that the Word of God, I mean the text of Scripture, may go abroad in our English tongue as other nations have it in their tongues, and my brother William Tyndale and I have done, and will promise you to write no more. If you will not grant this condition, then will we be doing, while we have breath, and show in few words that the Scripture doth in many, and so at the least save some.'

A second letter was written by Tyndale, from Antwerp, about the middle of May, when he had now received accurate information of his friend's seizure and imprisonment.

'Dearly beloved, howsoever the matter be, commit yourself wholly and only unto your most loving Father and most kind Lord, and fear not men that threat, nor trust men that speak fair ; but trust Him that is true of promise, and able to make His Word good. Your cause is Christ's Gospel-a light that must be fed with the blood of faith. The lamp must be dressed and snuffed daily, and that oil poured in every evening and morning, that the light go not out. . . . .

'Dearly beloved, be of good courage, and comfort your soul with the hope of this high reward, and bear the image of Christ in your mortal body, that it may at His coming be made like to His immortal; and follow the example of all your other dear brethren, which chose to suffer in hope of a better resurrection. Keep your conscience pure and undetiled, and say against that nothing. Stick at necessary things; and remember the blasphemies of the enemies of Christ: "They find none but that will abjure, rather than suffer the extremity." Moreover, the death of them that come again, after they have once denied, though it be accepted with God and all that believe, yet is not glorious; for the hypocrites say, "He must needs die; denying helpeth not; but might it have holpen, they would have denied five hundred times; but seeing it would not help them, therefore of 
pure pride and malice together, they speak with their mouths that their conscience knoweth false." If you give yourself. cast yourself, yield yourself, commit yourself wholly and only to your loving Father, then shall His power be in you and make you strong; and that so strong, that you shall feel no pain, and that shall be to another present death; and His spirit shall speak in you, and teach you what to answer according to His promise. He shall set His truth by you wonderfully, and work for you above all that your heart can imagine. Yea, and you are not yet dead; though the hypocrites all, with all they can make, have sworn your death. Una salus victis nullam spereve sulutem. To look for no man's help, bringeth the help of God to them that seem to be overcome in the eyes of the hypocrites : yea, it shall make God to carry you through thick and thin for His truth's sake, in spite of all the enemies of His truth. There falleth not a hair, till His hour be corne; and when His hour is come, necessity carrieth us hence, though we be not willing. But if we be willing, then have we a reward and thanks.

' Fear not threatening, therefore, neither be orercome by sweet words, with which twain the hypocrites shall assail you. Neither let the persuasions of worldly wisdom bear rule in your heart; no, though they be your friends that counsel. Let Bilney be a warning to you. Let not their vizor beguile your eyes. Jet not your body faint. He that endureth to the end shall be saved. If the pain be above your strength, remember, "Whatsoever ye shall ask in My Name, I will give it you." And pray to your Father in that Name, and He will cease your pain or shorten it. The Lord of peace, of hope, and of faith be with you. Amen.

\section{' W'ililam Triddale.'}

There followed postscripts. The first expressed joy at martyr constancy at Antwerp, Riselles (Lille), Luke (Liège), Roan (Roten), and Paris, unto the great glory of the Gospel. Then the intelligence was communicated that George Joye had printed at Barrow (Bergen-op-\%oom) 'two leaves of Genesis in a great form,' and had sent 'one copy to the king and another to the new queen.' 'The tinal postscript 
was to this effect: "Sir, your wife is well content with the will of God, and would not for her sake have the glory of God hindered.'

But not satisfied with encouraging his 'beloved brother ' to patient endurance-now that Fryth had touched ' this terrible tragedy, and that the Eucharistic controversy had become uppermost-dismissing the reserve which he had previously recommended and practised, Tyndale took his stand deliberately by his imprisoned friend's side. He composed and published anonymously a treatise entitled, 'The Souper of the Lord.'* This treatise, short and pithy, was printed at Nornburg (Nuremberg ?) by Niclas Twonson, April 5, 15:33, as stated in its final colophon. That the treatise was really 'Tyndale's admits of little doubt. Besides, the internal evidence, the fact that it was published anonymously, and the author's name even studiously concealed, and that it was printed at a new place by a new printer, considering what Tyndale had declared on the duty of shunning controversy, may be held to serve as confirmatory proof. The treatise itself intimated that More would, without fail, recognise the author, 'Master Mocke, he knoweth me well enough;' and although More somewhat dissembled his knowledge, mentioning George Jay or Joy as perhaps the author, and in a letter to Crumwell styled it the work of 'an unknown heretic,' yet everywhere throughout his 'Answer' to the 'poisoned,' the 'Bedlam-ripe' book, the 'pontifical poet,' as Tyndale named More, was evidently aware perfectly that he was again hazarding a fall with his former redoubted antagonist. It is a 'book of that sort,' wrote More, ' that Fryth's book the brethren may now forbear.'

To eat the flesh and drink the blood of Christ, Tyndale averred, is to believe and know in the heart that Christ suffered death and shed His blood for us. Unlike Luther,

* 'The Souper of the Lord, wher-unto that thou mayst be the better prepared and verlyer instructed : have here firste the declarasion of the later part of the $6 \mathrm{ca}$. of St. Johã., beginninge at the letter $\mathrm{C}$. the fowerth line before the crosse, at these wordis: Verely, vere, etc., whereyn incidently M. More's letter agenst Joha. Fryth is confuted.'

Crosses marked the portions to be read in public service. Letters were used as now verses. Tyndale's first edition has neither.-Tyndale's Works, P.S., iii., p. 217. 
he connected John vi. with the Sacrament of the Lord's supper, explaining Christ's warning, 'the flesh profiteth nothing,' to be a rebuke to the Jews for putting a literal and carnal sense on words of spiritual import, and thus to be equivalent to the caution, "My Hesh protiteth you nothing at all to eat it.' Side by side with 'This is My body,' Tyndale placed the parallel passage, 'This cup is the New Testament,' the wine in the cup called a 'cup,' and the cup called a 'Testament.' He adduced Tertullian, Augustine, and a passage from a writing which he supposed to be Chrysostom's, in explanation that 'This is My body,' according to a very familiar mode of speech, means simply, 'This is the figure or sign of My body.' And he concluded with a brief account of the amended service, which he would fain have adopted, in order to the restoration of "the holy Sacrament unto the pure use, as the Apostles used it in their time.'*

More's 'Answer' to Tyndale quickly followed his 'Reply' to Fryth, the latter, for some reason or other, having been kept back from the public eye for more than a year. And the ingenious defence of Rome's absurd Thomastic sacramental system by her skilful champion, however inconclusive, closed the controversy at this juncture. The flames of Sinithfield were to accomplish what More's clever ' similitudes' were incompetent to effect.

The prospect that a life so full of promise as Fryth's might yet be spared had seemed, latterly at least, to brighten. His treatment had become less rigid. His genial social qualities added grace to his learning and talents, and won him personal friends. But he found a very determined toe in Gardiner, who had been his tutor at King's College, and who hated bitterly the enlightened religious tenets now plainly avowed by his former pupil. Gardiner examined him in December in his own house, and hoped to shake his constancy; but to his great annoyance found all his endeavours futile. To bring about his destruction was the only remaining plan that gave

* 'Tyndale's later work, "The Sacraments of Baptism and of the Body and Blood of Christ,' dwells prominently on the Hebrew custom of naming 'the memorial and signs of things with the very name of the thing signified.'-Tyndale's Works, P.S., i., pp. 346, 91. 
the remotest promise of the extirpation of his doctrines. It was certainly with Gardiner's countenance, and probably by his prompting, that Curwen, a court chaplain, preaching at Greenwich in maintenance of the new royal marriage, not only assailed the friars with harsh invectives, but also the opposing sect of those who impugned the established doctrine of the Church upon the Eucharist, and made unmistakable reference to Fryth. "There is one now in the Tower of London so bold as to write in defence of that heresy, and yet no man goeth about his reformation.' The hint was not lost upon the king, who not only as Defender of the Faith, but yet more, as now Supreme Head of the Church after God, deemed himself peculiarly called upon by his office to observe and punish any deviation from the orthodox creed, especially overt deviation from one of its most vital articles. It was resolved, therefore, that Fryth's case should be taken in hand without any further delay, and that the heretic should either be brought to recant, or, if obstinate, should undergo the extreme sentence of the Church.

Life sometimes teems with startling opposites-never more frequently so in England than in Henry's reign. The flames of the martyr's pile glinted back not only from the executioner's axe, but from the glittering pageant and merry festival. A letter from Cranmer (June 14, 1533) to Hawkins, his successor 'with the emperor's majesty,' briefly treated of the recent magnificent coronation of Anne, and then turned to the melancholy theme of Fryth's troubles. 'One Fryth,' be writes, ' who was imprisoned in the Tower, was appointed by the king to be examined by me, the bishops of London, and Winchester, Suffolk, the lord chancellor, and Wiltshire.'* This mixed commission of prelates and lay noblemen arrived at the conclusion that Fryth's tenet, that there is ' no corporeal presence of Christ in the host and Sacrament (after the example of (Ecolampadius) is notably erroneous.' They left the heretic, therefore, to be dealt with by his ordinary, the Bishop of London. By Stokesley he was condemned to death in St. Paul's (June 21) in the cant of the day, as 'not willing that thou who art wicked shouldst become more wicked, and

* See B. vi., 661, 682, 761. 
infect the Lord's flock with thy heresy: Andrew Hewet, a tailor, who shared his opinions, was condemned at the same time to share his fate.

Fryth now 'looked every day to go to the fire.' In his unhesitating firmness - the need of which in professing a Scriptural faith had been made doubly imperative by the cowardice of the brethren in the recent past, as he keenly felt-he refused to retract a single word or syllable of what he had written. To his answers in Latin to the interrogations of his judges he pointedly subscribed, 'I, John Fryth, thus do think; and as I think so have I said, written, defended and avowed, and in my books have published.' But his execution was yet deferred. Lively commiseration for one so young, learned and true-hearted, was excited in the breast of Cranmer himself, who in his deep compassion sent for him 'three or four times,' and laboured to persuade him to 'leave his opinion.' But all the archbishop's arguments and entreaties were in vain. Foxe's account of Fryth's journey on foot to Croydon under the conduct of Perlebean, the archbishop's gigantic porter, and a gentleman of his household, is among the best-known and the most interesting of the martyrologist's graphic narratives. 'At Bristow (Brixton) Causeway' his guides suggested that their prisoner should plunge into the wood which skirted their path, and then make his way into Kent, and find shelter among old friends and relatives. To Cranmer his escape would have been a sincere relief. But Fryth was resolute to present himself before the archbishop. He assured his guides that if they declined to escort him he should go singly without them, and was as fixed in his purpose to appear for trial as in his enlightened sacramental doctrine.

He was delivered over, therefore, to the mayor and sherift's, by whom he was consigned to a dungeon in Newgate. Here in darkness, his neck fastened to a post by an iron collar, so that he could neither sit nor stand upright, he contrived, by the light of a candle, to indite his last legacy to the Church of ('hrist-the 'Articles wherefore John Fryth died.' 'The cause of my death,' he wrote, ' is this: because I cannot in my conscience abjure and swcar that our prelates' opinion of the 
Sacrament-that is, that " the substance of bread and wine is verily changed into the flesh and blood of our Saviour Jesus Christ-is an undoubted article of the faith, necessary to be believed under pain of damnation.'

The execution was at Smithfield on July 4. Fryth embraced the stake for joy. He and his fellow-sufferer, Andrew Hewet, were fastened back to back. When the flames were driven by the wind from his own side of the stake towards his companion, Fryth expressed aloud his satisfaction that Hewet's release from agony would be more speedy than his own. Never had more triumphant courage - not even in the case of Hus at Constance-shone forth in the final anguish, or throughout all the stages of martyr endurance. 'Here in London,' wrote Carlo Capello to the Signory of Venice, "they have burned two heretics, one of whom was very learned in Latin, Greek, and Hebrew literature.'* Many lives afterwards, notably in the Marian persecution, 'gleamed into poetry at the stake,' but Fryth was the foremost typical Protestant martyr.

The crucial event in the early struggles of the English Reformation was thus reached in the heroic martyrdom of Fryth. His youth and promise, his abilities and learning, his piety and steadfastness, invested his cruel death with extraordinary interest. His execution was made the subject of remark in the House of Commons, and before the reforming Parliament was as yet dissolved-in the next session-an Act was passed whereby a suspected heretic was rescued from the gripe of the bishop, and placed at the bar of commissioners in open court. $\dagger$ The new Act noted significantly: 'It standeth not with right that any person should be convict and put to the loss of his life, good name, or goods, unless it were by due

* Ven., iv., 943.

$\dagger$ This Act ( 25 Henry VIII., c. 14) annulled the law (* Henry IV., c. 15) which bad lodged inordinate power with the diocesan, whom it had empowered to arrest, imprison, and canonically convict, and had required the sheriff to give implicit credence to his decision, so as to burn the heretic in a ' high place before the people.' But it confirmed i Richard II., Stat. 2, c. 5 , and 2 Henry V., Stat. 1, c. 7.

'The king,' wrote Chapuys to the emperor, 'has got Parliament to pass an Act, that henceforth no bishop or other clergyman shall act as judge in a case of heresy, etc.'-B. vii., 393 . 
accusation and witness.' And, further: 'It is not reasonable that any ordinary, by any suspicion conceived of his own fantasy, without due accusation or presentment, should put any subject of this realm in the infamy and slander of heresy.' Thenceforward it was required that the allegations should be proved by two witnesses; the verdict was to be pronounced by a jury, and the sentence was to be executed only on the king's writ. To speak against the Bishop of Rome was expressly declared to be no heresy.

Such an enactment witnessed to the great change which had been wrought in the convictions of the people. The malignity of the prelates drew back abashed before clear symptoms of general displeasure. Thenceforward no more bonfires of Testaments are recorded. On the advocates of a Scriptural creed Fryth's unwavering constancy exerted that encouraging influence which emanates always and only from consistent example.

Other circumstances boded well for religious reform. Despite differences of dogma, the king hinself, under the impulse of his position, was gravitating towards the adherents of a Scriptural creed. The hostility to the pope displayed itself in controversy; successive treatises were as so many missiles forged in the council, to be hurled by Henry at his rival in the Vatican. The antecedents of Clement were not forgotten. He was held up to contempt as a 'bastard and symonakre.'* In a tract, 'Concerning Royal and Priestly Authority,' it was even maintained that bishops simply are on an equality with other priests, except in precedence and in the honour showed them in church ; that kings and princes are their sovereigns. $\dagger$ The papists complained that now to object to the new royal marriage had become a worse crime than heresy. Anne herself was thoroughly whole-hearted on the side of Protestantism. Her influence was as yet still paramount, as was shown by Henry's grants and appointments-as, for instance, by the nomination of her brother George to be warden of the Cinque Ports. She and Crumwell and Cranmer were pillars of the rising cause. This was manifested very clearly a little later, when, in place of Campeggio, deposed from Salisbury, and of

$$
\text { * B. vii., } 115 .
$$$$
\dagger \text { B. vii., } 14 \text {. }
$$ 
Ghinucci, deposed from Worcester,* Shaxton-of whom it is noted that his daily prayer was that 'the clergy might be relieved of celibacy' - and the well-known Latimer were elevated to the vacant sees. In April, 1534, among Crumwell's 'Remembrances' the resolution is stated, 'To appoint preachers throughout the realm to preach the Gospel and true Word of God.' + In May preachers were warned not to 'wrest Scripture,' but to preach the words and deeds of Christ sincerely and simply. ${ }_{+}^{+}$Such decrees and such events marked decidedly that the tide had now turned, and Protestantism had a great future opened to it.\$ It was especially Fryth's unflinching endurance, consummating a pure and laborious career, which had rendered the success of the reforming doctrines a matter of moral certainty from that time forward. His logic derived force from his character. His ashes-that is, the writings which survived the flames which consumed his body-were among the principal means of opening the eyes of the chief among his judges, even Cranmer himself at a later perıd, to a more just conclusion on the central sacramental controversy.

Tyndale welcomed the news which was despatched to him from England with the triumphant joy of faith. Grief for the loss of his dearest son in Christ was swallowed up in devout thankfulness to God, who had enabled him to witness at a momentous crisis a good confession, without one thought of flinching. Tyndale was as Elisha when the chariot of fire and horses of fire had just snatched Elijah from his side. But in this case it was the Elijah himself, the elder witness, who was left a little longer in the tried post of testimony; it was the disciple and son who was first translated to his honoured rest. A quickened demand for the Word of God was one of the most blessed fruits of Fryth's faithfulness. Here was a call for

* In Crumwell's 'Remembrances,' early in 1534, occur the words: 'A Bill to be made for the king to take the bishoprics of Salisbury and Worcester into his own hands.'-B. vi., 50 .

Latimer's elevation was nearly coincident with the appearance of Calvin's 'Institutes' at Basle.

+ B. vii., 420 .

$\mp$ B. vii., 590 .

$\S$ Cranmer directed (November 11) that his style should be no longer A postolica sedis legatus, but simply Wetropolitamus.

In Convocation a petition was agreed upon for the translation of the Scriptures into English, although Tyndale's version remained under ban. -B. vii., 1555. 
renewed exertion, to which Tyndale responded with persevering alacrity, until he likewise, after a no long interval of three years and three months, finishing his course with equal heroism, was added to the noble army of martyrs.

The two Protestant martyrs, Tyndale and Fryth, stand forenost in elear apprehension of spiritual truths, as well as in personal eonsistency and faithfulness, amid the early efforts of the English Reformers of the sixteenth eentury. They were the real heroes of the movement at the period of its dawn. When many had discredited the cause by wavering timidity, they were the salt that renewed its vital energy. Thus, beyond any of their contemporaries, these were the instruments whereby Seriptural doctrine took root and flourished in the country of their birth. They wrote and toiled to the noblest ends before the various communions under the Protestant banner parted off from one another in England. To any division in the Protestant ranks they steadily opposed their best endeavours for unity. Thus they belong to the great undivided Reformed Church. Their memorials are constantly present with us. Tyndale's voice is still heard as often as the Word of God is read in the congregation. Our Anglican Church repeats after Fryth, in the Protestation annexed to the Office for the Administration of the Lord's Supper-the very gem of our Prayer-Book services permeated by his influencethat " the sacramental bread and wine remain still in their very natural substances, and therefore may not be adored (for that were idolatry to be abhorred of all Christians); and the natural body and blood of our Saviour Christ are in heaven, and not here: it being against the truth of Christ's natural body to be at one time in more places than one.'

Next to our Saxon Bible, the Prayer-Book of our Reformed Church deservedly takes rank. It is a companion book to our Bible in doctrine and in beanty. Like our Bible, the words of our Prayer-Book, although in habitual use, are still fresh, and do not pall upon the taste. Its devotional excellence is made perhaps most apparent by comparison-as when, for instance, on special oecasions, additional prayers of humiliation and supplication, or of thanksgiving, are inserted for a time. For the insertion, although the composition of 
minds of great ability and great piety, invariably shows much like a piece of very ordinary frieze stitched upon the finest cloth of gold. Studied verbal imitation only renders the essential discrepancy the more striking. Linked with these two invaluable books of our privileged Christian life in these modern days - books in continued use in our homes as well as in our churches - our two most enlightened and courageous champions in the early battles for an open vernacular Bible, to whom, under God, our Reformation in its vital spiritual aspect largely owes its triumph, still hold an abiding presence among us. 
BOOK VI.

MEDILVALISM PASSING. - WOLSEY'S LAST DAYS.

Mearwhile the curtain had already fallen on the fortunes and doings of the veteran statesman who may justly be regarded as the representative of that mediæval England which was now passing away, the ecclesiastical revolution drawing after it of necessity great civil changes. There was again some faint returning glimpse, however short-lived, to Wolsey of his former glory in a new and eomparatively humble sphere, accompanied, happily, with a genuine esteem such as he had never enjoyed in his palmy greatness. Then his light burnt down abruptly to the socket and expired.

To a work such as the present, which has endeavoured more especially to illustrate the characters of those associated with our nascent Reformation, whether as its champions or its opponents, a brief retrospect of the closing days of the ' king cardinal' in his humiliation will form a fitting conclusion.

A little after Candlemas (February 2), 15:30, Wolsey had been permitted to remove from his uncomfortable residence at Esher, which 'with continual use thereof waxed unsavoury,' and to take up his brief sojourn in the Lodge in Richmond Park. Here, observes Cavendish, there was 'a very proper garden, garnished with divers pleasant walks and alleys.' But in his new dwelling-place his proximity to the court proved no little offence to his 'hinderers and enemies,' especially to the jealous Norfolk. Directions therefore were conveyed to him to repair to his northern see. And when it 
appeared 'that he made no great haste' for the north, 'Tell him,' said Norfolk to Crumwell, ' that if he does not go shortly, rather than he should tarry here, I will tear him to pieces with my teeth.'

On hearing this characteristic threat, Wolsey remarked, 'Marry! Thomas, then it is time to be going, if my Lord of Norfolk take it so.' But lack of money continued an impediment. When the necessary supply had come, Wolsey removed in the beginning of Lent (Ash Wednesday in 1530 fell on February 24) from the Lodge into the Charterhouse of Richmond (Shene), which Dean Colet had made for himself for devotional retirement. By a secret gallery there was a communication with the Charterhouse Church. Every day Wolsey 'resorted' to the service, and spent the afternoons in 'godly contemplation,' and in converse with some of the ' ancient fathers,' who dissuaded him from the 'vainglory of this world,' and 'gave him divers shirts of hair, the which he often wore afterward.'

His progress northward began in Passion Week. His attendants were reduced to 160 in number, for several of his servants entreated to be allowed to 'tarry in the south, being loth to abandon their native country.' He and his diminished retinue proceeded by Hendon, the Rye House, Royston and Huntingdon, and so reached Peterborough. Here he spent Palm Sunday (April 10), and 'went in procession with the monks, bearing his palm right honourably.' On Maundy Thursday he 'made his Maundy in our Lady's Chapel,' washing, wiping and kissing the feet of fifty-nine poor men, being himself fifty-nine years of age. On Easter Day he 'rode in the morning to the Resurrection;' and that day, 'in his cardinal's vesture, with hat and hood, he sang the high Mass very devoutly.'

In his diocese of York he entered upon his archiepiscopal duties with an earnestness that was quite new to him. Aftability, meekness, sincere endeavour to promote peace and goodwill, pity and charity towards the poor, distinguished him. Now and then a gleam of his former self, especially of his old love of magnificent hospitality, broke through the humble routine of daily duties. It was no wonder that his altered 
life won him golden opinions with gentry and peasantry. His ambition had now taken a happier turn, and prompted him to set the example of a model bishop. It is reeorded of him during his stay at Southwell that he would travel most commonly every Sunday and holy day, 'if the weather did serve,' now to this parish chureh and now to that, and there would 'say his divine service, and either hear or say Mass himself, causing some one of his chaplains to preach to the people.' After service he would invite divers of the parish to share the dinner which he had brought with him; or he would dine at some honest house in the town, and afterwards would distribute 'a great alms.' 'W'olsey,' wrote Chapuys to the emperor, 'is leading a very devout life, saying mass daily, praising God for having aftorded him this opportunity of acknowledging his errors, and saying to everyone he meets that he never enjoyed greater peace of mind than at the present moment.'*

A similar transformation seemed to have passed over him as over Thomas becket, nearly four hundred years before, commonly referred to by contemporaries as his exemplarwhen the latter withdrew from the court, and betook himself to the care of his diocese and the service of the Chureh. His changed demeanour and mode of life in his new remote sphere were heard of by his friends in the metropolis, and weleomed with undisguised satisfaction. Amongst others, Crumwell addressed his personal congratulations: 'In mine opinion, your grace being as ye are, I suppose ye would not be as ye were, to win a hundred times as much as ever ye were possessed of.'

At Whitsuntide the palace at Southwell had undergone sufficient repair for Wolsey to be able to take up his residence therein. He removed, therefore, from the house of one of the prebendaries, his temporary sojourn, into his own palace, and remained there from June until the latter end of grease-time (the hunting season) - 'keeping,' says Cavendish, 'a noble table'-being 'visited by the chief persons of the country.' When he removed thence to Seroby (Scrooby), he was ' as much regretted at 'southwell as he was greeted at Seroby.' 
About the Feast of St. Michael, narrates Cavendish," 'he took his journey from Scroby towards ('awood Castle,' only about ten miles distant from York itself. On the road he lay 'two nights and a day' at St. Oswald's Priory of NostelCavendish's 'St. Oswald's Abbey.' Here he was the guest of Alvered (or Alured) Comyn, the twenty-ninth prior of the Augustinian house-a popular ecclesiastic, then in the sixth year of his oftice. In W ragby Church, built for the neighbourhood, and, although not dependent on the priory, yet served by the monks, which stands a stone's throw from the long stone granary, the only part of the ancient priory still remaining, $\dagger$ Wolsey was sedulously engaged in confirming children 'from eight in the morning until twelve of the clock at noon.' Making a 'short dinner,' he 'resorted again to the church at one of the clock,' and there 'began again to confirm more children until four of the clock.' At last he was constrained 'for weariness' to sit down in a chair, 'the number of children was such.' After this, he 'said his even-song, and went to supper, and rested him there all that night.'

Before the Reformation, it was the custom for the bishop to administer the rite of confirmation by repeating a form of words over the child in Latin, charming him, crossing him, anointing him with oil, and tying a linen band (generally the baptismal (hrisom) around the neck. $\ddagger$ Thus the rite, as then

* Cavendish's 'Wolsey' - as interesting as Roper's 'More' - was written in Mary's reign by George, the elder brother of William, the progenitor of the house of Devonshire. This biography, by the cardinal's gentleman usher, although without doubt seen by Shakspere, was not published until 1641 , and then ouly in a garbled form.

† Three years later Comyn built the church choir. See Banks' Walks about Wakefield,' pp. 274-279, and Hunter's 'South Yorkshire.' The priory was surrendered November 20 (31 Henry VIII.) by Robert Ferrar, or Farrer-put probably into the priorate for the purpose-afterwards' Bishop of St. David's (1548), and eventually, under Mary, a martyr.

It may be added that Comyu placed his own portrait in the east window, where now is the figure of St. Oswald, the genius loci from whom the wapentake - Osgood (Oswald)_Cross is named. St. Oswald's Cross, in old time, stood in the middle of Pontefract. The portrait of Comyn, bareheaded and kneeling, is now in a south window.

+ 'Becon's Prayers,' P.S., p. 234 .

Tyndale wrote: 'Yea, and of the very clout (the chrisom), which the bishop, or his chaplain, that standeth by, knitteth about children's necks at confirmation, what lay person dare be so bold as to unloose the knot?' -Works, P.S., i., p. 2:5. 
arlministered, required some little time and exertion. Yet the very next morning, ere he took his leave of the energetic prior, the cardinal was again strenuously engaged in confirming almost a hundred children more; and after this he 'rode on his journey.' As he proceeded, he found assembled at a stone cross, standing upon a green at Brotherton, just across the Aire from Ferrybridge, ' about the number of two hundred children,' who appeared gathered there, awaiting his archiepiscopal blessing. Alighting from his mule, he 'never removed his foot until he had confirmed them all;' and then, remounting his mule, he 'rorle to Cawood.'

York is rather less than ten miles distant from Cawood (Cavendish states the distance to be seven miles), and the archbishop's installation in the Minster, hitherto postponed from 'lack of money,' was now at length fixed to be solemnized on 'the next Monday after All-hallown Day.' The convocation was summoned to meet at York the same day. The request was addressed to Wolsey, and it was generally much desired, that he should consent to 'go upon cloth,' from St. James' Chapel, outside the eity gates, to his throne in the Minster. He replied with sober eircumspection: 'Although our predecessors went upon eloth right sumptuously, we do intend, God willing, to go from thence, without any such glory, in the vamps* of our hosen - - that is, barefoot. It was on bare feet that Adrian had entered St. Peter's, and so enkindled the enthusiastic admiration of all Christendom; and a prophecy had gained eireulation of a devoted pontiff who was to arise, 'named Angelo, who should go barefoot.' $†$

But meantime his enemies at Court, who received intelligence of the growing esteem in which he was held in the North, not without an increasing alarm for themselves in the somewhat rickety positions to which they had becn exalted by his fall, determined to build upon his doings and novel popularity an accusation of treasonable designs. A distinet

* Uppers-from the French arant pied.

$\uparrow$ 'This prophecy was applied to Cardinal Santa Croce, or St. Angelo, as he was commonly called-Francis Quiñones-whose earnest piety at liome was stigmatized as 'mania.' From a letter of Gardiner to Wolsey (January 31, 1529), it is plain that the superstitious archbishop had marked the prophecy. See 13. iv., part ii., 4977, 5014, 5237 . 
note of warning had been sounded by the faithful Crumwell, in a letter to his old master, despatched in August. "You are much bound to God, that you have obtained the good wishes of the people in those parts, and the report of it has augmented the good opinion of many towards you; yet notwithstanding, your charitable demeanour is misinterpreted here by your enemies. Yet follow all such things that shall stand best with the pleasure of God and the king. Some allege that your grace doth keep too great a house and family, and that ye are continually abuilding. For the love of God, therefore, have a respect, and refrain.' The buildings belonging to the See of York were in a very dilapidated condition. 'My houses,' in Wolsey's own words, 'be, by the oversight, despoil,' etc. That the complaint_- Ye are continually abuilding' - was founded upon fact, was due for the most part to the work of necessary repair, 'stopping holes,' and 'covering the houses above head against the weather.'* At Southwell, the palace had been found untenantable until repaired. At Cawood, however, the dilapidations were yet more extreme. Here, therefore, the decayed state of the ancient castle rendered repairs upon a far more extensive scale requisite, so that the cardinal had, according to Holinshed and Cavendish, in receipt of daily wages, as many as 'three hundred' workmen.

It is certainly interesting to catch this last glimpse of the great statesman, whilst still free, vigorous as ever amid his crumbling walls, occupied with toils such as had accompanied his progress through life. His career is illustrated in some sort by architectural achievements. Its morning is associated with the almost unique Magdalen Tower; its meridian with Hampton Court, where - although later Dutch taste has wrought a general metamorphose - yet the hall at least reflects Wolsey's grandeur of conception, his work being marked by that characteristic as much as by its mediaval character, and by the contrast of the different-looking material employed, the plum-coloured bricks. Associated, too, with the glories, some realized, more in contemplation, of Cardinal College, and with the sumptuous York Place, where the vestiges of his skill and taste have all been obliterated by * See B. iv., part iii., 6329, 6344, 64t7. 
fire. The evening twilight finds him active as ever, the early passion unabated, labouring to re-edify Cawood Castle, the gift, in a remote age, of Athelstane to the See of York. Of the time-worn building, looking down on the 'tawny Ouse' which eleaves with its placid waters the eity of York, very scanty ruins remain to us-only a gateway and a court-house. Amid such eongenial cares, a peaceful close to a life of turbulent ambition, the veteran statesman was surprised by the royal arrest, quickly followed by the supreme arrest.

There were traitorous spies in the cardinal's own household, who had a secret understanding with his jealous rivals at Court. One eertainly - probably more than one - in his employ, detailed his proceedings, and prognosticated his intentions to his envenomed foes. The principal traitor was unquestionably Dr. Augustine (Agostino), the Venetian physician. John Joachim de Taux, formerly a medium of eommunication between Wolsey and Louise, had now sueceeded 1) Bellay as French ambassador, and, although in the diplomatic service of France, was, it will be remembered, by birth a Genoese, and on terms of intimaey with J)r. Augustine. John Joachim had become estranged from the eardinal. $\mathrm{He}$ informed the Venetian ambassador (Venier) that, 'by the physician's own confession, the cardinal had solicited the pope at Rome to excommunicate the king,* and lay an interclict on his kingdom, unless he dismissed the lady.' Franeis, too, was changed in his sentiments towards Wolsey, and, contrary to his former partiality, preferred now the feebler statesmanship of Norfolk, whose assistance was less costly, and whose capacity was more on a level with his own. On a previous occasion Francis had sown suspicion of I'olsey's fidelity, by insinuating to Suffolk that, in a seeret eorrespondence with Clement, the cardinal had opposed the divoree. The motives for such an insinuation eannot be far to seek. No doubt the French monarch had reason to dread Wolsey's penetration and acuteness in negotiation, and his sineere derotedness to the real interests of England. Thus the accusation before made by Anne and her party was strength-

* See Chapuys' despatches to the emperor respecting 'Jehan Jocquin,' as he calls Giovauni Gioachino da Passano.-Sp., iv., 492, 509. 
ened and refurbished to serve as a decisive weapon for Wolsey's final ruin.

Was the fallen minister actually guilty of the double-dealing imputed to him? To this interesting inquiry it must be answered, that no sound evidence of the truth of the allegation, broached so persistently, has ever been forthcoming. But courtiers, who trembled for their own dignity and emoluments, were unscrupulous, and the surmises which they vented were turned into undoubted facts by their many adherents, and were circulated industriously. Consciousness of inferiority made the newly-promoted morbidly suspicious, and some wellremembered words of the king thoroughly stirred the raging tires of jealousy. In the council one day, when all had not gone according to his wish, Henry had exclaimed in a rage that the cardinal was 'a better man than any of them'repeating these words twice. 'I miss the Cardinal of York,' the perplexed monarch had blurted out with a sigh, when some puzzling question had protracted deliberation. There were those, too, who maintained that England had lost some measure of her weight in Europe since the experienced pilot laad been removed from the helm. The whisper circulated, that the lords of the council were really apprehensive that they would shortly be 'compelled to call for my lord cardinal's grace again.' The whisper reached Bonner, Wolsey's chaplain, and revived hopes not yet extinct. The cardinal had not abandoned himself to despair, but foolishly reposed trust in treacherous agents, who were quite unworthy of the least confidence. Thus, before he started for the North, he sent his physician, Dr. Augustine, on three several occasions to Chapuys-so, at least, the imperial ambassador declared *-to protter the discarded statesman's services to Charles.

That in the ferment of ambition such men as the two dukes should seize any available weapon to strike down their formidable rival, at once and for ever, may readily be imagined. They had weapons enough ready to their hand, supplied by Dr. Augustine's apt memory or fertile contrivance. His disclosures he wrote down 'with his own hand in a book, $†$ which

* sp., iv., 290 .

$\dagger$ Dr. Augustine received $£ 100$ for his treachery.

- A recognisance of Mr. Doctor de Augustinis, Venetian, in the sum of 
he presented to Norfolk, as president of the council. The cardinal, it appeared, had intrigued against Norfolk and suffolk, both in and out of England. He had conspired in various ways with his friends to regain his lost place. The rlukes hoped to poison effectually the royal inind against the old court favourite, and to this end had trumped up 'many important causes.' The cardinal, they stated, had a retinue of ' six hundred horsemen.' He fully believed, they said, that he was on the return road to his former influence and greatness. They were strong at the council board; Norfolk president, Suftolk vice.president. Anne, with unconcealed malice, vigorously abetted them, and with tears-so Chapuys relates-threatencd to leave the king, unless he yielded to their demand. Henry prayed her most affectionately-even weeping-that she would not speak of leaving him. But "nothing would satisfy her, except the arrest of the cardinal.' Thus Henry at length yielded his consent, that Wolsey should be put under arrest, and brought to examination, in order to elear his reputation-so the king professed to hope-from a host of calumnies.

It was accordingly committed by the council to Sir Walter Walshe, of the Privy Chamber-a go-between in Henry and Anne's love affair, who had now married Elizabeth, Sir William ('ompton's widow-and to the Earl of Northumberland, Warden of the Fast and Middle Marches, to proceed without delay to Cawood, and execute the warrant for the arrest. They arrived suddenly, the Friday (November 4) before the intended enthronement, which had been arranged to take place on the following Monday. When they abruptly entered the castle, Wolsey was at dimner, 'at his fruits.'

\&10), to be paid to the usc of our sovereign lord, etc., on condition that, it he keep secret all such matter as is mentioned in a book written with his own hand concerning the late Cardinal of York, and presented by him to my lord of Norfolk, president of the council, this recognisance shall be void ; otherwise it is to stand in full force. Hampton Court, December 11, 2.2 Henry VIII.-B. iv., part iii., 6763.

See, on the whole subject, B. iv., part iii., 6411, 6688, 6720, 6738; Sp., iv., 194, 49.2 ; Ven., iv., 51!1, 559!, 694.

Later, in 'Crumwell's Acconnts,' occurs the entry--June 28, 1,133:

"T'o Augustine de Augustynes, by way of reward, f100.'--B. vi.. 717.

Sub-equently Dr. Augustine fell into disgrace and under Norfolk's wrath, and craved Crumwell's kind offices.-B. vii., 5!9. 
The earl and his servants had been already in the hall some time, before the cardinal was aware of their presence; for, writes Cavendish, 'they had stopped the stairs that went up to my lord's chamber.' But at length one of the servants ' chanced to look down into the hall at a loop that was upon the stairs,' and returned with the tidings that Northurnberland was in the hall. Immediately the cardinal went down, and led the earl up to the chamber, where the dinner-table remained standing as it was. Then, giving his hand to Northumberland, he led him into his own bedehamber, where was a fire, 'to shift his apparel.' A short pause ensued, and then the earl, trembling, said-laying his hand at the same time upon Wolsey's arm-'My lord, I arrest you of high treason.' With affected composure the cardinal demanded, before he would surrender himself, to inspect the commission. This, however, as having a schedule with certain instructions annexed, it was necessary to keep back. Soon afterwards Walshe, who had been 'busy in arresting of Dr. Augustine,' the physician, at the door within the portal, "whom I heard saying unto him,' narrates Cavendish, " Go in there, traitor, or I shall make thee,", entered the apartment, and knelt to the cardinal. To him, as one of the privy chamber, and thus in himself a sufficient warrant without the commission, the cardinal surrendered. The keys of the castle were delivered over to Northumberland. Dr. Augustine, tied under a horse's belly, was promptly started on the road for London. In London he was lodged with Norfolk, by whom, as did not escape notice, he was 'treated like a prince.'*

Indescribable was the depression caused by this sudden arrest-quite overmatching Wolsey's fortitude. He well knew what it meant. A little afterwards, when left alone with Cavendish, he 'fell into such a woeful lamentation, with such rueful terms and watery eyes, that it would have caused the flintiest heart to have relented and burst for sorrow.' 'I am a true man,' he protested-'I am a true man.' Caventish knelt before him, essayed to instil comfort, and ventured to express the hope that, 'coming to his answer,' his master would so clear himself of all their 'feigned accusations' that

$$
\text { * B. iv., part iii., } 6738 \text {. }
$$


he would be restored to his "former dignity and estate." 'Tea,' replied Wolsey, 'if' I may eome to mine answer, I fear no man alive; for he liveth not upon the earth that shall look upon this faee'-pointing to his own-' and be able to aceuse me of any untruth.'

There was a short delay until the following Sunday (November 6), when the journey towards the metropolis began. The favour of the eountry people of the North remained with him to the last. They met him by thousands, as he journeyed, erying out with loud voice, 'God save your Grace! God save your Grace!' The route lay by Pontefract. Here the prisoner was lodged, not in the eastle, which would lave been of sinister omen*--but in St. John's Priory. The ruins of the once beautiful chureh appropriated to the priory still remain; and in their midst is now the parish ehureh, the aneient transept. Unroofed walls, mouldering window arehes, with delieate broken tracery, streteh on either side - white lines, looking like phantoms of the past. Thence the progress was to Joneaster, where the cavaleade rested for a night 'within the Blackfriars.' The next day they 'removed' to sheftield Park. Here their intention had been to repose for the third night under the hospitable roof of the Earl of Shrewsbury, and then at once to proceed on their route. But a longer rest was found to be necessary, for Wolsey had been seized with the flux (diarrhca), eaused proximately, it was said, by eating Warden pears. His illness was aggravated by unskilful treatment, and became so serious that a stay with shrewsbury for longer than a fortnight proved to be requisite. $†$

I)ring this interval sir William Kingston, Constable of the 'Tower, arrived with twenty-four men of the king's guard. Thus the rumour reeeived contirmation that Wolsey was to be escorted to the Tower to be lodged in the very chamber-so the people surmised, pleased to antieipate the hand of retribu-

* Wolsey exclaimed, 'Shall I go to the Castle. and lie there, and die like a beatst ?'- Singer's 'Cavendish,'i., p. 240.2.

†'The Itimary of Wolsey's last journey says, 'Sheffield Park, where lie continued eighteen days, ete.-Singer's 'Cavendish,' ii., p. 296.

It should be- where be continued till the eighteenth day from leaving Cawood. 
tive justice - which had witnessed the last hours of the ill-fated Buckingham.*

Wolsey was sitting at the upper end of the gallery upon a ' trussing (packing) chest,' his beads and staft' in his hand, when ' espying' Cavendish coming from the earl, he inquired:

'What news?'

'The best news that ever came to you, if your Grace can take it well.'

'I pray God it be,' answered Wolsey. 'What is it?'

'Forsooth, sir, my Lord of Shrewsbury, perceiving by your often communication that ye were always desirous to come before the king's majesty, and now as your most assured friend hath travailed so with his letters unto the king, that the king hath sent for you by Master Kingston and twenty-four of the guard to conduct you to his highness.'

By no means the least superstitious in that superstitious age was the 'foremost man in all the world' at that time as a statesman. Wolsey had been warned by a 'sorcerer' to beware of Kingston. He had shunned the town. But now, somewhat like Henry IV., who had found the Jerusalem of his doom, not in the holy eity, but in a chamber at Westminster, so Wolsey trembled before a flesh and blood Kingston. Repeating the name aloud twice or thrice, and 'clapping his hand on his thigh,' he heaved ' a great sigh.' It was to no purpose that Cavendish strove to cheer him, and assured him that the ling was his very good friend, and intended to hear his cause himselï, and even now had sent some of the cardinal's old attached servants-men formerly amongst his yeomen, to protect him on his road. 'I perceive,' answered Wolsey, 'more than you can imagine or can know; experience of old has taught me.'

Kingston was introduced, and, according to the fashion, knelt down to the cardinal. 'I pray you stand up,' exclaimed IVolsey; ' kneel not unto a very wretch, replete with misery'

* Wolsey's malevolence seems to have tracked even the son's course. At luast, Henry Stafford complained to the king of having been compelled by my lord cardinal to 'break up his household' ; and, having no titting dweling-place on the lands given him by the king, to 'board at an abtey this four years' day with his wife and seven children.'-B. iv., part iii., 6123. 
stand up, or I will myself kneel down to you.' In vain did Kingston essay all his skill to console him by insisting on the genuine goodwill which the king bore to his former minister, and the absolute necessity of the examination in order to purge his character from grievous imputations. From these, added he, you will easily set your reputation free. 'Alas!' retorted Wolsey, "these comfortable words are only to bring me into a fool's paradise. I know what is provided for me. Notwithstanding, I thank you, and will be ready to-morrow.'

During the night the malady had passed into a more eritical stage. ${ }^{*}$ Tet-after another day's interval-on Thursday, Norember 24, the journey was resumed. Weak though he was with the continued dysentery, so that he could searcely sit upright upon his mule, he yet succeeded in reaching Hardwick-upon-Line (Notts) that day; and the next day he was able to ride as far as Nottingham. Saturday (November 26) the venerable walls of the Augustinian Abbey of St. Mary de Pratis, Leicester, revealed themselves in dim outline. This was an abbey of some importance, $\dagger$ situate nearly a mile to the north of the town. It proved the goal of his wearisome journey. Night was ereeping on before the abbey was at length approached. In the dusk the abbot and all the brethren of the convent eame forth to weleome the cardinal ' with the light of many torches.' To their reverent greeting, Wolsey answered simply: 'Father Abbot, I am come to leave my bones among you.' Kingston took him by the arm, and lifted him up the stairs. Glad was he, after his fatigue and sufferings, to be placed in bed, and to obtain some rest. But, writes Cavendish, he 'grew sicker and sicker.'

His life was now to be measured by hours. It is noteworthy that, amid the weakness and faintness preceding death, he exhibited no little eoncern for his reputation as a

* 'His new disease... caused him still continually from time to time to go to the stool all that night; insomuch from the time that his disease took him unto the next day, he had above fifty stools. . . The matter that he voided was wondrous black,' etc.-Singer's 'Cavendish,' i., p. 310 .

† Its revenues, according to Dugdale, were 951 li. $14 \mathrm{~s}$. 05d.'-'Monasticon Anglicanum' (folio), p. 1041 . 
man of truth and fidelity. Scarpinello, the Milanese ambassador, in a despatch to the Duke of Milan, stated that the cardinal, in his anxiety to impress the constable and his guards with his innocence, had as many as the chamber would hold summoned into his presence, and then, raising himself in his bed with some effort, said to them: 'I received my Maker yesterday, and I pray God that sacrament may be to the damnation of my soul if ever I thought to do dis. service to my lking.'*

Monday, the day before his death, the support of food being essentially needful, he swallowed a spoonfui or two of what the cook had prepared; and then, learning it was ' a cullis made of a chicken,' he instantly exclaimed: 'Why, it is a fast day !' and no entreaty could prevail upon him to take a spoonful more.

What a scene the chamber of the dying cardinal presents, when, at seven o'clock the next morning (Tuesday, November 29), Kingston stands by his bedside: the arrogant, haughty favourite, who had been wont to be so inexpressibly 'lofty and sour ' towards the overbearing feudal aristocracy of the time when they thwarted him, now himself disgraced and prostrate, death on his sunken face, and the gaunt captain of the guard, the very sight of whom made many tremble, leaning over his dying bed! 'Master Kingston, if it chance you to be one of the king's privy council, as for your wisdom and other qualities ye are meet to be, I warn you to be well advised and assured what matter ye put in his head, for ye shall never put it out again. I assure you I have often kneeled in his privy chamber on my knees the space of a hour or two, to persuade him from his will and appetite; but I could never bring to pass to dissuade him therefrom.' Better known are the words: "Naster Kingston, I see the matter against me, how it is framed; but if I had served my God as diligently as I have done the king, He would not have given nuc over in my gray hairs.' $\dagger$ With faltering voice he urged:

* Ven., iv., 637 .

$\dagger$ Shakspere makes Wolsey address such words to Crumuell:

'O Cromwell, Cromwell!

Had I but serv'd my God with half the zeal

I serv'd my king, He would not in mine age

Have left me naked to mine enemies.' 
'I request his Grace to have a vigilant eye to depress this new sect of Lutherans ;' and then, with tremulous effort he essayed to enlarge, according to Cavendish, on the heinous mischief of heresy, and the danger of popular mobs.

Earlier in the morning he had been in close confession, for 'the space of an hour,' with Dr. Palmes, his chaplain. And now, as death was, without fail, near at hand, Abbot Richard (Pexall)* was summoned to 'anneal' + him. As the clock struck eight, 'incontinent,' in fulfilment of his own prediction uttered to Cavendish-' by eight of the clock ye shall lose your master' - he 'gave up the ghost.' + Cavendish and those standing about his bed, as they marked his departure, looked one upon another, remembering his words.

Immediately Kingston sent a yeoman of the guard 'empost' to the king, but resolved on no account to postpone the funeral. The corpse in the hair shirt, which Wolsey had been accustomed to wear next, the skin, was placed in a rude coftin of rough boards, and lay in state, with mitre, cross, and ring, in the archiepiscopal robes. In the afternoon, between four and five o'clock, the corpse was carried to the church, and set in the lady Chapel, and torch watch was kept, 'the canons singing Dirige, and other devout orisons,' until four o'clock in the morning. Then Mass was sung, and the interment took place. Two hours later Kingston, Cavendish,

* From Bishop Longland's injunctions to the well-known Abbey at Leicester, in 1532, we gather that the Abbot had not said Mass in the church for three years. . . that he too, like the prior of Walsingham, kept a fool (scurra), who marched at the head of the canons when they went to chapel, etc.-Church Quarterly Review, Art. vii., January, 1890.

$\uparrow$ Administer extreme unction-

'Cut off e'en in the blossom of mv sins,

Unhousel'd, disappointed, unanel'd,'

moans the Ghost in 'Hamlet.'

+ 'The Cardinal of York,' wrote Chapuys, 'died on St. Andrew's Day, at a place where Richard was killed. They are both in the same chureh, which the people call " the Tyrants' Sepulchre.",

Wolsey, however, really died St. Andrew's Eve, November 29, 1530; and lichard III. was buricd in the Church of the Franciscans, not of the Angustinians.

Dr. Angustine assured Granville, June, 1531, that Wolsey had not been poisoned. Sce B. iv., part iii., 6757 ; Ven., 283 ; Singer's 'Cavendish,' i., 1. 3.25.

Brewer ascribes Wolsey's death to 'fright.' 
and the rest took horse for Hampton Court. 'I had liever,' exclaimed Henry, on receiving the intelligence, 'than twenty thousand pounds, that he had lived.' Anne, on her part, with her characteristic sincerity, did not affect to conceal her thorough satisfaction. By no means, however, does it raise our estimate of her, or of her father, that, according to a despatch of the imperial ambassador,* daughter and father signalized the event by a supper, "when there was played a farce of the going of the cardinal to hell.'

So died, and so was interred, the once all-powerful 'kingcardinal,' the 'haughtiest man in all proceedings that then lived,' so long, at least, as fortune smiled on him. With human shortsightedness, he was accustomed to keep by him the sum of $£ 1,500$-enormous for that age--in preparation for his obsequies. His possession of this sum was notified to Henry by Northumberland, and excited the monarch's lively curiosity, so that he directed Kingston to make inquiries, and afterwards himself personally questioned Cavendish. Wolsey's monument, to be erected in Cardinal College, in connection with an altar, had been in course of execution for some years. It is thus quite in consonance with fact that Shakspere has placed in the cardinal's mouth an anticipation of the period when he should 'sleep in dull cold marble.' The tomb was the work of Benedict, the Florentine sculptor, who was proud to assert, in his 'simplicity,' $\dagger$ that it would surpass the monument of Henry VII. 'twofold or more in costliness, art, and beauty.'

'Alas!' commented Erasmus, 'the slippery turns of this world!' Instead of lavish magnificence, and all the pomp of

* See Chapuys' despatch, B. v., 62.

+ See Benedict's letter, January, 1529, B. iv., part iii., 5743. Benedict had been employed on the tomb since June, 1524 .

'The king intends it to serve for himself, post multos et felices ammos, having caused the cardinal's arms to be erased from it.'-Letter of Augustino Scarpinello, Ven., iv., 637.

There is an entry in the 'Priry Expences,' December 30, 1530 : 'To Mr. Cromwell, for the king's tomb, $£ 13$ 6s. 8d.'-B. v., p. 753.

The tomb was reserved for a nobler guest. The bones of England's greatest admiral sleep there. One who was in later years Dean and historian of St. Paul's, witnessed as a boy the interment, and seemed to hear a suppressed wail from the blue-jackets as Nelson's remains were laid in the marble.-Milman's 'St. Paul's.' 
death, the burial was almost indecently mean and hasty. And seven years later the abbey itself was suppressed; the hand of violence rushed to the spoil, and no reeord remains to us of the spot where repose the bones of perhaps the greatest of English statesmen. Even the site of the burial-ground is now unknown; and every vestige of the chapel itself has long since disappeared.* Tet the burial of Wolsey, with however little eeremony, and however hurried, was the burial of an ex-lord-chancellor, who had been at the same time also archbishop, cardinal, and papal legate; of the last and immeasurably the most extraordinary of a long line of distinguished prelate-statesmen; the burial of a system, and not only of an individual.

* Near where the Abbey once stood now moulder some ruins of a mansion erected by the house of Devonshire, partly with materials from the old monastery. Only a portion of the high wall, which formerly enclosed the domain-now a park for the people-and a gateway, under which the cardinal, it is said, made his last ride, survive in record of the past. 


\section{APPENDIX.}

Bоок III., Сн. II.

John Skelton, much praised by Erasmus, classical tutor to Henry, poet-laureate, and Rector of Diss, has amusingly sketched the clergy of his time in his vivacious doggerel. Skelton is compared to Jonathan Swift, but was the better man of the two. His life was not so rough as his verse. He was a concubinary priest, but regarded his concubine as his wife. It was the fault of the Church, he said, that they were not married. His name occurs among the commissions of the peace for Norfolk, March, 1531 (B. v., 166, 12). Mention is made in Crumwell's 'Remembrances ' of the 'Jestes of Skelton' (B. vii., 923). In his 'Boke of Colin Clout' it is especially that he paints the clergy of his day with racy vigour-their

\section{Igxoraxce.}

'And how when ye geve orders

In your provincial borders,

As insipientes,

Some are insufficientes,

Some parum sapientes,

Some nihil intelligentes,

Some valde negligentes,

Some nullum sensum habentes,

But bestially and untaught.

But whan they have once caught

Dominus robiscum by the hed,

Than renne they in evere stede

God wot with dronken nolles,

Yet take cure of sonles,

And woteth never what they rede,

Pater noster nor Crede,

Construe not worth a whistle,

Neither Gosjel nor Pistle,

Theyr mattins madly sayde,

Nothing devoutly praid, 
Their learning is so small,

Their prymcs and houres fal, And lepe out of their lippes,

Lyke sawdust or dry ehippes.

I speke not now of al,

But the most parte in general.

A priest without a letter,

Without his vertue be greater,

Doubtlesse were much better,

Epon him for to take

A mattocke or a rake.

Alas for very shame,

Some cannot deelyne their name,

Some camnot scarsly rede.

And yet will not drede

For to kepe a cure,

And nothing is sure,

This Iomine cobiscum,

As wyse a Tom a thrum,

A chaplayne of truste,

Layth all in the duste.'

\section{SIMONY}

"What hath laymen to doe,

The gray goose for to shoe,

Like houndes of hell,

They ery and they yell,

How that ye sell

The grace of the Holy Gost,

Thus they make their bost

Through every cost.

Men say for sylver and golde

Miters are bought and solde,

There shall no elergy appose

A myter nor a crosse,

But a full purse.

A straw for Goddes curse,

For a simoniake,

Is but a hermoniake,

And no more ye make

Of symony men say

But a ehilde's play.'

\section{LeCHerY.}

'I speake not of the god wife But of their apostles life.

Cum ipsis vel illis

Qui manent in villis,

Est uxor vel ancilla,

Welcome Jacke and Gilla, 
My prety Petronylli, And you will be stilla, You shall have your willa. of such pater noster pekes, All the worlde speakes.'

Neglect of Preaciing.

'For if ye wolde take payne

To preache a worde or twayne, Though it were never so playne, With clauses two or three, So as they mighte be Compendiously convered, Those wordes should be more weid And better perceived, And thankfully receyved, And better shoulde remayne Amonge the people playne, That wolde your wordes retayne, And reherse them agayne, Than a thousand thousand other, The blaber, barke and blother, And make a Walshman's hose Of the text and the glose.'

Tine Begging Friars' Cunnixi.

'Now will I goe, And tell of other moe, Semper protestando De non impuguando The foure orders of fryers,

Though some of them be lyers, As limiters at large Wyll charge and discharge, As many a fryar God wot Preaches for his grote, Flattering for a new cote, And for to have hys fees, Some to gather cheese, Lothe they are to lese Eyther corne or mault, Sometime a bacon flicke, That is three fingers thycke, of larde and of greace

'Their covent to encrease.'

\section{Tile Nurs.}

'And the selfe same game Begon and now with shame Amongsest the sely nunnes My lady now she runnes, Dame sybly our abbesse, Dame Dorothe and lady Besse, 
Dame Sare our pryoresse, Out of their cloyster and quere, With an heavy cheere, Must cast up their black vayles, What Colin there thou shailes, Yet thus with yll hayles, The lay people rayles.'

$*$

$$
\text { * * * * }
$$

'Over this the forsayd laye Report how the Pope maye A holy anker call Out of the stony wall, And him a bysshop make If he on him dare take To kepe so hard a rule, To ryde upon a mule, With golde all be trapped, In purple and paule be lapped, Some hatted and some capped, Rychely be wrapped, God wot to theyr great paynes, In rotchettes of fine reynes, White as morowes mylk

Their tabertes of fine silke, Their stirops of mixt golde begarded, Their may no cost be spared, Their moyks* gold doth eate, Theyr neighbours dye for meat.' Skelton's 'Boke of Colin Clout' : Chalmers' ' English Poets.'

* Domestics- $\delta \mu \tilde{u} \epsilon \varsigma$, whence Skelton coined $\delta \mu \omega i \kappa o i ́$. 


\section{NE EX.}

Abeer of St. Mary de Pratis, Leicester, 364

Abelard, 81

Absenteeism, 15

Academy, Florentine, 23, 30

Adelstone (Athelstant), King, 58

Adrian V I., 159, 161

Adrocation, papal, 218, 219

Albans, St., Abbey, 47, 238, 266

Albigenes, the, 264

Alexander VI, 5

Amboise, Cardinal d', 44, 48, 155

Ain-s, Mr., si

Anien:, treaty of, 182

A'npthill, 294

Anderson, Cliristopher, $64,68,83,88$, 89

Angelo, Cardinal Santa Croce, 189, 356

Annates, 16 ; Act in restraint of, 296

'Answer,' Fryth's, to More, on the Eacharist, 339, 340, 341.

'Answer,' More's, to Tyudale's 'Souper of the Lord,' 34.4

'Answer,' Tyndale's, 141

Antwerp, 7\%, 8s, 105, 129, 172, 314, 334,335

Apparel, 18, 19

Appeal to it General Council, Henry's, 306,307

Appeals to Rome, Act against, 305

A juinas, Thomas, $32,46,181$

Ariosto, 6

Armada, Spanish, 301

Arthur, Prince of Wales, 151, 152, 209

Arthur, Thomas, 38, 43, 93

'Articles' against Wolsey, 248, 249

Arundel, Archbisbop, 77

Ascue, Anne, 138

'Assertio VII. Sacramentorum,' 159, 160
Attainder, Bill or Act of, $2.5,287$

Audaie (Aude) river, 2.2:3

Aulley, Sir T., 213, 247, 286, 296, 299, 339

Angustine, Dr., 25:2, 358.361

Augustine, St., $3: 3$

Bacon, Francis, 41, 122, 131 Roger, 12

Bainham, James, 329

Bucelona, treaty of, $22: 3,224$

Burlow, Jerome, 111, 112

—. Joln, 111, 195, 269

Barnes, Robert, 32, 92, 93, 110, 12), 121,141

Barrow (Bergen-op-Zoom), 329

Bartelonmen, Fra, 29

Bartm, Elizabeth, the Nun of Kent, $25,257,300$

Basle, 37, 125, 16

Bayar 1 , 164, 171

Baytield, Richard, 43, 321

Becket, Thomas, 32, 45, 3.1

Becon, Cranmer's chaplain, :38, 11

Berdminster, 108

Bedyll, Richard, 15

Bellay, John du, bishop and ambassador, $205,213,217,22 \times, 260,358$

Bembo, Cardinal, 6

Benedictine monks, 12

Bengel, 88

Berengar, 84

Berkeley, baron $<$ of, $57-59$

Bermard, St., 188

Bible, our Saxm, 318

Biblemen, 7, 75

Bilney, Thomas, $39 \cdot 40,93,32: 3 \cdot 325$

Blackfriars, 211, 241

Blount, Bessie, 180, ״43

Blunt, Professor, 41 
Bohemia, 247

Bolern, Anne, s8, s9, 105, 119, 179, $184.186,192,197.200,204,213,236$, $239,254,261,291,293,306,308,337$, $318,366,867$

Boleyn, George, 155, 255, 292

- Sir Thomas, created Lord Rochford ; afterwards Earl of Wiltshire, $184,186,267,269,367$

Bologna, 269, 278

Bommer, Dr. Edmund, afterwards bishop, 233, 254, 262, 306, 359

Borgia, Ciesatr, 5

- Lncretia, 5

Bosworth Field, 8, 301

Bourbon, Charles, Duke of, 161-164, $173,1 \% 4$

Brandom, Charles, Duke of siuffolk, 220, $221,231,232,257$

Brentford, 1tis

Brethren, the, $76,97,107,110,841$

Brewer, Professor, 184, 218, 2:30, 254, 268

Brief, papal, 209-212

Bristol, 69, 109

Bruger, 77

Bryan, Sir Francis, 200, 227

Buckden, near Huntingdon, 293

Buckenham, Prior, 319, 320

Buckingham, Edward Stafford, Duke of, 233,246

Bucklersbury, 128

Budé (Burlieus), 2.2

Bull, papal, 36, 160, 188, 209

Burnet, Gilbert, bishop, 1, 10, 207

Bury St. Eitmunds, 4:

'Burying of the Mass,' 112

Busche (Buschius), Herman von, 115

Butts, William, M.D., 204, 252, 321

Byrchman, Arnold, 83

Caistor Castle, 17

Calatis, 291

Cambray, treaty of, $2221-2 \cdot 24$

Cambridge, 39,41

Campano, 21:2

Camphell, Lord, 46, 136, 260

Campergio, Lawrence, Cardinal, 50, $157,203-205,207,208,212,218-220$, $225,206,347$

Canterbury, 32

Capello, Caslo, 316

Capon, 1)r., 52, 94

Cardinal of Anema, 278

- of Osma, 279

Irchbishop of Ravenna, 278

St. Quatuor, Pucci Lorenzo, 190, 212

- Santa Croce, Quiñones Francis, $189.350^{\circ}$
Carey, William, 204

Carthusian monks, 29

Casale, Gregory, 190, 191, 210

Cavendish, George, $177,179,221,237$, $253,256,350,352,357,361,363$, 366,367

Cawood Castle, 358

Caxton, 22, 59, 15:

Celibacy, 2, $1: 33$

Cellar, Salt-fish, Oxford, 104, 109, 110

Cervia, 221

Chancellor, Lord, 49, 238, 239

Chancery, the Court of, 49, 242, 243

Chancery, the Roman, 8

Chapel, Lincoln College, 108

Chapuys, Eustace, 120, 2:34, 235, 239, $241,249,271,272,275,283,284$, $288,293,29 \pi, 300,301,309,327$, $332,352,359$

Charles V., the Emperor, 156, 157, $159,161,171,206,207,222-224,230$, $269-271,291,297,300,301,315,332$

Charles VII. of France, 155

Charles VIII. of France, 155

Charnock, Richard, 31, 32

Chaucer, Geoffrey, 19, 113

Chelsea, 124

— Manor-house, 124, 137. 186

'Chri-tmas, the still,' 91

Chrysostom, St., 2I

Church, the 141,142

-_, the Anglican, 3, 275

—, the Roman, 2

__ All-hallows, Honey Lane, 105

$\longrightarrow$, Chelsea, 145

__ Our Lady's, at Antwerp, 129

_., St. Adtine's, 63

—. St. Dunstan's in the West, 73

- St. Stephen's, Coleman Street, 75

Churchmen, Broad, 34

' Citatorial letters,' 225

Civita Vecchia, 213

Clarenciens, king-at-arms, 175, 176

Clement VII., Julio de' Medici, 67,161 , $169,173-175,185.190,212,221,223$, $304-308$

Clergy, benefit of, 7.9

Clerk, John, Bishop of Bath, 205, 209 , canon, 53, $107-109$

Coehlieus, John (1)obneck), 79, 8., 90

Cognac, Alliance of, 169

Colet, Jolu, 263, 30, 32-35, 47, 131

- Sir John, 27

'Colin Clout,' 11:2

College, Cardinal, Oxford, 35, 51, 235

- I pswich, 35, 52

_, Gumwell (Gonville), Cambridge, $10 \%$

Henry VIII.'s, 51

Magdalen, Oxford, 59 
College, St. John's, Cambridge, 36

- Trinity (St. Cuthbert's Hall), Oxford, 12

Cologne, 79, 80, 83, 85

'Colloquies,' Erasmus's, 13, 32, 127, 129

Colonna, Pompeo, 174

Colporteurs, 19, 97-99

Columbus, 22

Commission Decretal, 208, 212, 214

Commission, papal, 191

Compton, Sir William, 200, 204

Comyn, Alured, 355

Concubinage of priests, 11 and Appen. dix.

Confession, 14, 131 ; Katharine's, 208

'Confutation,' More's, 144

Constantinople, capture of, 21

Constantyne, George, 86, 137

$\longrightarrow$, vicar, 99

Convent of Wilton, 202

Convocation, 26, 68, 77, 245, 258, 272, $292,293,295,321,356$

Cook (or Faringdon), Hugh, 335

Copernicus, 22

Cottisford, Dr., 106-108

Council, the, 239, 286, 287, 347

Coverdale, Miles, 39, 93, 313

Coxe, Leonard, 335

Cranbrooke, 96

Cranmer, 'Thomas, 43, 59, 199, 266:274, $293,294,307,327,345,346,349$

Cresacre, Amne, 124

Crome, Dr. Edward, 323, 324

Crumwell, Gregory, 273

Crumwell, Thomas, 13, 249, 253-255, $266,273,274,286,299,300,309,331$, $332,336,341,347,349,353,351,357$

Curwen, Dr. Richard, 345

Dalaber, Anthony, 52, 53, 106, 107, 110

Dante, 11, 84, 264

Darey, Lord, 248

Darey, Thomas, Lord, 248

D'Aubigué, the historian, 322

Dauncey (or Datuntesey), William, 124

Dean, Archbishop, 16

Death, the Black, 54

'Defender of the Faith,' title of, 160

Jemaus, R., 55, 147, 314

De' MIelici, the, 29

Democitus, 12.;

Denton, Dr., 58

Deu!z, 81

'Dialogue,' More's, 139

Dionysius, the Areopagite, 30

Dispensation, papal, 192

Dominic Guzman, St., 11

Dominicans, the, 214

Dorset, Marquis of, 45

'Douceurs,' 15
Duns Seotus, John, 39

Dunstable, 293, 294

Dunstan, Anthony, Prior, 107

Easterlings, 93

Ech, John Meyer, 90

Editions of Erasmus's Greek Testa. ment, 81

Editions of 'Tyndale's Pentateuch, 314

Editions of Tyndale's Version, octavo, 85- 87

Editions of Tyndale's Version, 'puarto, ete., $87-89$

Edward III., 96, 239

Edward IV., 63, 118, 158, 200, 244

Elbe, the river, 80

Eleanor, WVilliam Carey's sister, 202

- wife of Henry II., 188

Elizabeth, 'the Good,' wife of Henry VII., 153, 154

Elizabeth, Queen, 307

Eltham, 91

Elyot, Sir Thomas, 273, 333

'Enchiridion,' Erasmus's, 66, 67, 78

Erasmus, Desiderins, 4, 25, 30.33, 36, $37,61,66,115,127-129,131,194$, $226,239,299,311,367$

Esher (or Awher), 237, 252

'Estates, the three,' 245

Euripides, 33

' Expectative graces,' 16

Falier, Lodovico, 217

Fastolf, Sir John, 17

Fanst, 85

Ferdinand, King of Aragon, 151, 152, $156,15 \%, 190$

Ficino, Narsilio, 29, 30

Field, John, 137

'Field of the Cloth of Gold,' 158

Fisher, John, Bishop, 36, 49, 93, 101, $147,160,209,210,218,216,247$, $285,292,295,300$

Fitz.James, Richard, Bishop, 27, 36, 71

FitzRalph, Richard, Archbishop, 1:

Fitzroy, Harry, 180, 231, 260, 312

Flemings, the, $77,96,97$

Florence, 22, 29

Forman, Robert, 10:5

Fox, Dr. Edward, 266, 267

Fox, Richard, bishop, 46, 47, 152, 158

Foxe, the martyrologist, $39,42,43,51$, $60,65,79,262,263,314,335$

Francis I., 157, 158, 163, 164, 169, 170, $171,175,232,276,253,291,292,306$, $307,35 \mathrm{~s}$

Francis Bernardone, St., 11

Frederic, Elector of Saxiny, 115

Freeman, the historian, 4

Irendoberg, George, 173, 174 
F'rideswide's, St., 51, 107, 108

Fromde, the historian, 12, 110, 184, 321

Fry, Francis, 315,317

Fryth, John, 62, 76, 119-123, 141, 313, 333-349

Finsey, 44

Fyshe, Simon, 98

Gainsford, Mrs., 119

Gambara, prothonotary, 190

Gardintr, Dr. Stephen, 50, 103, 206, $211,215,221,233,234,251,253$, $260,266,267,271,293,295,297,302$, 344,345

Garrat, Thomas, $105-108,110$

Gasquet, Francis Aidan, 13, 256

Ghinucci, Jerume de, 67, 190, 210, 347

Gifford, br., si

Giugrs, Margaret, 124

Gigli, Sylvestro de, 67

(Xiles, Peter (Petrus Egidius), 129

Gilford, Sir Harry, 71

(iloncestershire, is

(roch, John of, 6

Goodale, John, 105

(rospellers, the, 91

Goulhurst, 96

(rongh, John, 104, 105

Grafton, 227

('rammar, Linacre's, 24

— of sit. Paul's Sehool, 25,26

Grammar Schnols, 23

Grammont, (rabriel, Bishop of Tarbes, 153

Gravelines, 158

Green, the historian, 137

—, St. Anstin's, 69

Greenwich, 308

Grocyn, William, 24, 25, 29, 30, 33

(irositute, Robert, 12

Guinegate, or the spurs, battle of, 18 , 155

Gimmel, Mr., 21

Gumpowder, invention of, 17

Gutenbergr, 85

IIacker, John, 75

Hales, Chuistopher, 229

Hall, Wlward, the chronicler, 6S, 176, $217,242,247,296$

Hall, Canterbury, 12

—_, Clare, 39

Gloucester (now Worcester

College), 12

I Iall, Macrdalen, 59

- . St. Mlban's, 106, 107

II allam, the historian, 21, 35, 113, 135

Hamburg, 77.80

H'mse Towns, League of, 77

Harman, Richard, 86, 98, 105
Harpsfield, Nicholas, 127

Hebilthwayte, William, 7:2

Henry, Grace de J)ieu, 48

Henry II., 188

Henry III. (Jimperor), 6

Hemry IV., 363

Henry VI., S, 244

Henry VII., 15, 46, 153

Henry VIII., 8, 10, 81, 119, 126, 134, $154,155,171,175,176,187,190-$ $192,206,207,210,211,213,217$. $220,223,230.233,235,241,244$, $246,249-256,275 \cdot 278,280-254,286$, $289,291-300,305-309,311,312,318$, $320,321,359,367$

Heron, Giles, 124

Hervey, Lord Arthm, bishop, 317

Hewet, Andrew, 345

Higden, Ramulph, 59

Higdon, Johm, 108, 109

Hiidebrand, ('regory VII., 2, 51

IIIldegard, Abbess, 84

Holbein, I1 ans, 126, 184

Holinshed, Raphael, 91, 215, 217, 357

Holt, Nicholas, 25

Hook, Dean, 74, 245, 262

Horsey, Chancellor of London, 9, 10

ILotel, Bull, at Cambridge, 41

Howard, Hemry, Lord Surrey, 195, 234

_. Lady Elizabeth, 184 folk.

Hugh, St., Bishop of Lincoln, 12

Humme, Richard, 9

I1mut's Court, 55

Hus, John, 75

IIutten, Uhric von, 115

liythloday, Rathael, 129

Iamblichu×, 30

Impeachment, Parliamentary, 247,243

Indulgences, 16

Inmocent III., 51, 301

Innocent VIII, 5

'Instrumentum novuri,' 129

Iona, 50

Irish, the, 302

Isabella of Castile, 151-15:3, 190

_- Empress, 168

I imes, St., Epistle, 75

. Teamne, of France, $20 \mathrm{~s}$

Jerome, St., 32

Jews, the, 78

Joachim, Abbot, 84

- Johin de Passano, sieur de Vaux,

$163,165,230,358$

.John, Kine, 301

'Tomall,' Tyndale's version, 316,317

.Jordan, Isabella, 202 
. Joye (or .Jay), George, 88, 94, 136, 137, 314,341

Juana of Castile, 208

Julius II., 5, 153, 265

Karne (or Carne), Sir Edw., 282

Katharine, Queen, 151-154, 180, 183, $191,197,203-210,215-218,225,279$. $281,287-284,293,294$

Kempe, 77

Kingston, Sir William, 362-366

Knight, Samuel, D.D., the biographer, 23,27

Knight, William, LL.D., Henry's secretary, 189, I90

Lambert, John, 43

- Francis, 106, 115

Lannoy, Charles de, 162, 164, 172

Latimer, Hugh, (bishop, 1535), 14, 15, $27,40,91,92,94,95,110,311-324$, 326,347

Latymer, William, 25, 68

Lautree, Odet de Foix, 161, 206

League, Holy, 155, 156

$\longrightarrow$, Italian, 169

Lee, Edward (afterwards archbishop), $15,79,90,160,182,207,210,236$, 288,292

Lee, Roland (afterwards bishop), 292

Legate, Papal, 47

Lempereur, Martin, 88

Leo I., 6

Leo IX., Bruno, 6

Leo X., 5, 6, 161

Leonora, Dowager of Portugal, 169, $171,222,223$

'Letter' or 'Reply' against Fryth, More's, 339, 344

Leyva, Antonio de, 164, 172

Lily, Dionysia, 26 , WVilliam, 25

Limmington Rectory, 45

Linacre, Thomas, 24, 30

Little Sodbury, court, 63, 64

Loan, amicable, 167, 168

Lollards, 7, 27, 74, 75 Tower, 9, 104

Lombards, the, 77

London, the city of, 110

$\longrightarrow$, Dr. John, 13, 107, 108

Longland, John, bishop of Lincoln, 96, $104,108,109,183,293$

Louis VII. (the Young), 188

Louis XI., 155, 161

Louis XII., 156, 187, 188

Louise, mother of Francis I., 161, 163, $171,222,317$

Louvain, 39, 129

Luft, Hans, 115, 313, 314
Luther, Martin, 3, 7, 55, 66, 75, 81, 82, $84,85,90-92,121-134,159,201,313$, 344

Macaulay, Lord, 263

Machiavelli, 29, 264

Mackintosh, Sir James, 144

Madrid, treaty of, 169,222

Mai, Miguel, 219, 278, 279

Maitland, Dr., 78, 104

Manor-house, Chelsea, 124

Marburg, 114, 119 ; conference at, 121, 122,224

Margaret, the Lady Dowager of Savoy, $46,77,172,221,222,2 \cdot 26,317,318$

Margaret, widow of Charles the Buld, 317

Marguerite, sister of Francis I., 187, $198,22 \cdot 2$

Marignano, battle of, $15 \%, 158$

Mary of Burgundy, 157

Mary, Princess, 154, 167, 17 1, 177, 288, 289,310

Masters, Ricbard, 285

Matthew and Mark, $79,83,86$

Maximilian, 156, 157

Medici, the, 224

__, Juliano de', 161

_- Julio de'. See Clement VII.

—, Katharine de', 205

- Lorenzo de', 161

Meghen, Peter, 27

Melanchthon, Philip, 40, 76, 81

Memorial, More's, 146, 147

- Tyndale's, 55

Mendoza, Inigo de, lishop, 178, 2:34

Middleton, Alouisa, 125

Milan, 161, 16:3

Milton, John, 23, 144

Milton-shore, 336

Monasteries, 12-14, 168

Monastery, St. Frideswi le's, 51

- Witt nberg, 132

Montjoy, Lord, 31

'More, the,' 266

More, Alice, dame, 125

- Cresacre, 243

_-_, Jane, 124

—, John, 121

—, Sir John, 136

_-, Sir Thomas, 27-29, 79, 128-147, $159,160,186,200,221,238,241$. $243,259,285,256,298.300,313,314$, $318,326,229,337,339,344$

Iorice, Ralph, Cranmer's secretary, 273

Morone, $17: 2$

Morton, Cardinal, 28

Mountjoye, William Blount, Lord, 216, 295

Mumpsimuses, 63 
Munmouth, Humphrey, $70,72,73,76-79$

Muraty, Johu, 87

Nluseun, Britisb, $87,8 \mathrm{~s}$ -, FitzWilliam, 4.2

Mytha, lersian god, 130

Nanfan, Sir John, 46

Navarre, King of, 187

Necton, Robert, 98

Neo-Platonism, 30, 37

New leaming, the, 2s, 36, 132-134

Nibley Kinoll, 5i, 147

- - , North, 55

Nixe, Richard, bishop, 102, 103, 326, $329,3: 30$

Numinalists, the, 35

Norfolk, Thomas, second Duke of, 47 , $146,156,206,230,232,233.239$, $242,248,257,283,287,353,360$

Norris, Hemry, 227, 237, 255

Northumberland, tiftl Earl of, 185,186

'Novum Instrumentum,' 129

Nun of Kent. See Elizabuth Barton.

Nuremberg, 270, 341 ; peace of, 270

'Olnedience,' Tyndale's, 117, 119, 139, 245

(Ecolampadius, 87

offor, (reorge, $5 \mathrm{~s}, 62$

Olderstle, Sir John (Lord Coblam), 7 , 74

Orliteto, 189,195

Orleans, Duke of (afterwards Henry II.), 223,306

Ortiz, 1)r., 301

()sborne, Mr., si

Osiander (Hoseman), Andrew, $2 \% 0$

Ostiit, 213

Oxford, $2 \cdot 2$

- - Lord, $\mathrm{S}_{7}$

Pace, Richarel, 125, 131

Packington, Anguntine, 314, 315

1'itlutes, 1)r., sijti

Palserave, John, 180, 248

Paper, linen, invented, 18

'I'araphrases,' Erasmus's, 129

Pardons, Buston, 205

P'arker, Chancellor, 67,68

Pauler, Mattlew, afterwals archlisbop, 327

Parlitment, 241, 243-245, 219,250, 296

P'arynge, Lord Chancellor, 239

'Panton Letters,' 17, 74

Pattenden, or Patteson, IIenry, 1:26

P'ululet, Sir Amyas, 45

Patul's, St., 93, 131

- Cross, 100, 101

Pavia, 16:3, 164

lecock, lieginald, i
Pellicanus, 56

'Pentateuch,' Tyndale's version, 315 , 316

Peohebla, Dr. (Puebla), 152, 211

Percy, Henry, afterwards sixth Earl of Northumberland, 185, 265, 360, 367

Perlebean, 345

Pescara, Marquis of, 161, 172

Peter-pence, 305

Petition, Parliamentary, 244, 245, 259, 296,297

Peto, William, provincial of the Observants, 284,310

Philip, Landgrave of Hesse, 121, 122

Pico della Mirandola, 28, 29, 138

Piers Plowman, the vision of, 16,113

Pius 111., 5

Plato, $23,37,128$

Plotinus, 30

Pluralities, 15

Poggio, 21

Pole, John de la, Duke of Suffolk, 152

- Cardinal, 133, 235, 257

Politian, 29

Pollicitation, papal, 214

Polychronicon, 59

Pontefract, 4, 362

'Practice of Prelates,' Tyndale's, 120, 310-313

Pratt, Louis de Flandre de, 164-166

Premunire, Statute of (16 Rich. 1I., c. 5), 17,257 ; offences against, 229

'Praise of Folly,' or 'Murice Enconimu,' 129

Prat, Anthony du, 161

Prelates, unpreaching, 15

Printing, invention of, 18

Proclamation, royal, $31 \bar{\tau}, 31 \mathrm{~s}$

Proclus, 30

'Prologues,' 115, 116

Protestants, the, 197, 224, 283

Provisur:, Statute of, 17

Purvey, John, it

Putney, 2:37

Quadrivium, the, 59

Quentel, P'eter, 83, 115

Raffaello, 6

Ravenna, 221

Reading, 3855

Realists, the, 35

Reed, Thomas, 326 ;

lienee, daughter of Louis XI1., 187

Reservations, 16

'lievixions' of Tyudale's version, 86,87

Rhine, the river, 80

Richard $111 ., 171$

Richardes, Griffin (or Richard (iryffyth), 216,295 
Richmond Park, 352

Ridley, Robert, 100

Ridolpho, Campegrio's son, 187

Rincke, Herman, 85

Ritwyss, John, 25

Rivers, Earl, 17

Robertson, the historian, 164, 170

Rode, Mr., 37

Rome, sack of, 173-175

Roper, Margaret, 124-126

$\longrightarrow$, William, 124-126, 132

Roye, William, 73, 83, 85, 99

Rudiments, Colet's, 35

Rinpert, Abbot, 84

Russell, Sir John, 240, 254, 255

Ryce, Griffith ap, 179

Sacerdotalism, 2, 3, 10

Sadler, Ralph, 254

Salisbury, Lady, 235

- use of, 316

Salviati, Jacobo, Clement's secretary, $21 S$

Sampson, Richard, dean of the Chapel Koyal, 119

Savonarola, 29

Sichaeffer, Peter, 85

Schism, the great, 5

Scholasticism, 4, 23, 33

Schools, grammar, 23

- St. Anthonyn's, 25

- Stepney, 27

—_, St. Paul's, 83

Schott, John, 103, 112

Scriptures, the, prombited, 4 ; wrested, 64

Seal, the great, 48,238

Selling, 24

Sexten, the fool, 238

Sforza, 169

Shakspere, $45,216,227$

Shaxton, Nicholas, afterwards bishop, 347

Shaxton, Nicholas (bishop in 1535), 349

Shirbourne, John, $336^{\circ}$

Shrewsbury, Earl of, 248,362

Sickness, the sweating, 91

Sigismund, lapal secretary, 211 and Appendix.

Skelton, John, 112, Appendix

Sliubridge, 55

'Souper of the Lord,' the, Tyndale's, 343

Sisuthwell, 352

Spain, 301, 302

Spalatin, 115

Spiers, Jiet of, 121, 221

Spurs, Battle of the, $4 \mathrm{~S}$

Staffeléo, bishop, 183
Stafford, Elward, Tnke of Burkingham. Siee 'Buckingham.'

Stafford, (reorge, :38, :3!), 41

Standish, Henry, bishop, Guardian of the Cordeliers, 9, 99

Star Chamber, 134, 2:3!

Statute, Carlisle, 16: Liveries, 18; Provisors, 17 : Premunire, 1 $\vec{\imath}, 2.29$

Stepney, 27

Stillyard, men of the, 93

Stinchcombe, 55

Stokesley, John, bishop, 56, 57. ti, $104,137,235,345$

Submission of the clergy, $297,29 \mathrm{~S}$

Subsidy, book of the, 295

Succes-ion, Act of, 308

Siffolk, Duke of, $220,221,231,23 \cdot 2$, $236,239,248,257,345,360$

Suicide, 131

Supremacy, the Popes, 34

- , the Royal, 17, 245, 295, 307 ; Act of, 309

\section{Tauler, 7}

Tennyson, 184

Testament, the English, s1-83, s5, S7-89, 9-100, 102, 103, 106

Testament, Erasmus's edition, 31, 64, 78, 81, 107

Thames, the river, 38,80

Theology, 60

Throgmorten, Sir George, 193

Tiptoft, John, 17

Tisen, John, 61

Tittenhanger, Herts, 2:38, 2006

'Tower, the Lollards', 9, 104

$\longrightarrow$ Magdalen, 35

Tracy, William (of Toddington), 68, 59 , 323

Trevisa, John de, 59

Trivium, the, 59

Trojans (nicknome), 35

Tudor, Mary, French Queen, 156, 186

Tuke, Sir Brian, 228

Tunstal. Cuthbert, hishop, 25, 61, 7.2. $91,93,97,100,103,104,110,12: 3$, $221,235,296$

Tyndale, Edward, 57

—., John, 57

- - Martin, 57,61

_- Thomas, 58

- Willim, or Huchins, 4, 31. 4ti, $55-82,85-89,113-148,183,198,245$, $305-317,332-334,33 \vec{i}-342,34 \overline{7}, 345$

Urban VI., 5

Urbino, Duke of, 172175

Usher, Geoffrey, 105

'Utopia,' the, 3.5, 129-131

Utopus, Prince, 130 
Vanity Fair, 18, 19

Vannea, Peter, 220

Vaughan, Stephen, 120, 111, 271, 331-3:4, 335, 386

Vaux, John Joachim de Passano de. See 'Joachim.'

Veuality, 15, 16

Version of Scripture, Anthorized, 143 Revised, 143, 144

Tyndale's, 75, 85-87, 141-143,

317; Tyndale's Pentateuch, 314, 315

Version of Scripture, Wycliffe's, 74, 75

Vespucci, Amerigo, 29

Vitelli, Cornelio, 24

Vitrier, Jehan, 56

Voysey, John, bishop, 102

Vulgate, the, $37,59,75,82$

Wakfelde, Richard, 182

Walsh, Lady, $63,66,67$ , Nlaurice, 62

Sir John, $62,66,67,71$

Walshe, Sir Walter, 360,361

Walsingham, Sir Edmund, $3: 7$

Warbeck, Perkin, 152

Warham, William, archbi*hop, 26, 33, $47-50,102,103,110,209,271,295$

Warner, Dr., 325, 327

Warwick, son of Clarence, 152

Wayneflete, William, 59

Webb, Richard, 65

Welsh, the, 302

Wesel, John of, 6
Wessel, Jobn, 7

West, Nicholas, bishop, 91, 92, 95

Westcott, bishop, 82, 88, 115, 314

West Kington, 321, 322

Whalley, .John, 336

Whinchelcombe, Abbot of, 9

White Horse (or Germany), 42

'Wicked Mammon,' Tyudale's, 115

Williams, or Patch, 238

Winter, Tom, 47, 235, 254

Wittenberg, 80,81

Wolsey, Thomas, 15. 34, 44-54, 76, $92.95,100,104,108-110,119.160$, $161,165 \cdot 167,171,176,177,183,184$, $18 \overline{7}, 190,191,202,203,213,215,220$, $221,224,236,240,242,247.257,279$, $285,311,312,350,352-368$

Wool, 96, 301

Wootton-under-Edge, 55

Worms, $80,85,87,114$

Wriothesley, Thomas, 138

Wyatt, George, 110, 185 , Sir Thomas, 185, 234

Wycliffe, John, 5, 9, 12, 74, 75, 77, 97, 145

Ximenes, Cardinal, 44, 51

York, Archbishopric of, 253 , House of, 7

Place, 236, 238, 250, 298

Zwingli, Ulric, 55, 120, 237, 339

THE EN1). 



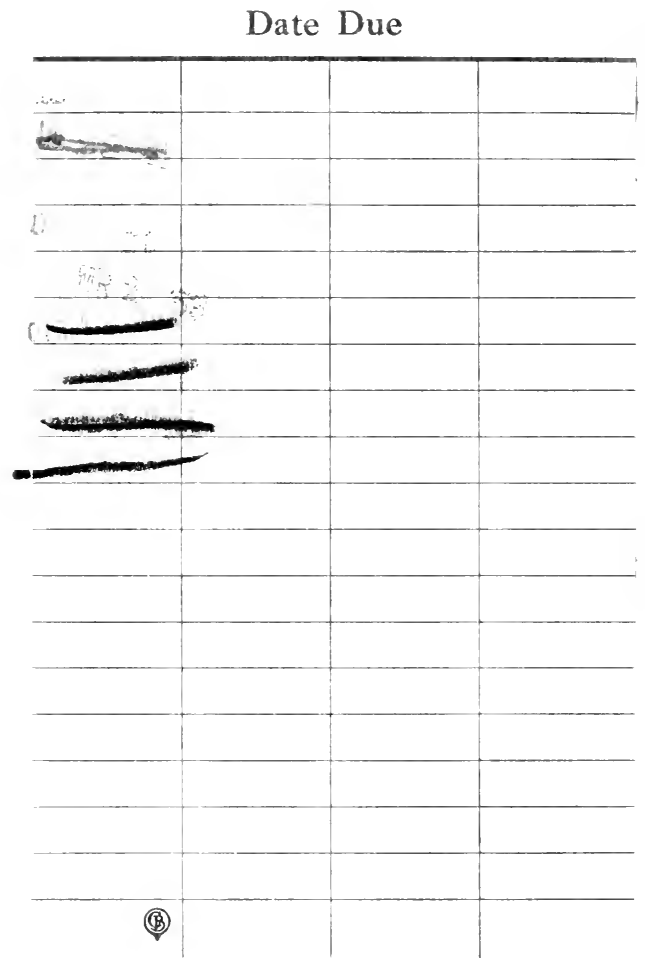





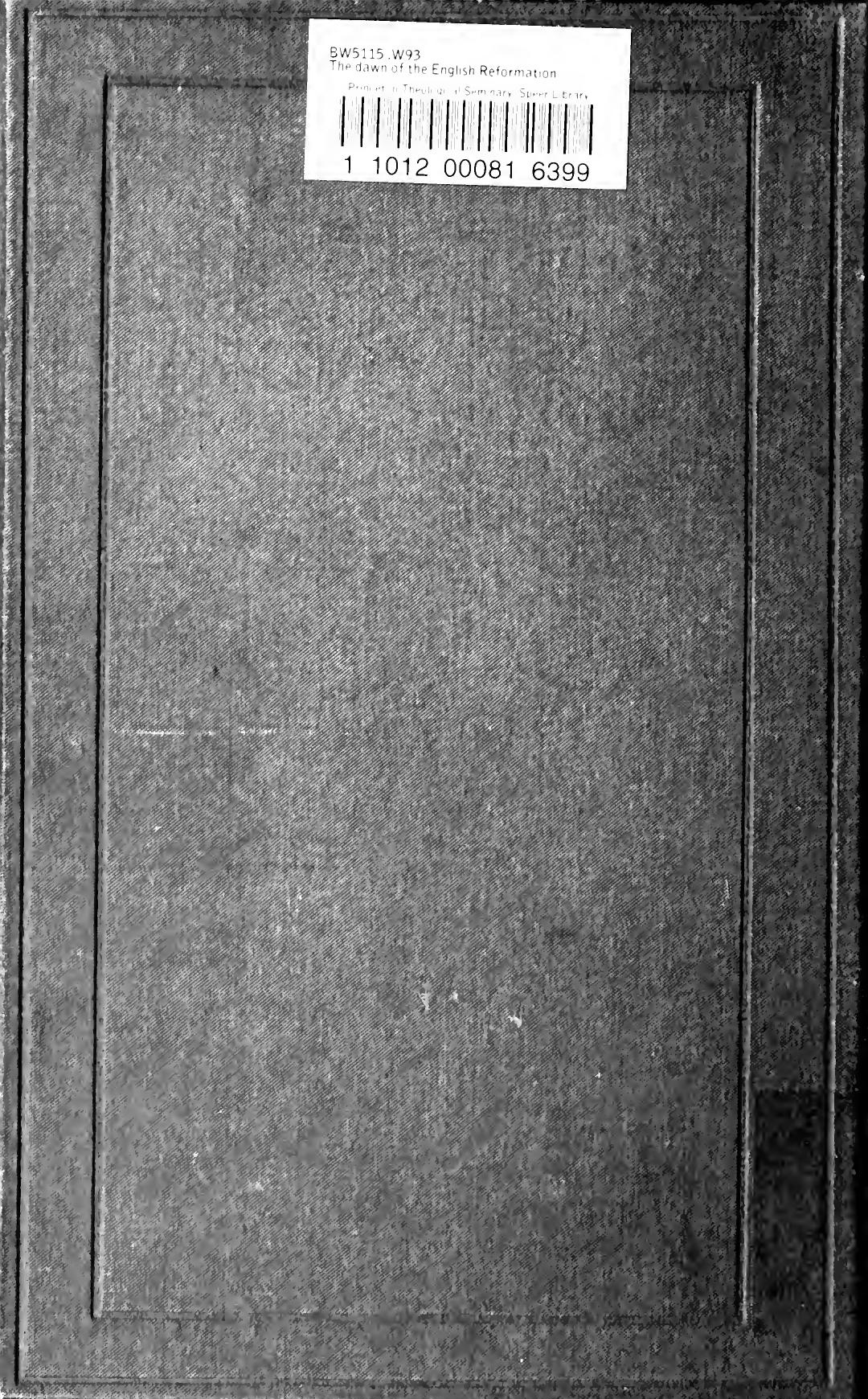

